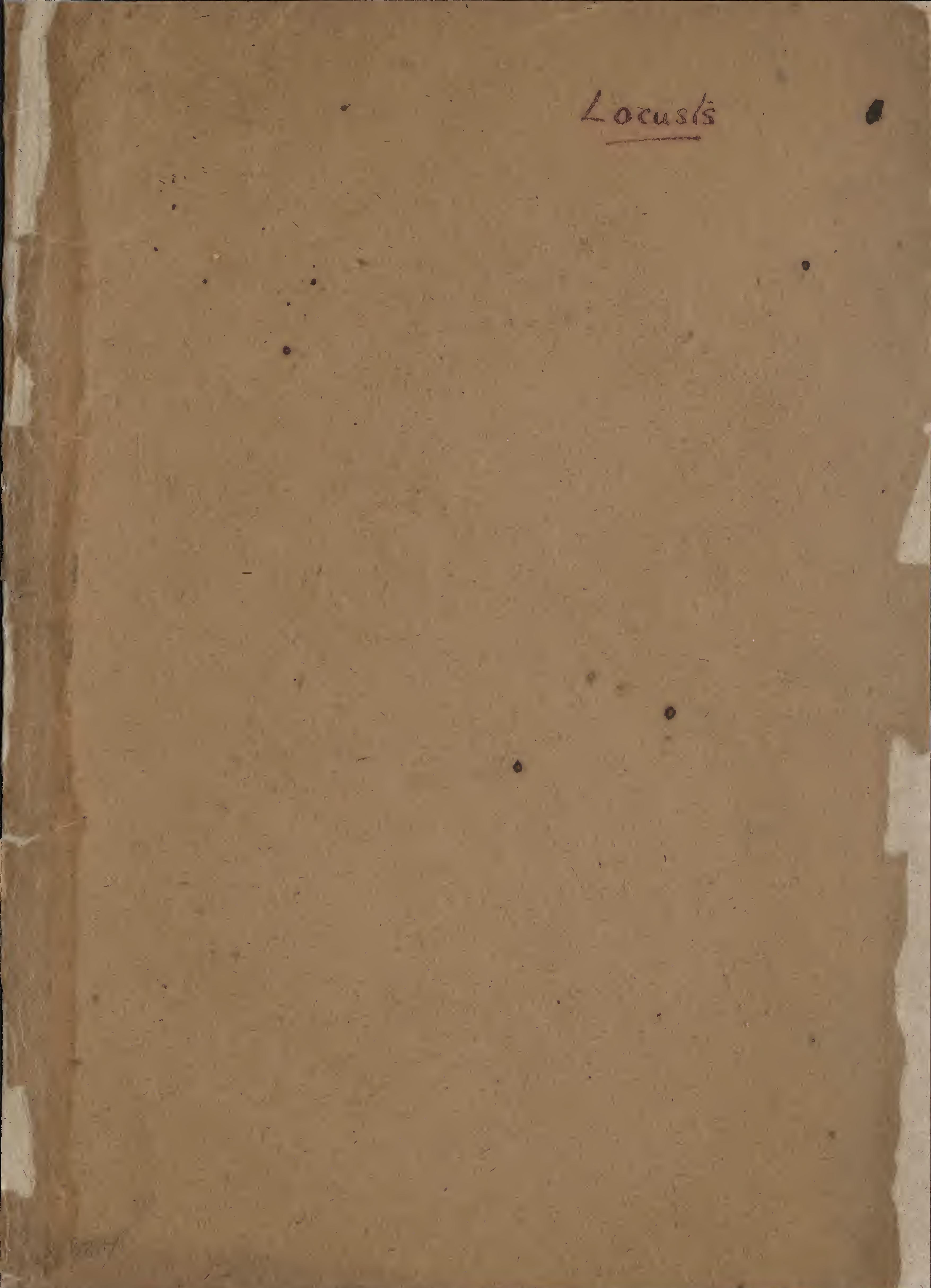





\begin{tabular}{|c|c|}
\hline From Whom & $C: I .5$. \\
\hline Place .... & 電 \\
\hline Date & $28 / 7 / 14$ \\
\hline
\end{tabular}

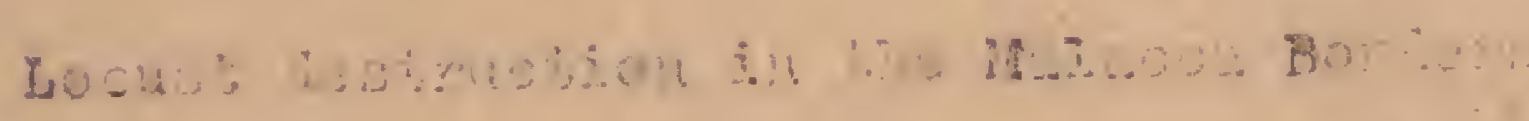

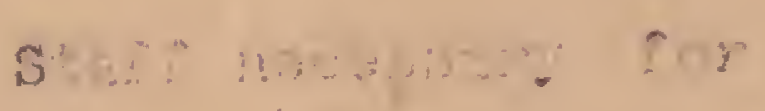

Former Papers.

MINUTES,

Final Paper.

$$
\text { C... S. } 3
$$

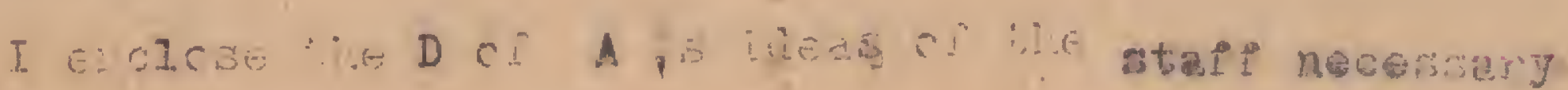

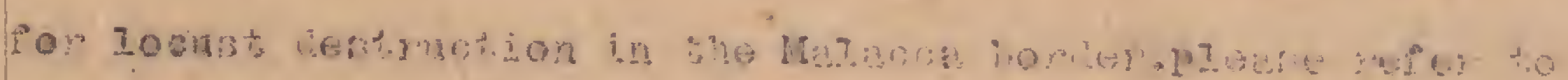
Lise $D$ of

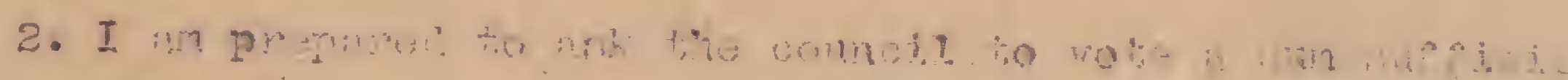

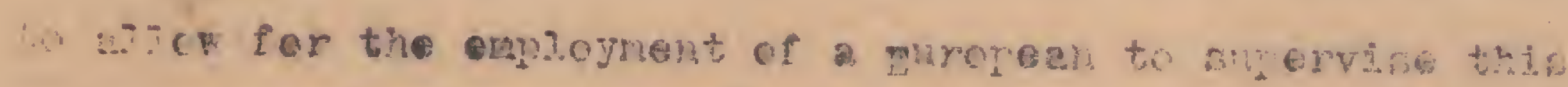
wom. The $D$ of 6 can advine as to the selection of this of ice

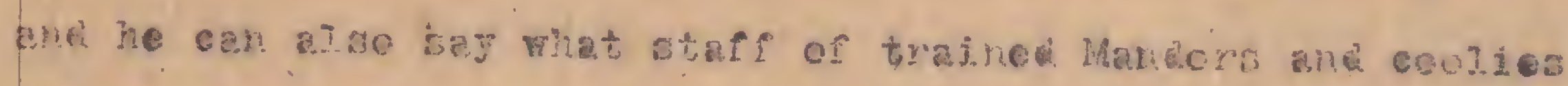
he ronil advise as to emioy.

3. I an asking the Ch. iecretary what trajuec lancors can be mared.

$$
\text { Int, R, T. W. } 25 / 7 / 34
$$

D of $\mathrm{C}$

\section{Ref erred}

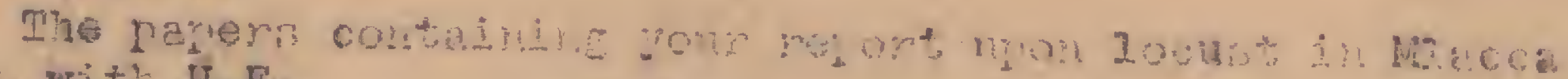
\& with II.E。

$$
\text { Int, } \pi, 6,14,29 / 2 / 34
$$


C. S.

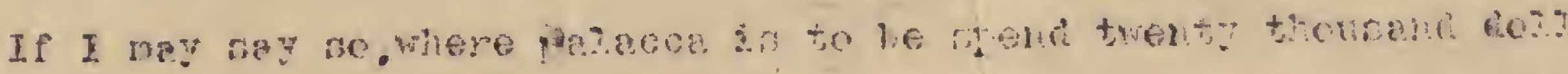

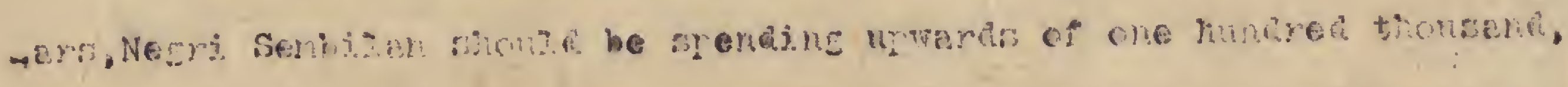

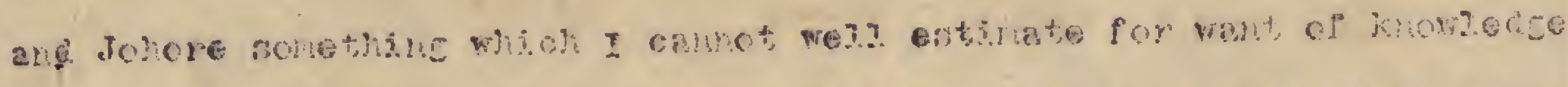

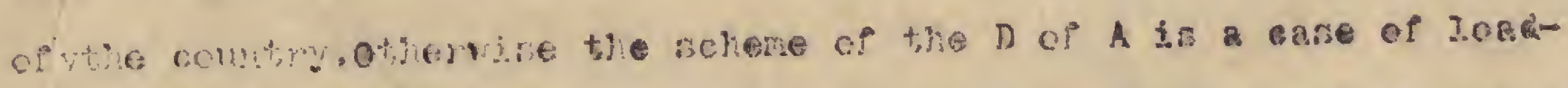
ing the work chiefly dnto Kalacea. Is Negri. Sembilan soing to mert $\$ 100,000$ on zecurt, catehine in 1915? - oxpect not.

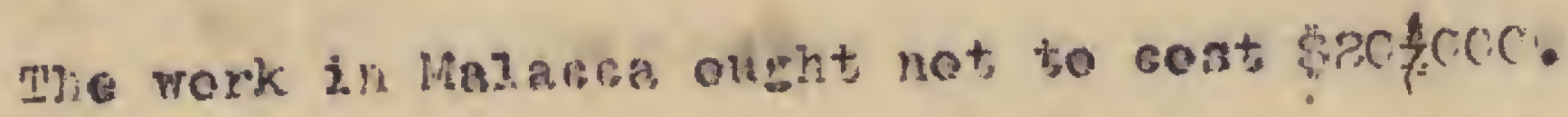

I attach a mar showing the distribution of locusts in latasen in

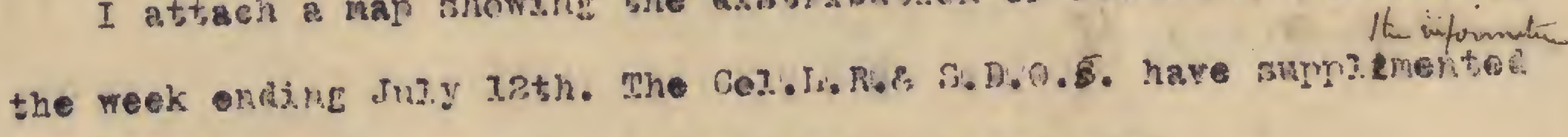
vizcs I cozectel nyserf, and it is fair?y accurate.

Pzease note that lleproris are known to ne in nine ricecafacne mun then

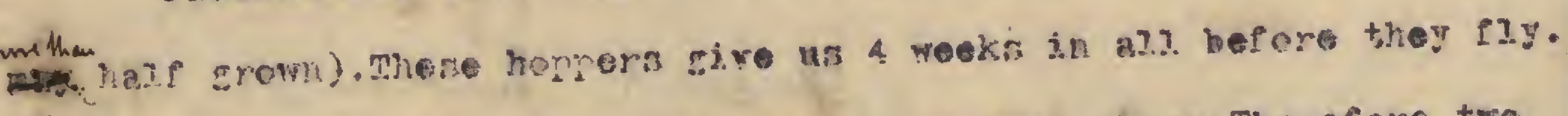
A week onght to sulfice for destrugtion at onch place. Therefcre two Mandors can he provided with work on thent Nete next that there ere 8 swams, hreaking nostsy their procerey cone

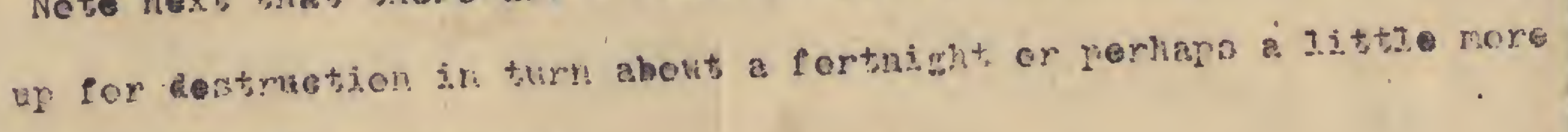
Ieter, and the tro manders 
G 33

Whas sinuge teapers No.....

.

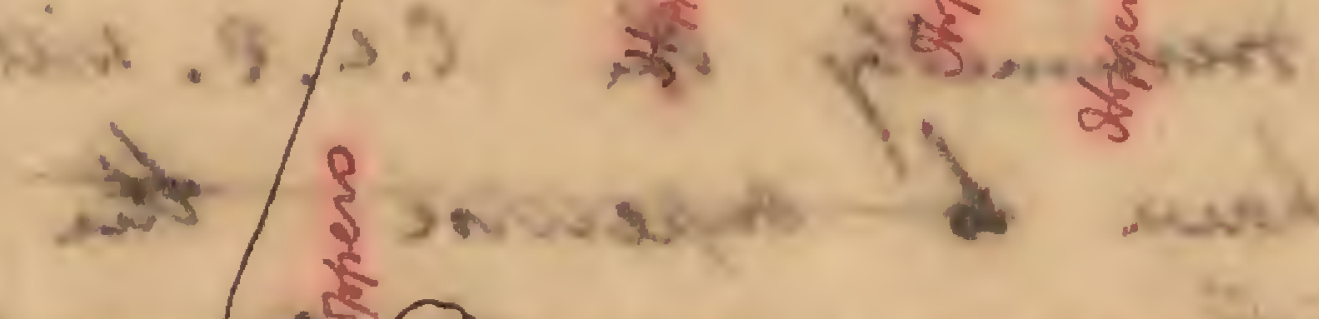

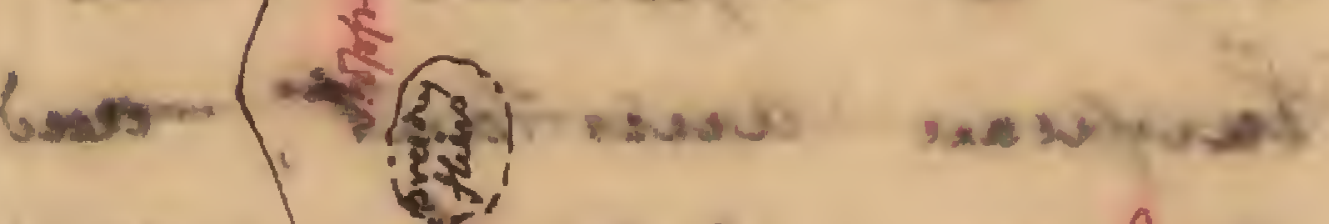

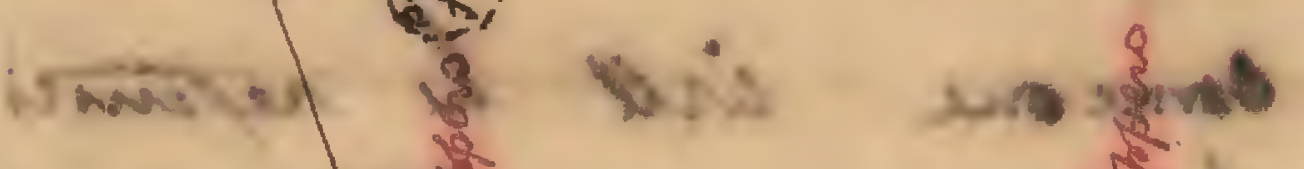

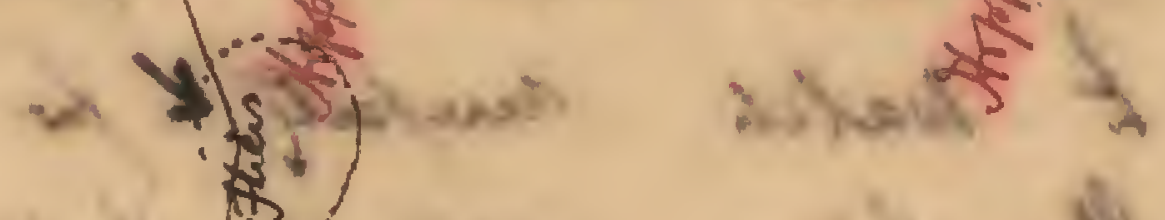

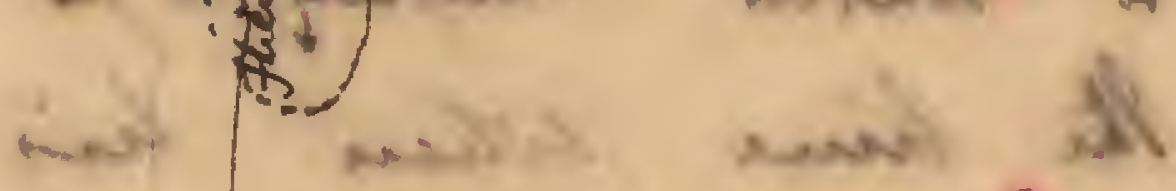
- biner $>$ a n $\xi^{3 x} ;$

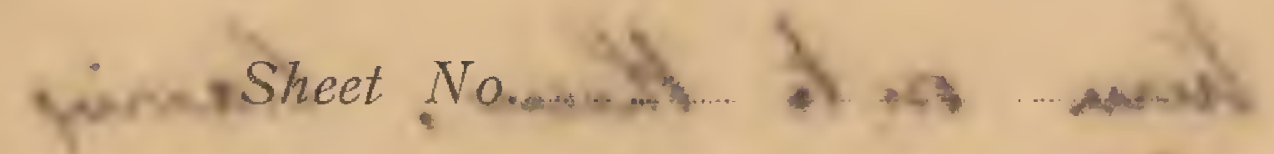

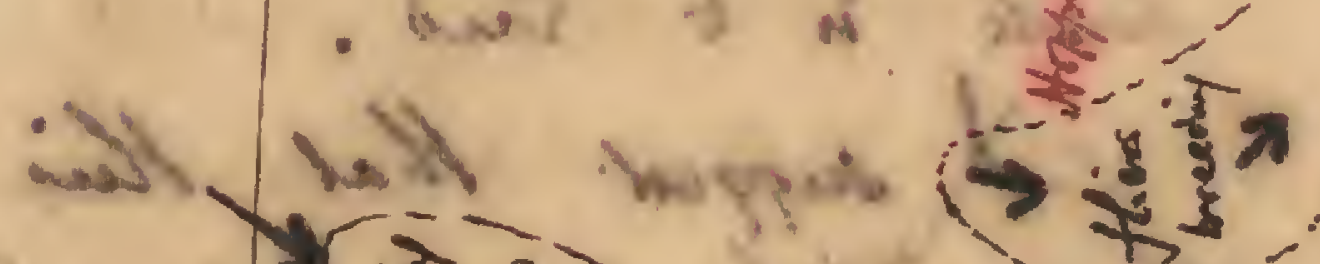

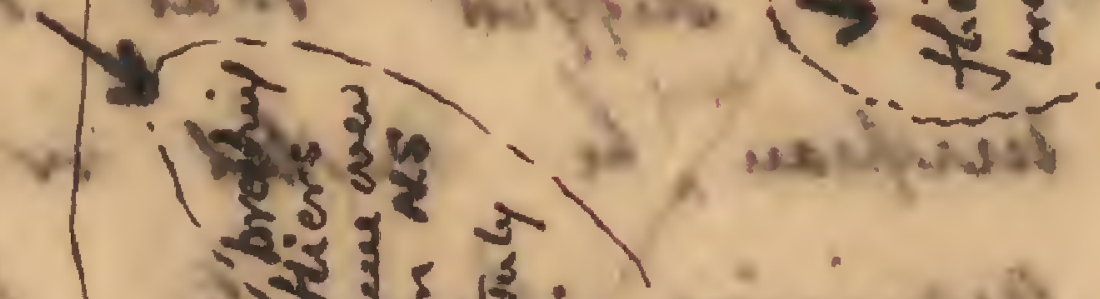

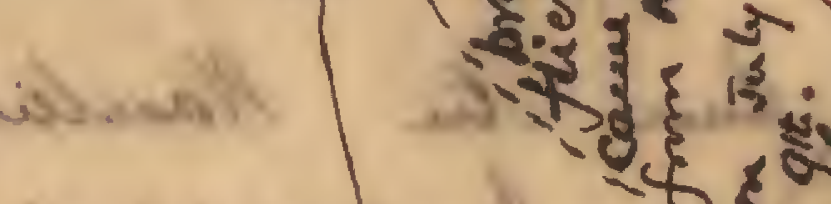

को

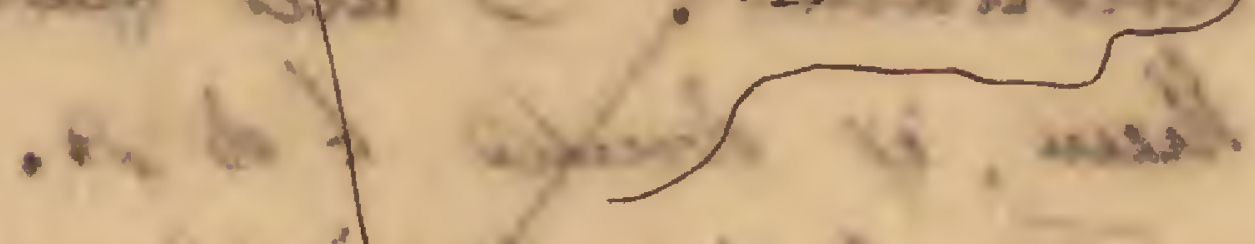

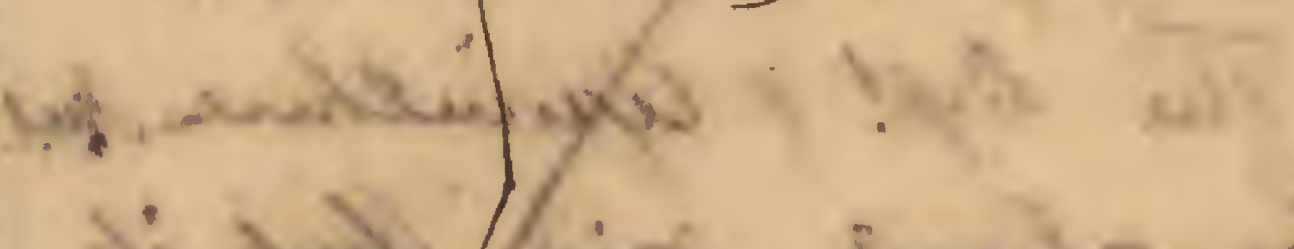

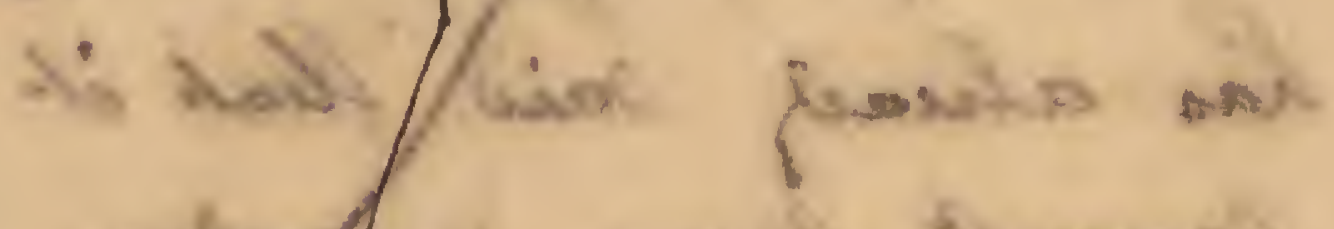

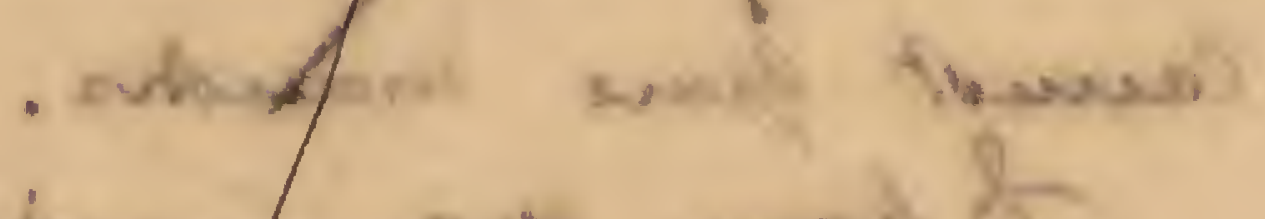

Whous

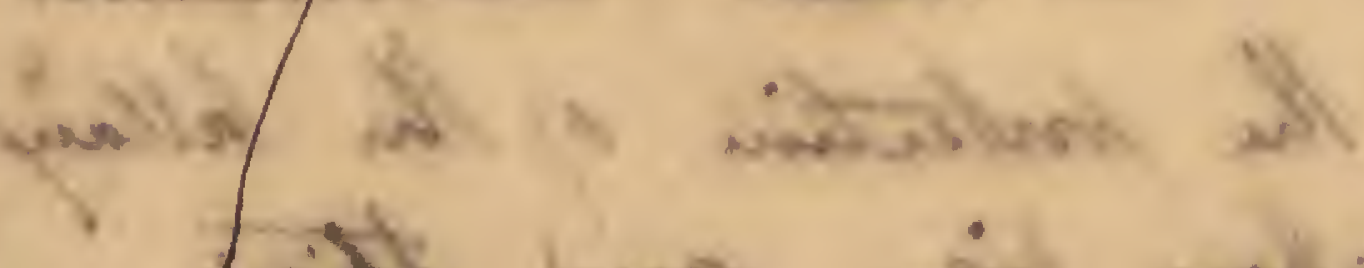

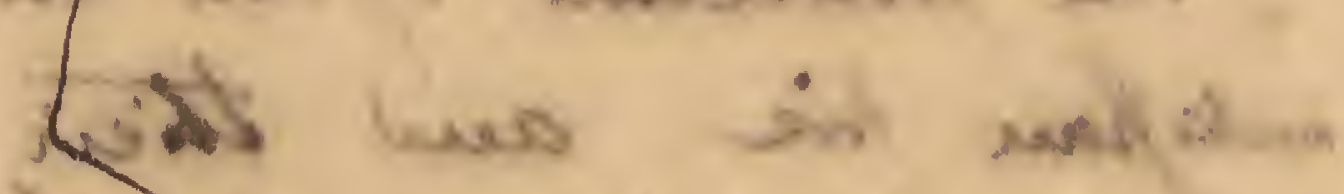

Wh

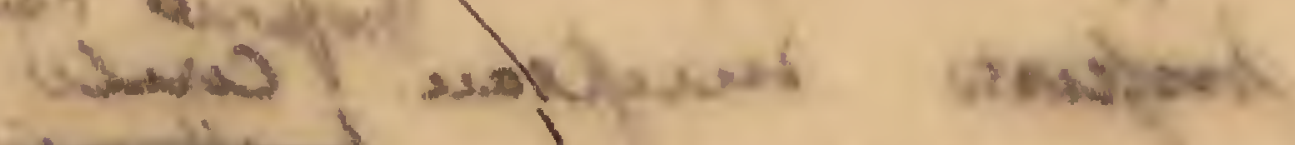

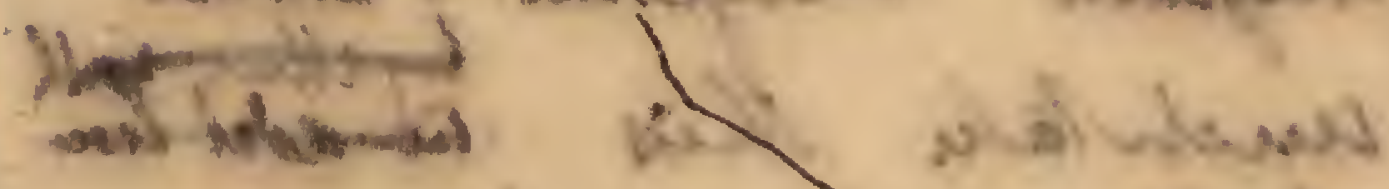
s.

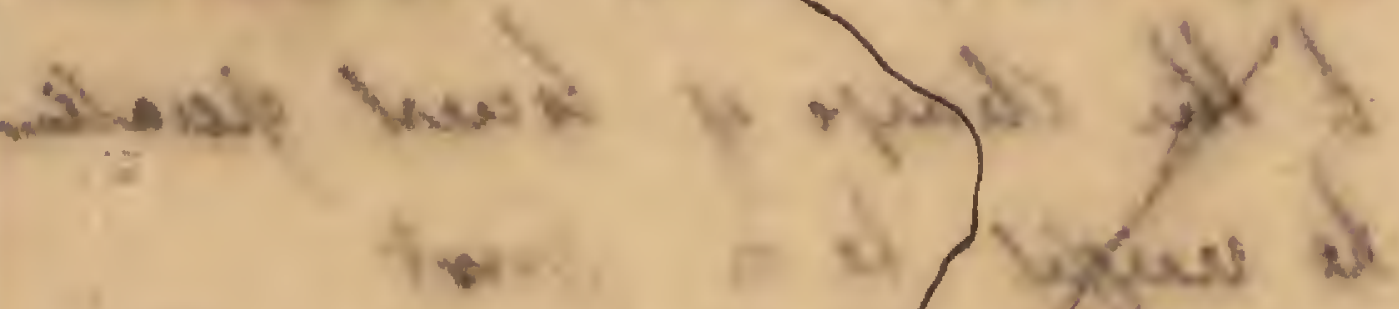

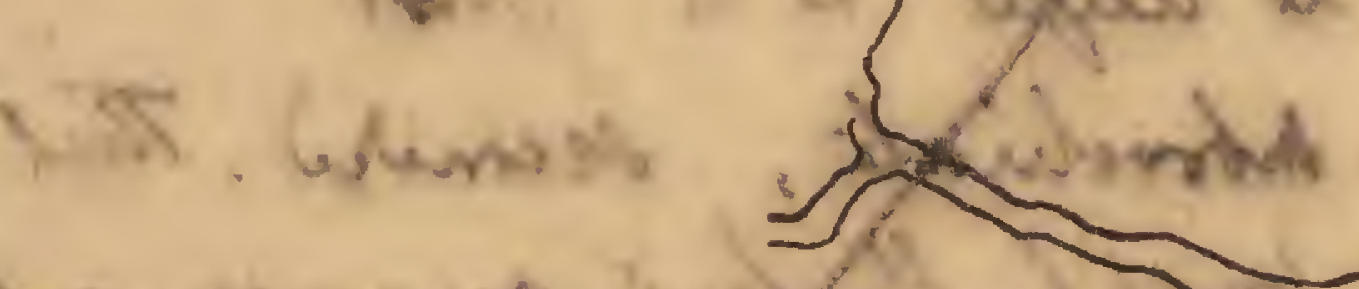

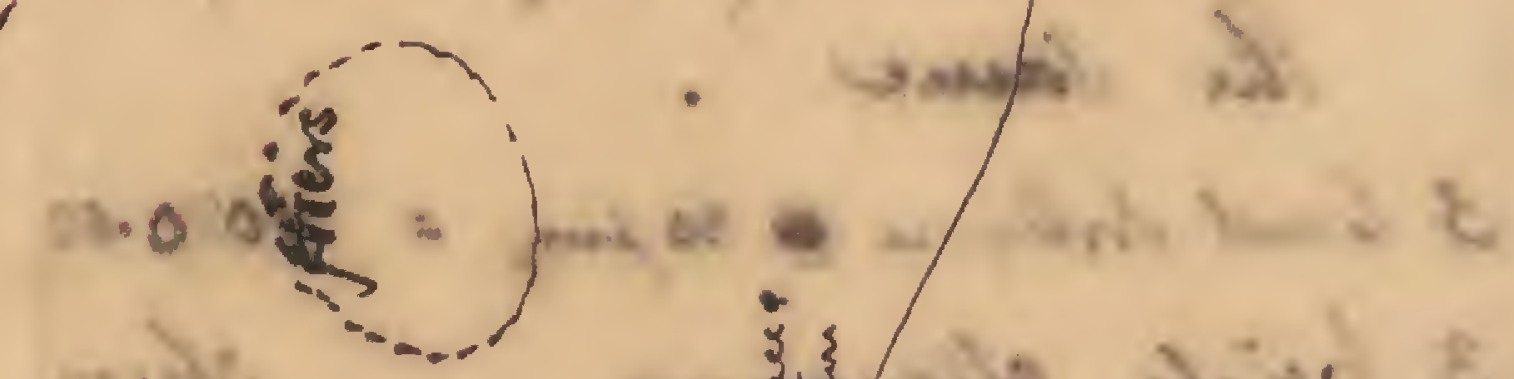
w. Whi

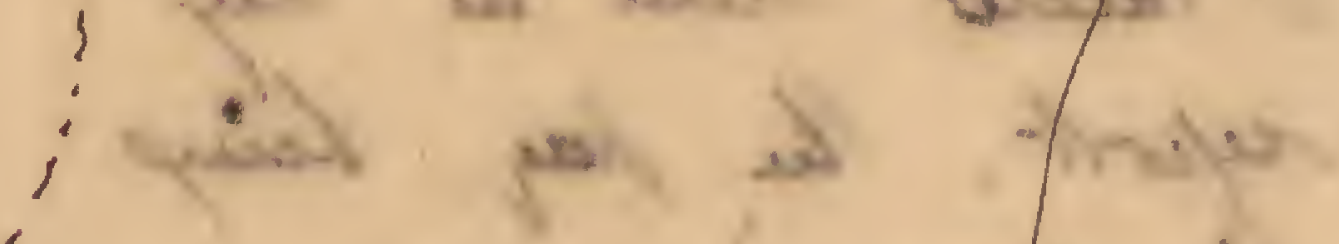


him on to thewer, having Hien, y allewow, ulearing fhw weets in which I couqlete the comin. Dllowing that thene ane Lwouns of heppees his the lallowingsts whis \& kuni untaing, I the lonk of gh tien

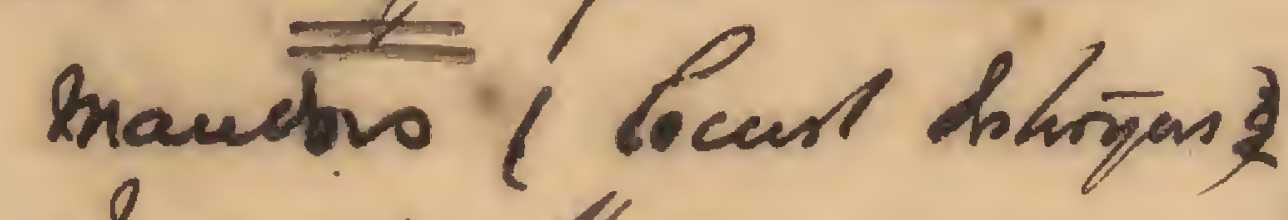
I calad themen is vey seport. the tho keing the sane).

3 boust hifognos e $30 / \mathrm{mm}=3080.00$ 3 higide allwwanas 360.00

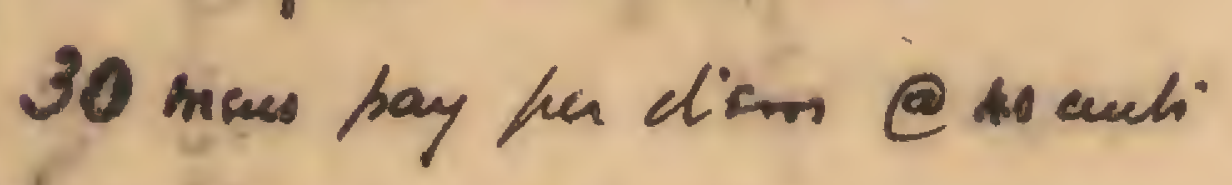

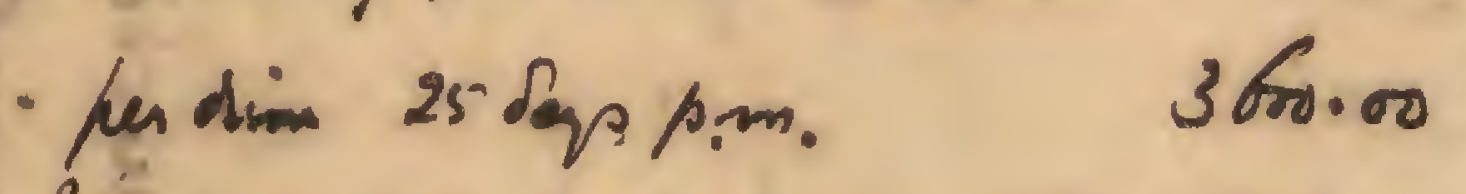
heciturials $\frac{3}{5}$ of tha dif as stmed $\frac{278.00}{5318.00}$

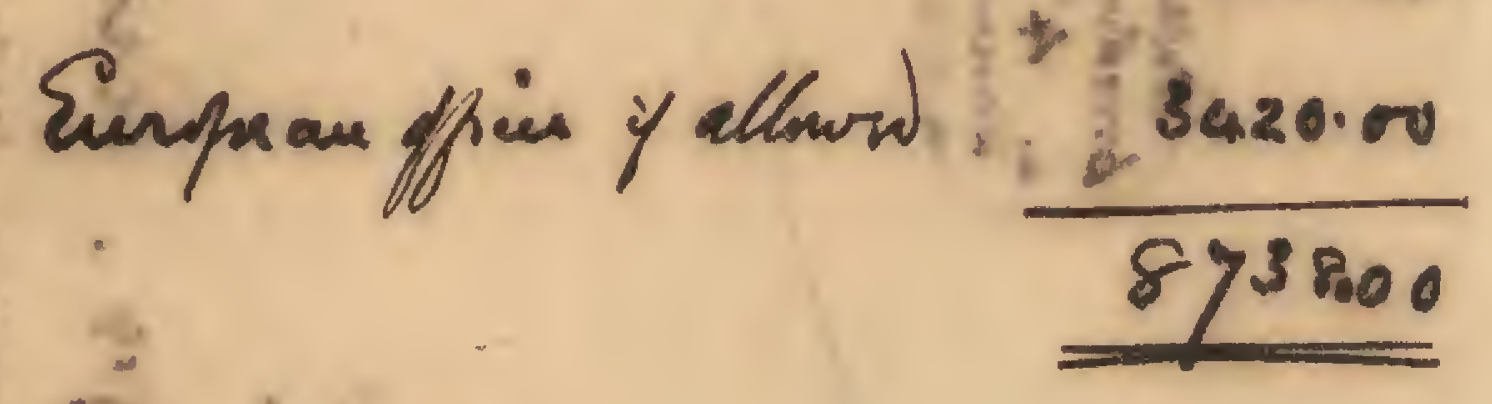

Supenisini of beust distroyas. Soncone presumesty the C.L.R. isll have of oxperise the harea anis twat, and

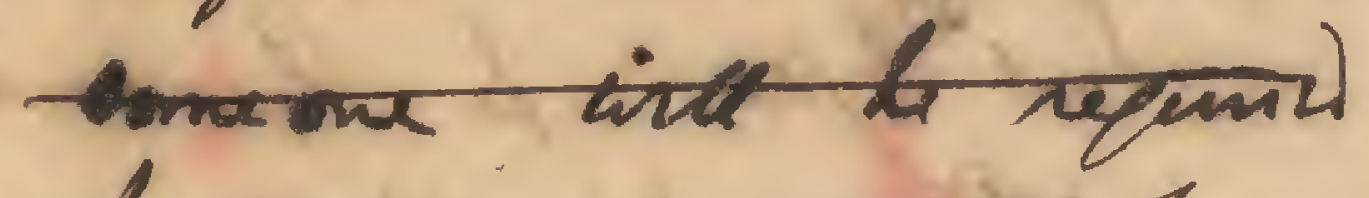

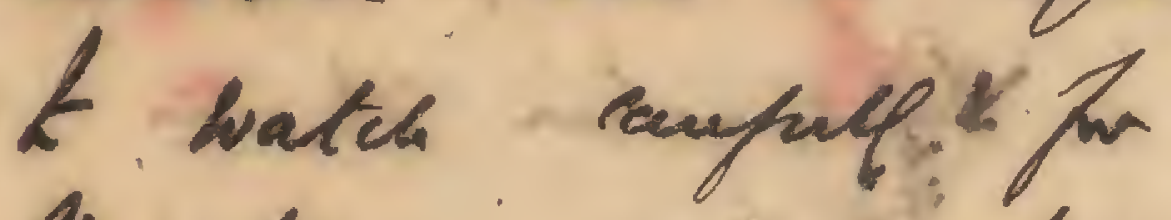
the time when his link in \& sud.

sif Cof suggent that this

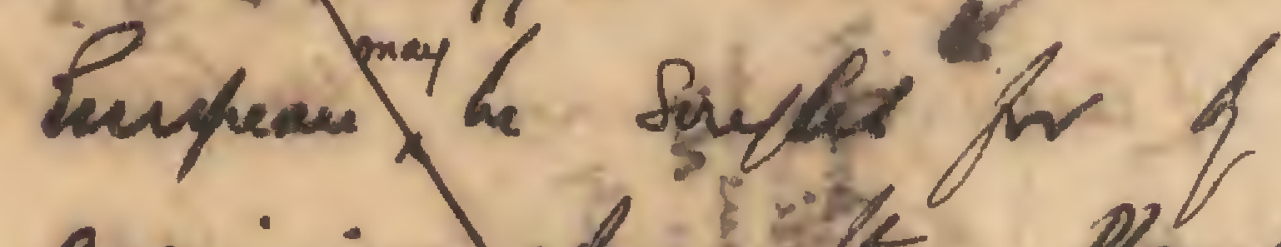
aquinices fhing the Paular Ausciation of will quech them, if drectio is dos. The Opt \& Exuciethe, tous has aheag said thas it cacunot eprane matechs. Sham nammench the pritection of the latlong

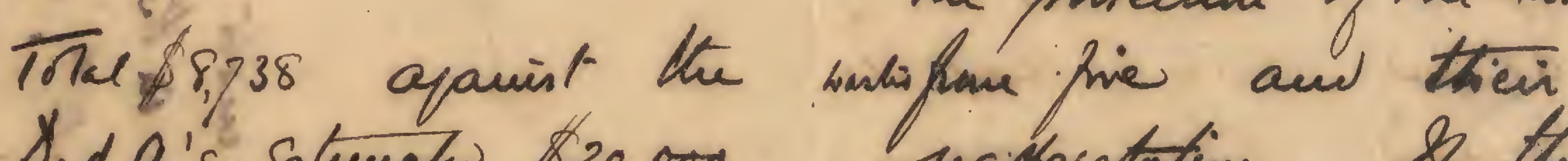

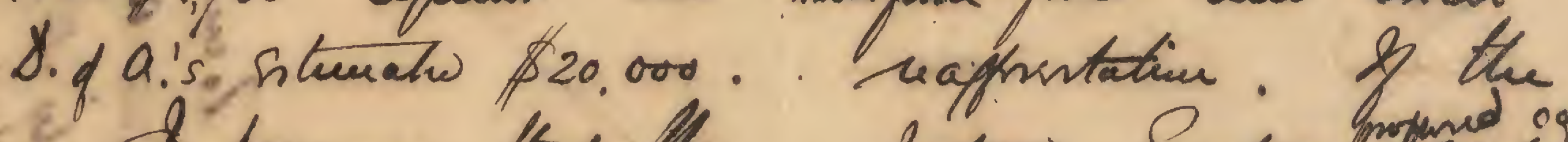
d prosume that the vituritem is to make a camerague in pis. Th bcheme wher dsame Stastur in Snelacea can Sovtur Avicts thes now or thon, the Eimpeans

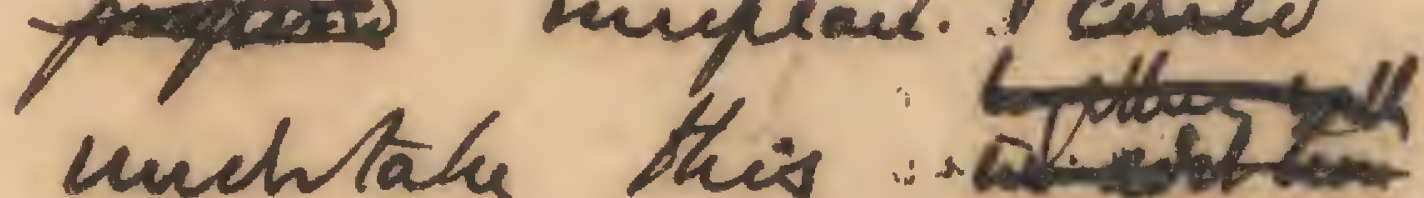

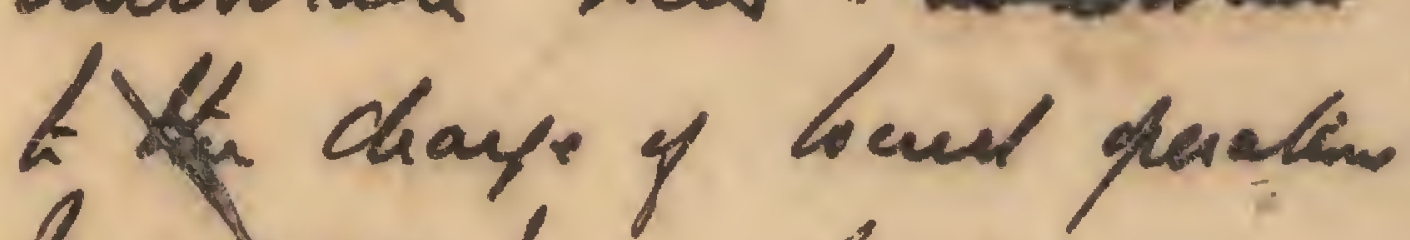
be mines Le a frost

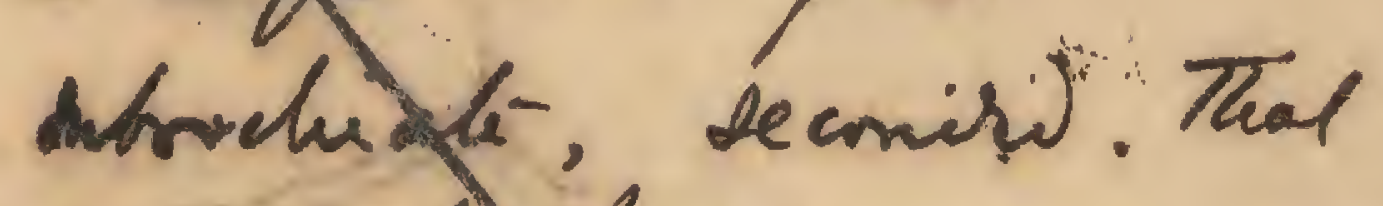
wond be th fent anarganat If all Mllubuét 30.7 .14 . ais 6 
Minute paper No.

(G 33)

lojither with bount lituretum, he will ghely Sam his fiag, and in toal care a juest pioin seconcro unues be the bat Effe of the corte puntion of finche a Yune flantontem amind on of work Lavo y coun inlenerd un knquing the bale wate for ariy haves suk for an'y hoved cond a auflo we L 3 mauids.

The appachincue of Gyi the has ahiag sav that is. cumen trave suades.

ous

20. 14
Y.F. Subnit:

The vork whing lochl the wee

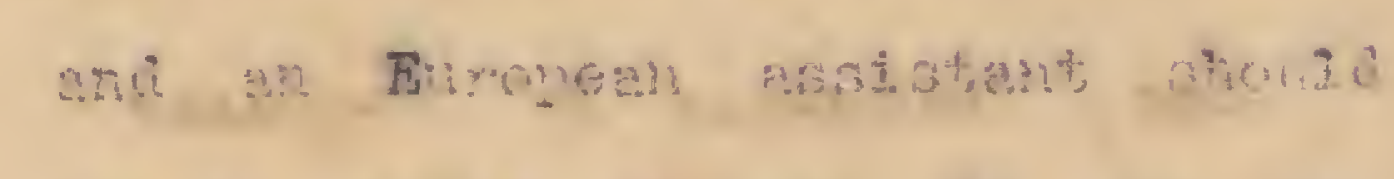
be st rocaz charca. If can bo

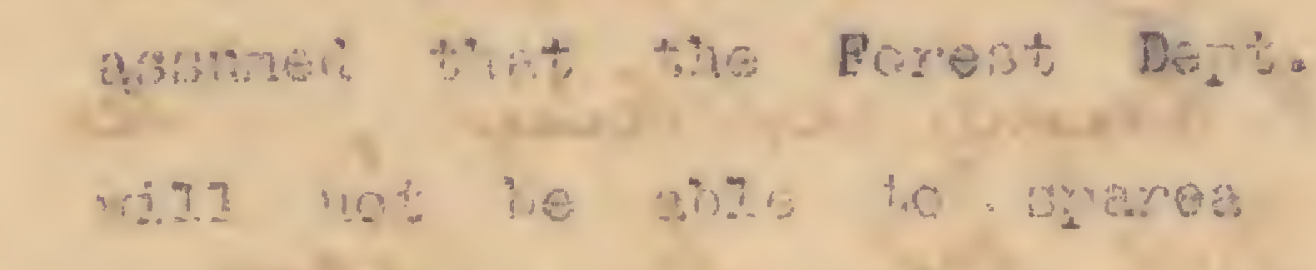
man, the ho D. of to nimenta

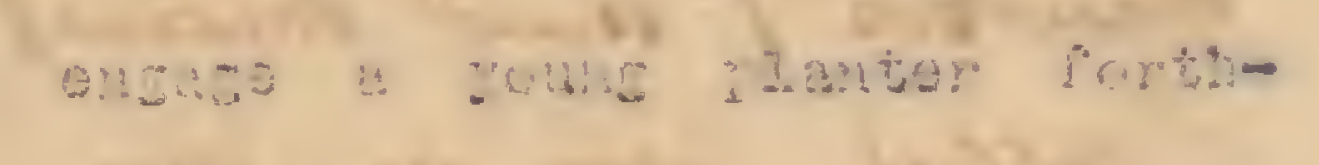

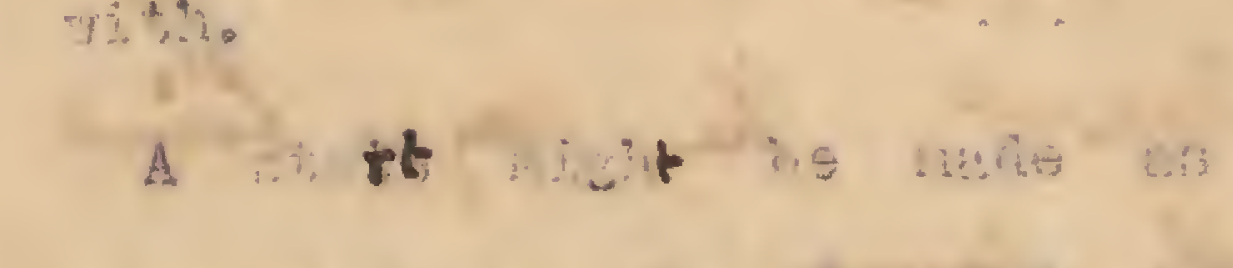

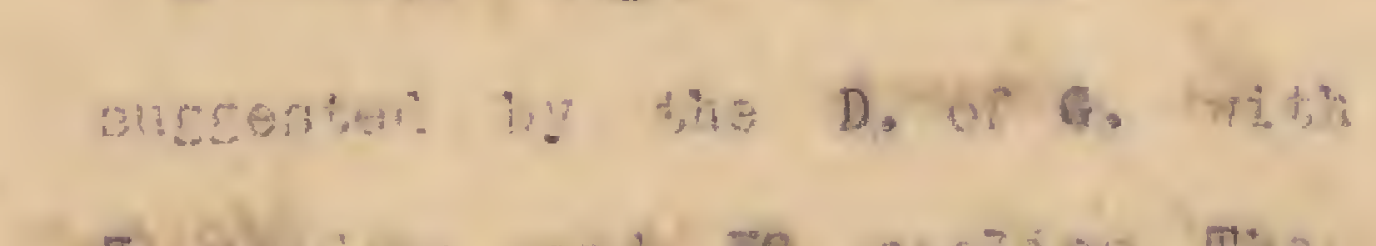

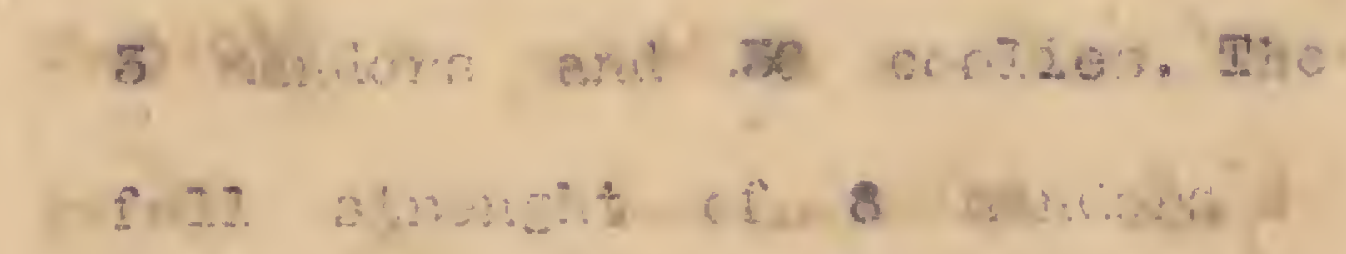

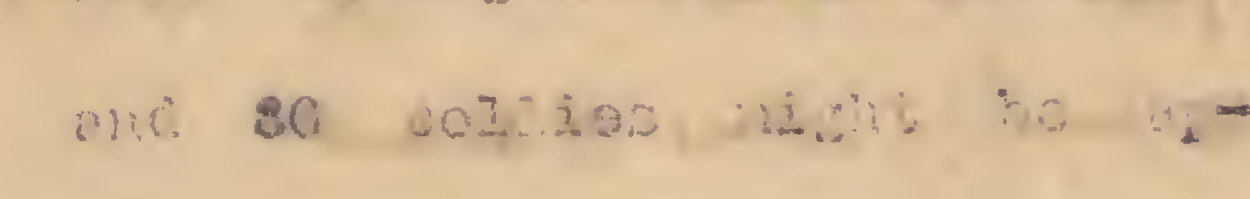

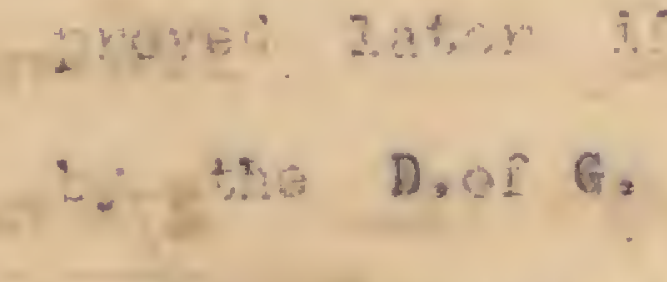

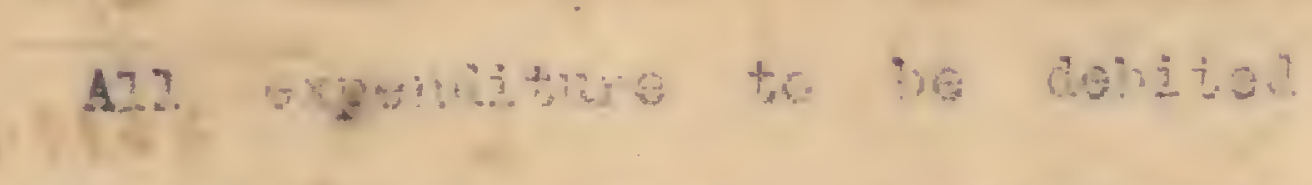

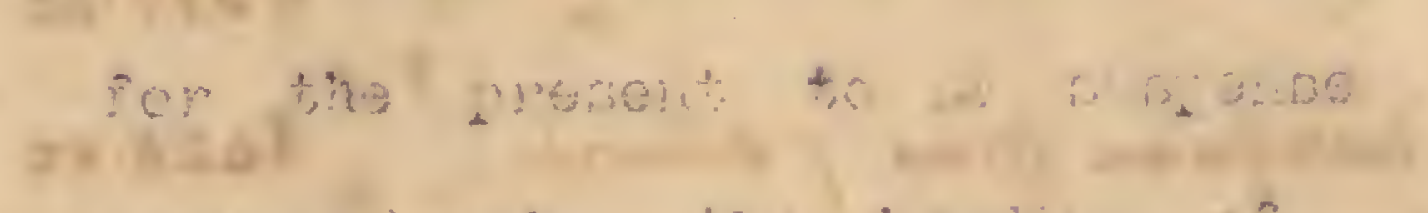
The D.of G. to regcort at tha enc

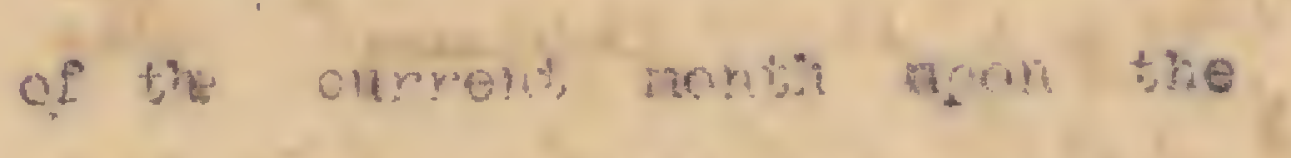
work cone and" the exprenditure incuprest, w.G.h. S.athe PS. Dees R.J. Gecilye hivy subther acticn be he taken mon the noo and atomen

(B) in ac?/24? W.Gस:

D.or G.

The ebcre har besil anproved

1. H.F. Pleare errance with 
incirentans new trang eto 400.00

to cayry on to the rul of the tean.

I nopore to visit Mazacea at the eartiort porsing

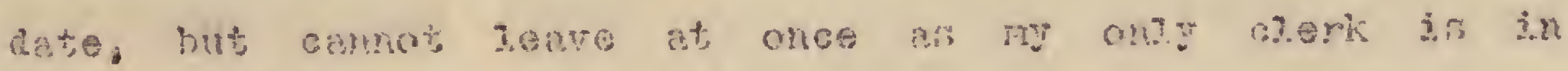

horpiting.

The D. of A put acwn faco for a rotor cucte. I find

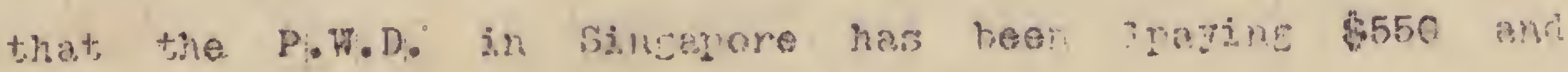

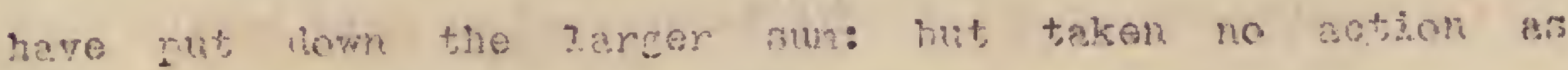

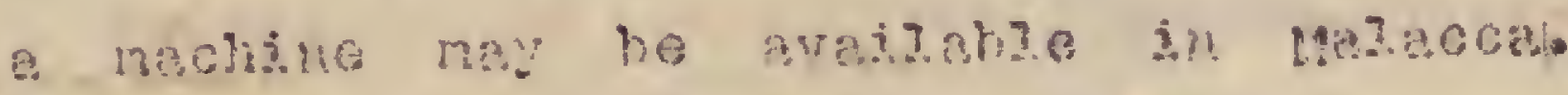

6.5

$$
\text { 2. H. B. } 74,8,14
$$

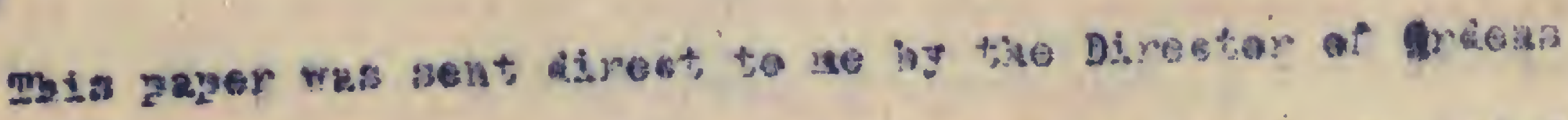

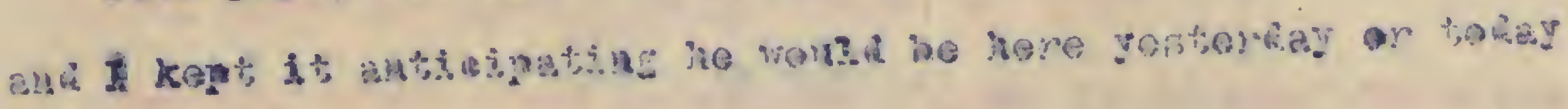
i) ht he is nat.

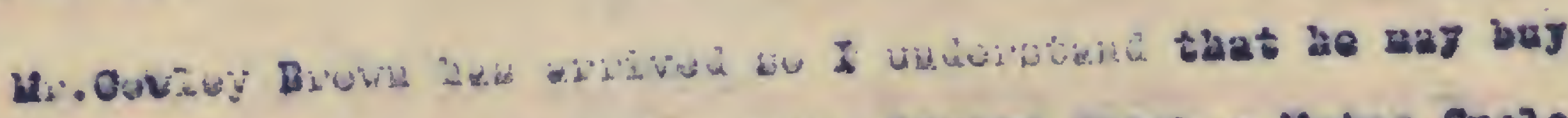

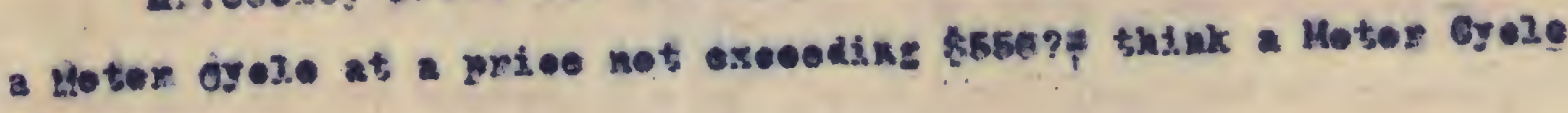
is pbrozutozy necersery.

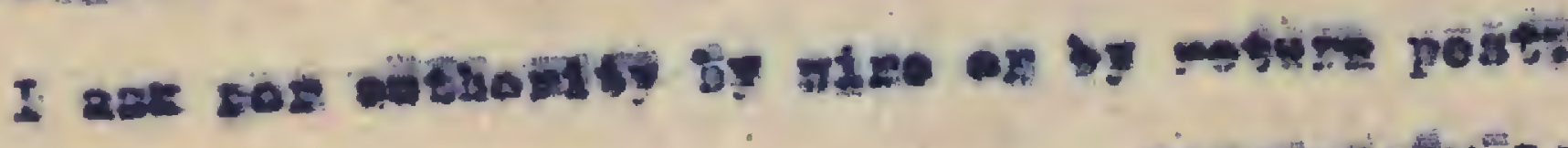

$$
\text { Intwher. }
$$

I.5.

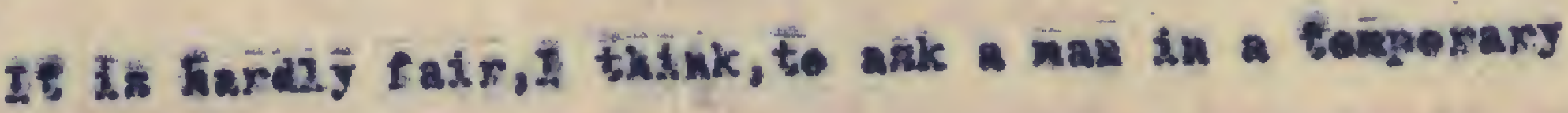
appointiment to buy noter igalobtt world be better fer the gort. te buy it, aud to pets it at his dispesal.

tat, $1,6, M, 78 / 8 / 24$

\section{co?. See}

Ios. The kater Gyele ean be provided.

8. I rote of $\$ 2,500$ nust be anked for from the pinance Comnitteo.

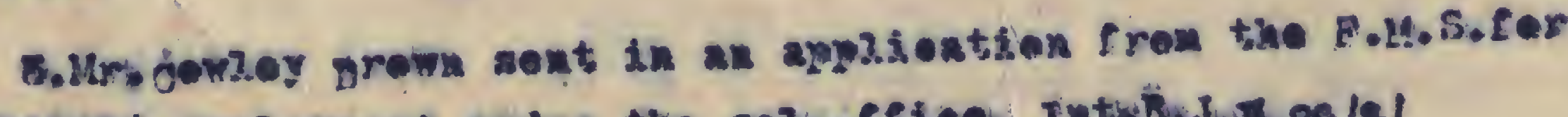

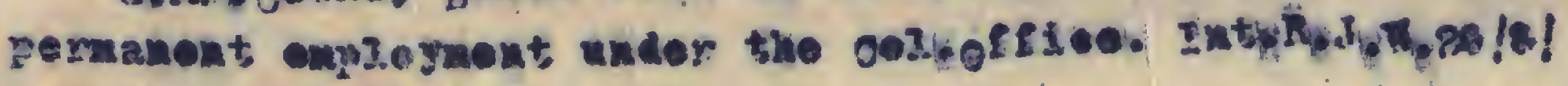


M. L.

Proase note.

Inta.T.6.4.26/8/24

6. 56

Noted

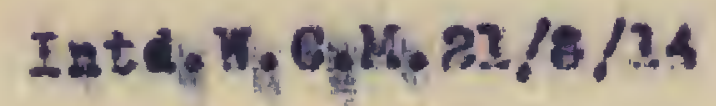

3 of 6

Pleane note

Intd, $\pi_{0} 0 . M_{0}, 2 \% / \Omega / 24$

C. S.

Your instructions dated $8 / 8 / 24$ are to the offect that I ahow roport at the end of thof I co ne. Hry Gowley prown commenced work

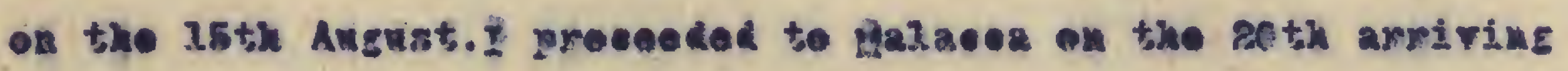
there on the mist.and in cenjunetion with the fesident and Mr. Corroy grome obtaiked a Hotor Gyeze fer \$5a5.

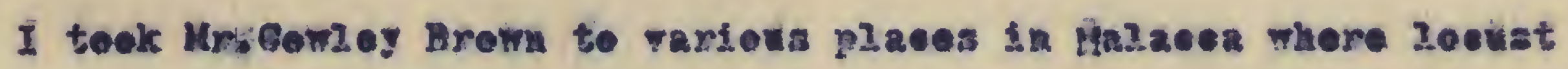
swams oxfat, toaching hin what I knew ahout zoewnts, ta excer to put hin inte the way of recoguiaing the aexes, axcortakning hon near exying the hoppors are by their aprearakee, and of knowing how near egg laying the fonales nay be by the oenditien of the orary.I alse tavent win to roognia likely breodikg srounda. Hrigowiey Rrewn had provioks?y had the zoan of many books from ac Fhich he has roed and apparentzy disestad.

It new ronains for hin to gather exporickec.l hare arked him to keep nost earefu? recerds $1 \mathrm{~h}$ his diary of the findikg of zecusts and the nature of the sirewnatance under which they nay be existix About the time of Mr.Gonzey Bromis appointmont I had asked the Moxident to be se geed ais to see about obtaiking nore trana,built

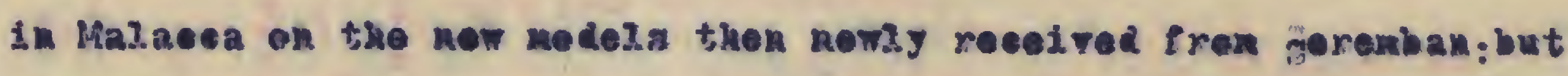
he mixio it ingosathle to set, then made in Kaxaca and was ferced again to wond to Serembah fer then. 10 tells ne that part of the traps have been reecivad and that ho has anked for the expeditious 


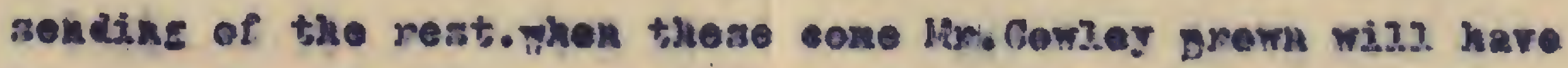
four nev model traps. Ho ongazed a second locunt destroyor last zook,but the aak ia net yery well thenght of wy either of us . he sils. he given a tair trial, and nhowldthe fain to give natiatactia

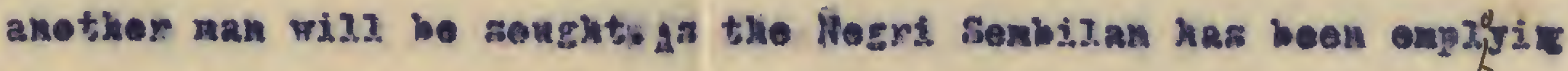
24 Mandors: and in diminging 17 , a now man ney he fond eandy.

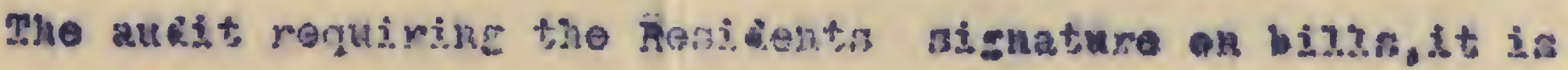
quite annocorisary that I wheu? see then. mhe oxpenses to late are

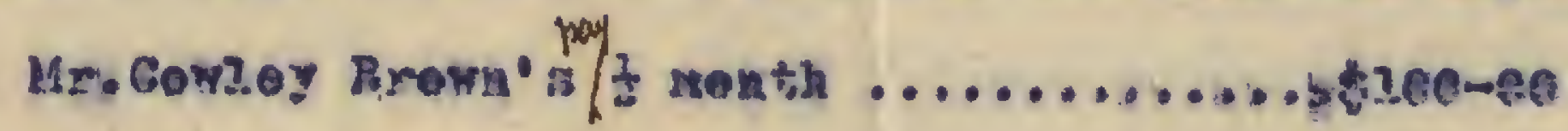

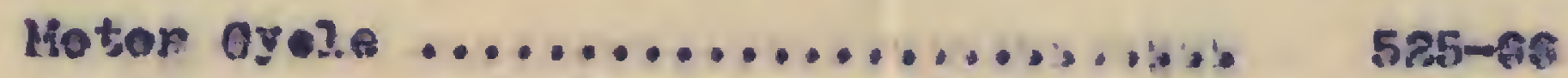

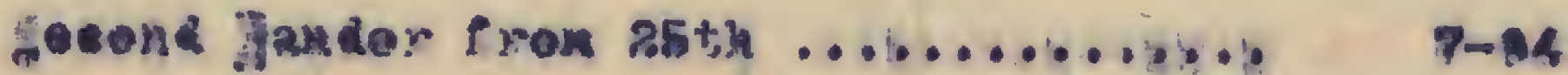
mraps abent $\ldots \ldots \ldots \ldots \ldots \ldots \ldots \ldots \ldots \ldots, \quad 360-60$

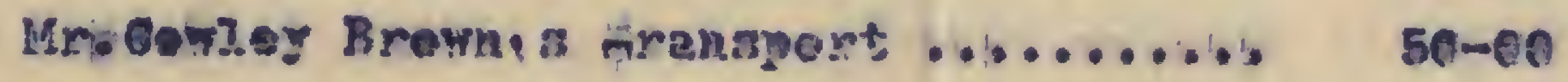
Deolion abott. ..................., 80-en Tranapert of trana say $\ldots \ldots \ldots \ldots \ldots \ldots$ 10-ee

\section{$4878-34$}

which chargen are aditiona? to theat inenvred against the ole arant of s5e0 whick is mas nag up.

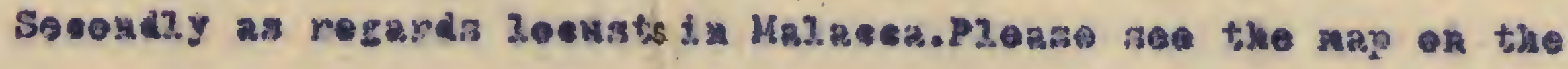
baek of sheet, 2. mhe lecksts which vore hemperm at, the tine when the wap was nade, are fliers new, and are he longer where they were: mhe fliern of the time when the nas was nade hare left

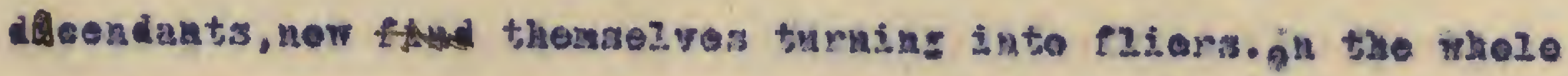
the infowtien of Kalaeca in zems than what it was, and the broed-

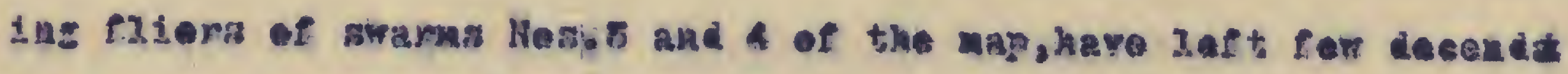

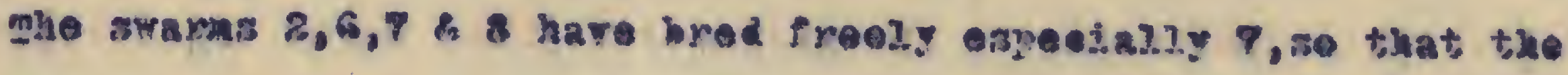

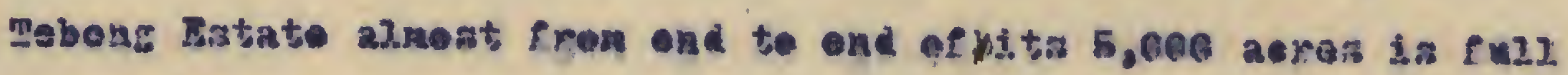
of locints 
P. .ง.

The third Icenst destrozor in net earsed for get, but when

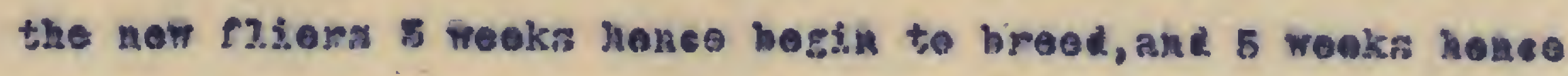
their hoppers begin to energe, jt will be seen if he in wanted.

\section{Inte. J, H, R, 52-8-14}

\section{Y. E.}

Subribied tor infrmation, whe delay in chtaining tray

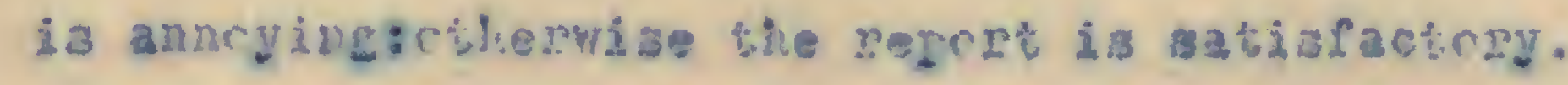

\section{ILD.R.W.G.K.2/9/24}

c.s.

\section{1 astee}

Int:G,R,J.T. 2/5/14

R. H.

To are

$$
\text { Inte.s.the } 2 / 8 / 14
$$

o.s.

seen

Iมใล. M. C.M.4/\$/14 


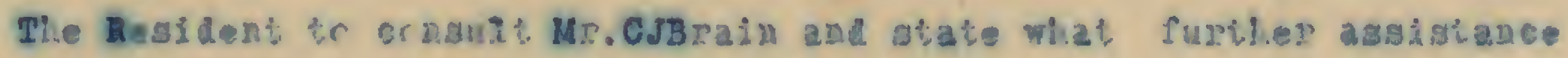
is reguired.

\section{I:Q, $\pi, \mathrm{F}, \mathrm{W}, \mathrm{B} / \mathrm{e} / \mathrm{1S}$}

R.M.

Ecr necesareg" action

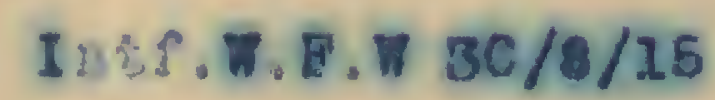

C.S.

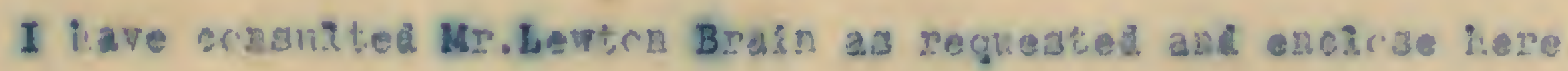

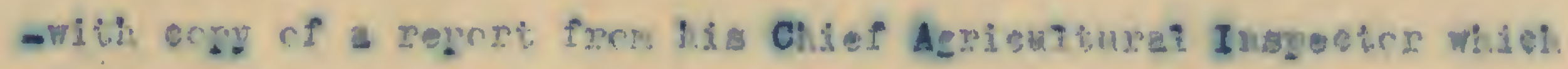
he formanded bo ne.

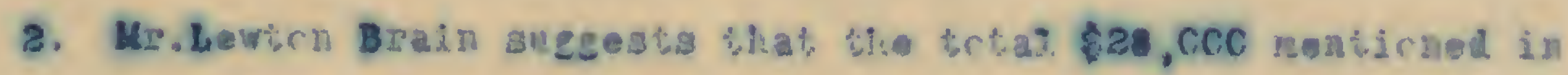

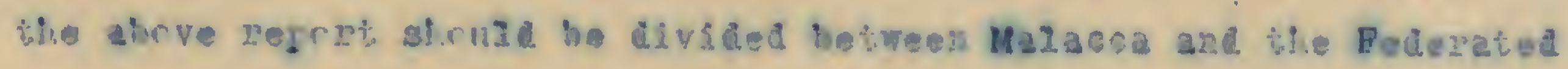
Melay Statos.

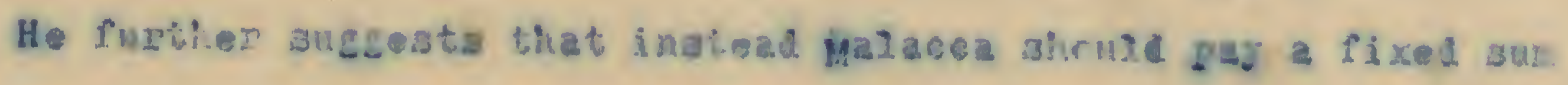
of say 2C, cco to the Poderated Mey States Irchst weconst and that

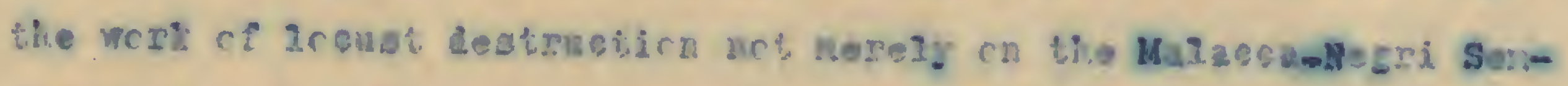

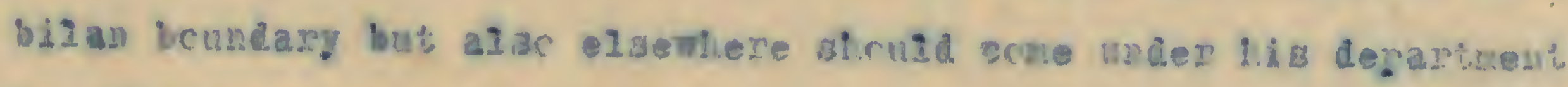

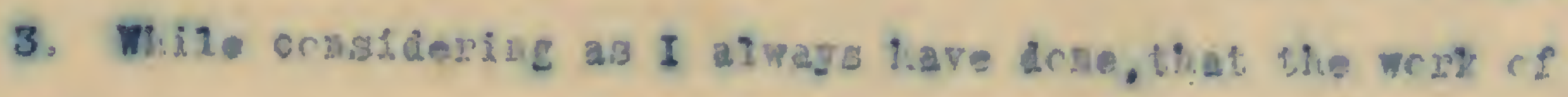

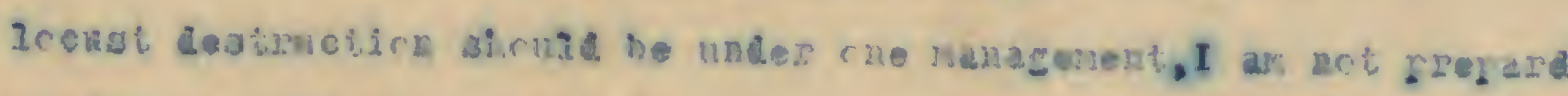

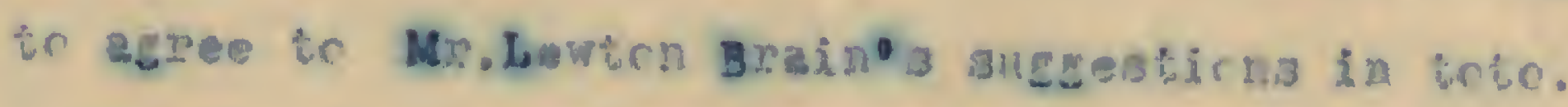

In the first place I sae that he joirse srrats is included

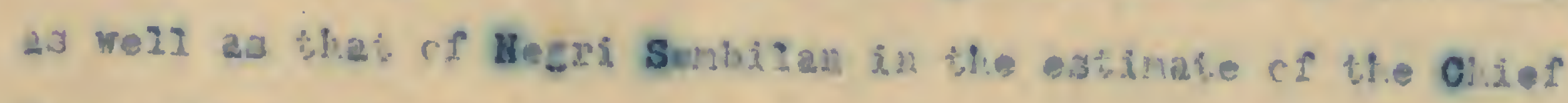

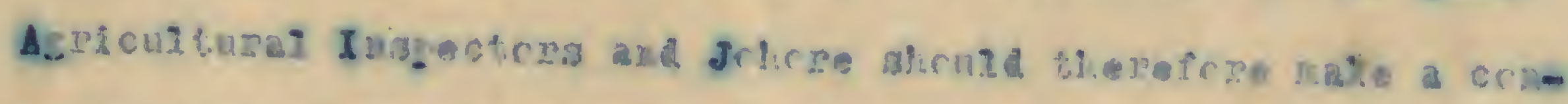
tributirntrwanda bhe vayenses

In the mext rage I thiut the ostinate far tor highofor if the

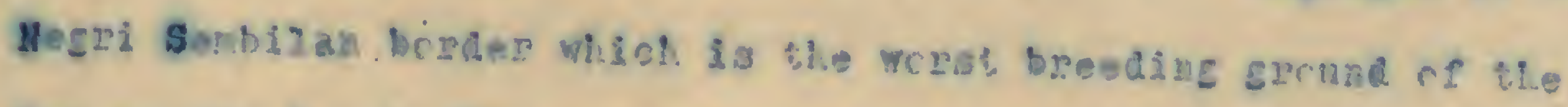

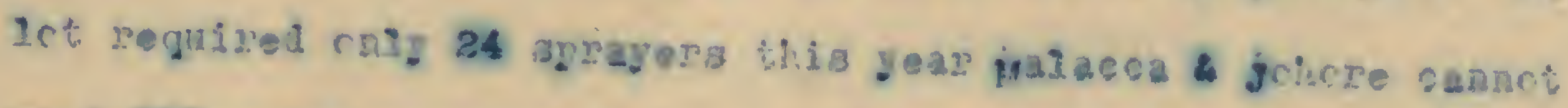
leod ICC extra aprajera bebved iner.

I siruld ang that hice exthate cruid be almosit halved ay $\$ 15$, cco and I thint thet Marace ahcura contribute \$5,ccc T. shail rrobably arond just cver t10,coc his gear on locugi 
desiructirn in Masace.

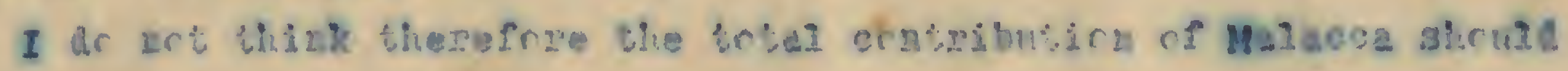

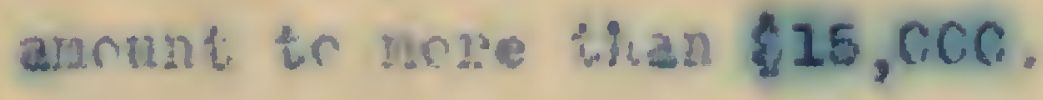

\section{Ined, $, \mathrm{C}, \mathrm{N}, 6 / 20 / 2 \mathrm{~s}$}

R.M.

There has beer a rishate. Mr.Crwtey Brwh is yiews weps ranted and ars tirse of Mr.Levtru Brain.I an Brmy.

$$
\text { ID. 2. R, J, W.8/1C/15 }
$$

C. 5.

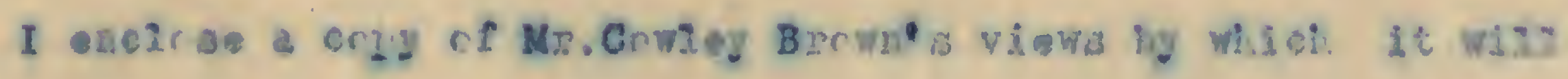

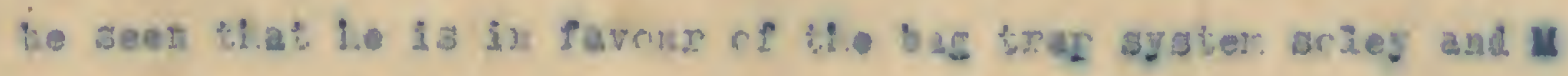
againat, ar raying.

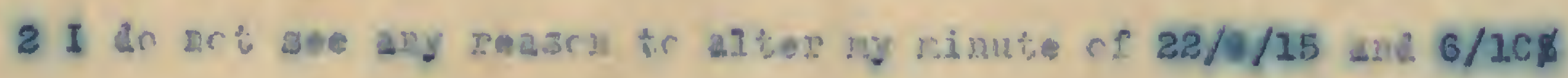

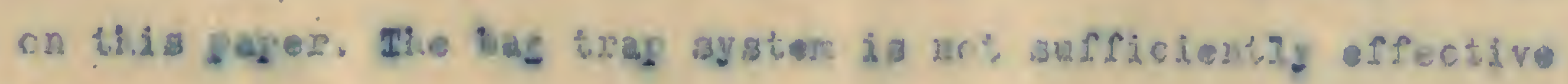

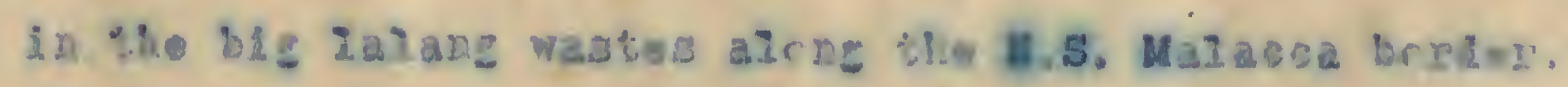

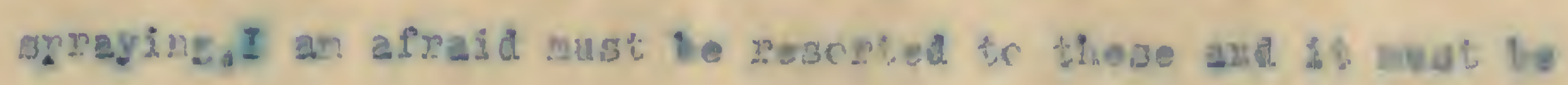

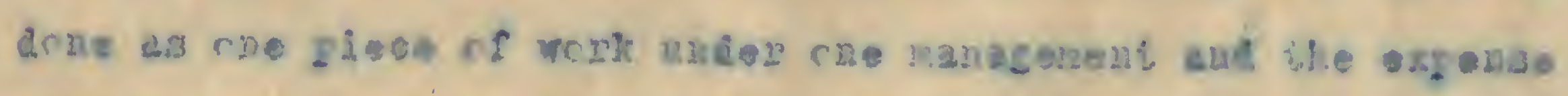

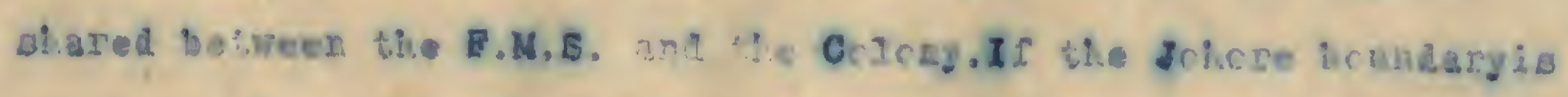

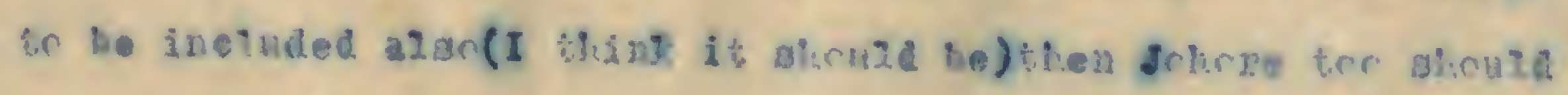
atane azon in the erat. 
sir.

With reference ir grun rarer $\mathbb{N}$. 2544/15 I have he

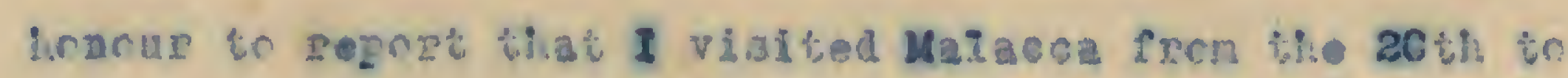
th. 24in ard diseusised Ircust ratiora with the Resident and Mr. dowloy Brewn.

2.

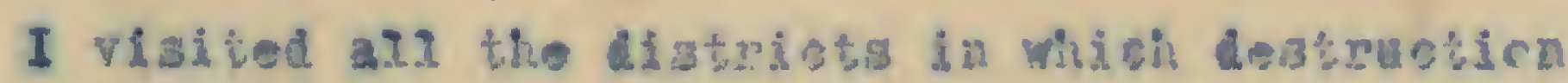

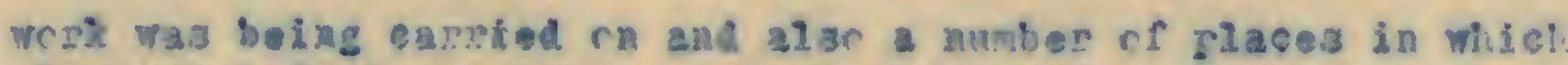
lccusts lide at one time or anntler ceerred.

3. The woxt nay be divided into two etasas-bhat aroug the Karprngs, saral:a, and estates rasticulaniy in the coutral Diat

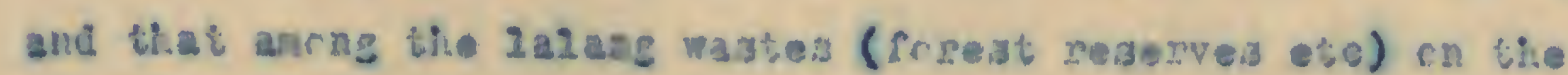

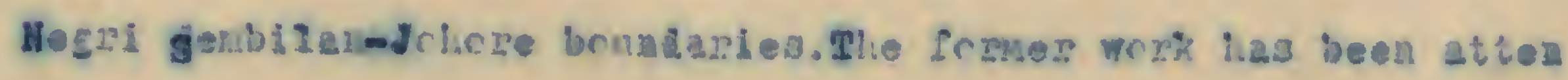

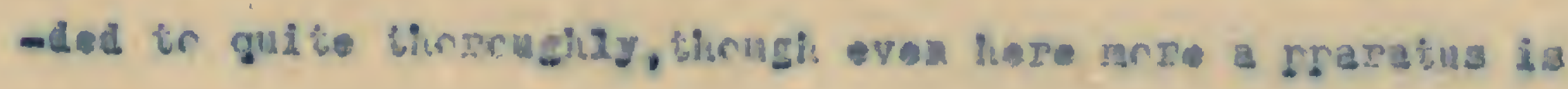
required.

4.

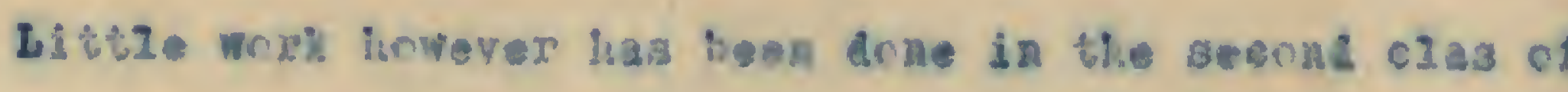

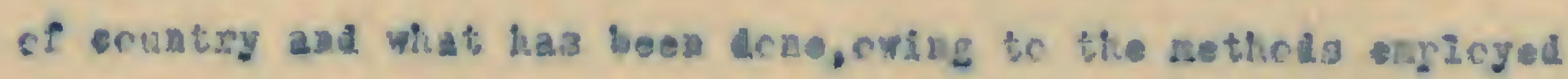

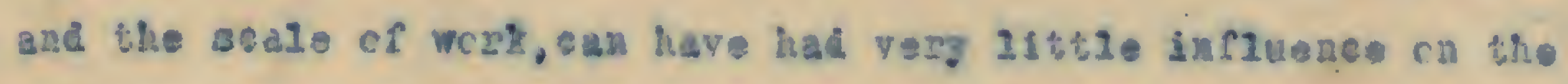
incilente of the Icensts .

5. If the deatrucsion work in Karacea ia to be campled cut on the save Iined as in the poderated Maray staten and Jnicre, it will be mecossary bo deal wis! the lanang areas such mrie

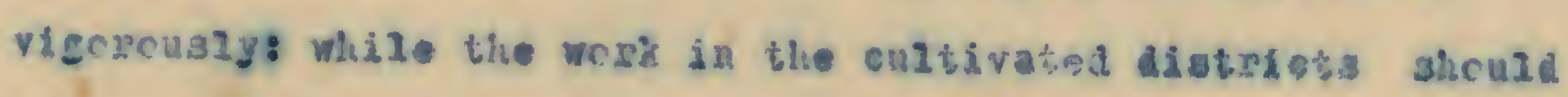
be carried ra as befere.

6.

As regarka methra, I think bhere can le ke drubs

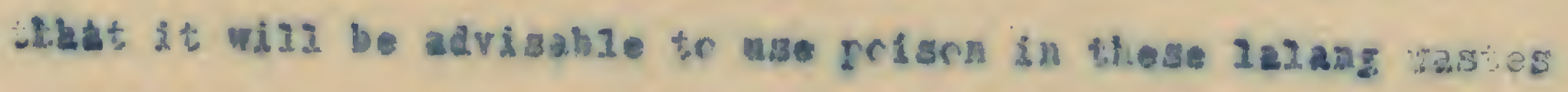

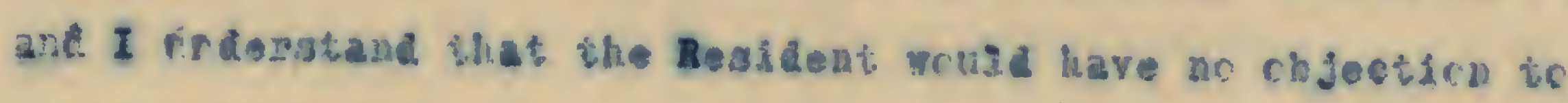

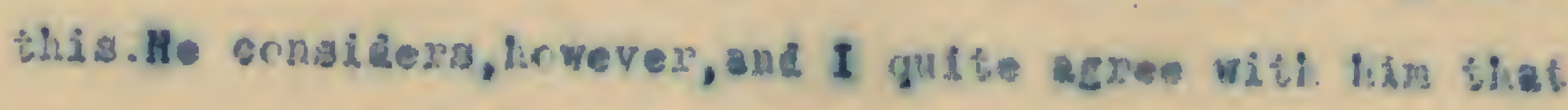

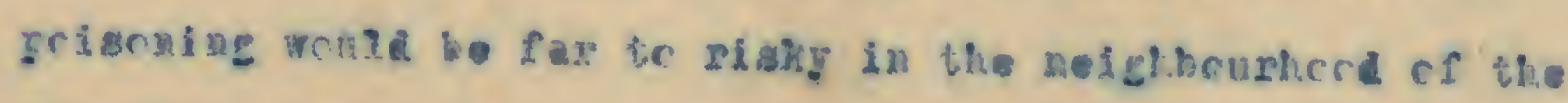
Kamprugs and here I am afraid it will be necosisery to retain the sinven bat-tray netlire. 


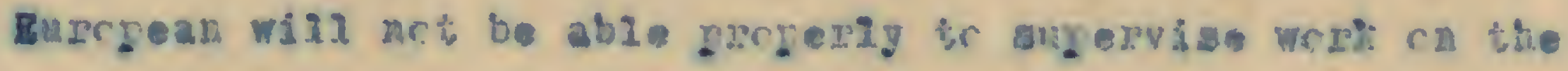
ines suggostod end I za areid that 15 will be necesary

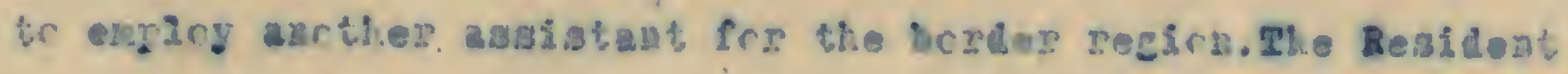
succestod that this assitant shena be atatirned at Tarpin

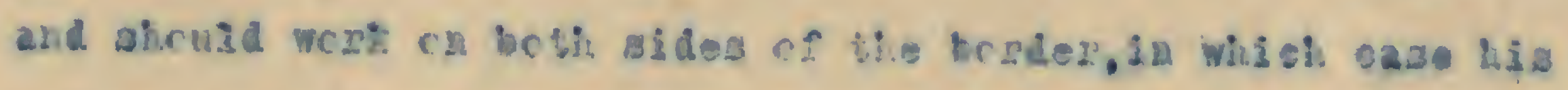
salary and allowance wrill be shared botween bi. Bederabed.

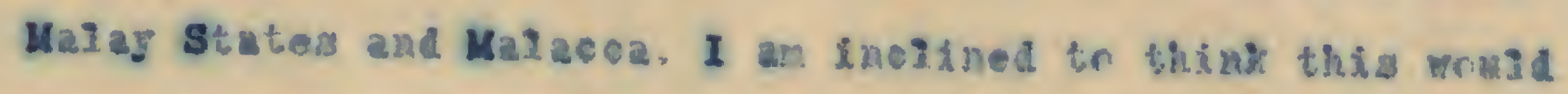

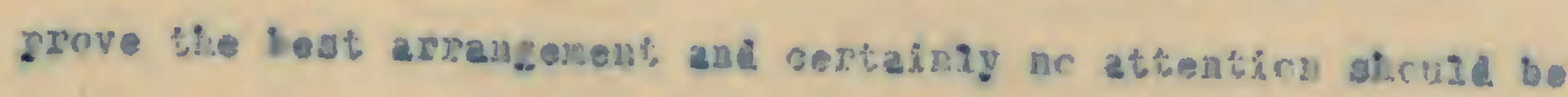

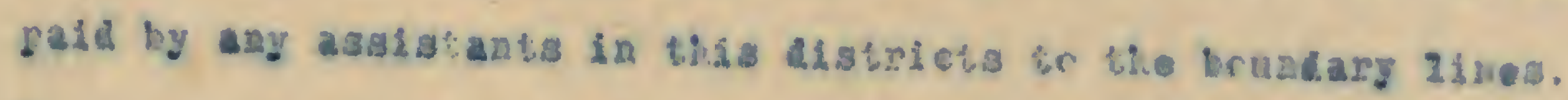
8.

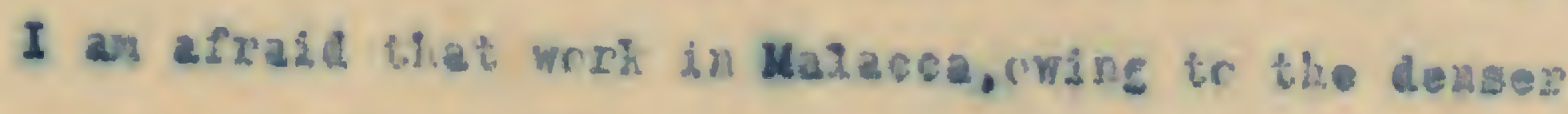

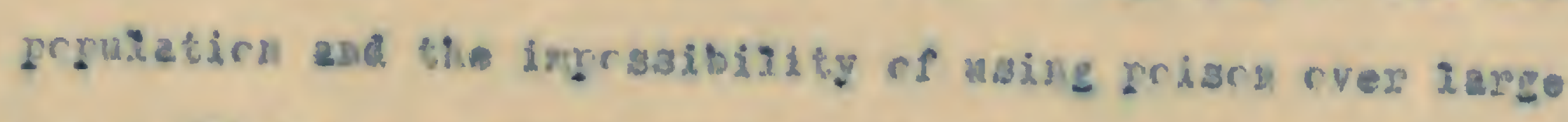
areas wil be wrre expensive than in the Federated uatag Stated Or. he the rresent I underatall that exronditine las avenaged

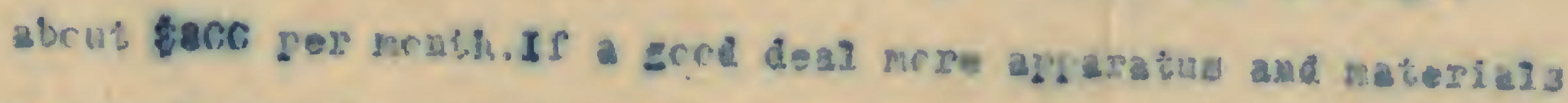

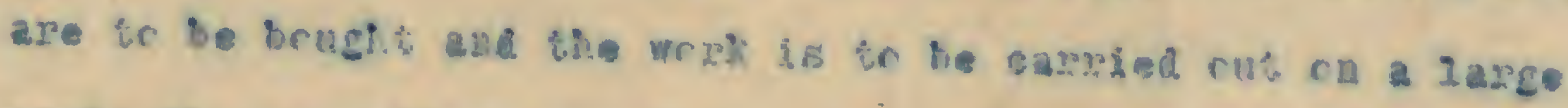

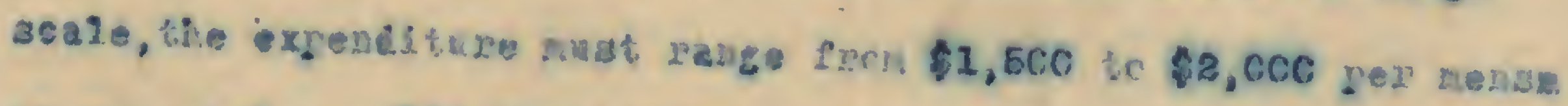
er say at least $\$ 20, \operatorname{coc}$ frr the gear.

9.

I binh it is agreed that bis worl shrnid he ccerdi-

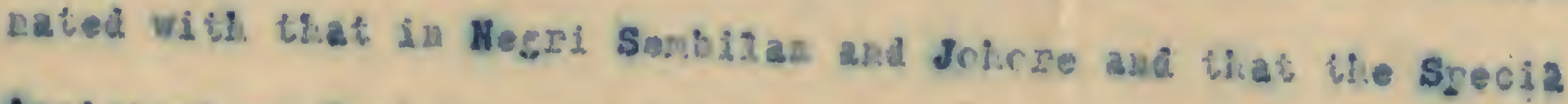

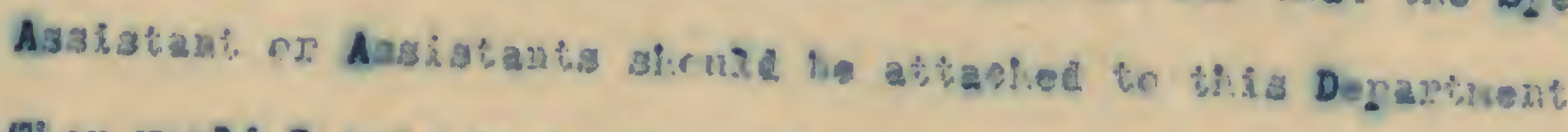

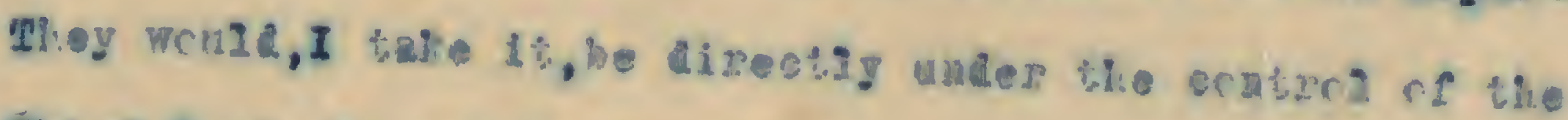
chlof Agriculcural I dsyecier hore.

10. It hay be neceasary to introluce 2egialation on the

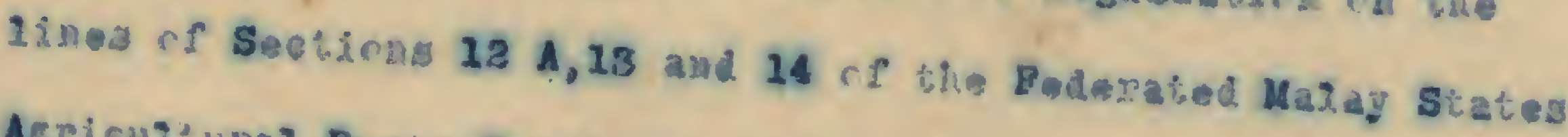

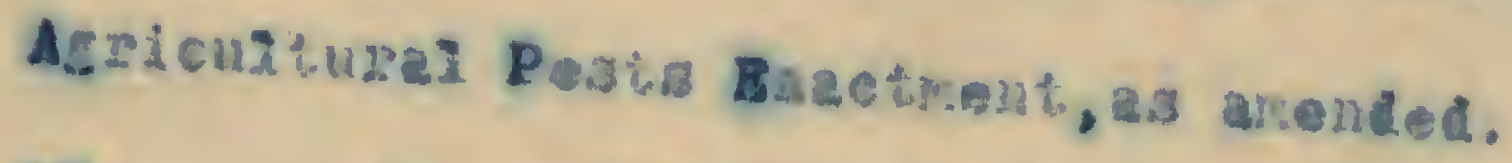

11.

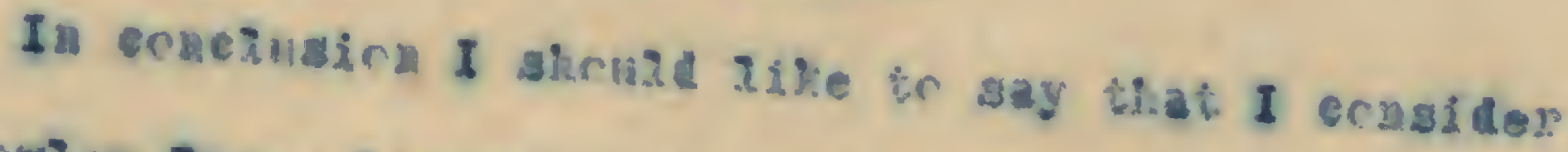

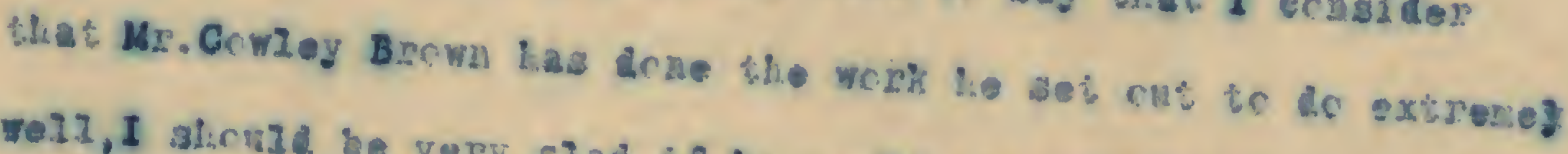

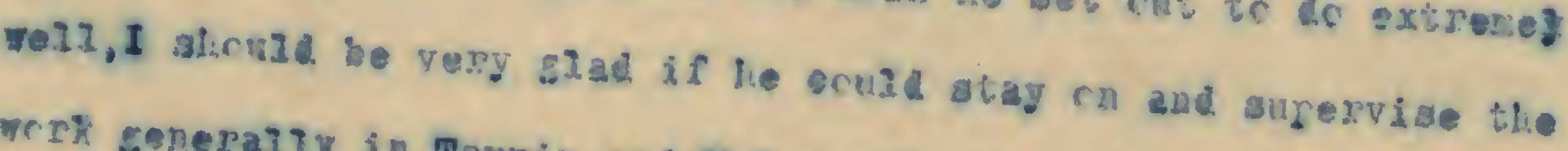

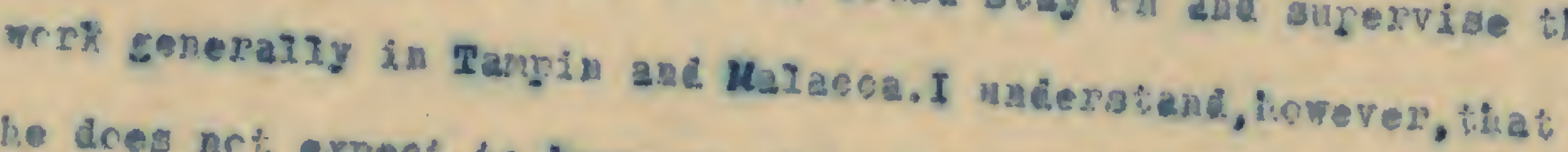
be dces nrt expeet. to keer on wibh blls werth and that it will be 


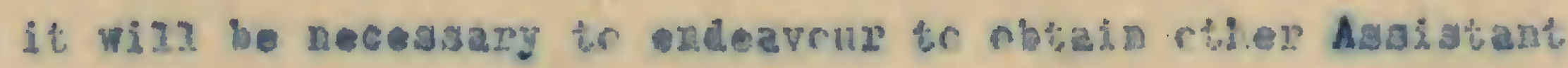

\author{
I lave tice

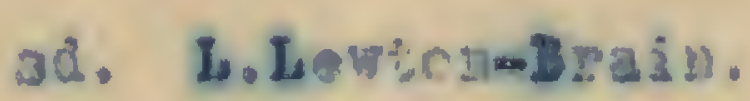 \\ Directirs
}

Tre Uner Secretary

Bederated Mazaz $\mathbf{3}$ bies

Kuมะ burgu? 
R.M

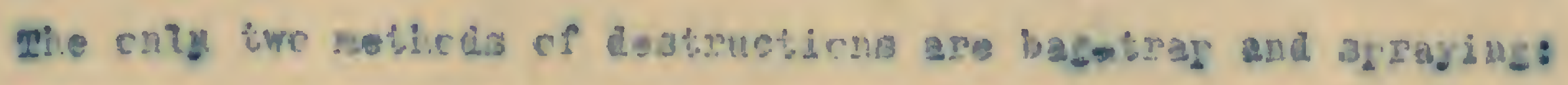

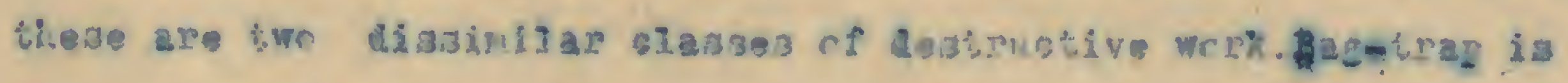

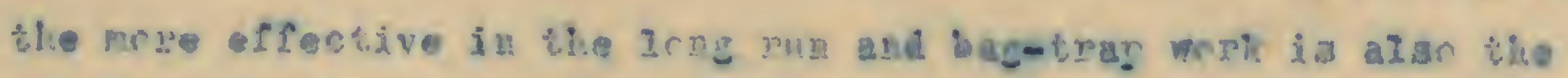
soto grachical Rebicd. Bag-tran wrot ia easizj gictod up by natives

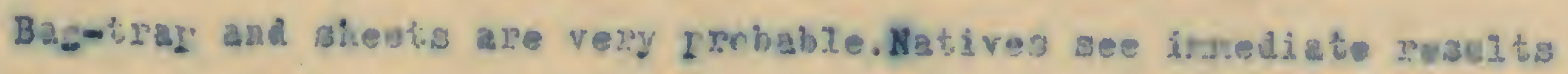

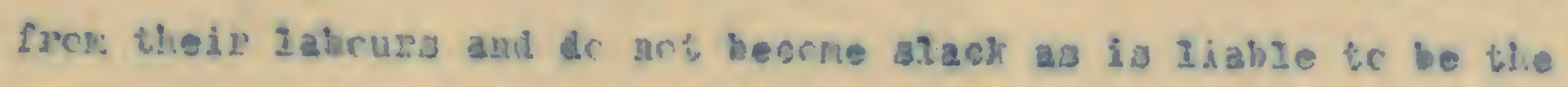

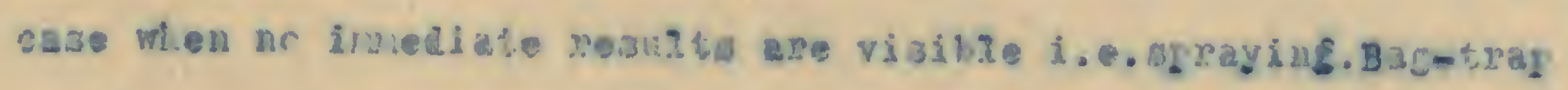

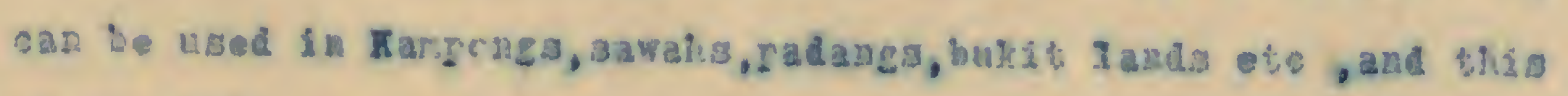
is net rike arraying a work wilde has to he ennfined to certain lecarilies.

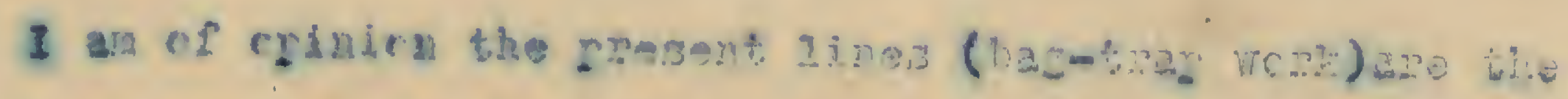

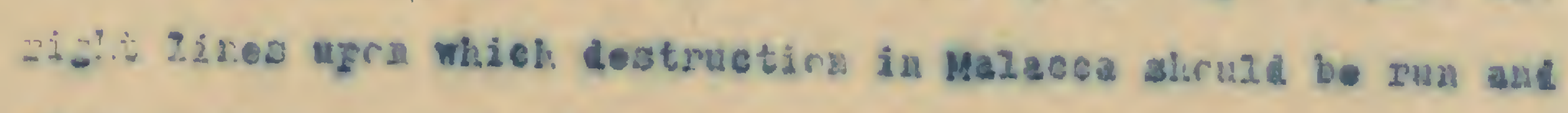
that greater contro of Incwatis thas rbiaired at gresent can be ganod betier by oxtonding the gresent aysten thas by inucratine aprayinc.

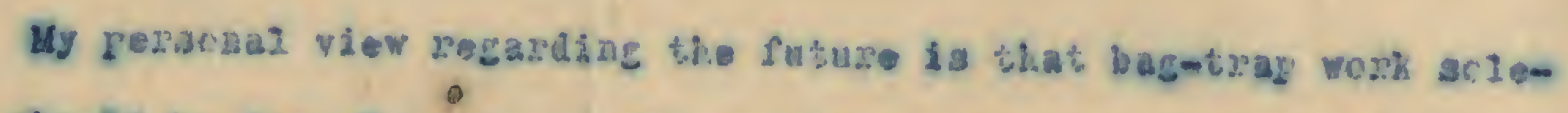

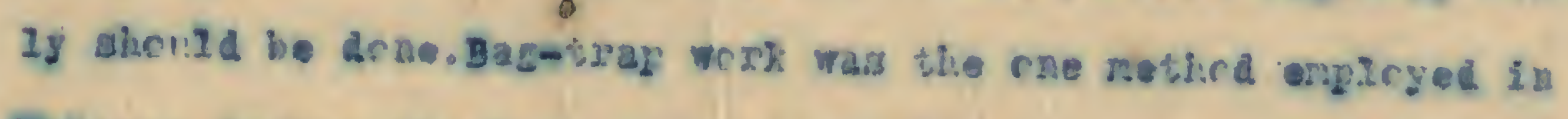
Malace during the tast year, h. ofweive morntho

The rote and extensicus for 1915 ancunt to \$10,260. This is

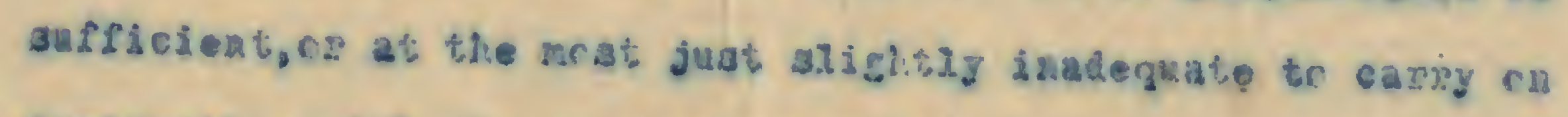
destructics with the present labour forc and arraratia(bag-trags) unil the end of the year, but is inanficient if syraying is begun this year as the balange $\$ 3,157-26$ as at oct 1 st.1815 of the \$10,200 ia toc litcle to aldew of arraying being done cn a acale carabie ef alcwing erce reaultis aro arben crmmencenent.

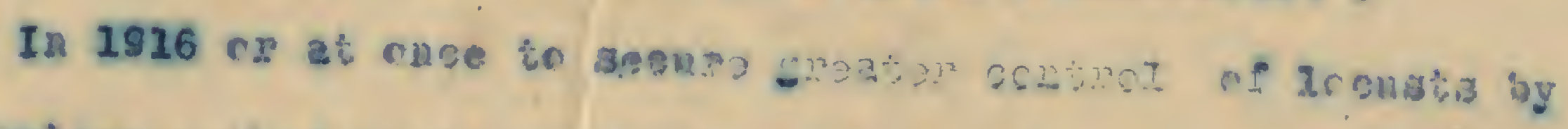

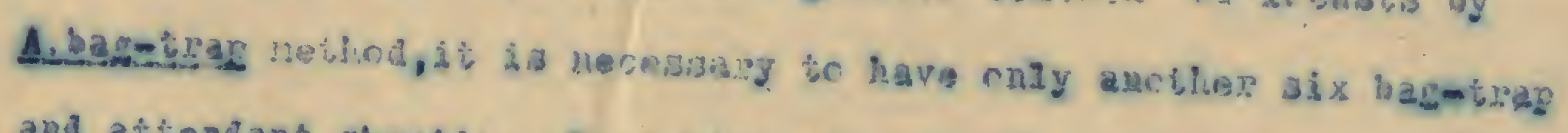

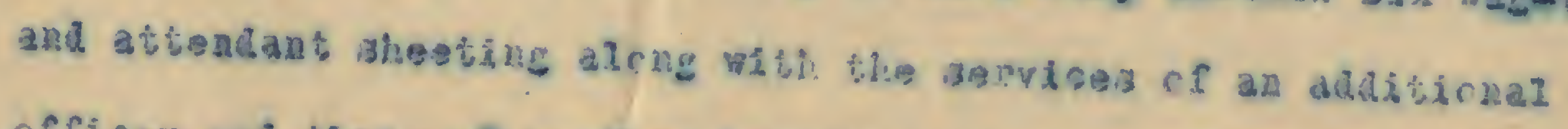

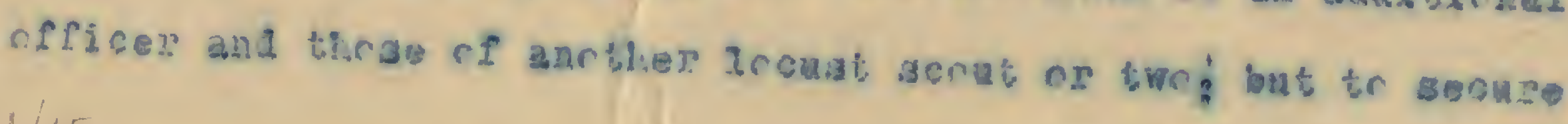




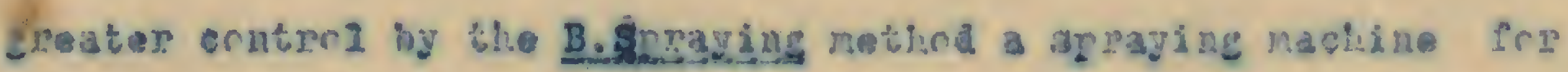

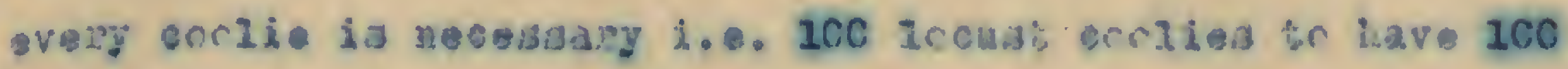

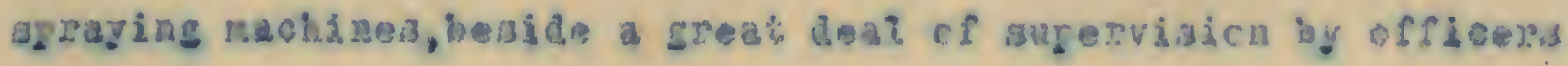

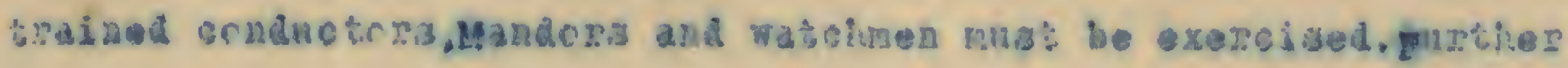

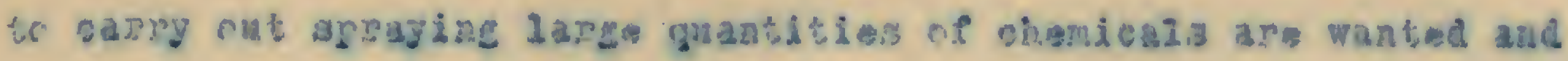
much the is cocuried by inverbigating ccrganaticn olaims male on

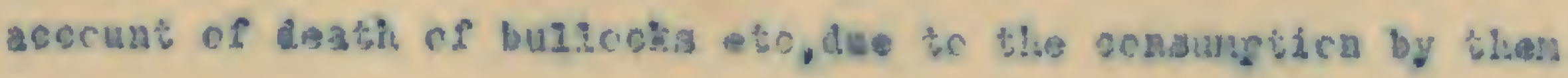
of grasis etc growing upon the sprajed (roimoneh) arad.

Sngaying.On the ccesaicn I lave seen spraging anse in Wegri

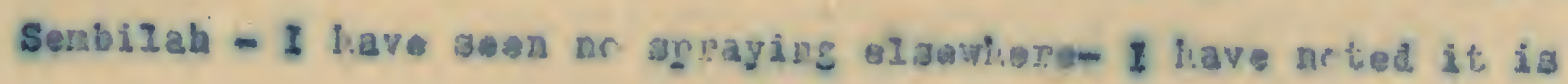

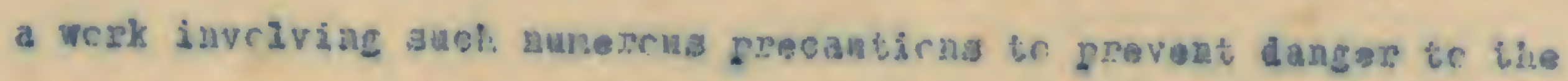

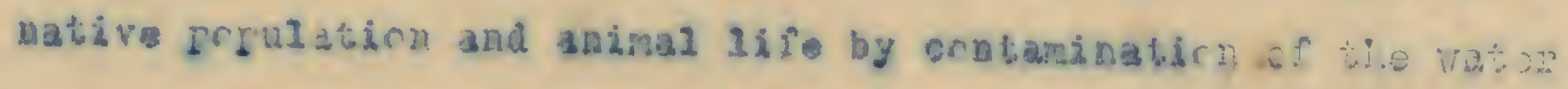
ztan?

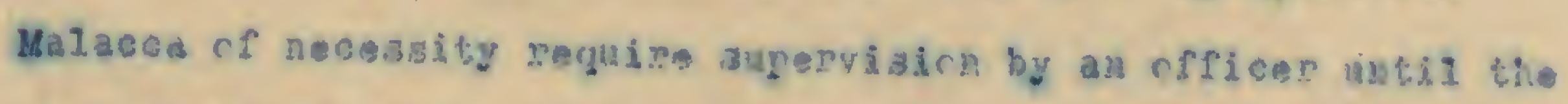

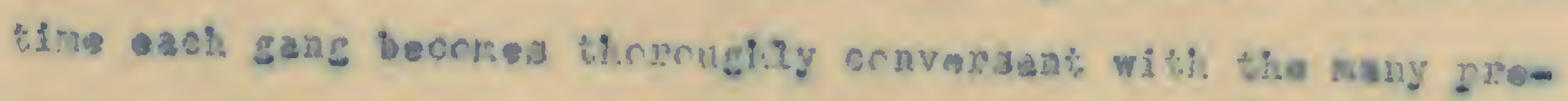

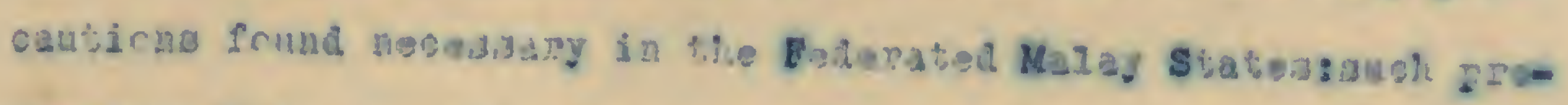

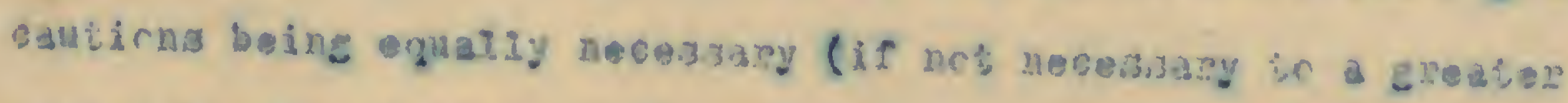

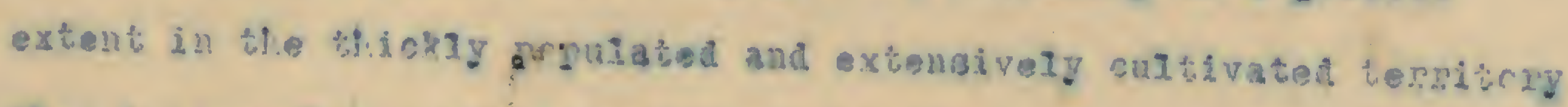

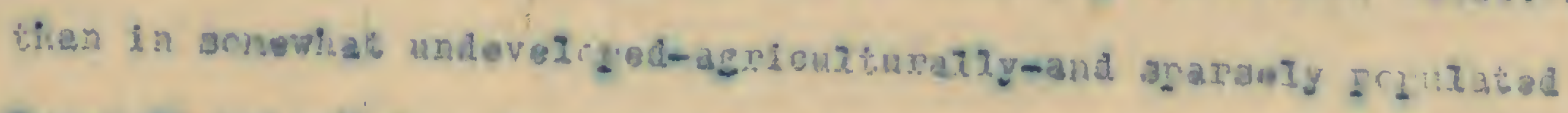

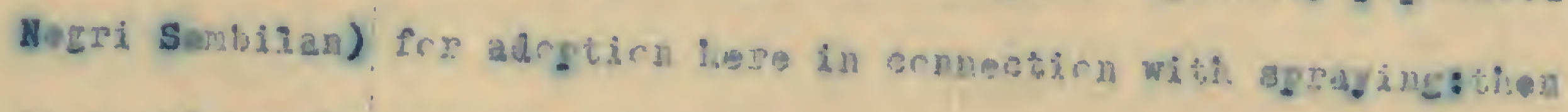

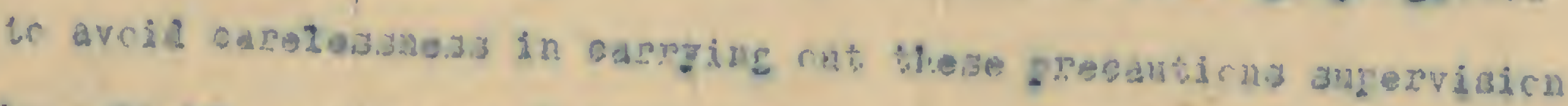

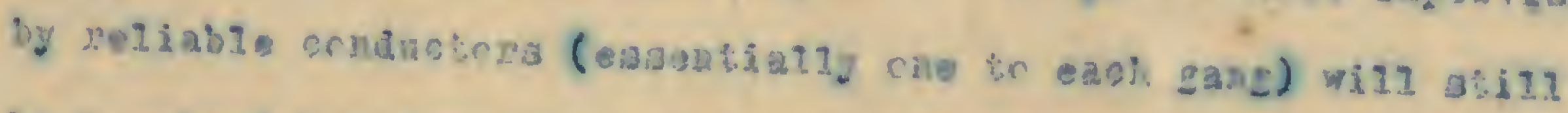

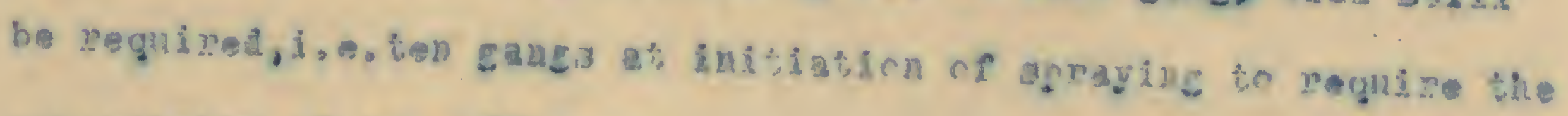
supervisirlis of ben officera.

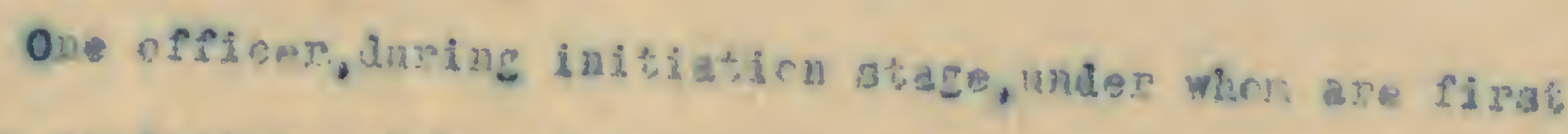

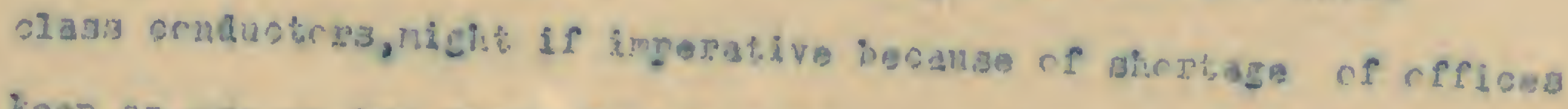

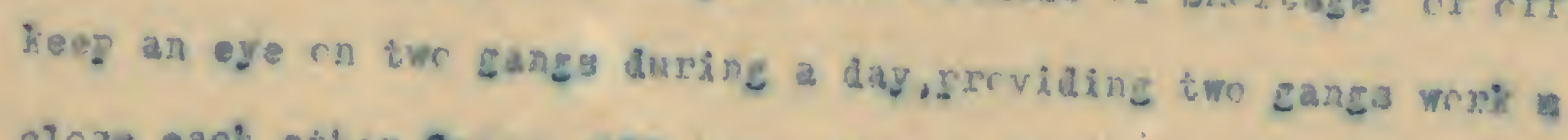

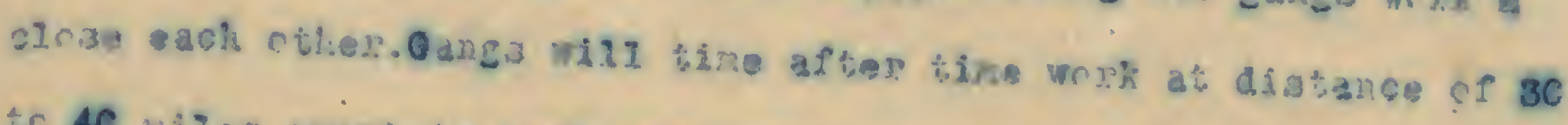

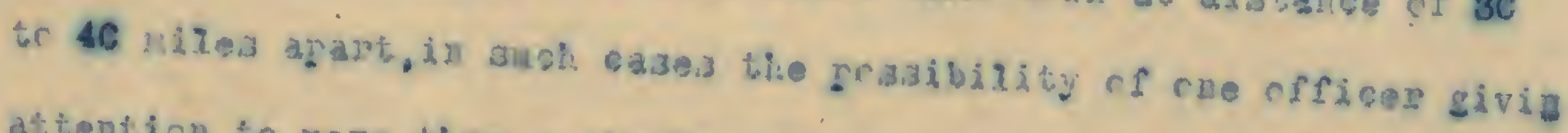
atteaticn tr repe than a angle sang in cne day is eziminated.

Tiese ar. ny view. 
Derantinent of Agricutsure

\section{Bederabed Malay stabes}

Kua? Lurgur, Are.1: Sert. 1815

Batinate of the Expenditure for Desterying focustis in the leiag

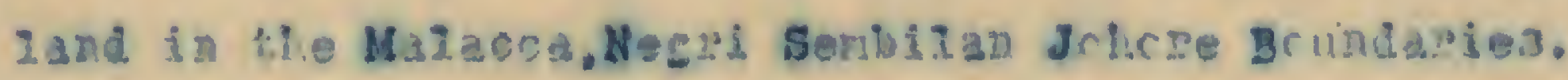

sir.

I have the frncur to gnthit herewibl. an eatinate, as deacribed abrve, in repty br grup minnte nf 2-8-25. Tl.is astimate is based on experience rbtained in the Federated uniay Statog but a

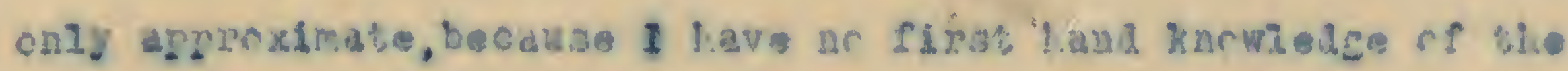

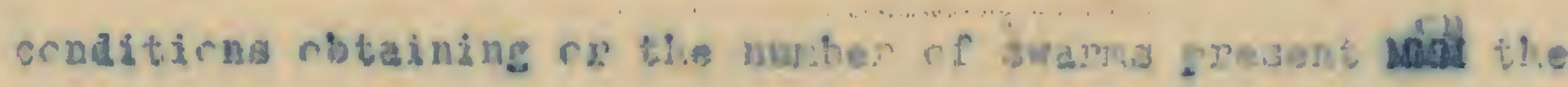
Matacen aide of bie ormbary. I lave assured, hrwover

t) thet the

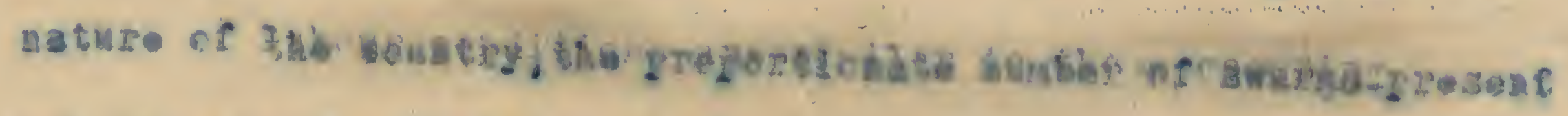

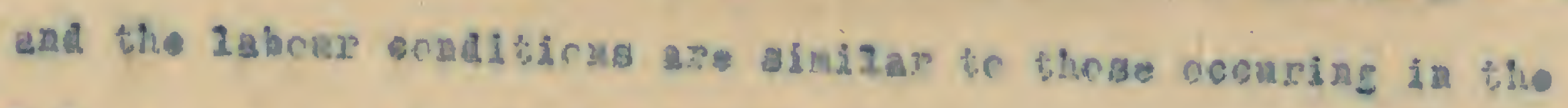
larag enuntry of the rapin astrict.

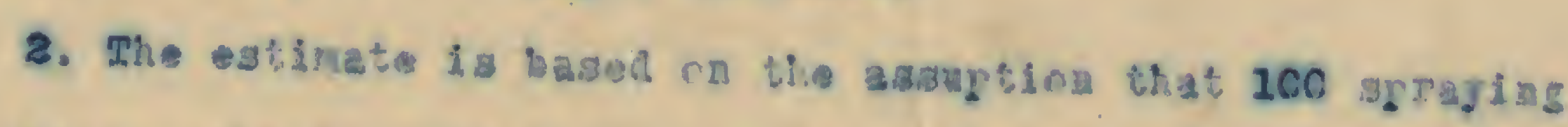

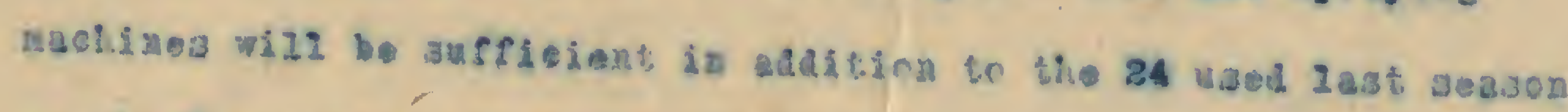

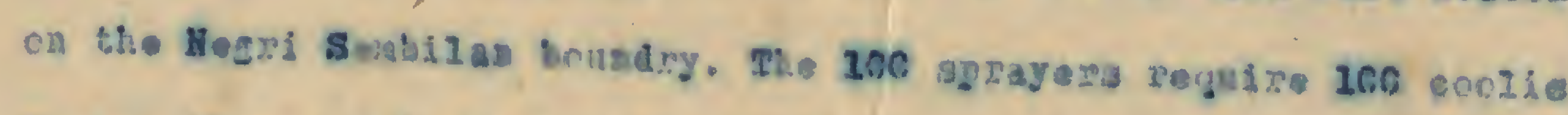

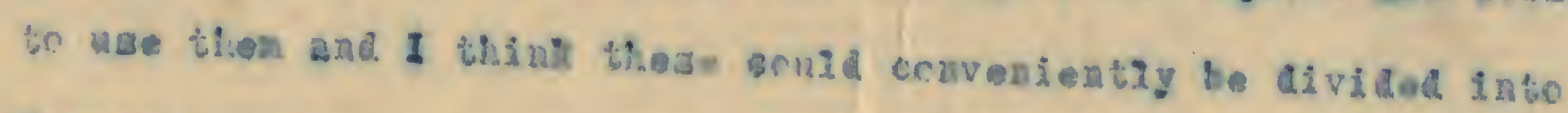

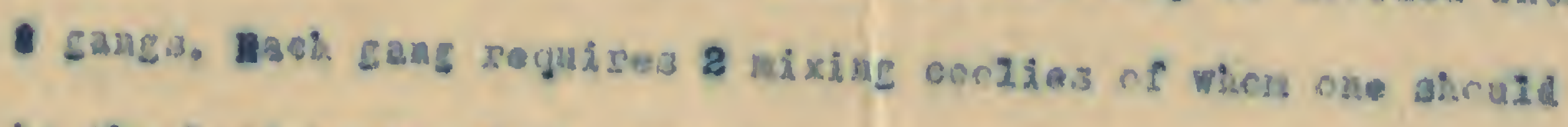
be the luad ecciz of the cure. Rigit crukuctiofo on Mandnra are

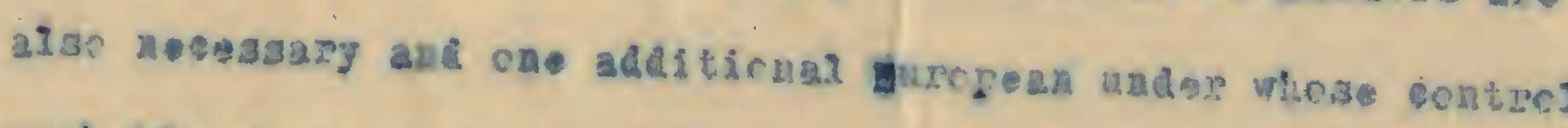

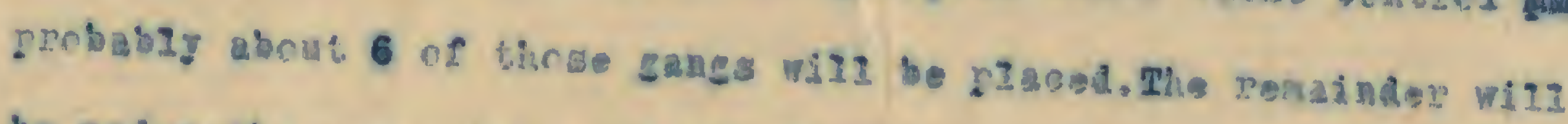

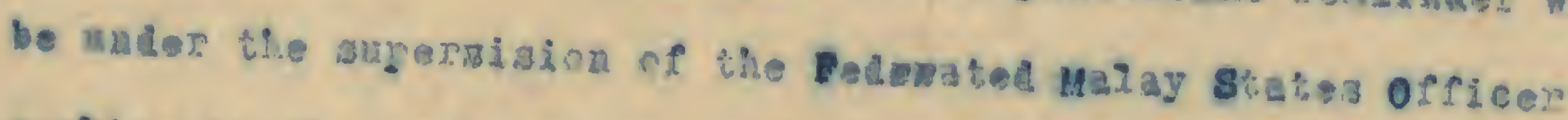

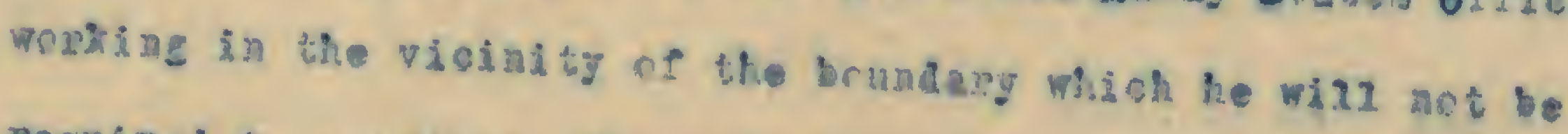
reguired tr consiles. The poritiona of condrotora and uancora

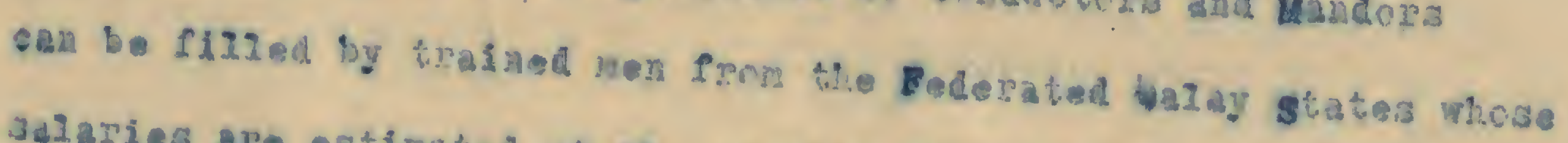
selaries ar estinated at the atrintig of whoh they aje or hate

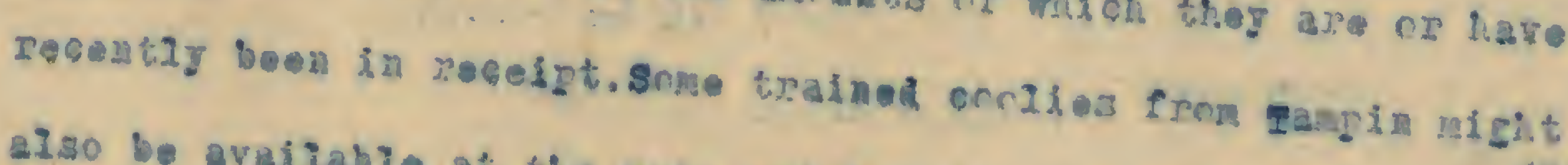
also be avaiabie at the rate put down ia bis estinato. 


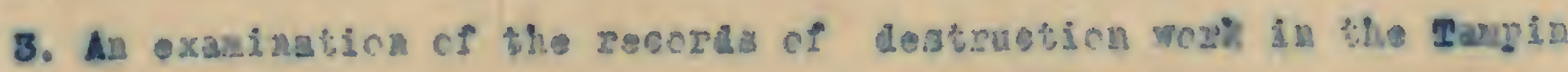

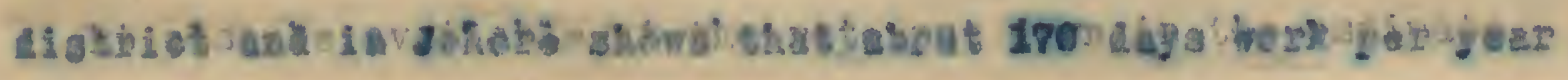

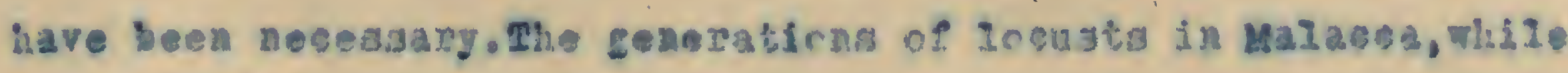

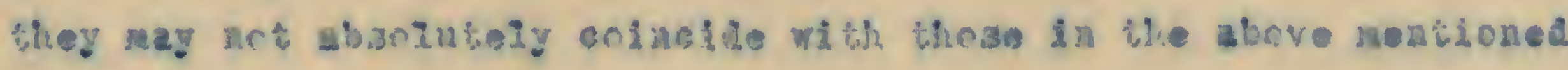

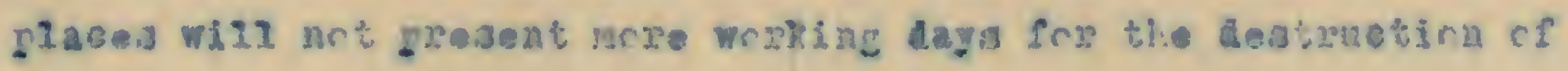
the hoprexa.

4. In ryers to reen trace of the ararna whilo the insecka are

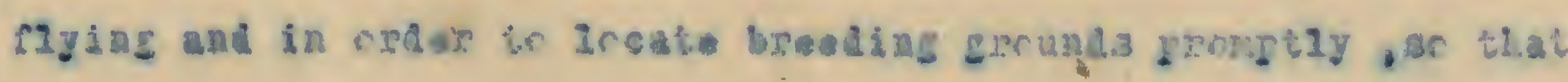

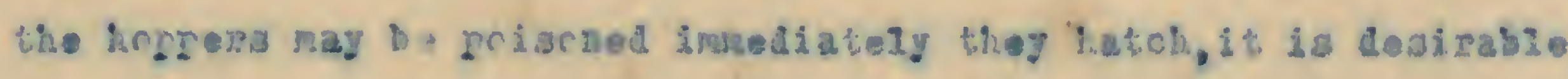
that abrus ac iscut orrlies bo micyed for the retaining 143 days which englebea the $\mathbf{3 1 3}$ wring lays of the year. 1 t has been fcund by locel expoxionos biat greater efricieacy is obialnod through the englognent of these men and at the aene tine a saving is effectol in the erst of dentruction wheh urre than grovides

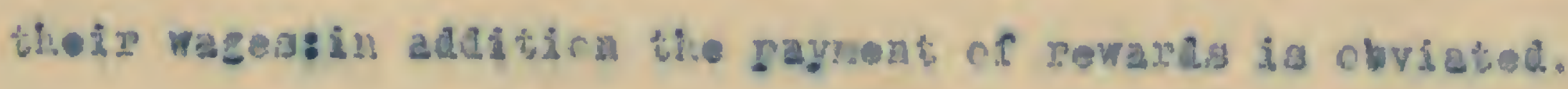

\section{BSTIUATB}

Salazieis and anconces.

1 tungean officor por nench pace $2,40 c-c c$

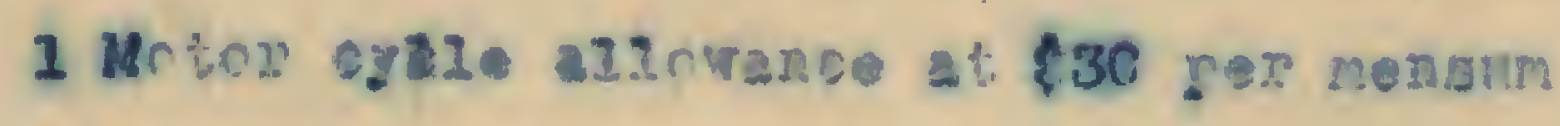
$36 \mathrm{C}-\mathrm{cc}$

1 Conevilated arrowane at 430 $360-60$ Trial gor andun

$3,12 C=c$

Labour. Berce

Inroe Cnnduebres:-

Twe at \$35 ger nenaun each ............

$840-00$

cne $a \div 20$ , $240-50$

Throe bicyere axirwance at 10 each ......... $360-00$

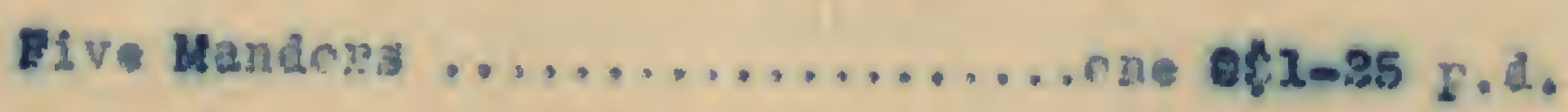
456-35

Three at 70 cts. per ag $766-5 C$

one at 60 chis. ger day 218-50 
Crobizgenoieis

\section{Grant Totas tan,cco}

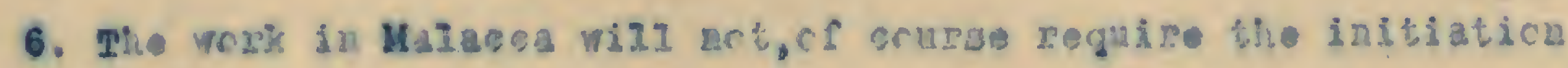

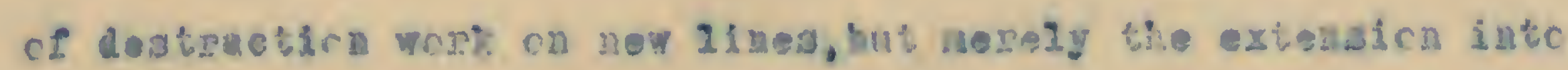

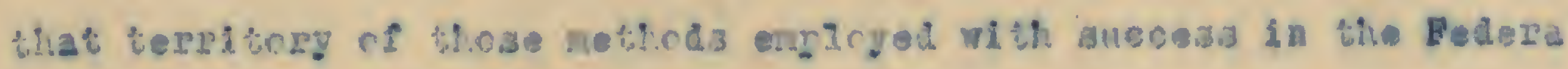

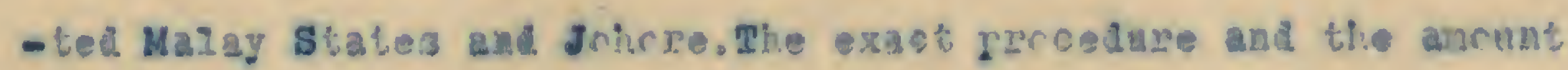
of mupervisicn deairesi. here lave been detemined by experiedce but: for wrik in Matacea the atrongth of the labrur foree is a

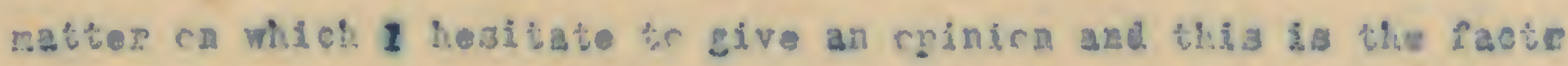
wich nust necessariag grvern the gathate.

$$
\begin{aligned}
& \text { I lave ete } \\
& \text { 36. F, W. Scet: } \\
& \text { Culef Acriculcurar Ingreotrz } \\
& \text { E.U.S. }
\end{aligned}
$$

The Dirocter of Agrieuzture

$$
\text { E.M.S. }
$$




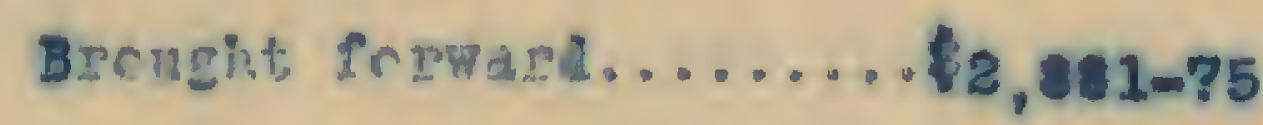

Crrizes

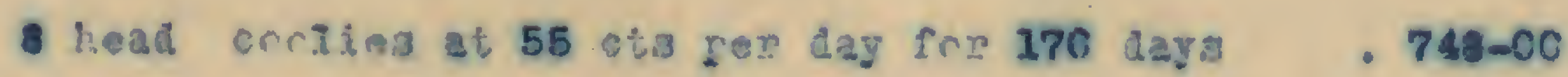

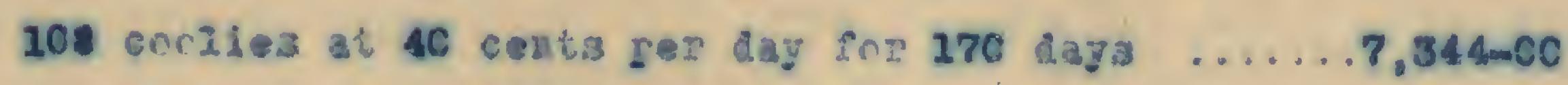

20 aerutine erisea at 40 cia, rer day fre 143 daya. 1, 144-CC

$\$ 12,117-75$

Uateriais Trangron ete.

Poison

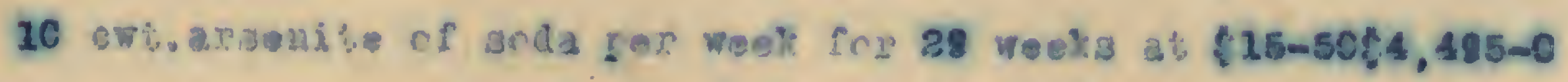
Susar

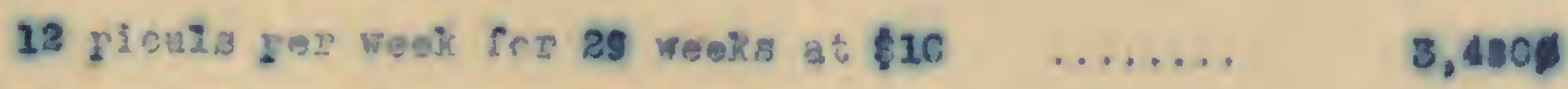

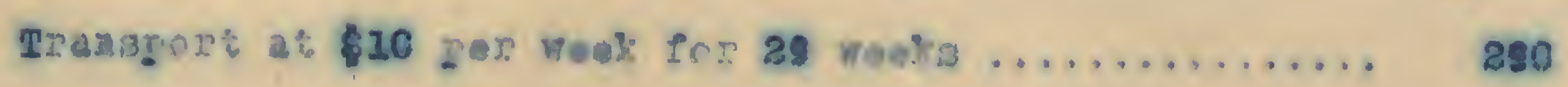

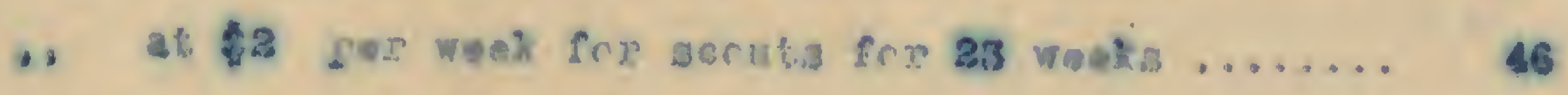

Heraing at the get keath fer 7 math.... TC

Arcaratus:-

$50,301-60$

Sleetine

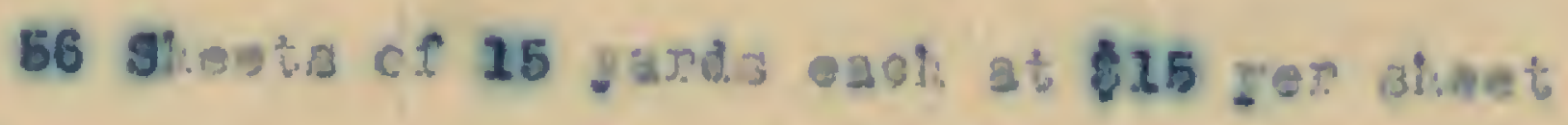

840-50

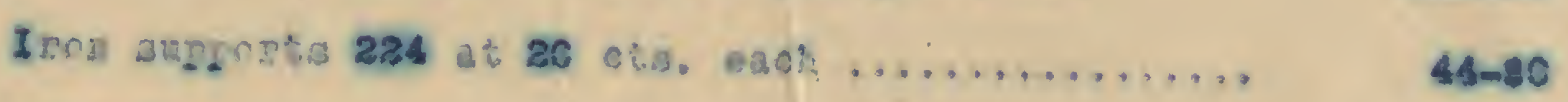

Srrayery

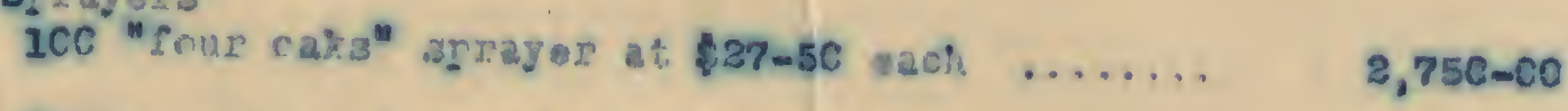

Spare garts and rerairs to abnve ............ $250-c 0$

WarAiag mósicas

25C large aize at है each ............... 25C-CC

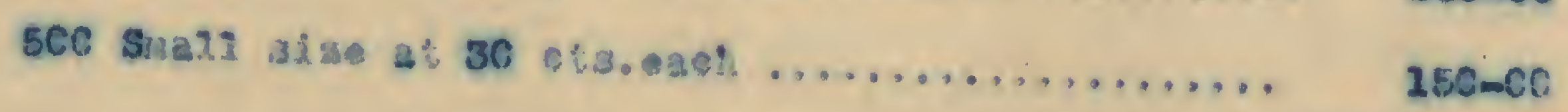


No.84 in? 2474,1973 ofpice of Direotor of Agriant ture

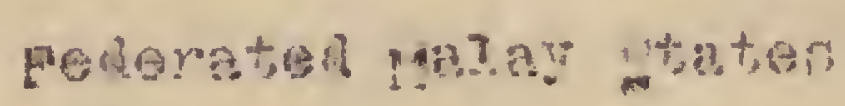

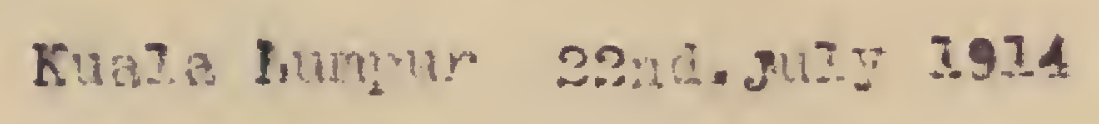

Sir,

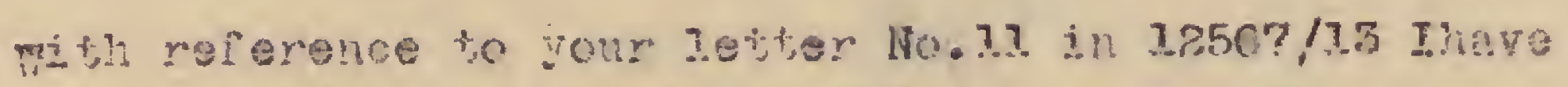

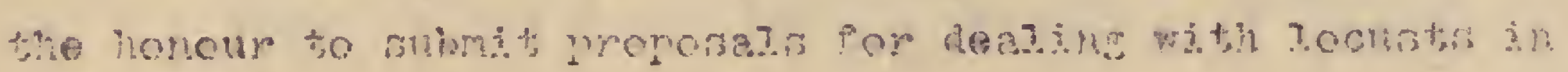

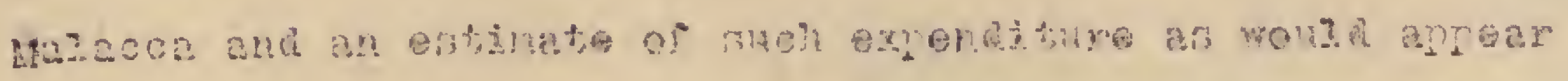
to be in! confoymity with the conditions lath down there.

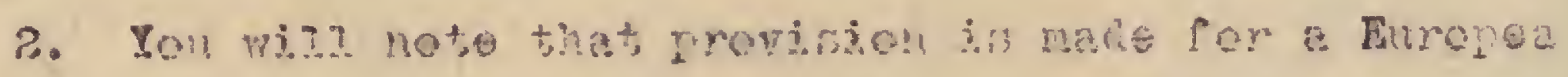

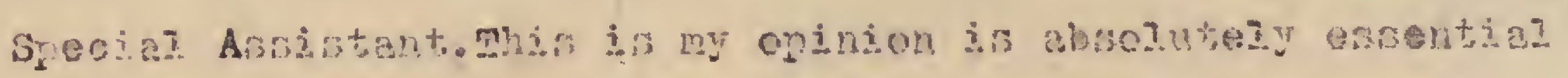

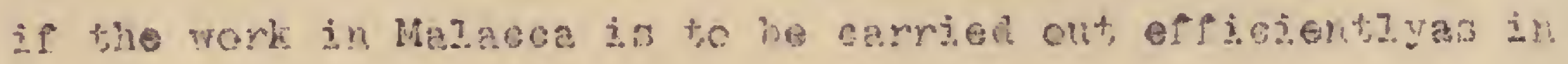

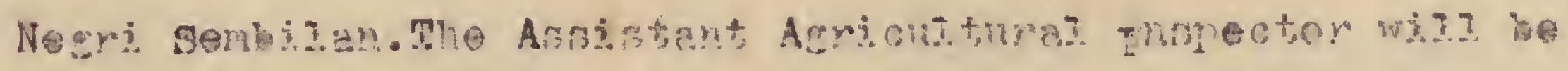

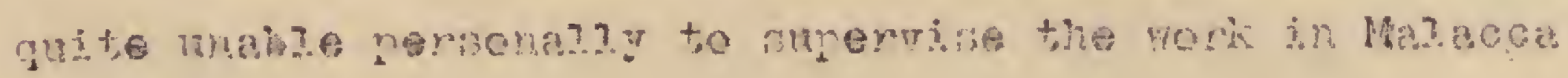

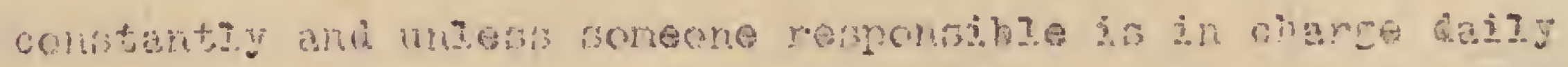

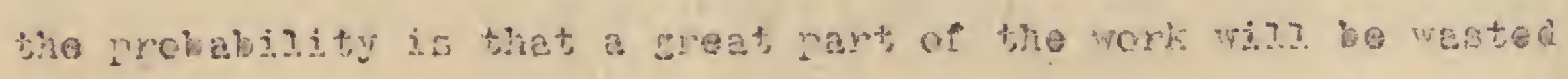

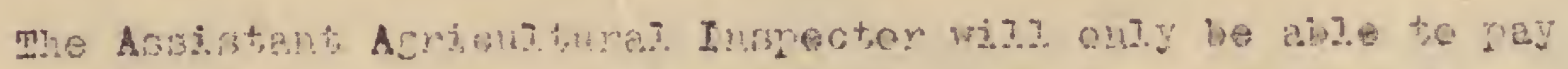
cecankene? visitin to lireot the vork.

3. T. wonk inke to point ont that the division of the

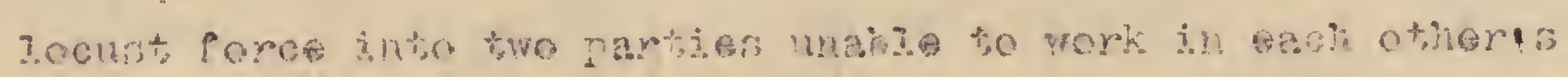
territery in uct, the nort, effective from the point of viev of socust dentrubtion.

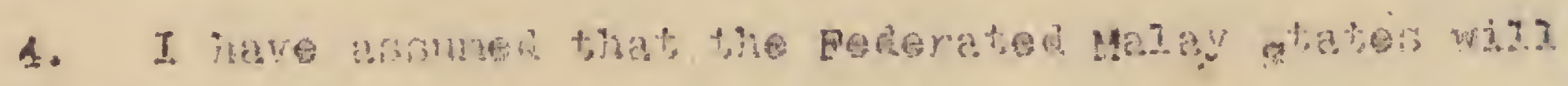
surnzy apraration and natertats.

The Under sogration

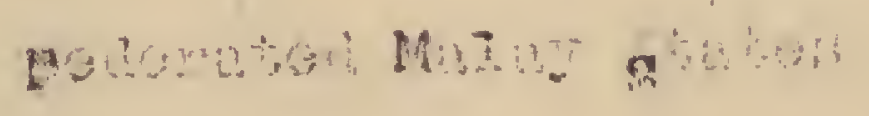

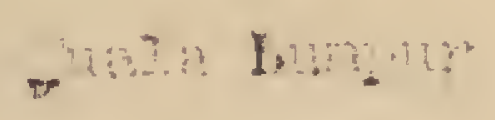




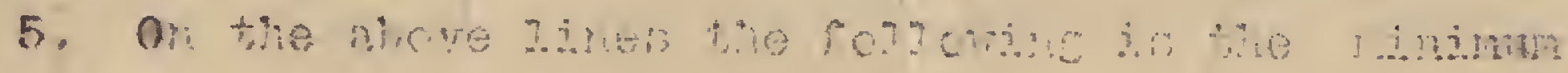

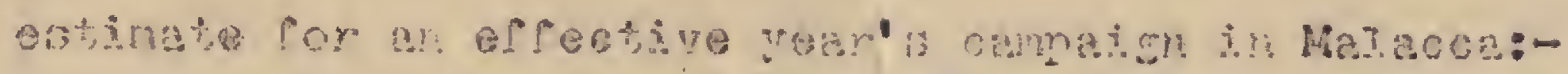

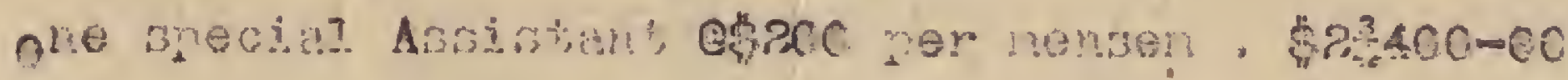

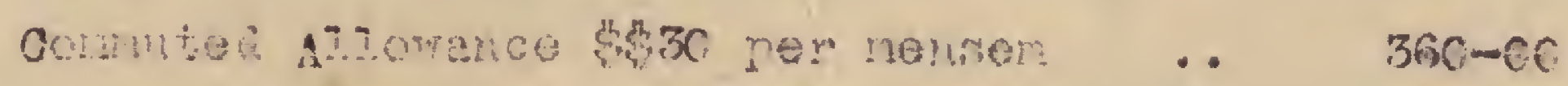

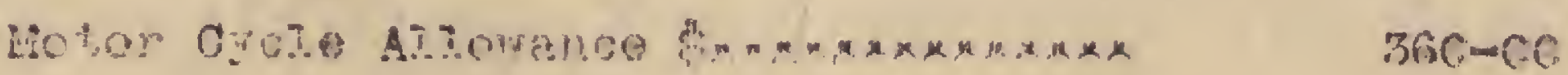

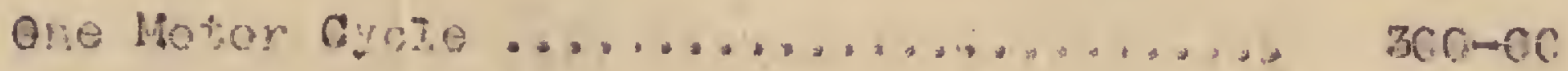

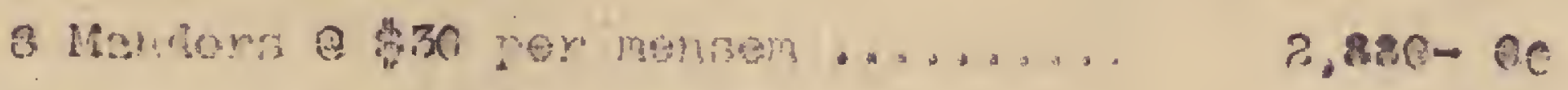

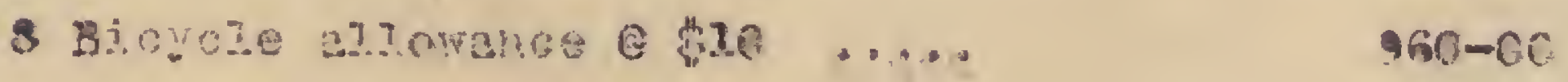

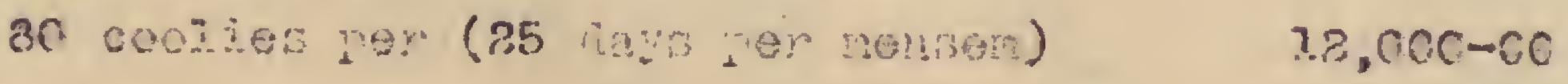

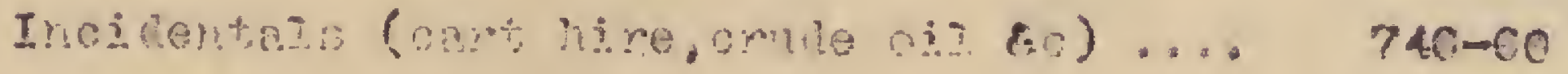
Totat $.80,000-00$

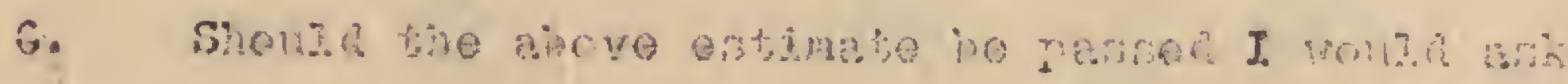

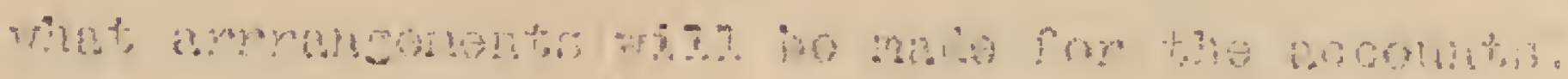

\section{I $\therefore \operatorname{arch}$}

$(6) .10 .1 \cdot \operatorname{sen}-B: 1.11$ 
No Minutes should be written on this page. A separate half $=$ sheet to be used if required. 
Keccived 2.45: 16.

21.1 .6

Answered.

L

Len parkhe is

manaed of himel

prat

-

ss zepos

acas $h$

latkang wabio on on

sich $x$ a is ur vick

have smo foncel ay

frimin?

say

nees

Centhlan

fud

$3 n$-be Manies 
8

S munct as we have.

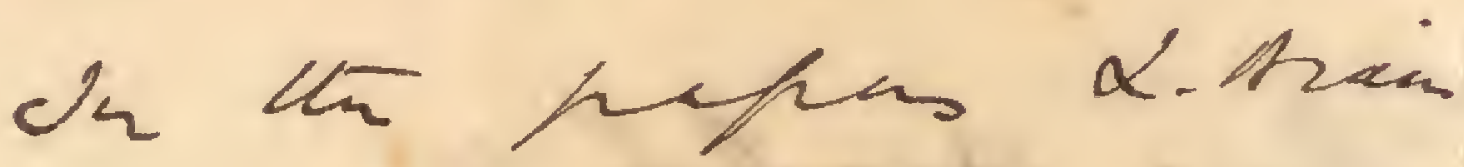

smat melick t

hen $\$ 20$, w . Th:

is 5 mack. Michell

haned tow,

hohith, thinh.

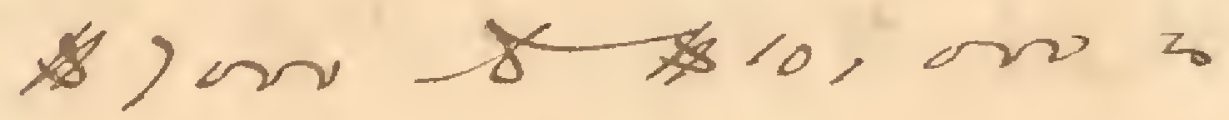

niz ides - Wat 


\section{Botartso Gormans, \\ Gingerers, \\ $34 \% 1 \%$ *atuery, 7976}

Doan Mr. Woteromtats,

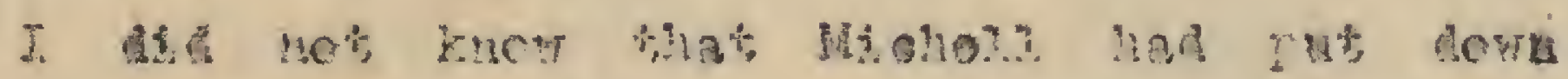

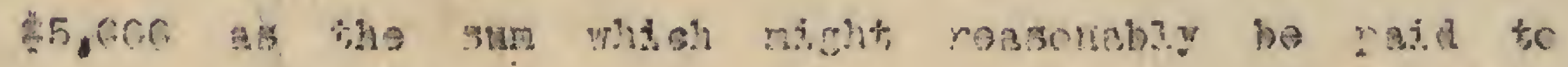

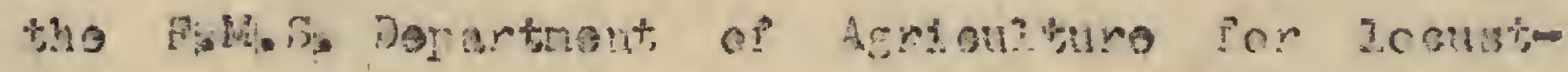

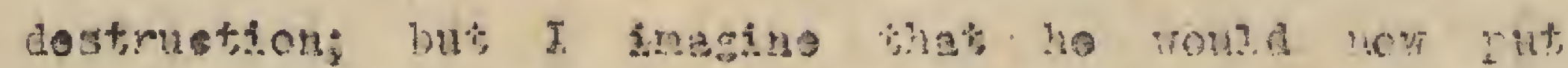

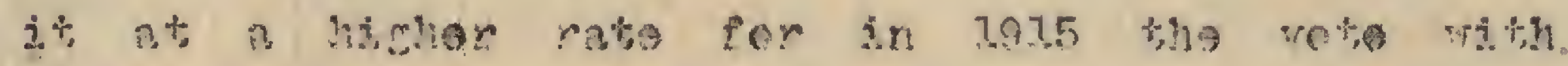

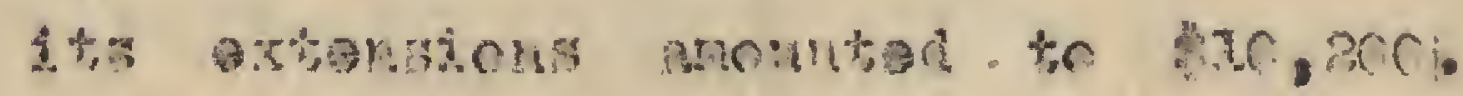

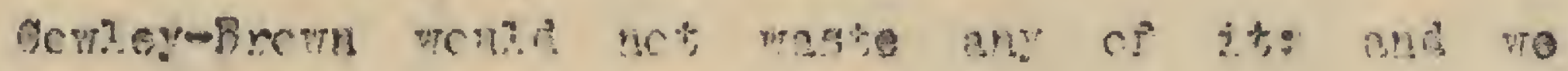

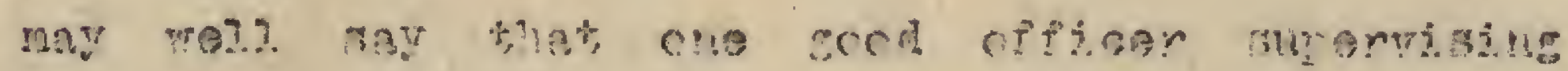

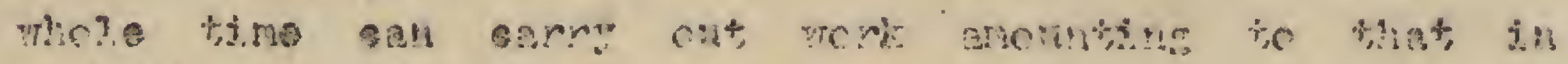

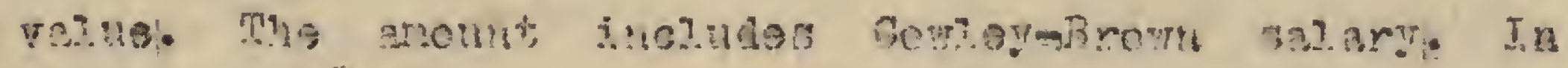

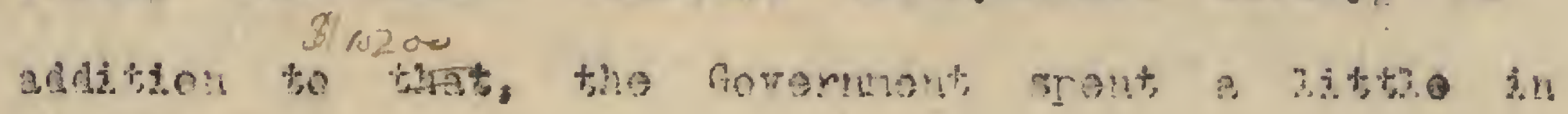

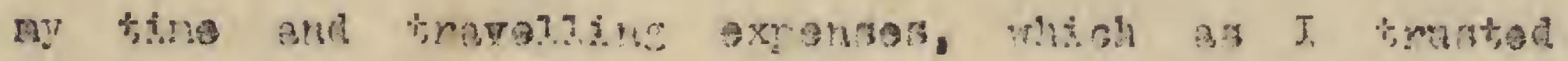

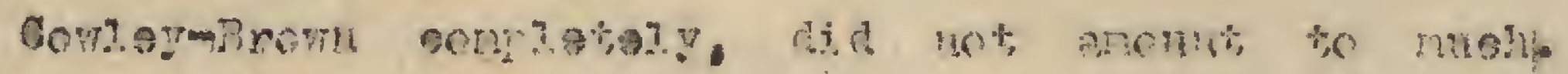

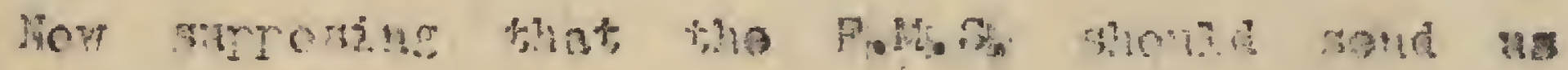

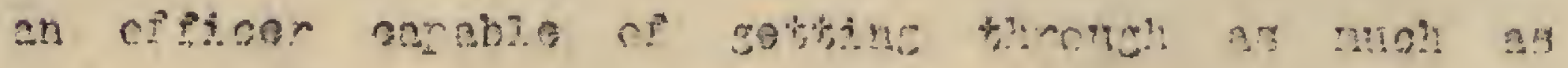

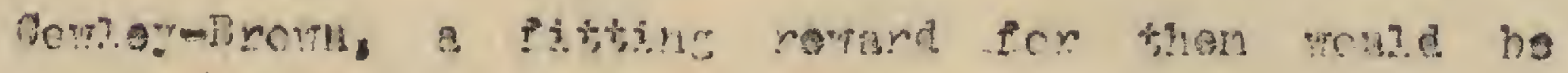

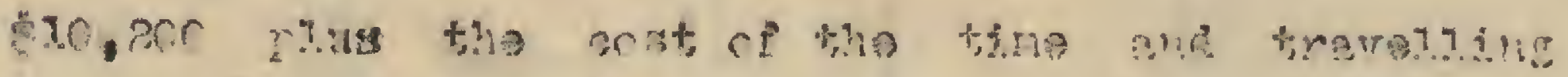

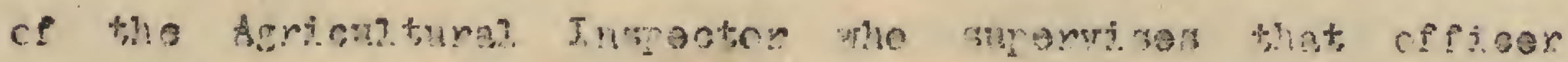

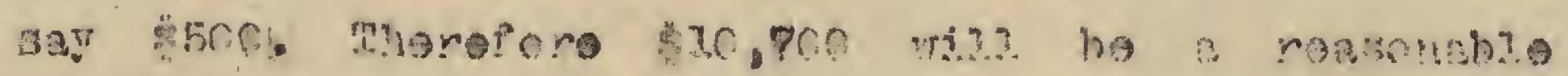
remard.

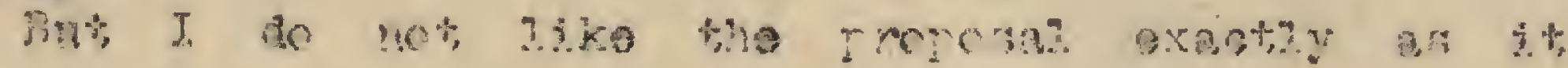

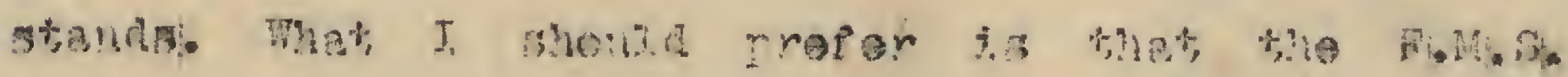

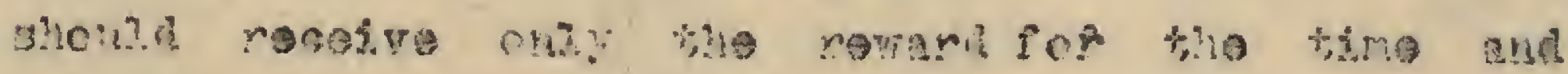

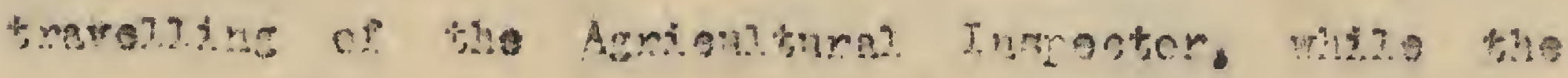

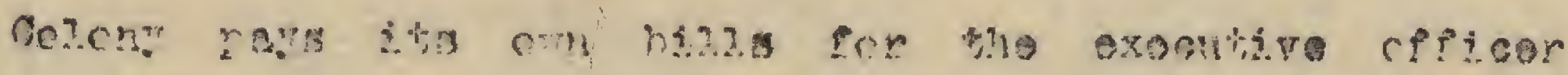

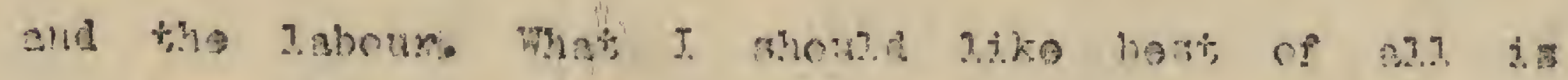




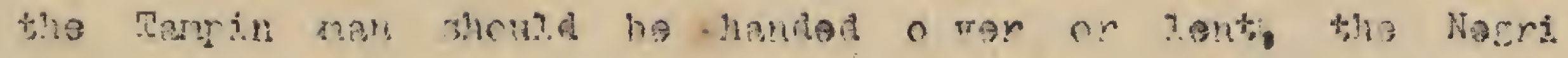

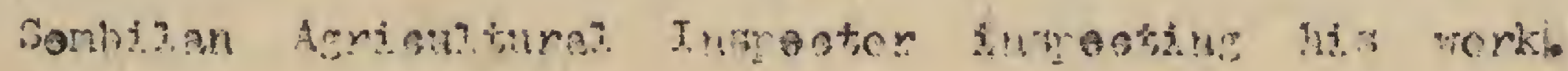

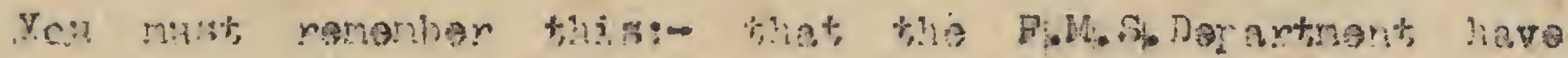

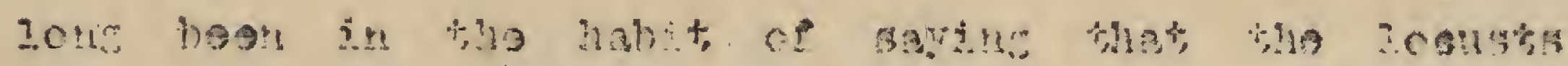

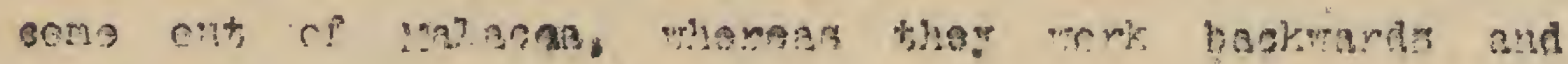

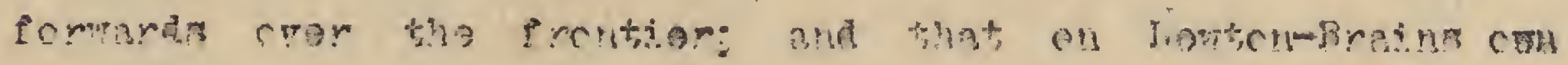

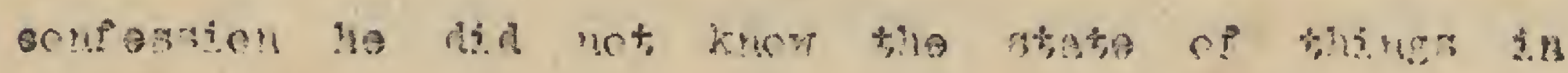
Ma?asco. Therefors ho tat, dom and askal for to mol

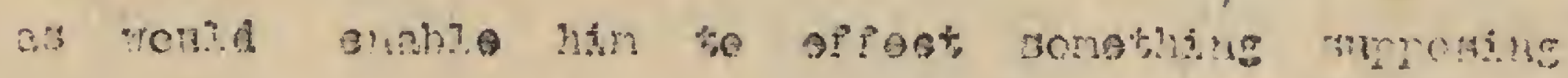

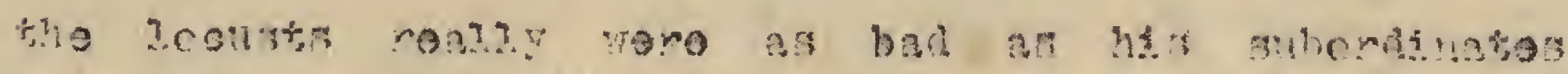

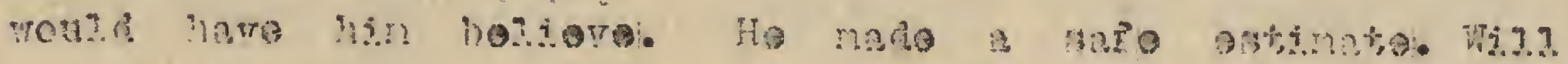

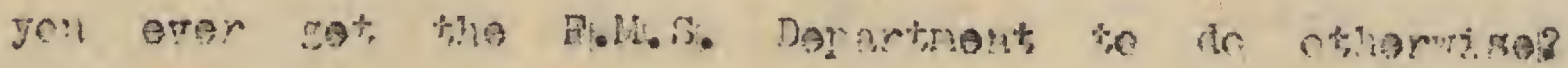

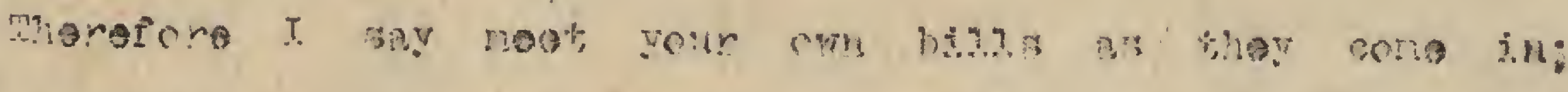

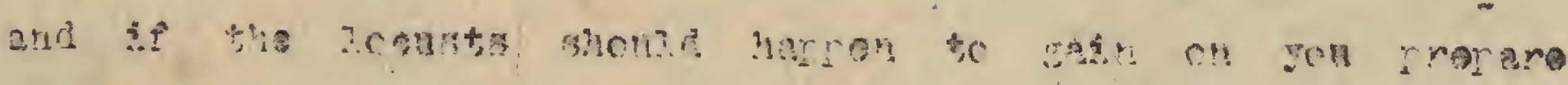

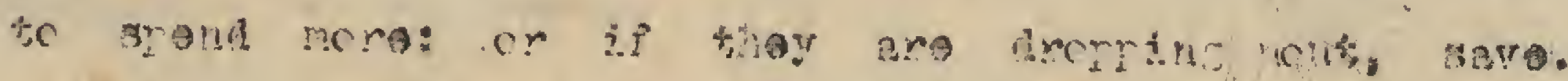

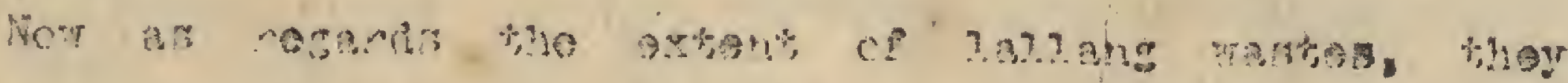

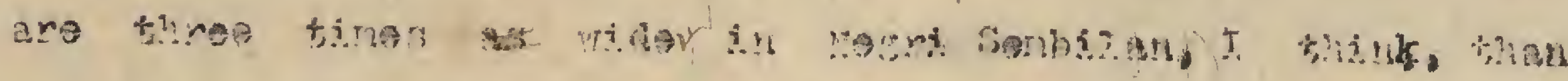

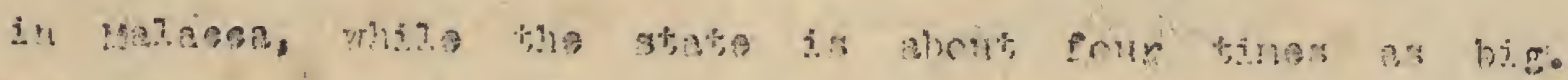

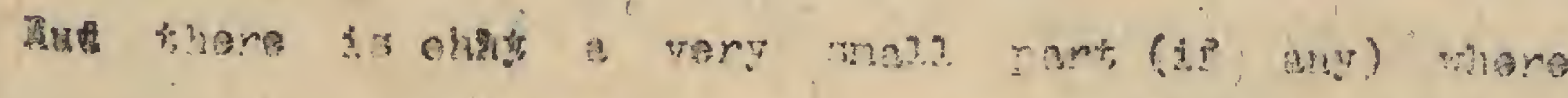

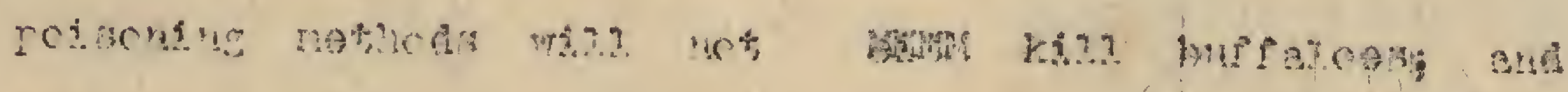

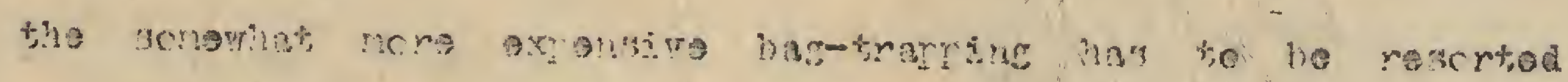

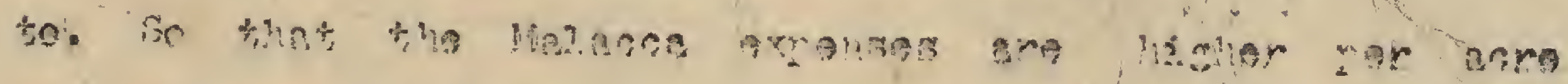

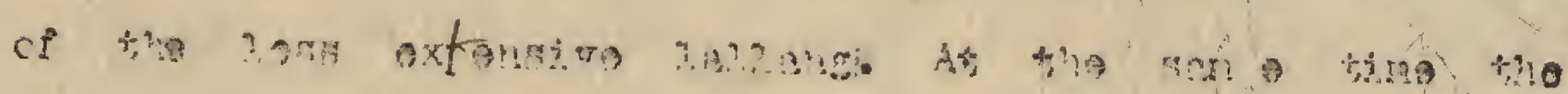

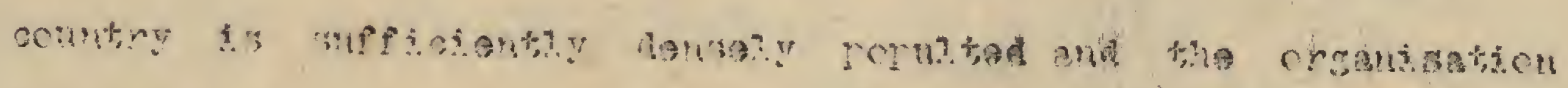

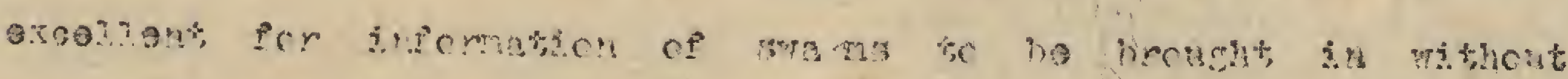

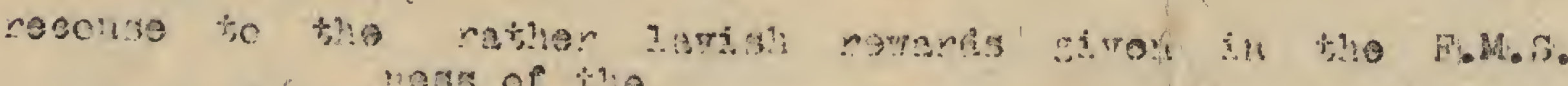

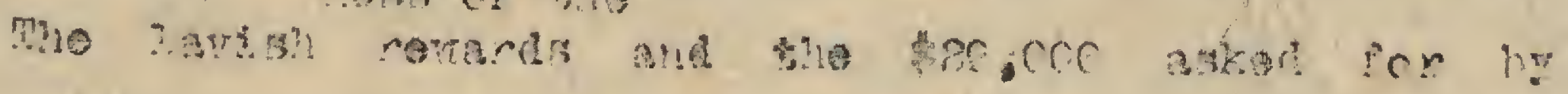

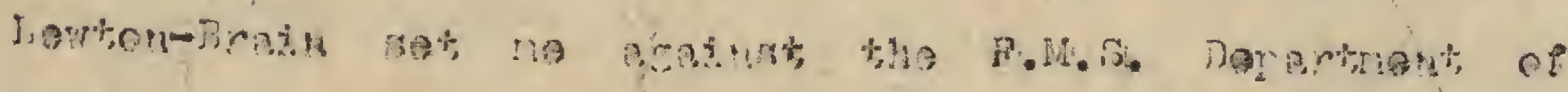

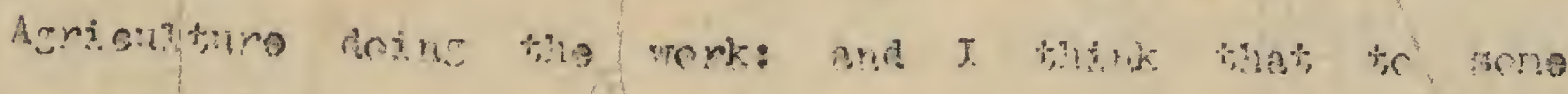

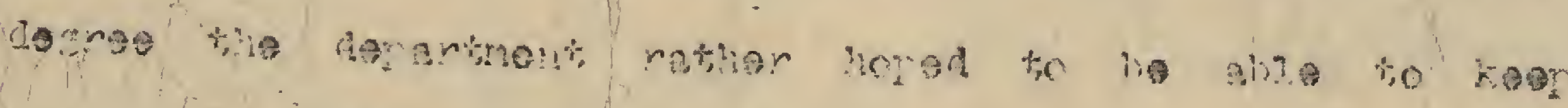




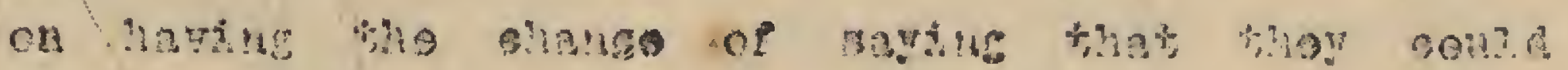

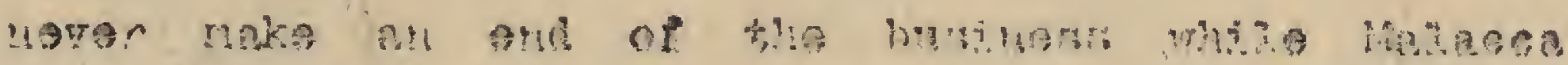
mretontas thiam.

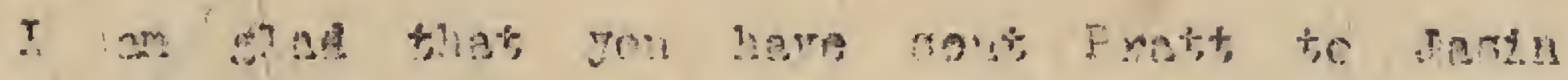

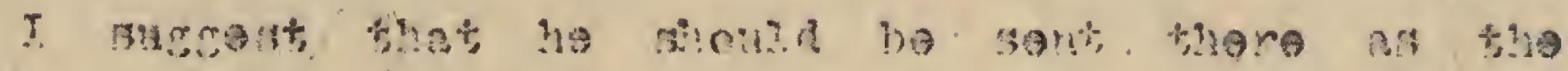

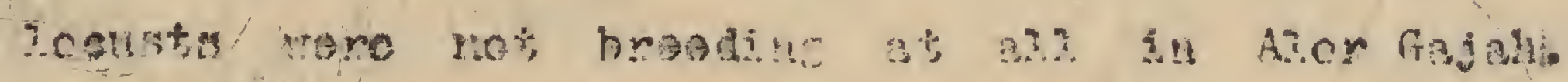

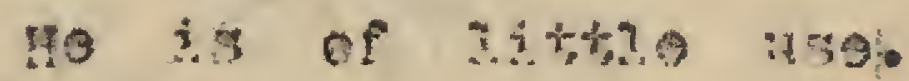

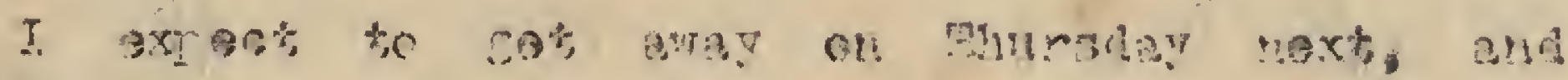

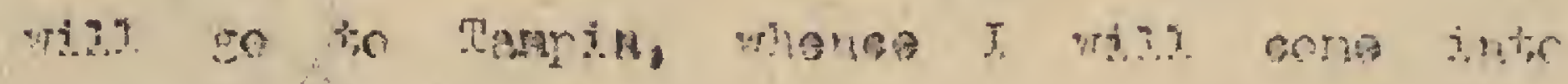

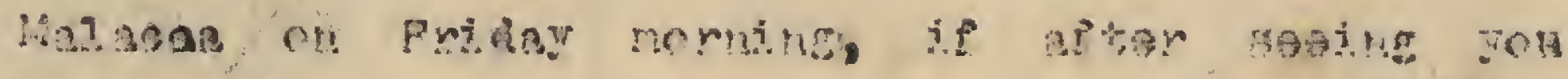

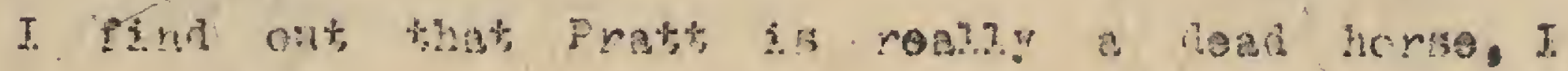

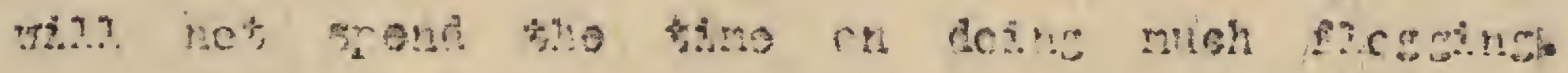

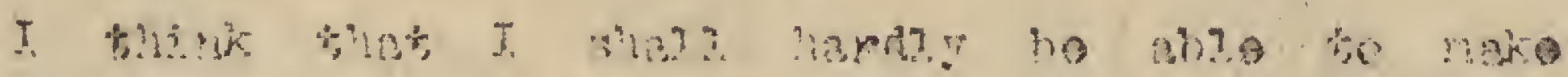

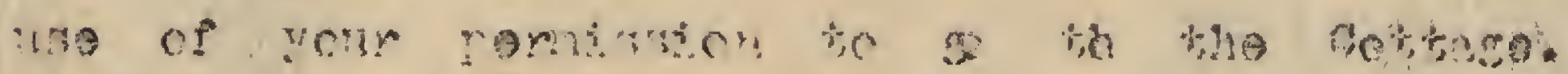

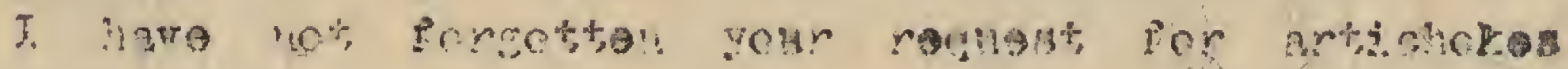

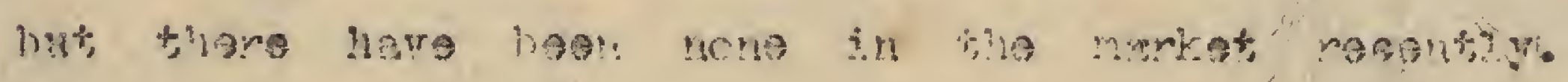

vours Bingerog 
3

sil tom?

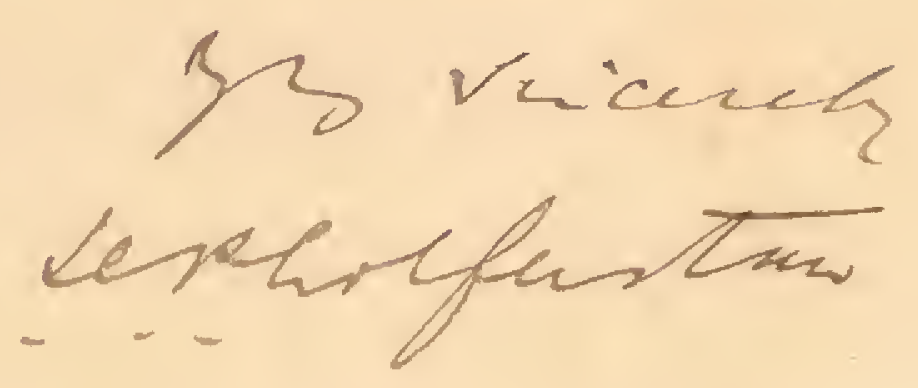

B8.1/27 


\section{O.A.B.}

Telegrapbtc Hosress:-

"Secretary, Singapore."

It is requested that the following number be quoted in the reply to this letter.

MAL AY AN 7843/25.

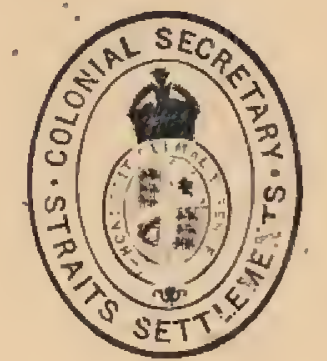

Colomial Sorretares's (Bffice,

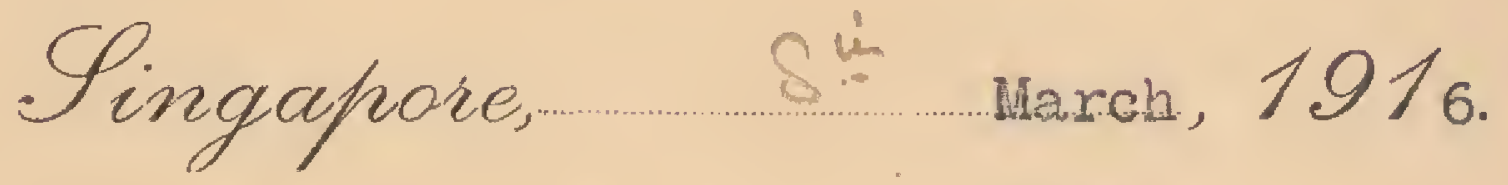

Sir,

With reference to your minute of the 19th January, 1916, on Colonial Secretary's Office correspondence No.7843/15, I am directed to forward for your information the enclosed copies of a letter from the Under Secretary, Federated Malay States, and of my reply, on the subject of locust destruction in Malacca.

I have the honour to be,

Sir,

Your obedient servant,

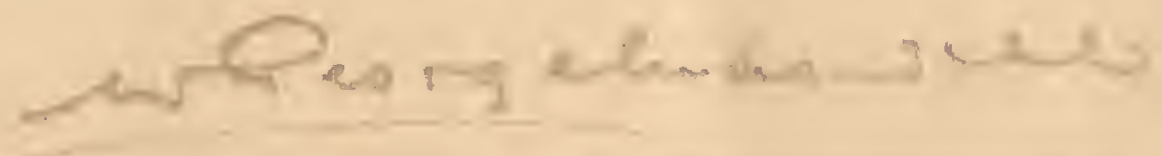

Ag:Colonial Secretary, Staits Settlements.

The Director of Gardens,

$S I N G A P O R E$. 
COLONIAL GECREIARY SS ODEICE, SITGAPORE, Bnd $150 \mathrm{ch}, 1016$.

Holiay $7823 / 15$

Sirs

In reply to Jour letter 5 in $6327 / 2915$ of the

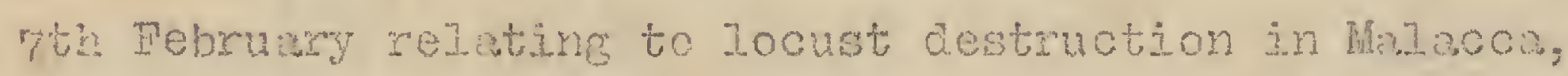
I an directed to inform you thet this Governnent agrees to the nronosals contained in the monorndum prepared by the Director of Agriculture. Federated Malay Stotes, and that a rote of 320,000 wi11 be twen to cover the estimated expenditure.

I have the honour to be. Siris,

Your obedient serront, (Sa). W. Georce Lawe?], As:Colonial Secretary Straits Settiements.

The Under Secretary, Federated lasiay Strotes, KU A I A I U If $\mathrm{P} U \mathrm{U}$. 
No.

5 in $6327 / 2915$.
KUAI, LUILPUR,

TEDERATED MALAY STATES.

7 th Tebruory, 1976.

Sir:

Reforring to your letter No.7843/15 of the lath Janumy, 1916, on the subject of the task of locust destruetion in Molacen, I an directed to forward herewith for -your considecation a copy of menormoum propared by the Director of Agriculture, and to sey that is you agree to the proposals contained therein, the Director of Acricuiture, mill be sstea to settle detajis with tre Resident, Hajnca.

I hove the honour to be, Sir, Your obedient servant,

(Ba) H. Hocirray, for Under Secretary, T.IR.S.

The Honourable, The Colonial Secretary, Surajts Settiements: Sing ap ore. 


\section{Ifemorandun.}

I propose that the wirole Expenditure for looust destruction in the B.I.S., the Colony and Johore for the current year should untim metely be divided between the different Govemuents in the following proportions:- I.M.S. one haze, Colony one quarter, wa Johore one qurter, with the proviso that the contributions of the Colony and Johore shoula be inted to a maxmm of 20,000 each.

The expendture should be net in the first instonce by advances for the purpose to the Dephtnent of hericulture. These advanoes Fould be adjusted at the end of the year and the final allocation of the liabilities made in accordance with the actual expenditure in curred.

There is provision in the P.M. S. Fstinates for an expenciture of $\$ 50,000$ and the Wohore Coverment have undertaken to make a conm txibution of 800,000 . What is asked of the Colony is that they chould be prepared to moke adrances to the Departent of Agriculture un to a

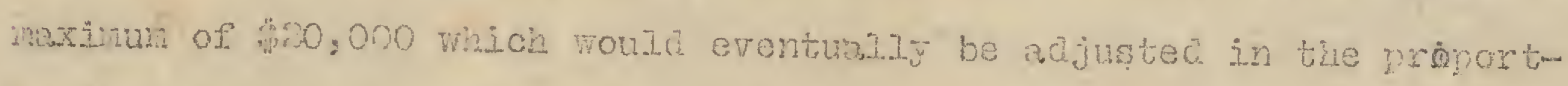
Lonte namer suggested above. An advence of $\$ 75,000$ womid be asked for in the exist instiance.

If this arrangenent is aproved (and I underetand from the Rosident lfalacca toat he regurs it as equitable) this deportment wizl accept injtial rewponsibility for aiz expenditure aneady incurred in Halocos in respect of the current year, and mind tale stope at the earijest possibie opportunity to tale over the locust destruction mork in miacca.

I hove thet the rork will not be subjected to the handicen of any hard and fast prohibition of the use of poison, it beine understood that this nethod vill not be used excent by truined wh enperienced men and under adequate supervision. The continued absolute prohibition of the use of poison in malacca termitory mould ade conm siderably to the difficulty and expense of dealing with this problem.

\section{(Sa). E.S.Hose.}

Ag: Director of Agricutture.

$29 t h$ January,

$301 / 31 \quad 1016$. 

Canchio

y296/1015

(G. 3.)

From Whom

Place

Date 8.99.

$20 \cdot 11 \cdot 15$.

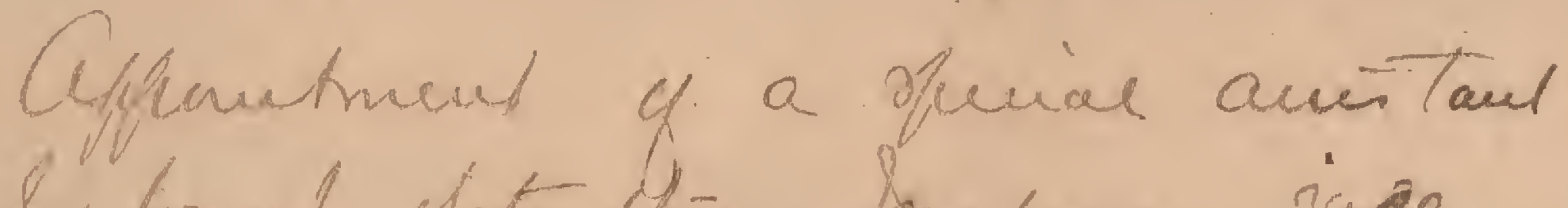

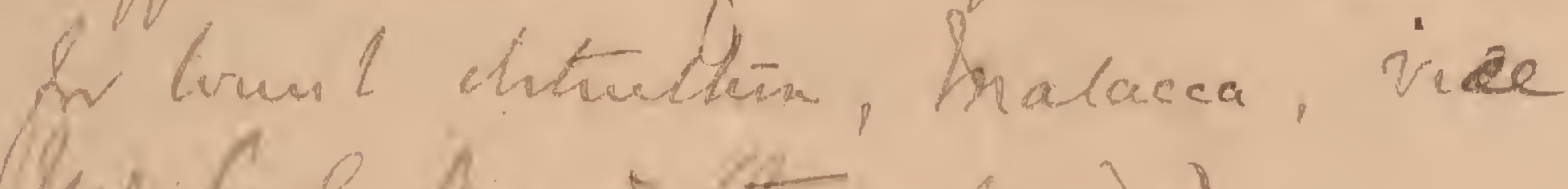

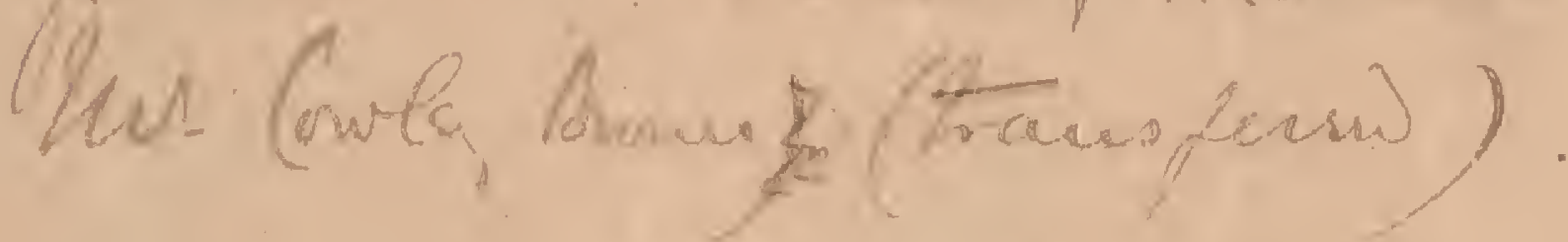

Former Papers. MINUTES,

Final Paper.

R. h.

Tor your Oboensachon

sid R. L.w. Jo."1

d

I hept this bow wethe ho Purkin came here.

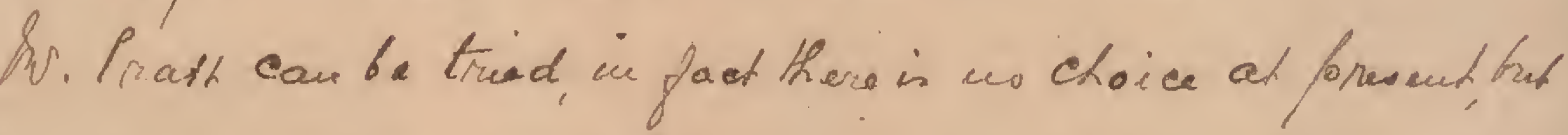
ih is a great draw baok that he theors no hralay. Shave told

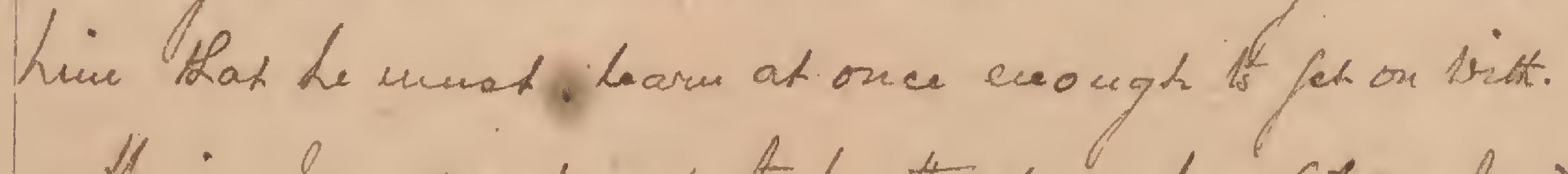

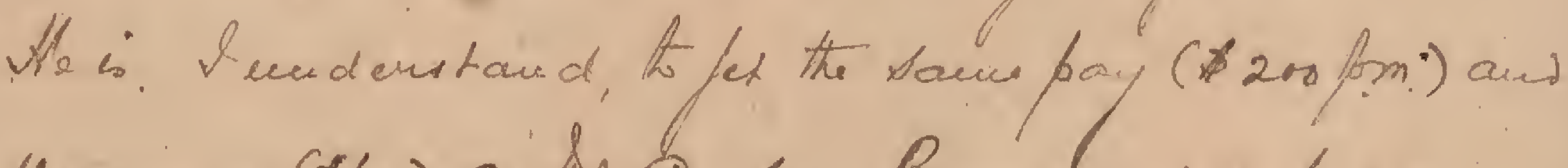
allowance (\$b-0) as Al. Burby- Pinow ond as he was Eugaged in Anigapose his expenses to Mala ce a Shoved he paid-No wavraut brie be required. He dos ust ricle a

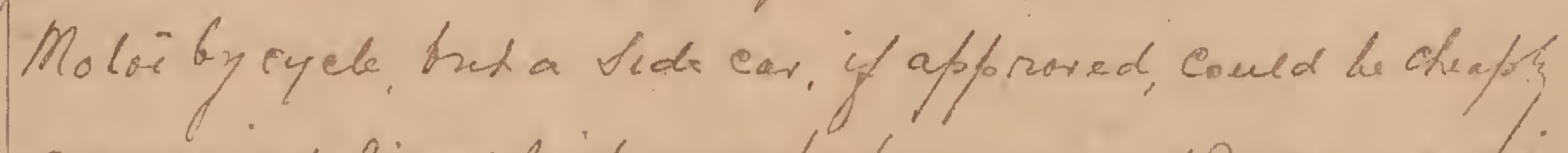

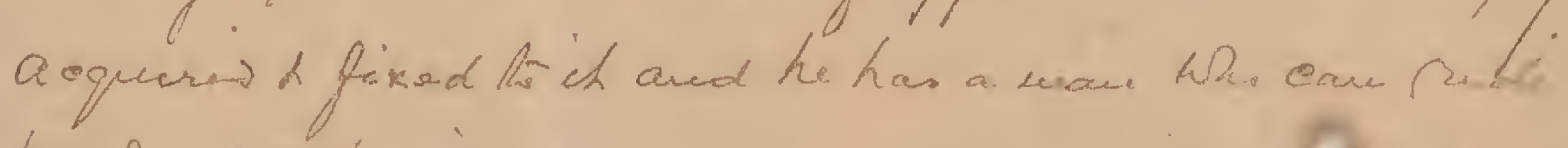
the holor bajere.

$B 8 \cdot 1 / 33$. 
of

appreved

$1 / d R \cdot P \cdot 2 \cdot 16 \cdot 12$

P. 8

troted

- thave Shanted Int Proatt in his wor:

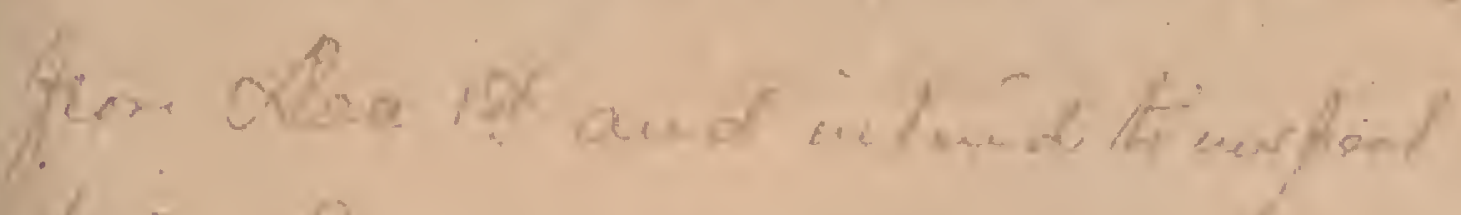

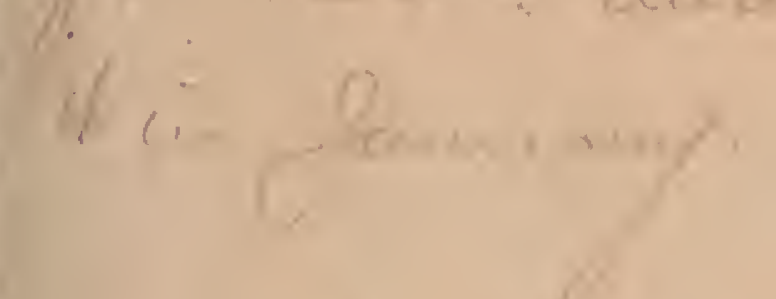

te in biative

Q.4 fardero

$\checkmark$ zinir Lins.

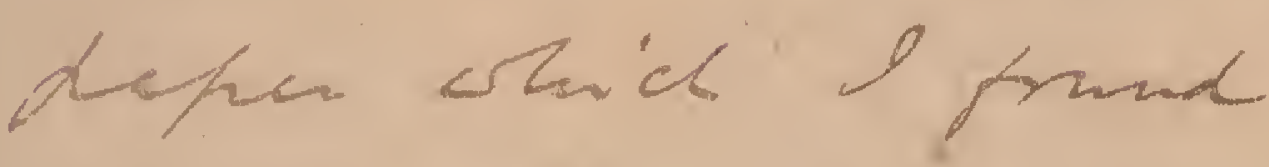

Q 2 tro

Len

DS. $12,15$. 
0

Minute paper No. Gaveriox $7296 /$ Qpes.

Sir

'O trave the thonow \& inform you

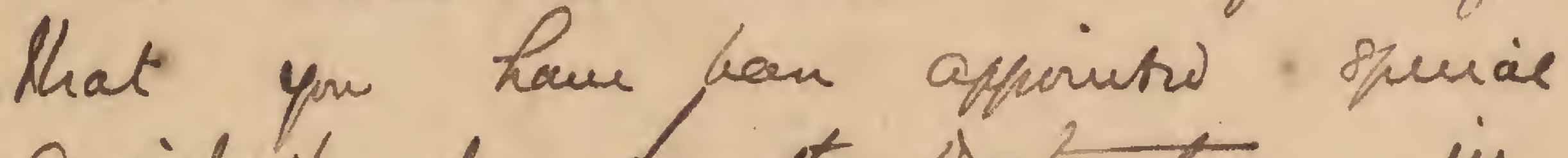

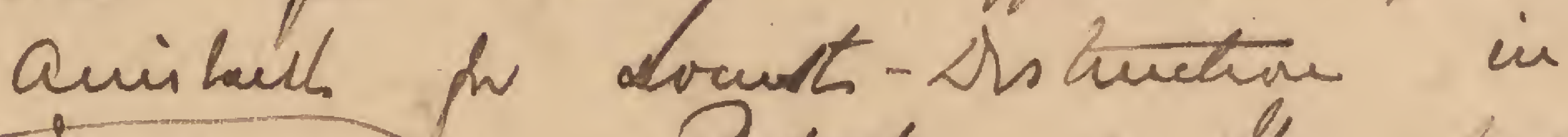
with sfeer Malacea?. Ritwitum is the sont

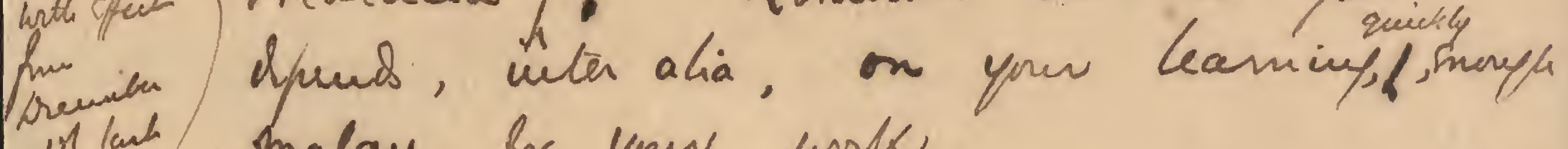
1. low sonalay for ypur work.

Your pras is

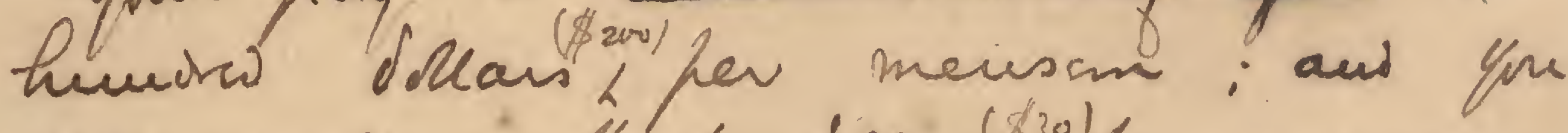

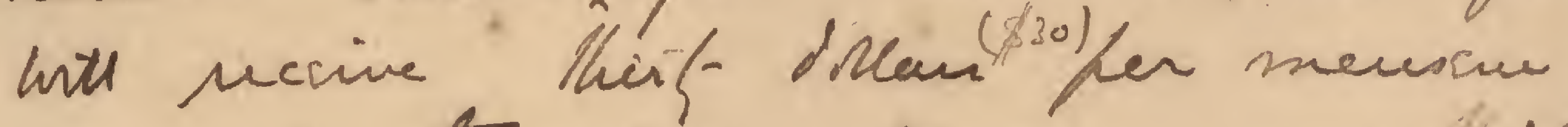
commos travelliup allowance; aced tisif

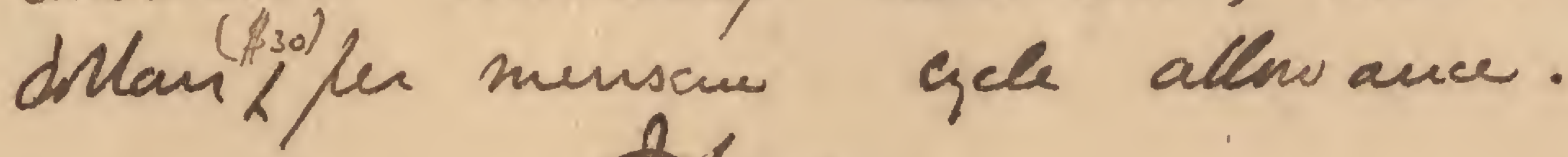

dham at

Ans

acowstract. 

\& arms wath the balf mast mantat cousts if the CS. 9 nith lease cases with infferstan alowe apar.

1 with Lean son it.

Cller for irsfuntan

yom zivecen (, bue sagas that b.cunchen Oaven witt if: Inote alom No late ufages baly I. I puevim C. the adraweer Llais oppum M. Fatt. Stan kat ar une unste o the sher 


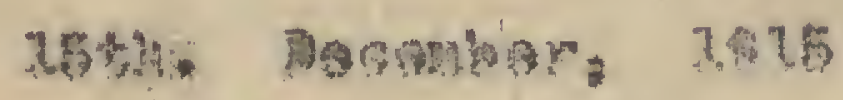

Dase Havers:

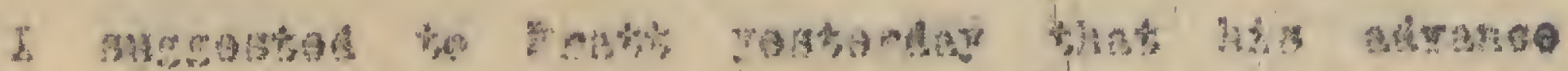

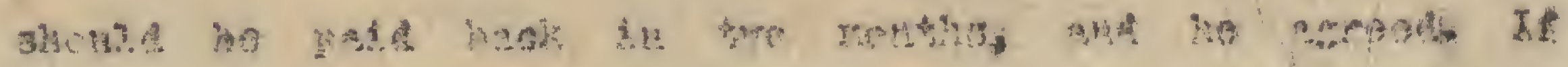

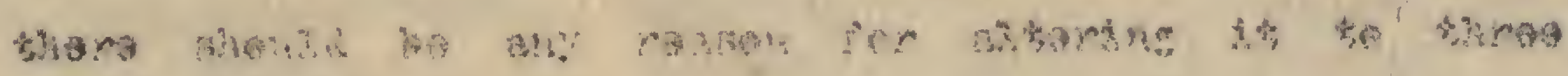

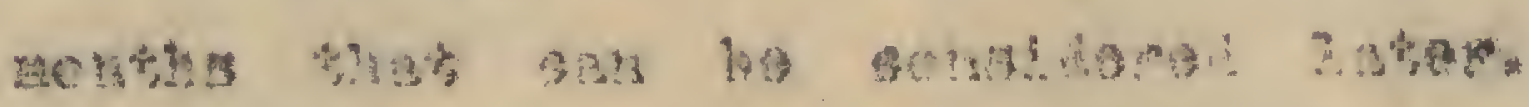

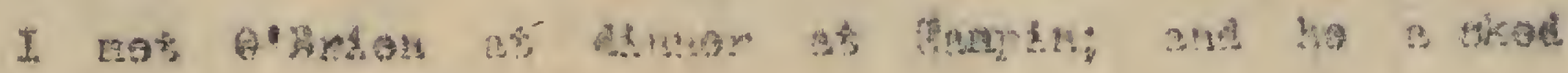

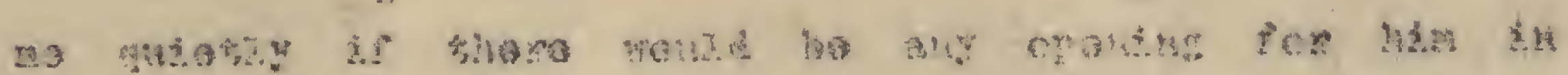

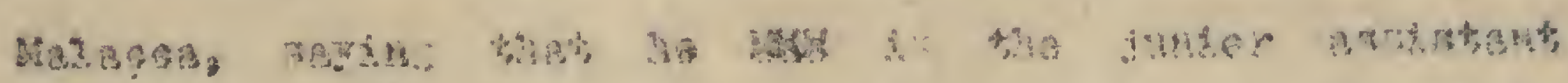

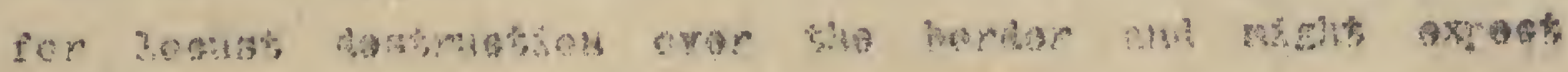

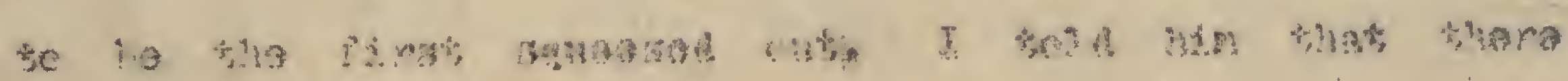

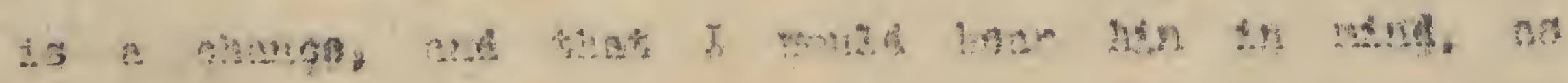

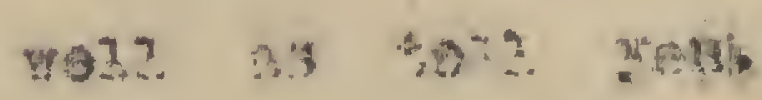

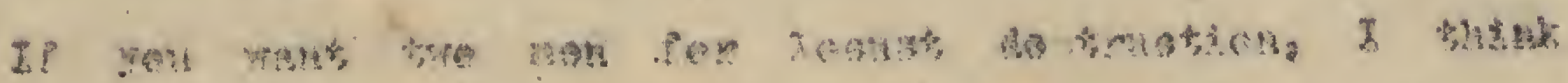

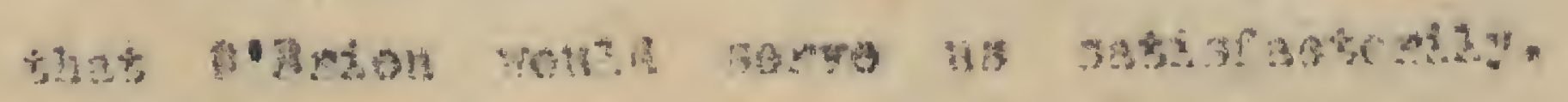

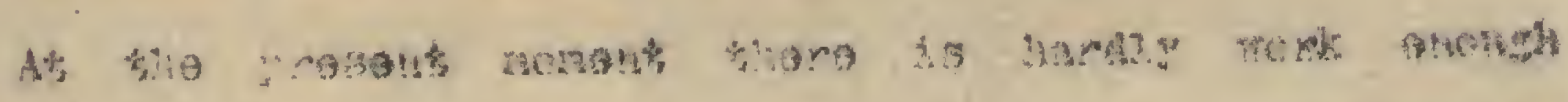

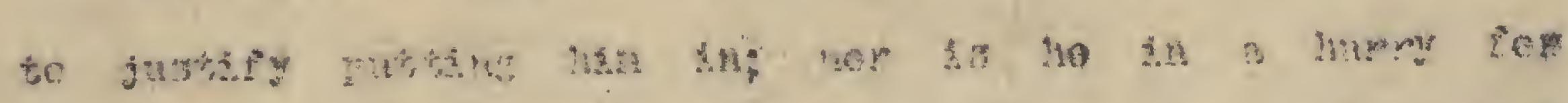

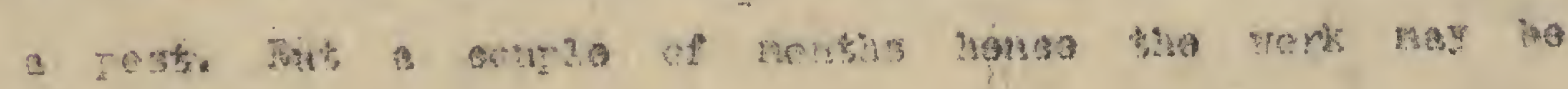
หองเ:

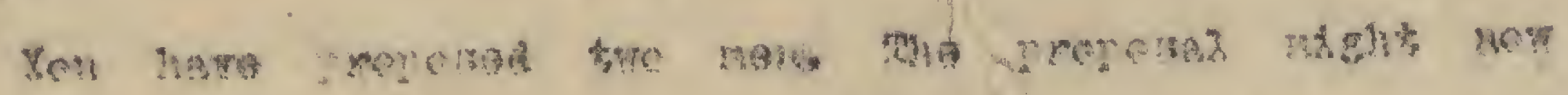

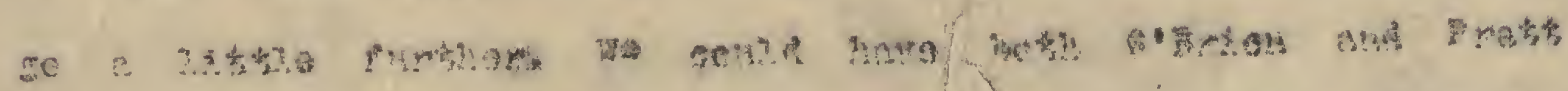

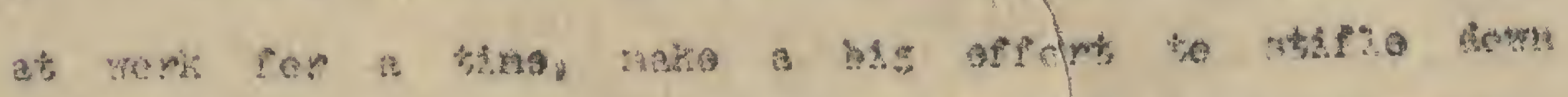

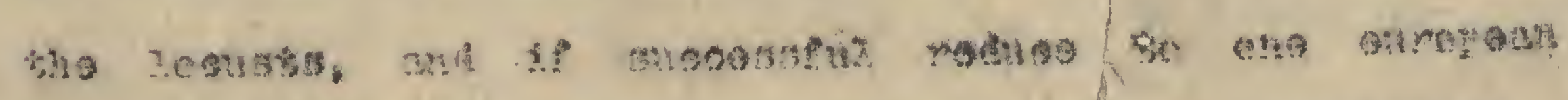

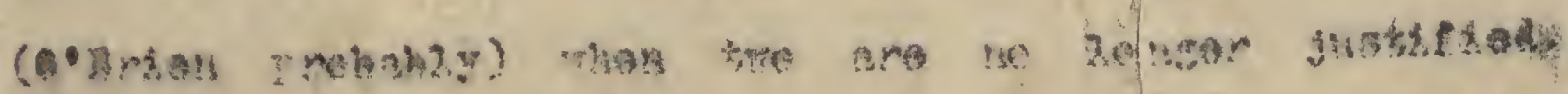

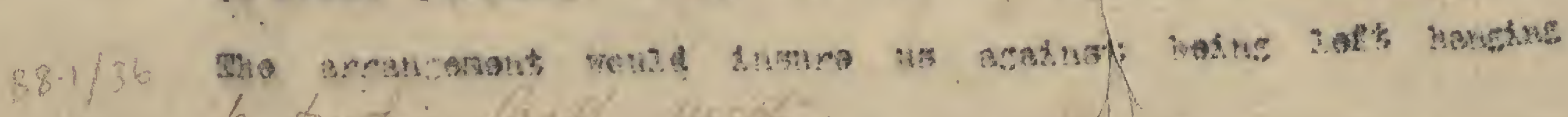




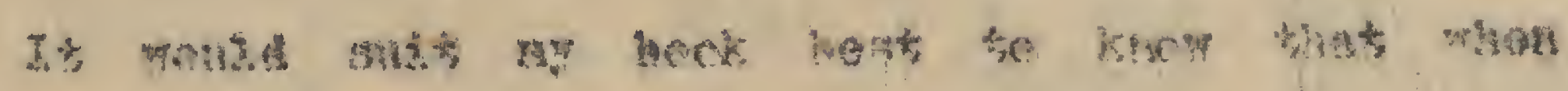

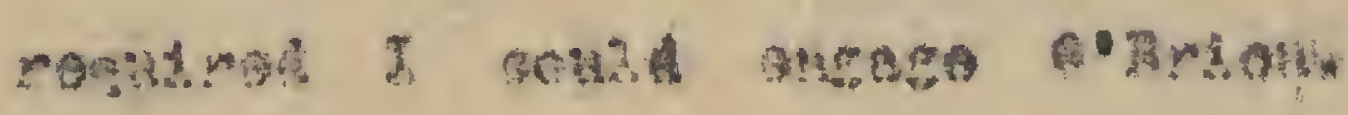

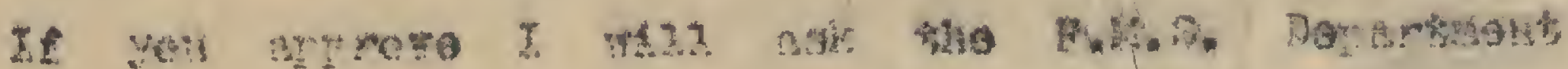

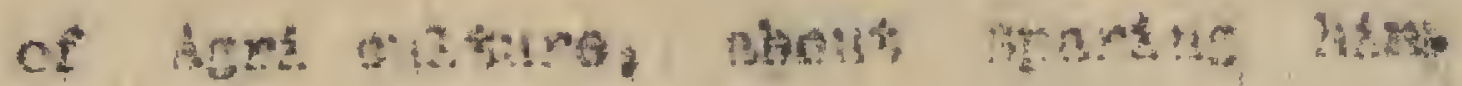

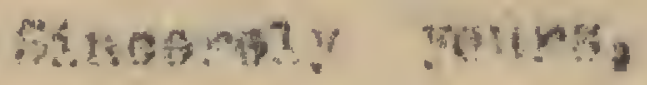




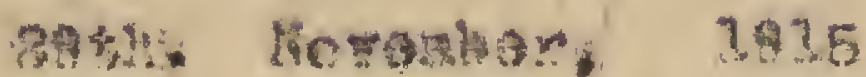

Danc Mre Iorists

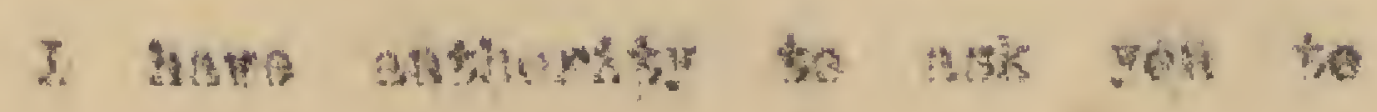

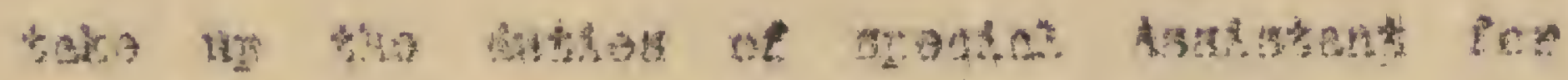

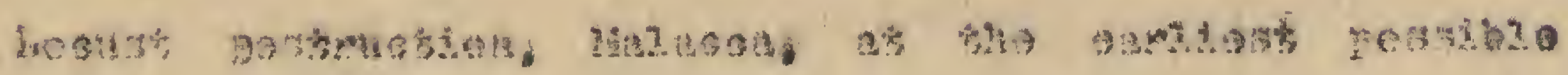

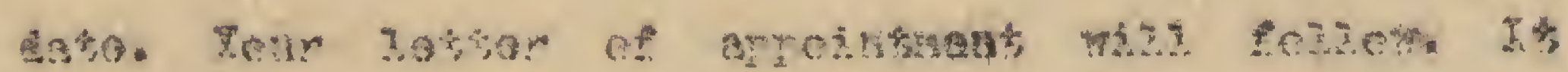

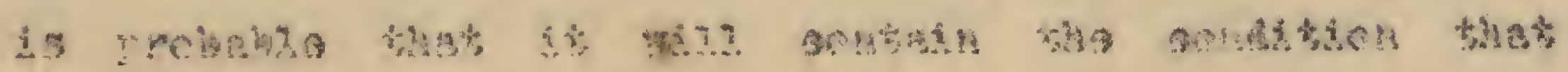

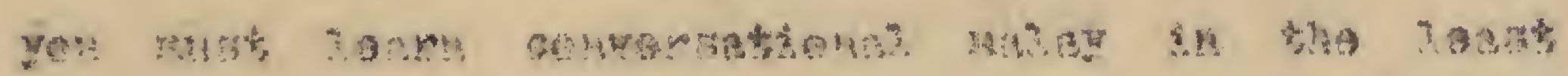

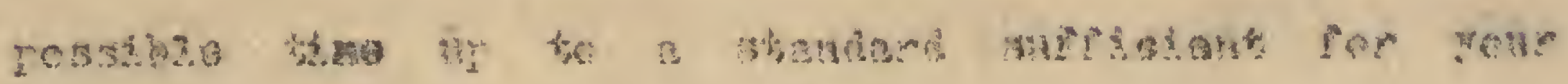
werk.

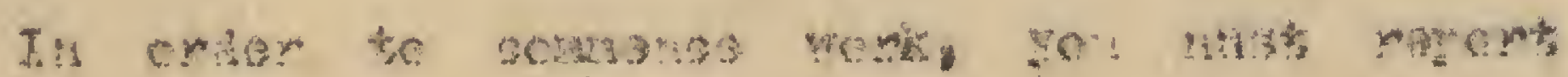

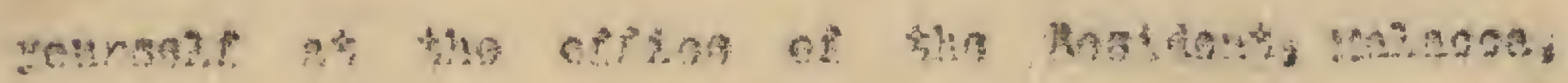

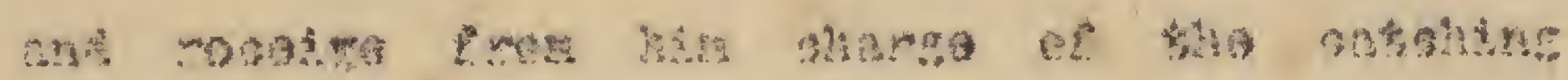

arparatus ats.

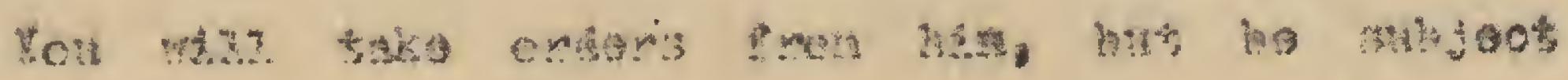

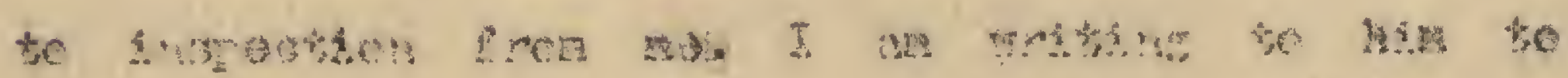

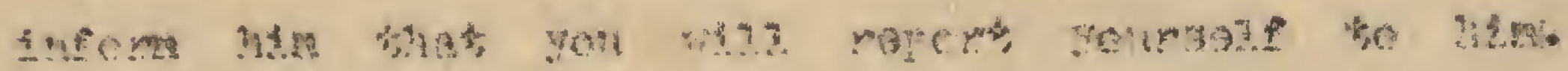

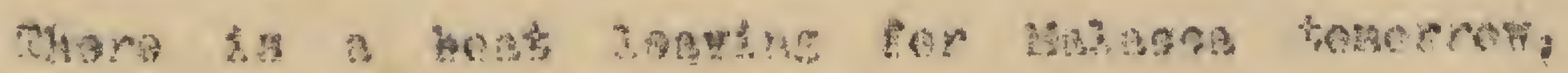

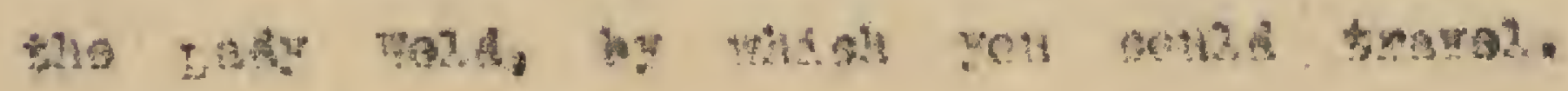

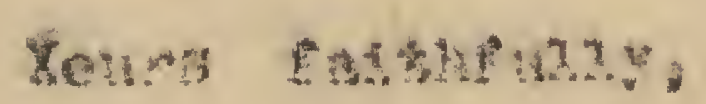

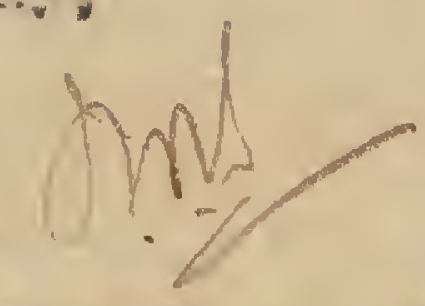

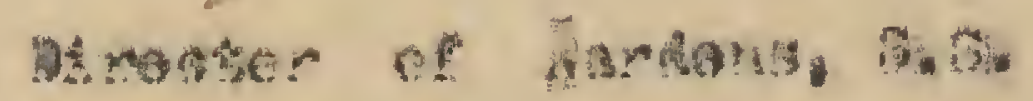

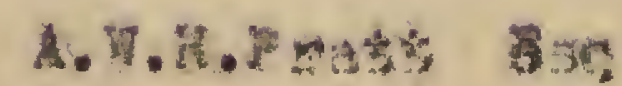




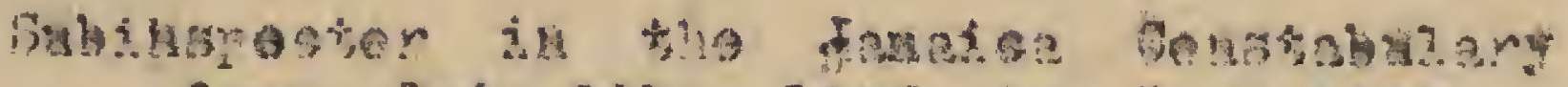
fres Bet. 84h, 1293 to Bas. Ifag

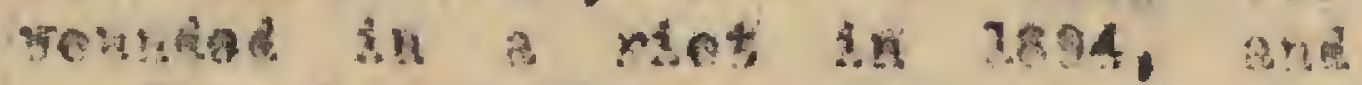

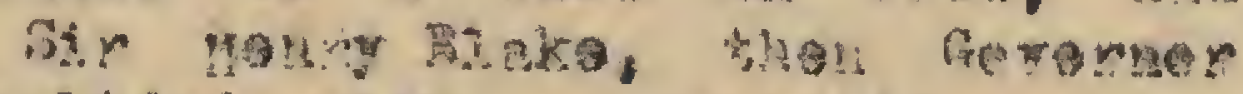

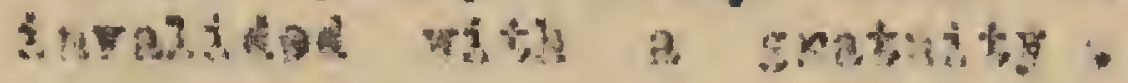

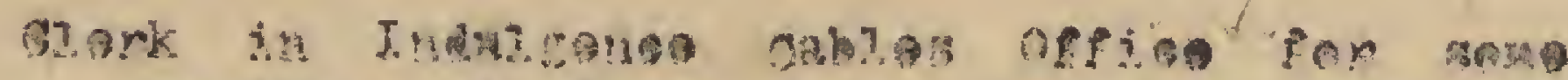

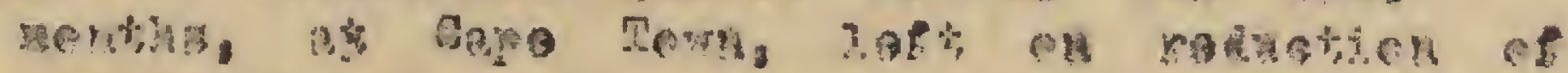

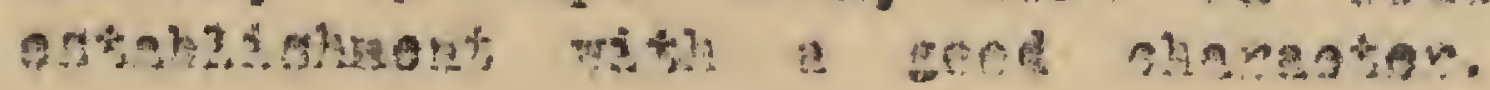

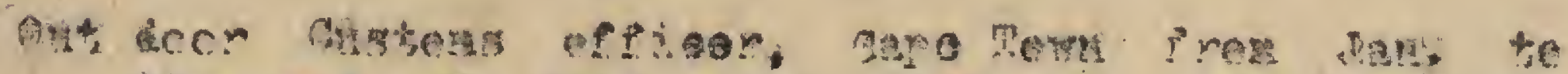

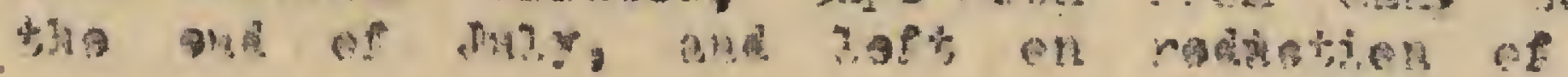

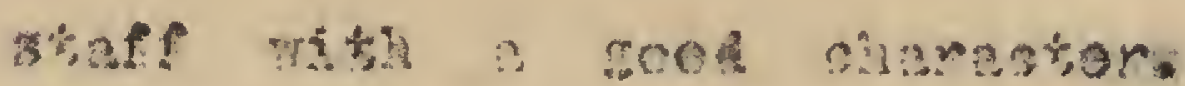

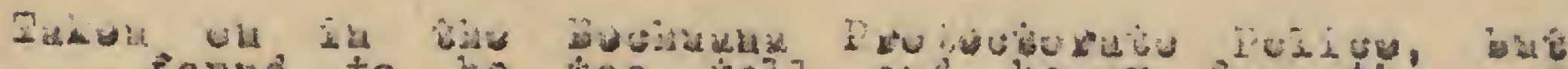

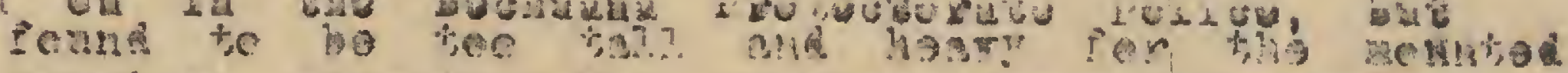

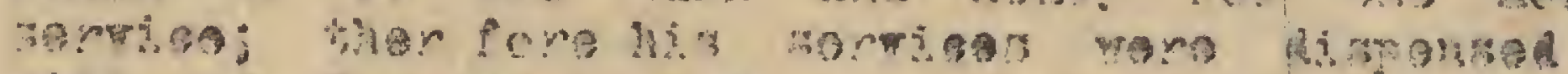

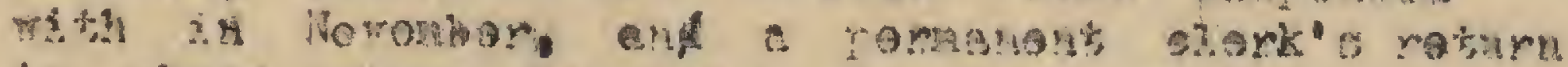

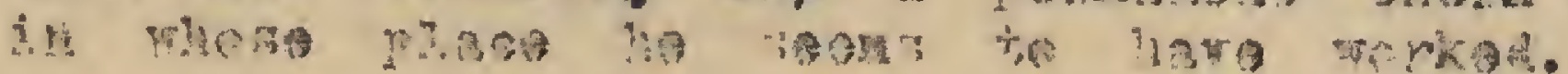

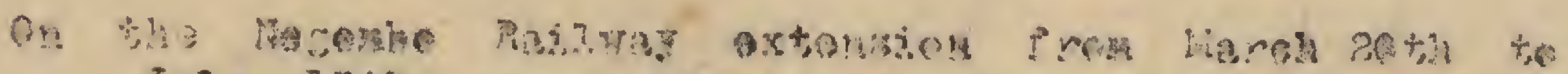

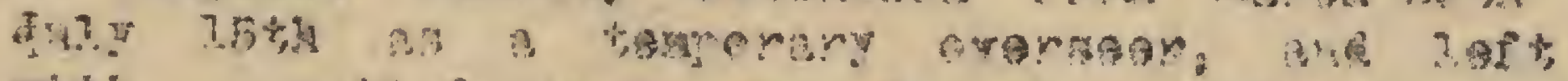

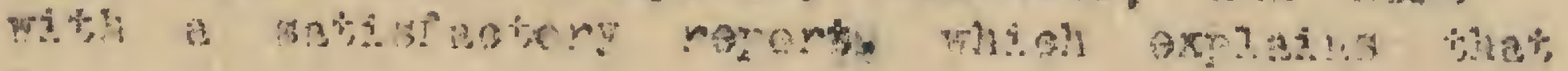

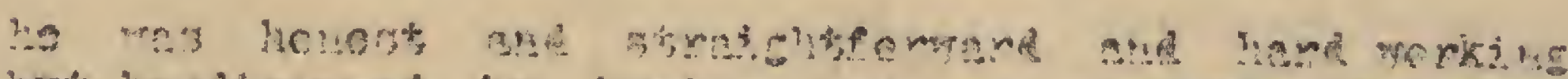

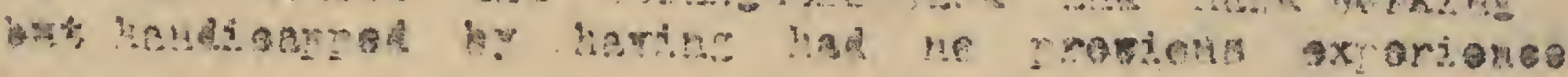

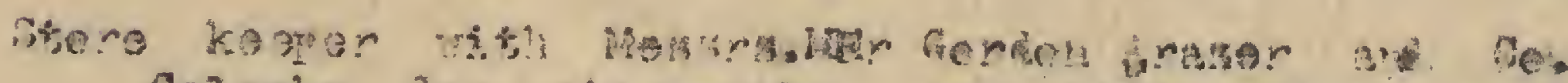

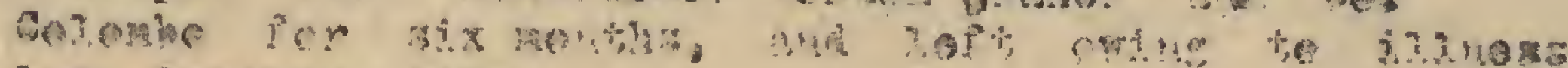

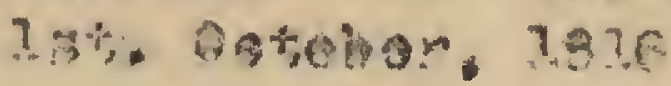

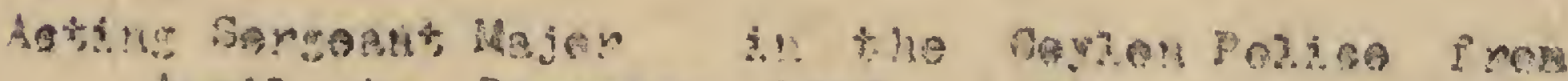

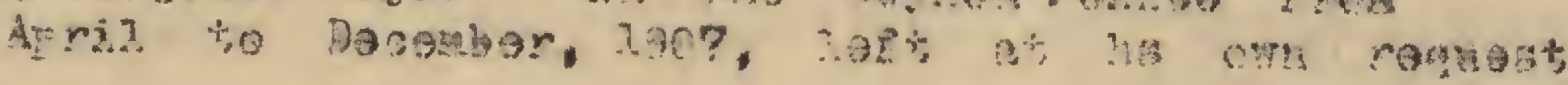

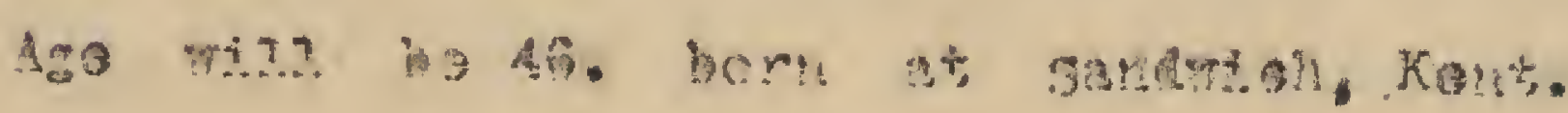




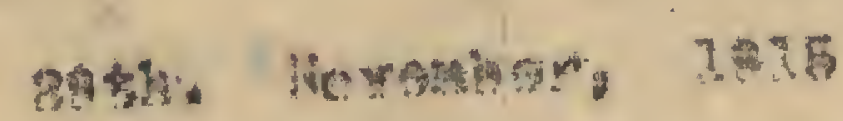

A ${ }^{2}$ s?

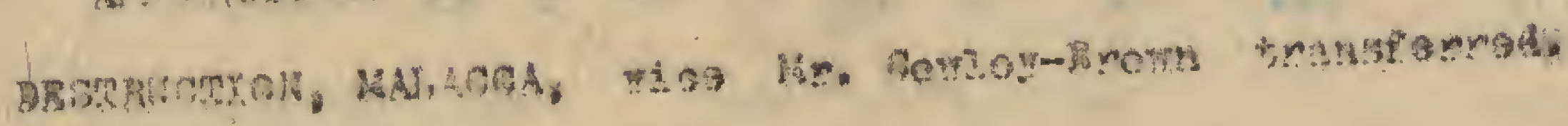

ssp

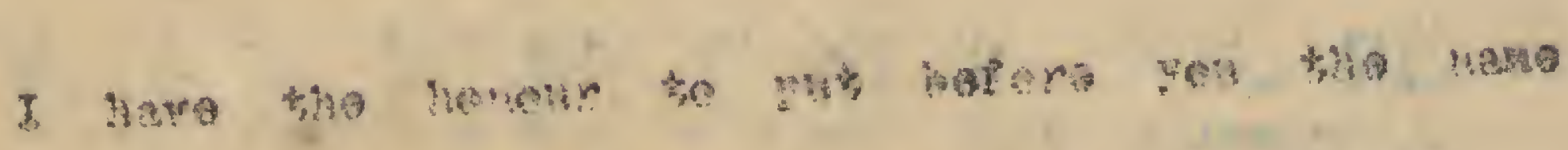

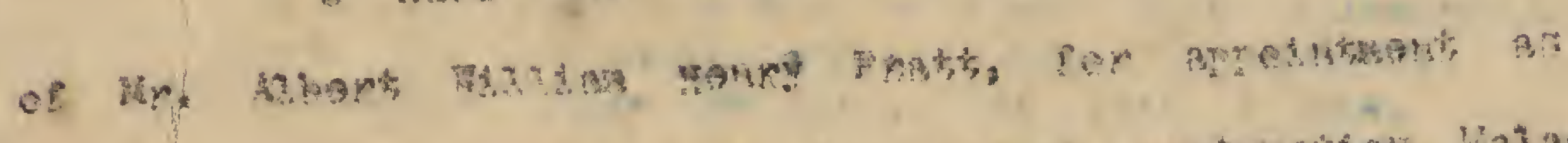

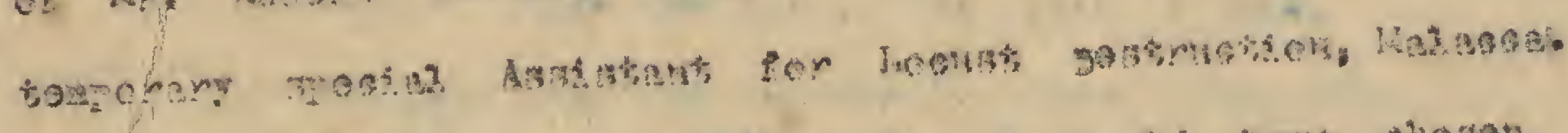

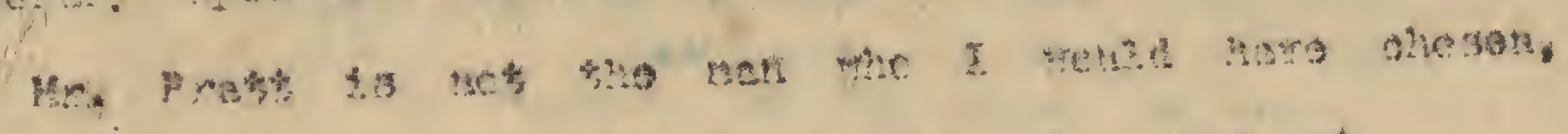

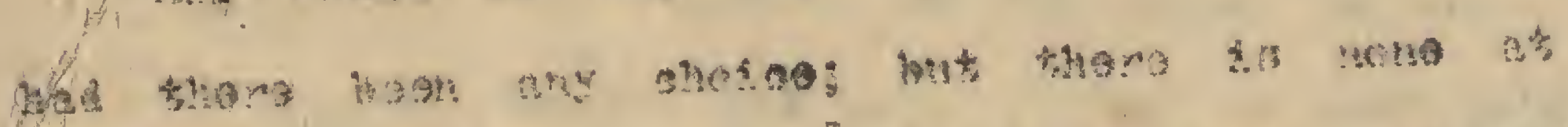

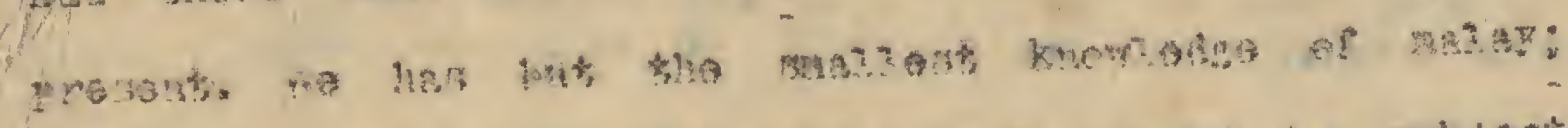

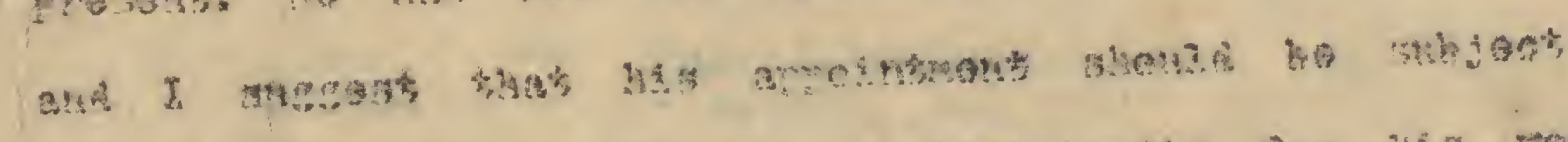

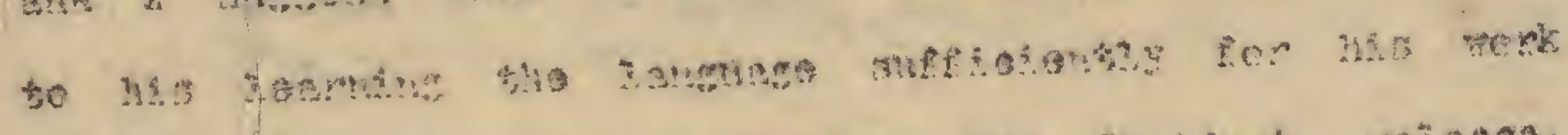

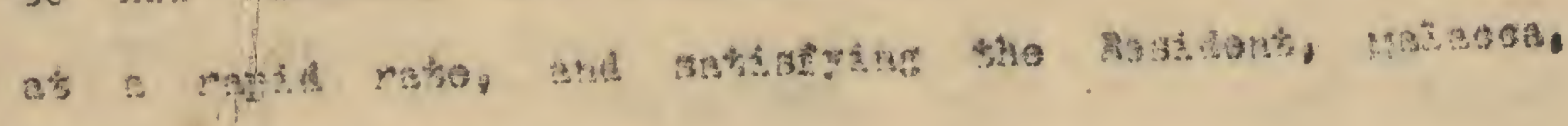

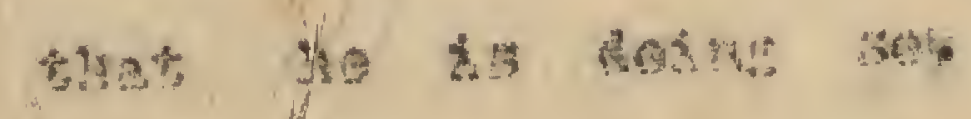

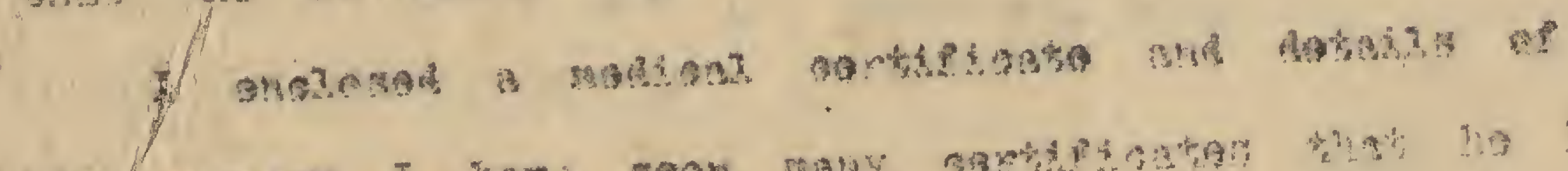

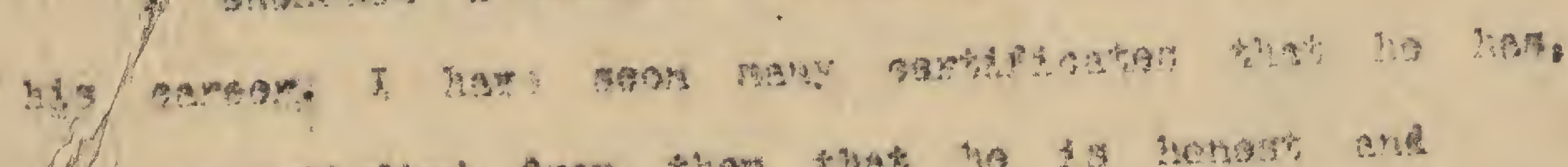

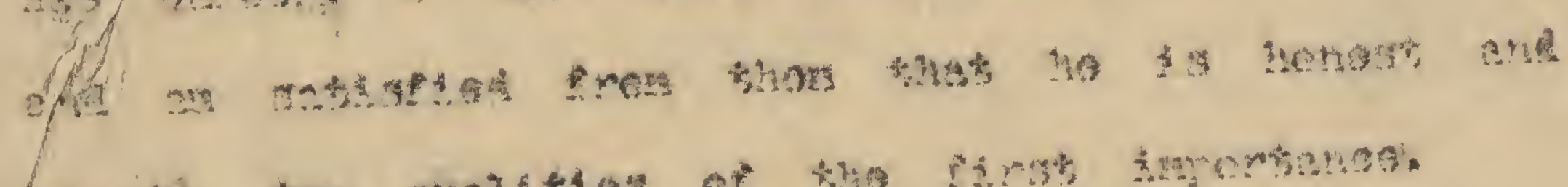

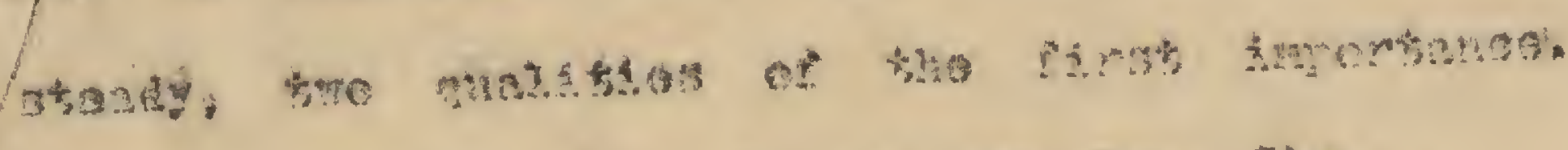

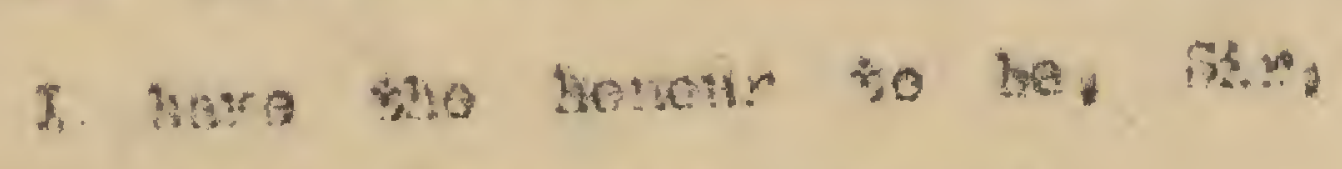

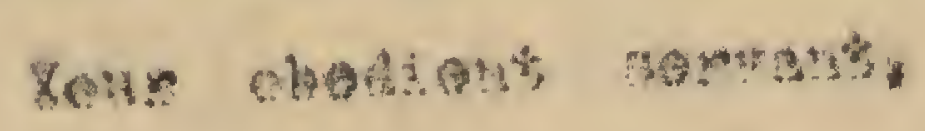

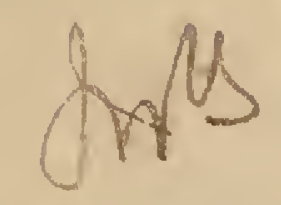

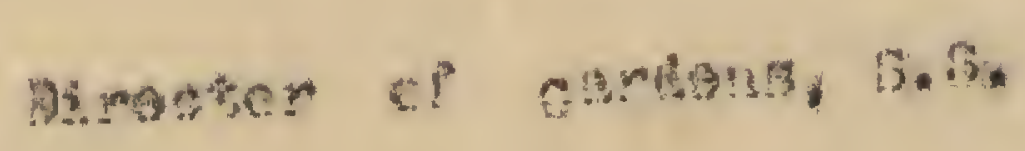

The Hetermiso

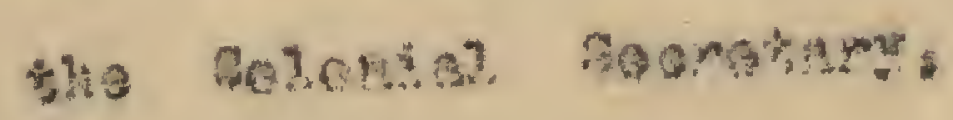


Lwiheratt

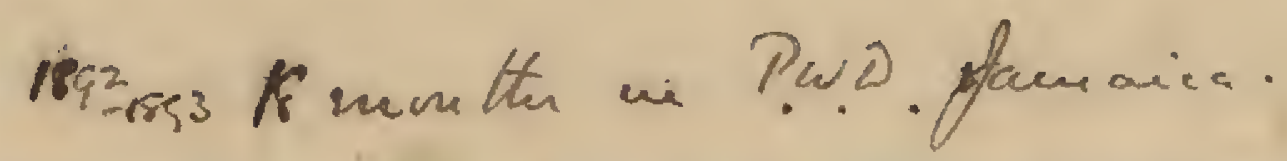

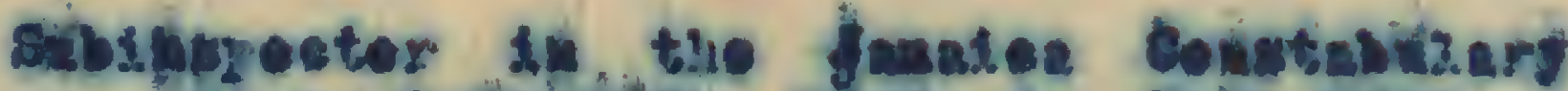

1893

$-1899$

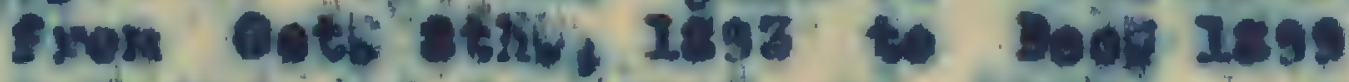

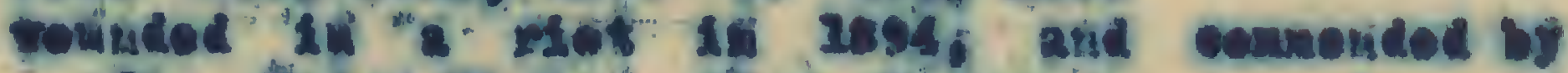

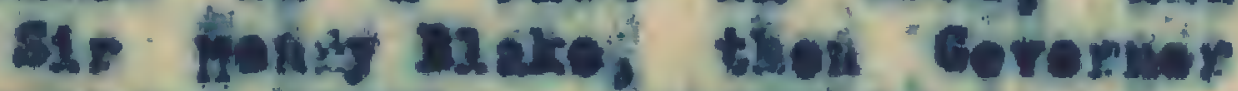

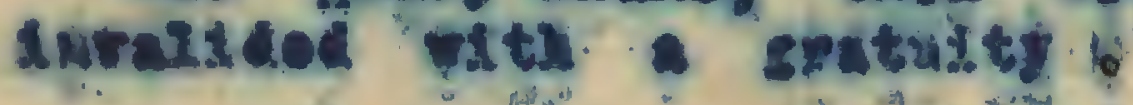

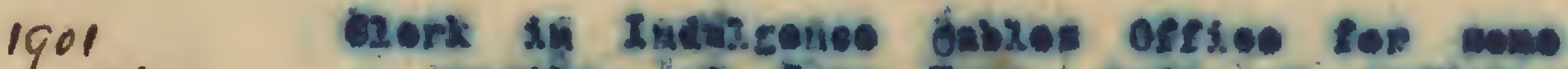

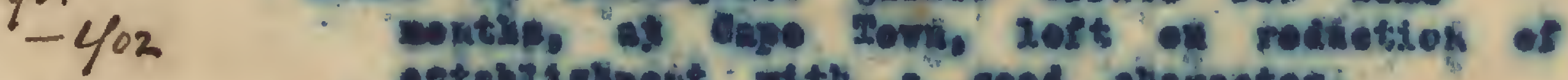

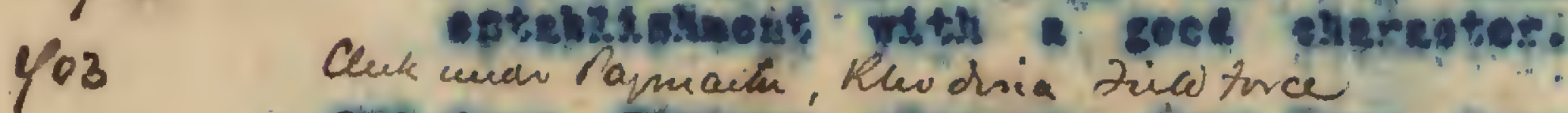

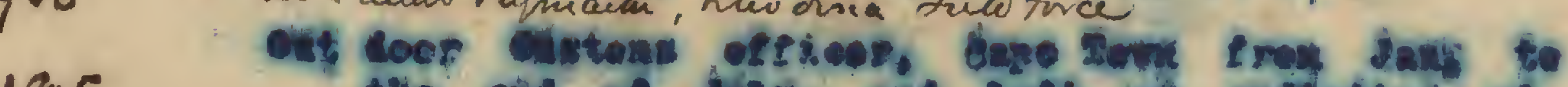

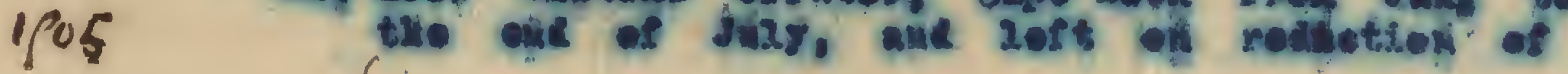
ataft uts a geod eliaractory

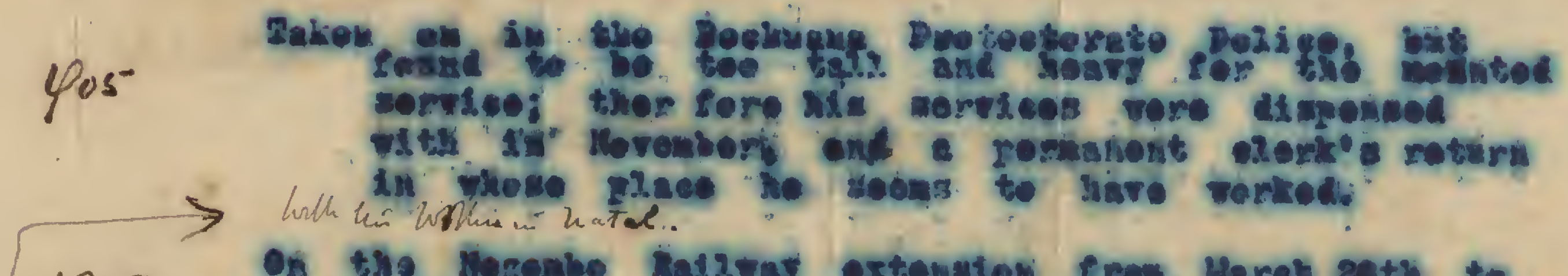

1908

$-1910$

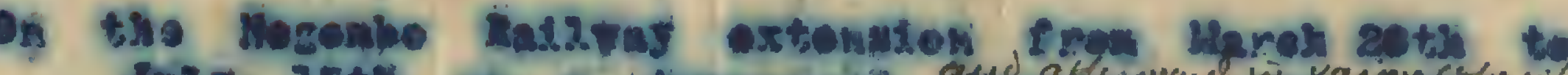

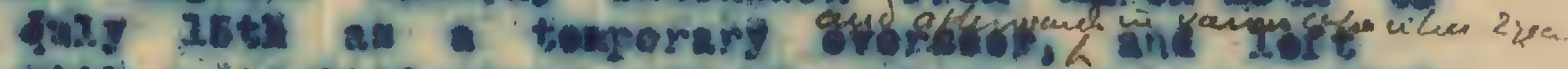

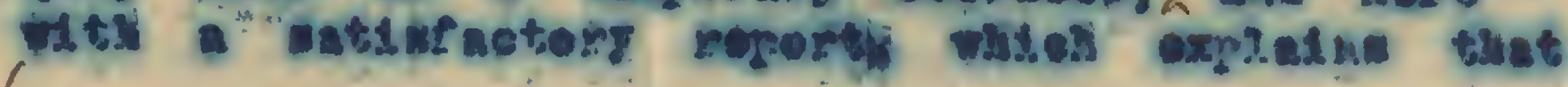

so ges henent and etraightiforvert and herd sorkine

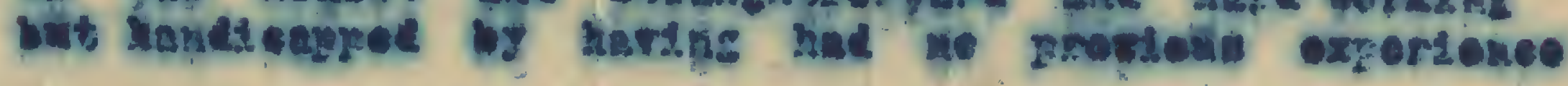

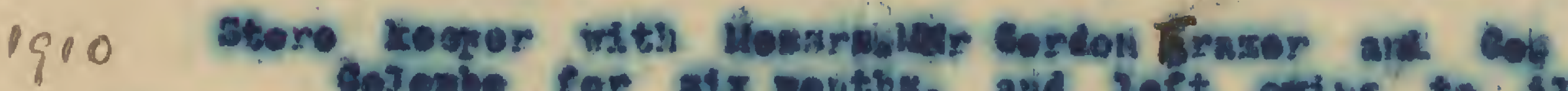

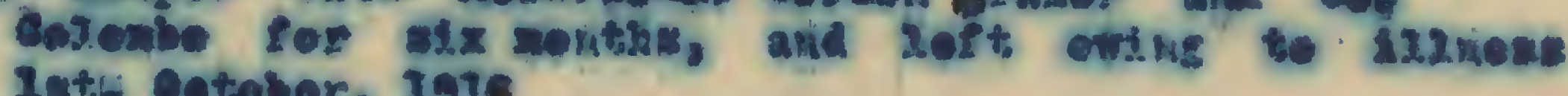
Ists Oatolor, 1910

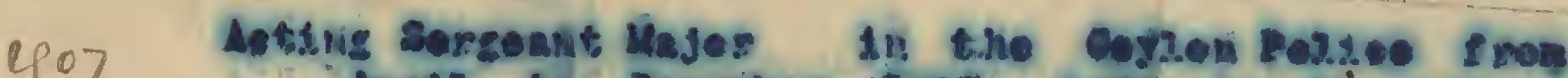

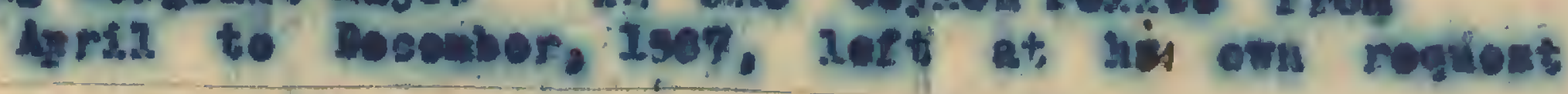

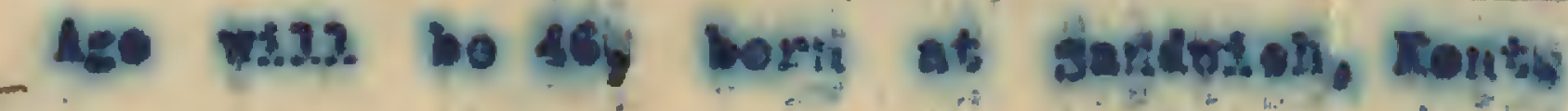

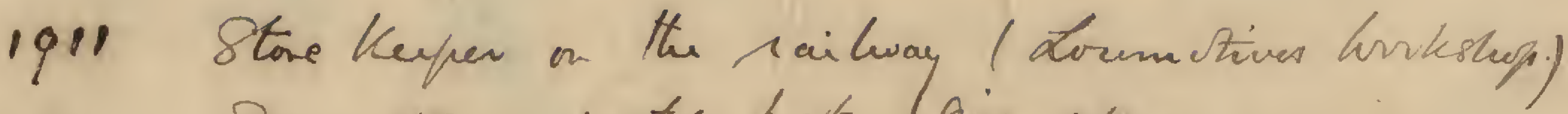
sumith - muter fort frien ofs -

Qrif. on a rubber cstate.

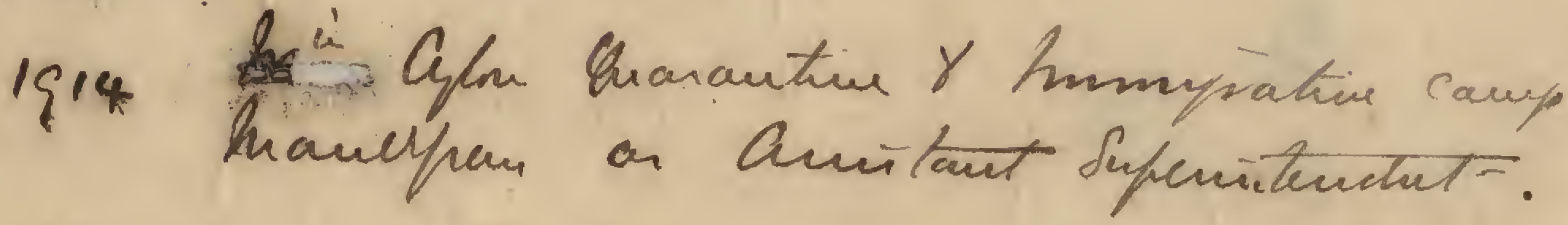
1915 


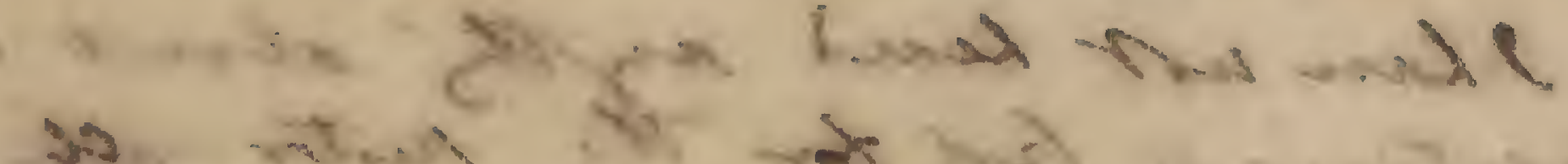

(a) 2u. Mh: ME: MEMORANDUM.

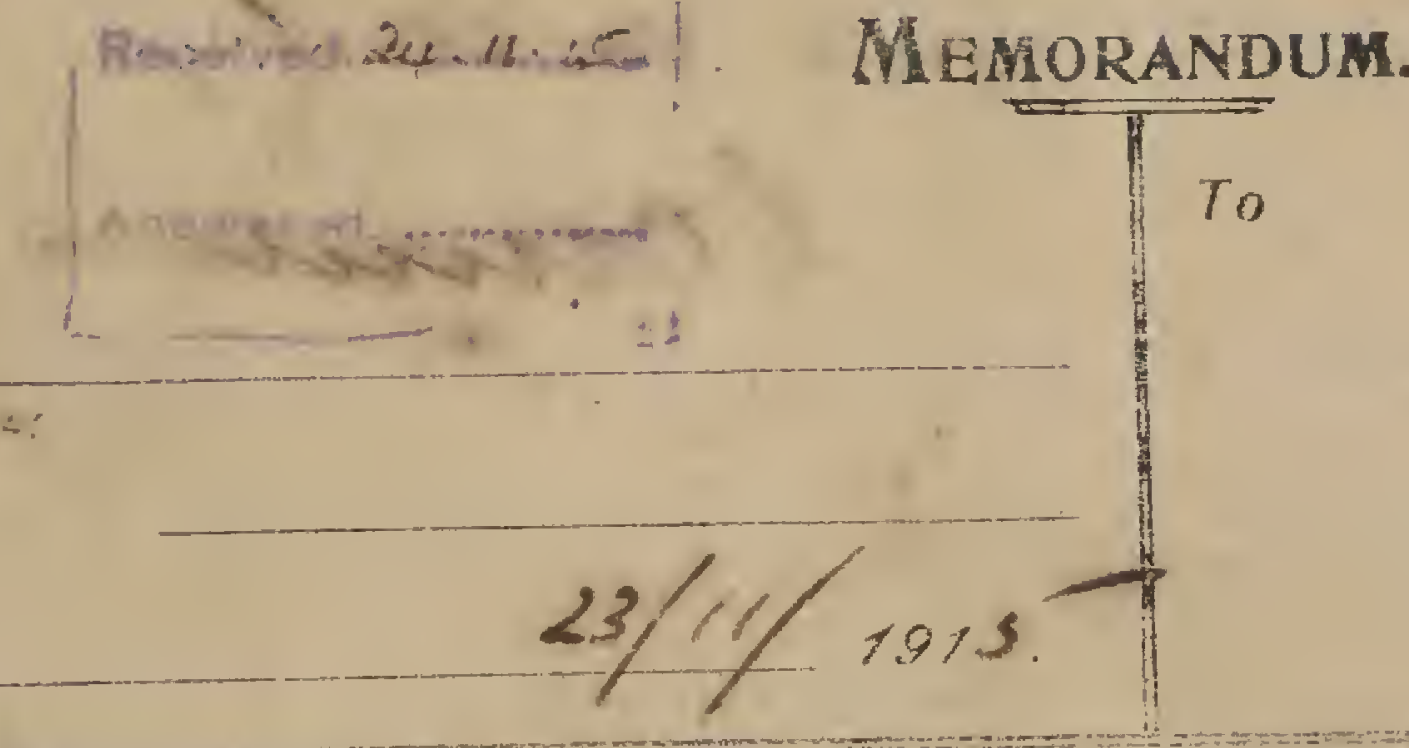

Len Ampirs,

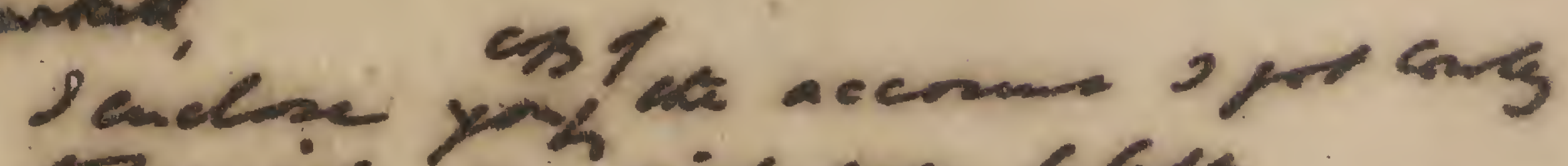

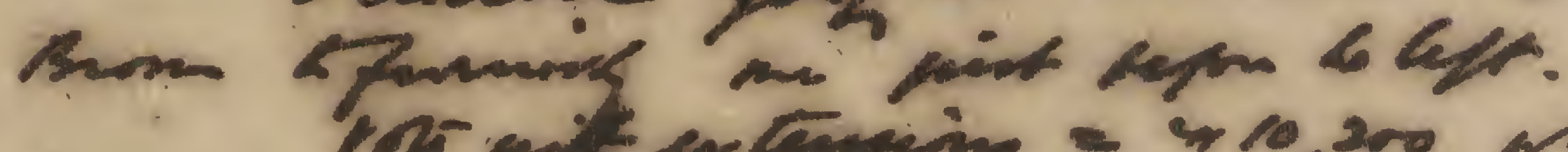

te appenxmiate allspent.

I am aprid it will he domerntat

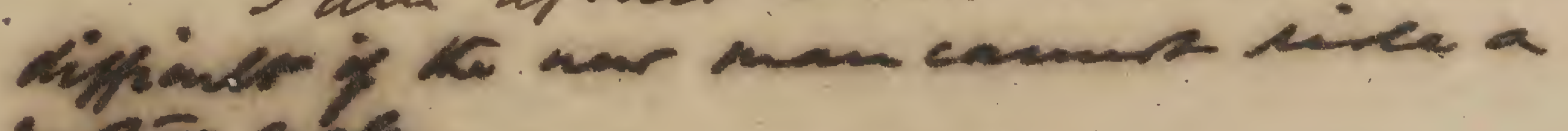
miñ a $\mathrm{cec}$.

A. man or keshipi ins mas, shual he

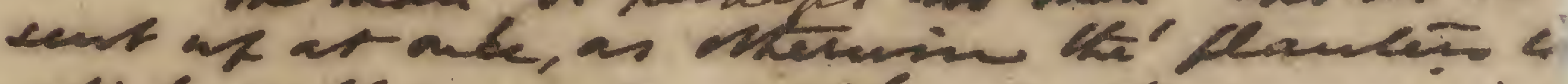

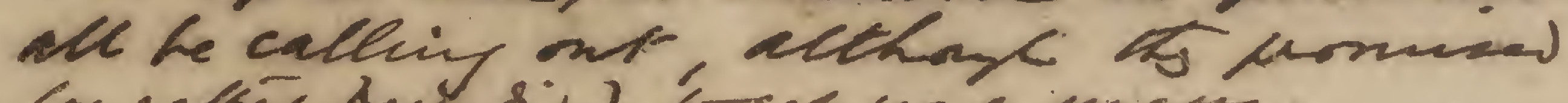

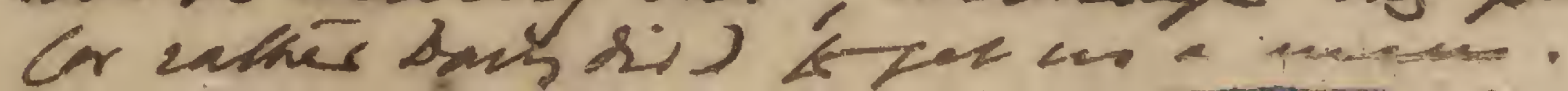


Copy.

R. M.,

The rote and present extensions are

$\$ 10,200-00$

The expenditure as at 31st October was $\ldots$ - 7,816-80

The cash in han as at Ist Notember was ... \$2,38.3-20

There are 8 scouts at $14 /-$ per

month i.e. Scouts, Norember and

Decamber salaries $\quad \ldots \quad \ldots \quad \$ 224-00$

Two scouts receive an allow-

ance of $5 /-$ each $p_{\text {. }}$ m. i. i. $_{\text {. }}$

Scouts Notember and December

Allowances $\quad \ldots . . . \quad \ldots \quad \ldots \quad$... $20-00$

Inspector's salary and allowance

for 9 days $\quad \ldots . \ldots . . . . . . \quad 78-00$

The new Inspector salary and allow-

ance for Not. and Dec. may be taken

as Nor. \$160, Dec.\$260 ... ... 420-00

The Locust coolies daily pay for

9 days may be taken as 576 conlies

at 40 cents $\quad \ldots . . . \quad \ldots \quad \ldots \quad 230-00$

$5972-40$

From 10th Norember to 3lst December 19.15

for Locust Coolies Daily pay, Trensport

Expenses, repairing trap-bags etc the

amount of cash in hand is roughty ..... \$1, 410-80

I make no allowance for new trap-bacs.

Sd. P, C. C, $-B_{\text {. , }}$

$9-1 I-I 5$. 
No Minutes should be written on this page. A separate half=sheet to be used if required. 
n. Slates

$$
10 \frac{7}{14}
$$

(G. 3.)

From Whom

Place

Date
$(2 \sin 126.0), 3)$
K. Lempur

5.1 .14$.

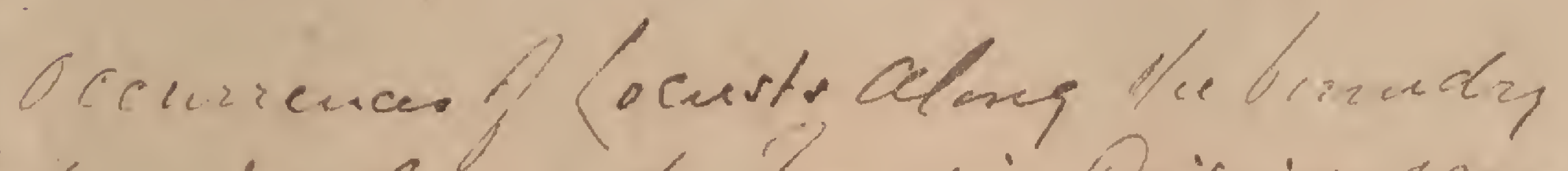

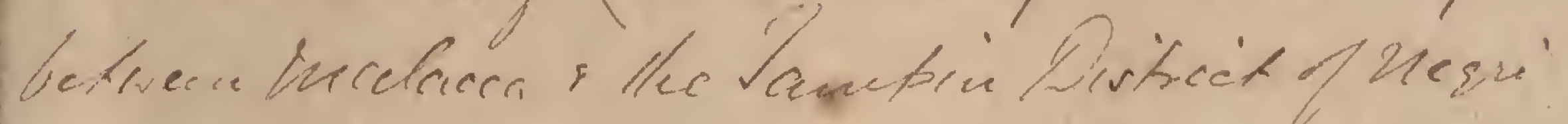

Sembilan

Engine stretlear stepsovied be tratienty

the Cot Gort to Co.ofercte in the Coupaign

apainst the

Former Papers.

MINUTES

Final Paper.

cS

Pin

Zueyounobserectimi.

$$
\text { 9.1. "R.9!. }
$$

cs

Actin in Unalacea sto go hand in liand with cretuin in llue adjoing bast of le. Serer bilen.

on p. of 7 the ogl: Bulitiur Fus.

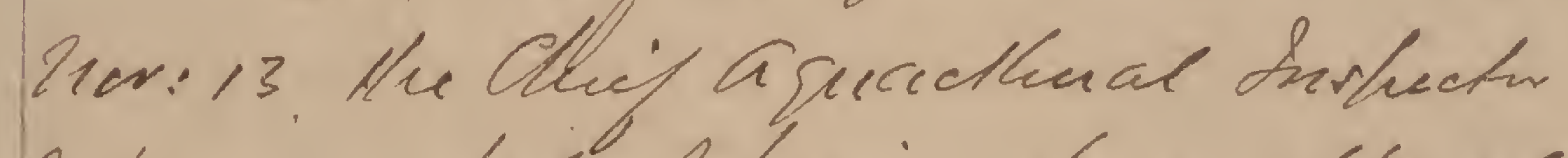
sxpeures a hofe of having shave apporabe

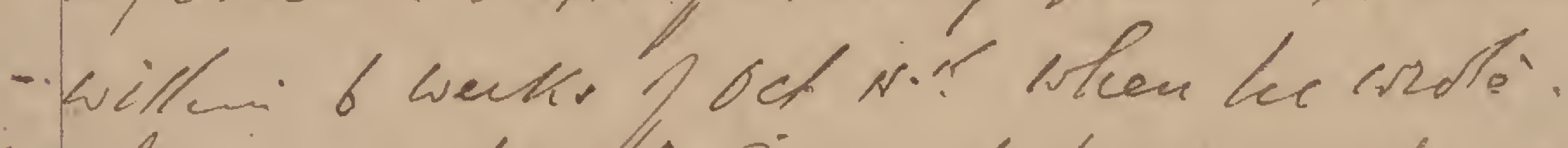
I. suggest that the Bues Lit be asker 1 they coun

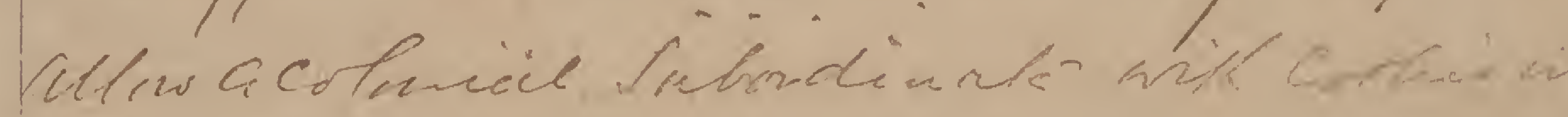
Saflyount an. 


\section{Sheet 2*:}

cis

Liavicantlene int N:2.14 住位.

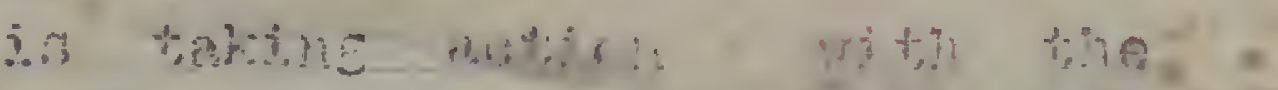

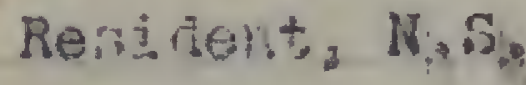

\section{E.R.M. 5.6 .36}

R.M. For report,

\section{R.d. W. $5.6 \%, 74$}

C.s.

17.2.

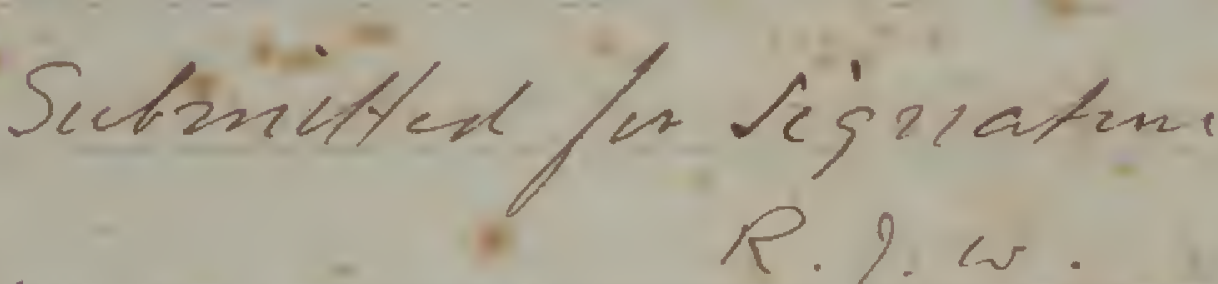
Q.?. 8. $7 e t, 4$

Yecasenes

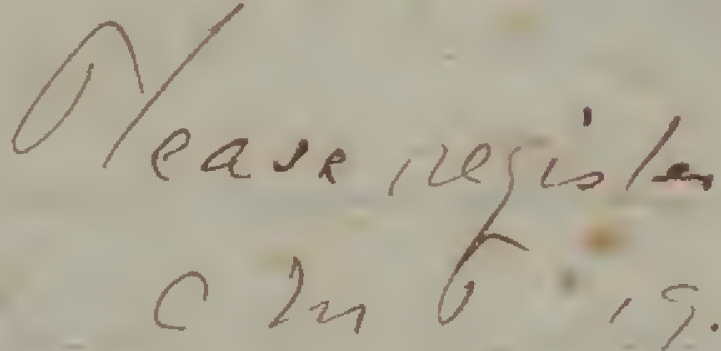

As roon an the rote of b5co or war anthom ised J. commuicated with the Aas, Aericu?turen InTectorin W, s, and interviewer hin on 24.2.

- arraned aptor aiscrising tho . $C S$ Ceferteres, Seit
he ruedith oftic

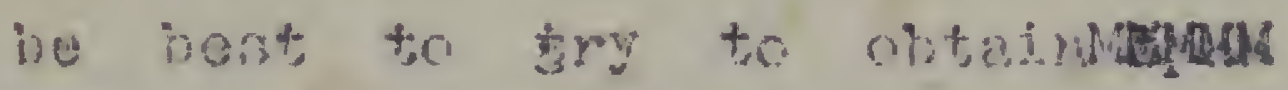
loan of the servicen of three F.Mn. natag nendom with knowedese

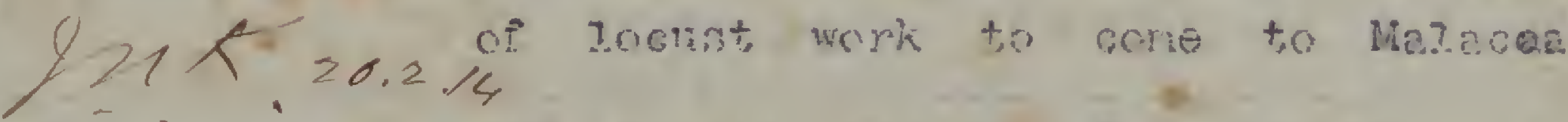

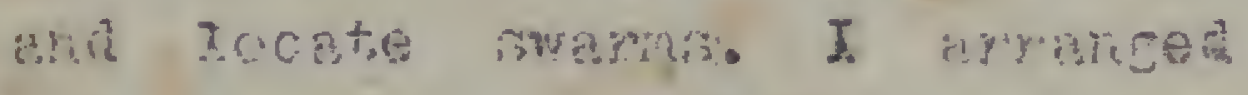
C $S$ thet he nitit to the Doof A.

\section{Worrauth ruainew}

Resident, Maracca,

D of G. To See

E.R.M.

23. 1,14

C.S. Seen

L, C, D, 而, $25,8,14$

C,S, seen

\section{I. $\mathrm{H}_{0} \mathrm{~B}_{1,}, 13.5,2 \mathrm{~K}$}

(5) Letior frot U.5. asater $38,5,34$ C.ธ.

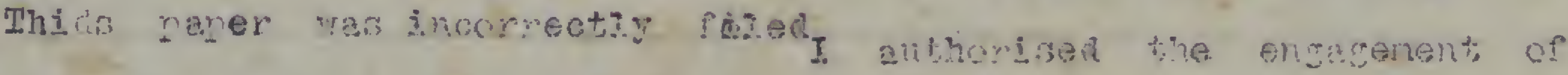

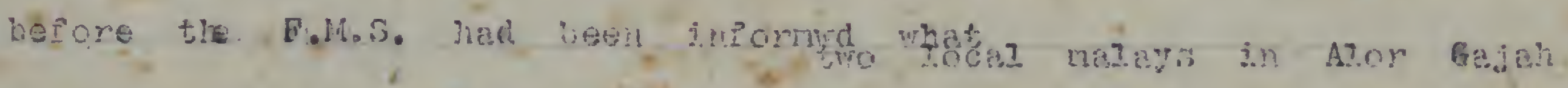

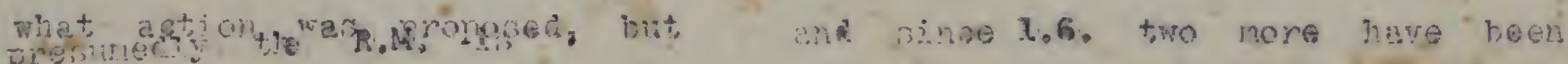
pro.1/45

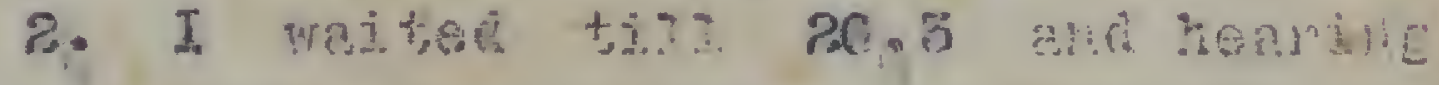

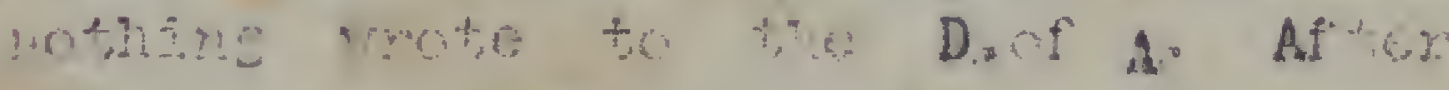

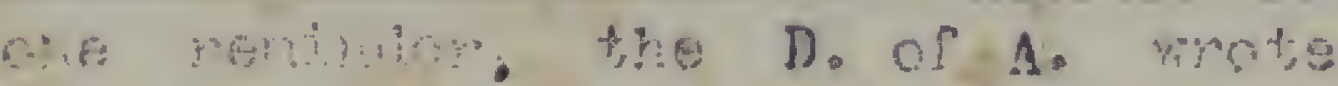
on 84.4. that, the randomis colld not he ingred.

3. We have he arocial hemartabt sere and lat no plethore of offucen to ayt th work of this

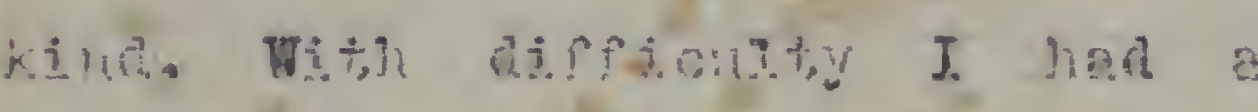
trap made Ais roon an J. found

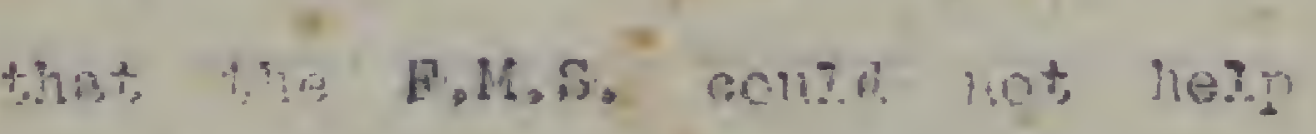




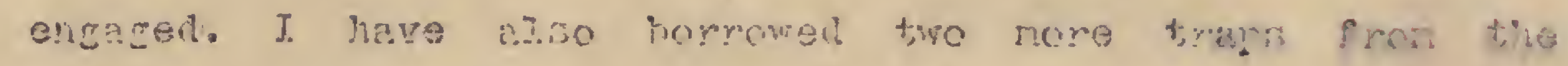

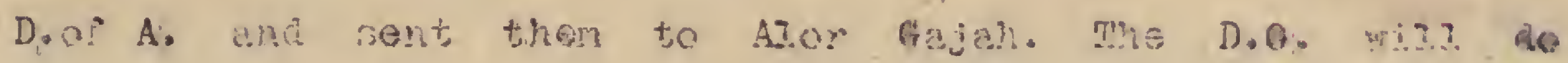
what he can, bit he han an ready nome work than he can nange.

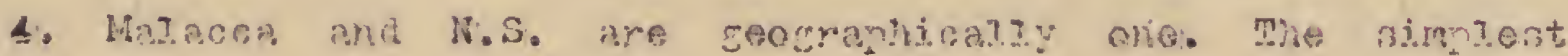
and nont efrective man th for the colory to ask the ros. losurt steif to deal with hatacen end pey for the work

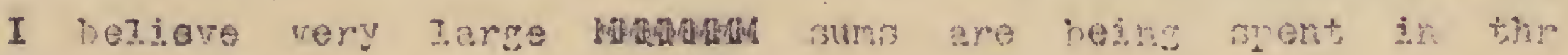
F.M.S, I have ano creat doubt as to whether the loousts

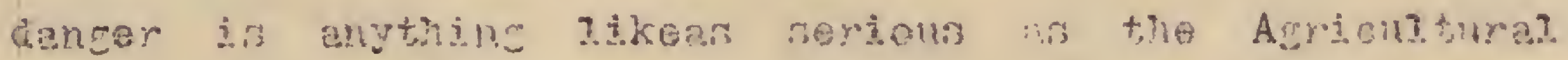

Depart,nent, F.li.s, renpeisent,

5. The artemntive in to detain an officer from the Gerlens' Dopartinent, to cone to Monacce, orcanise a staff, and of comrse wrond a cood hea? of nomev.

6. The D.0.A.t, te?3n me that so par the rom?e have

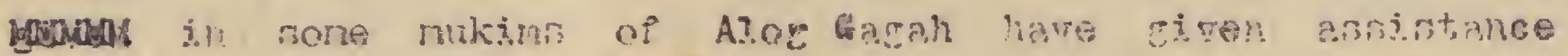
and a gool numer of thine of rocustis have heen hrought

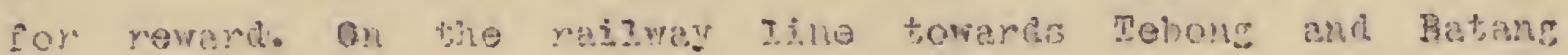
Halak they are remy lazy ant ring not he?p.

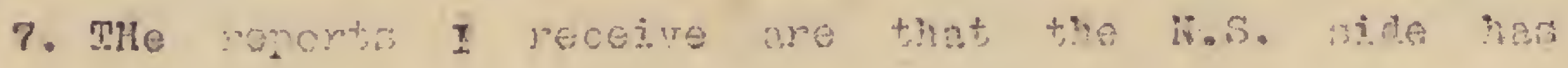

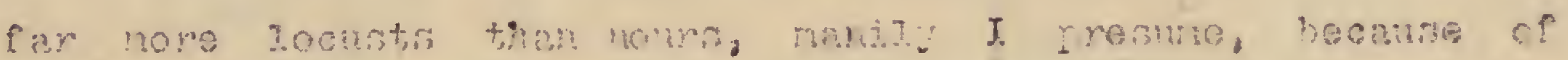

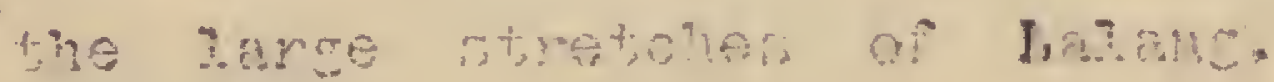

$$
\text { L.C.F.W. } 6.6 .14
$$

R.J.正. 2.6.

(4) To 4.5. F.Me.5. 16.6.14

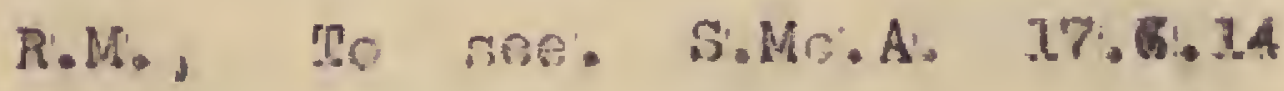

C.5. Seen. W.C.M. ta.6.

D.of F.

To ses.

S.M. A.

C.5. 


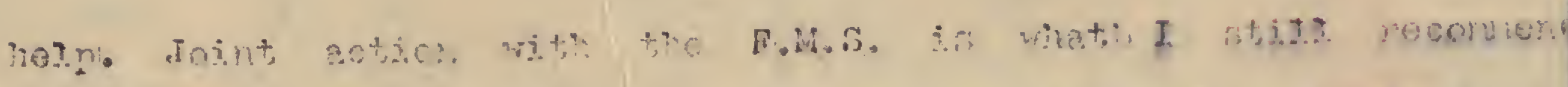

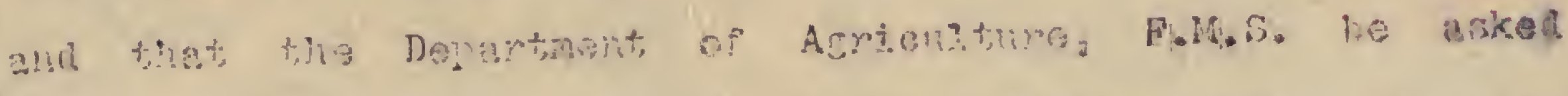

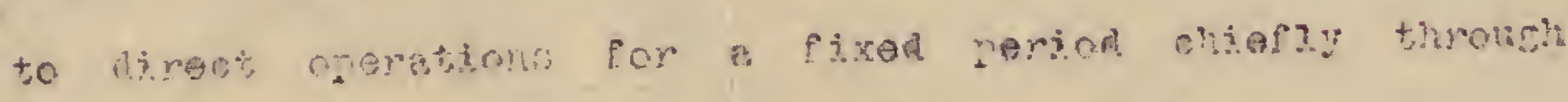
the borler rarel north of ATor gajah:

If the Doof 1. we.e arked (8) if he with accents the darection for two nonths and (8e) what iy men and

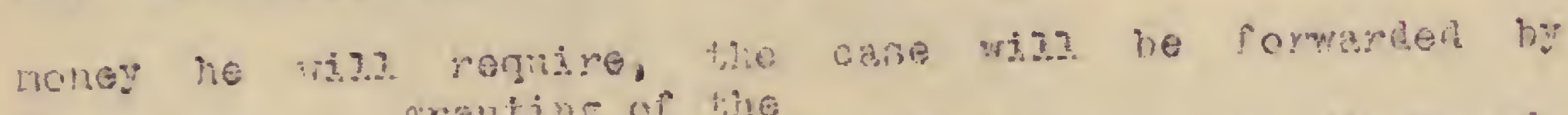

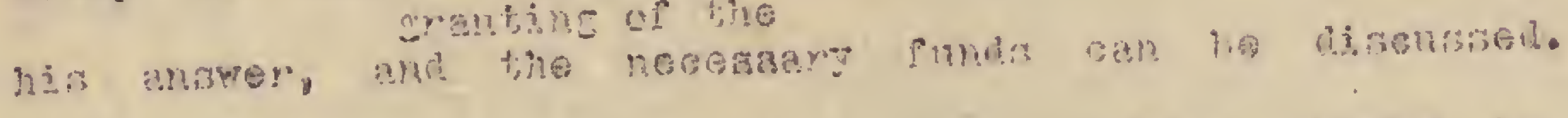

I an frtronty of mintom that monthing monk be cono for the isake of the cromeris of riee and coconutas

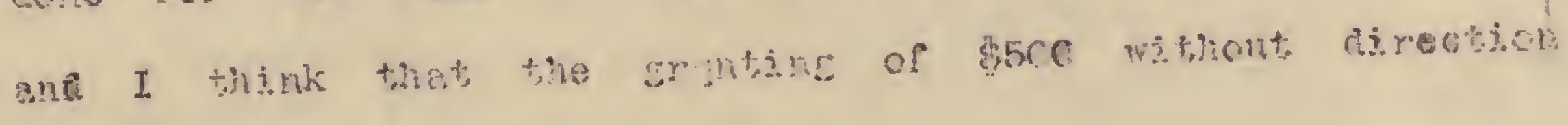
weis poyng wits the cese.

\section{H. B. 38.6 .3 .3}

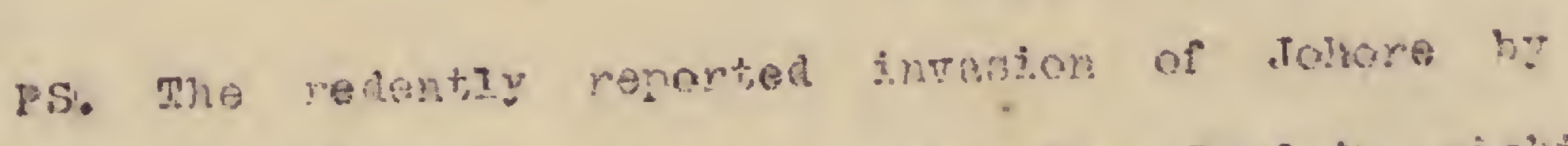

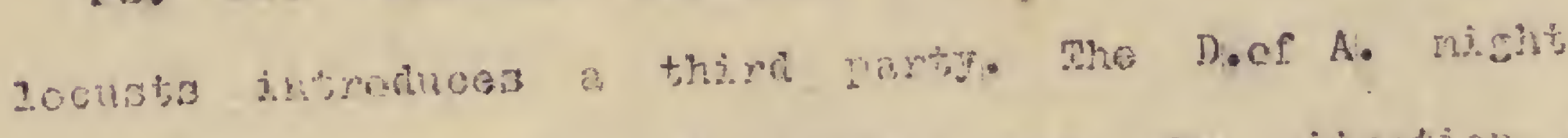
be erkol thronch his Governuent how the aituation in arfected bi it. I.H.B. 25.6 .94

\section{Y.F.}

I. agree whth the RoW. and the Doof ch that the

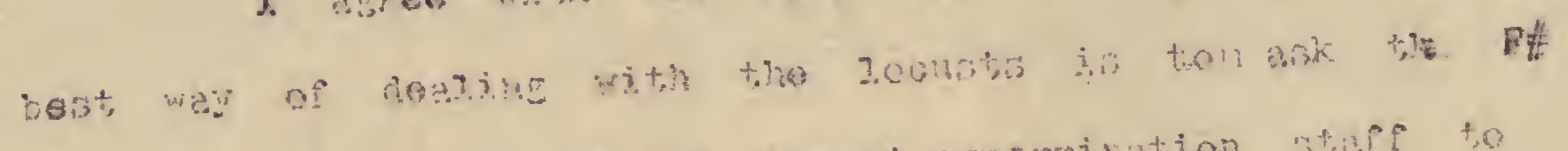

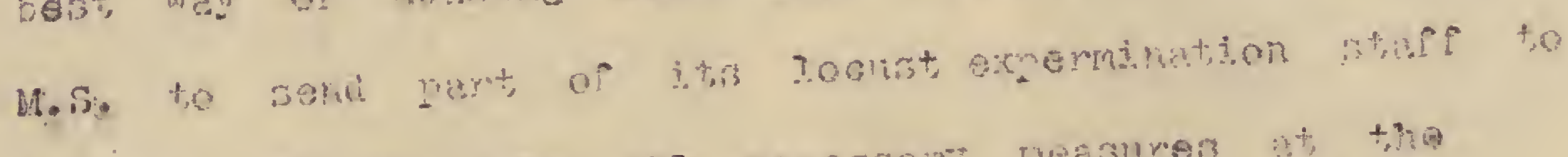

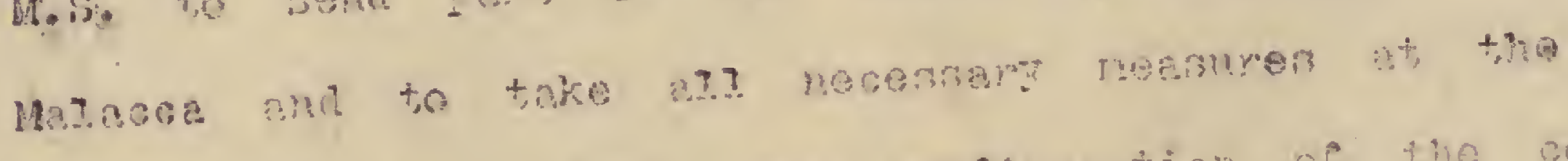

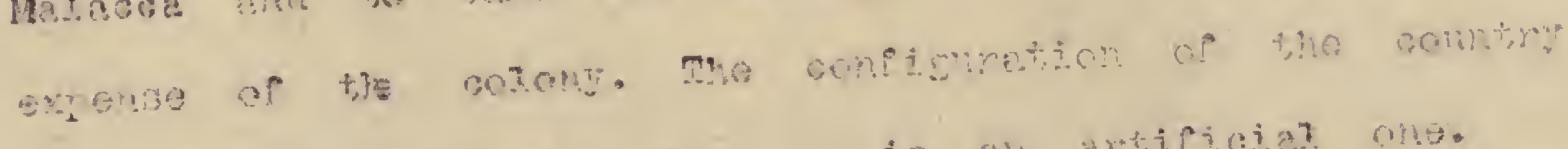

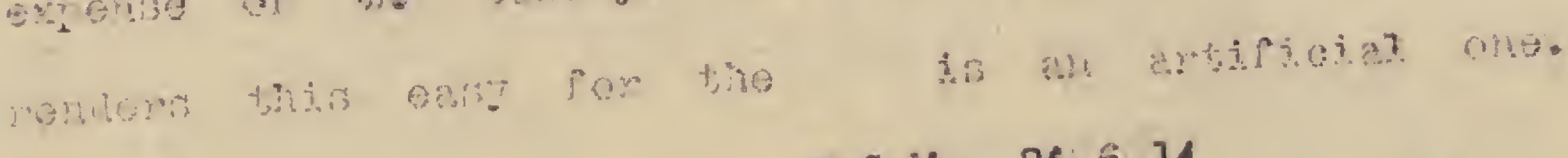

\section{W. G.M.M: $2,6.6 .74$}

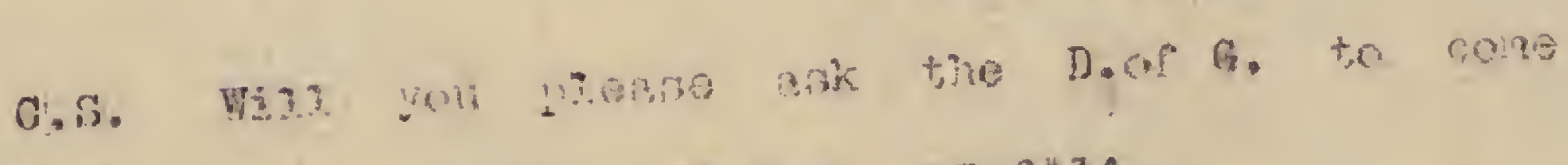

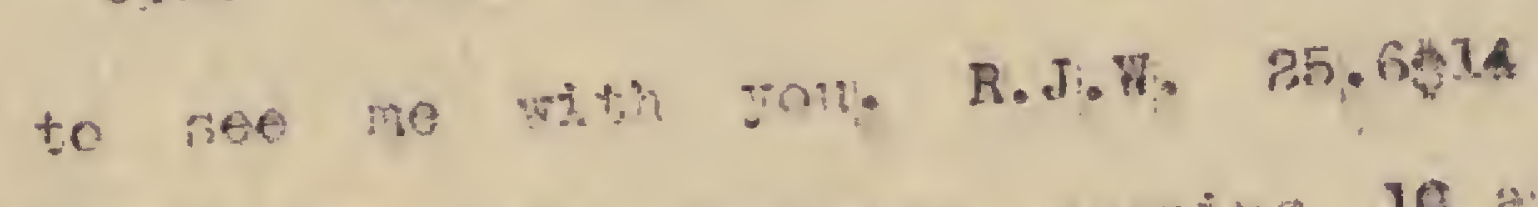

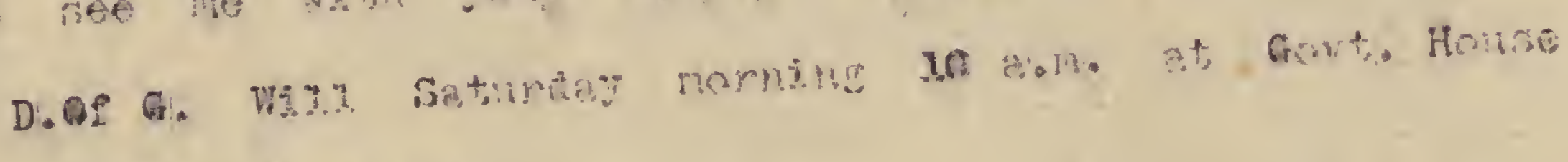
STit? Yon?: W.G.M.

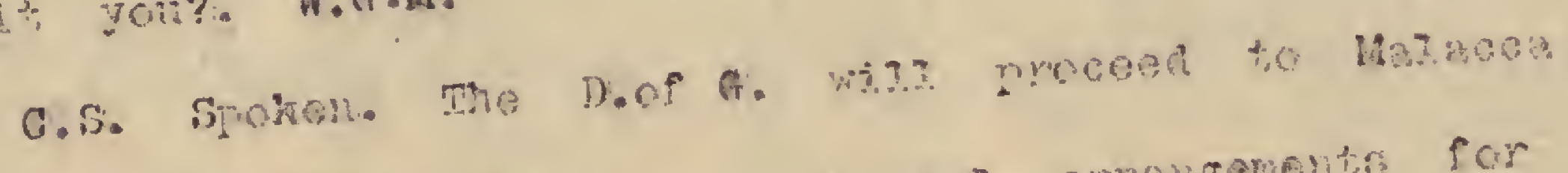

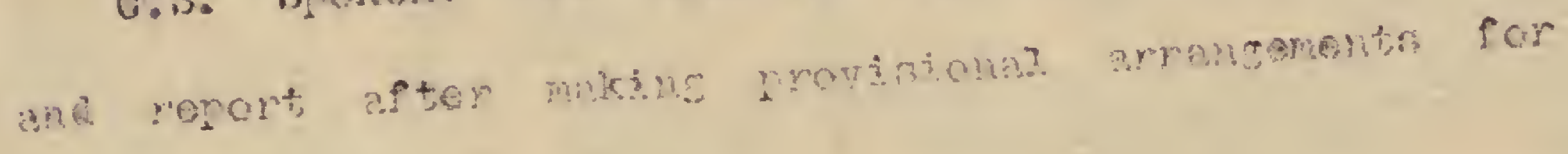




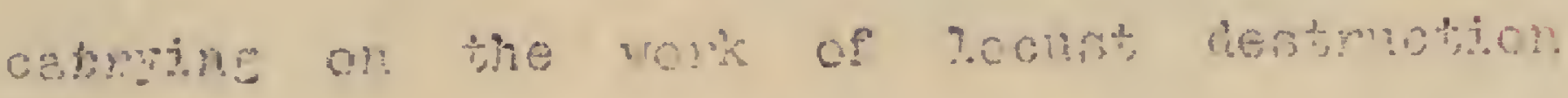

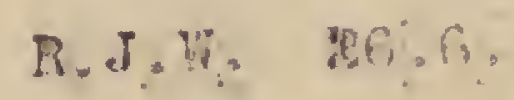

D. Of $r_{i}$

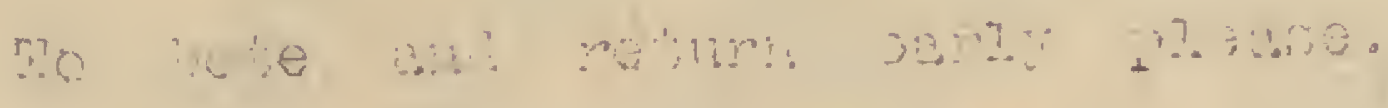

$$
\text { 1.6. }
$$

S. S. Kotoc

I. H.B. 27.6 .14

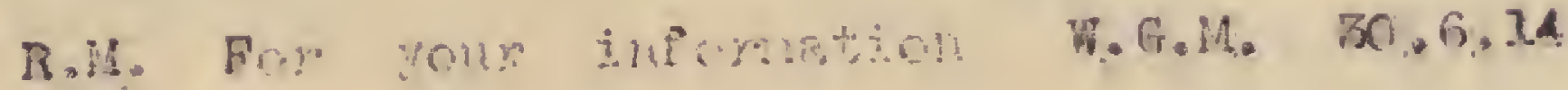

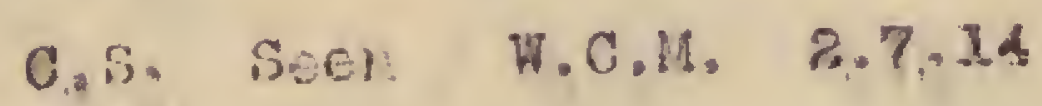

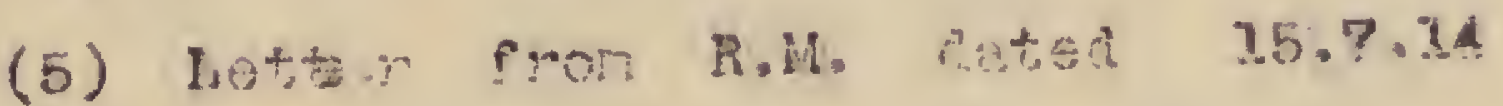

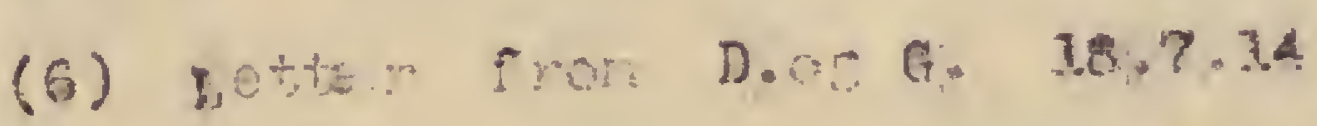

C.. 3.

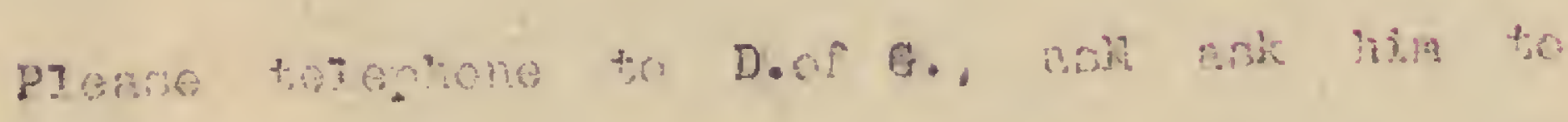

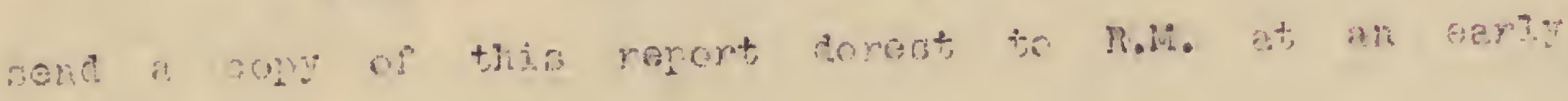

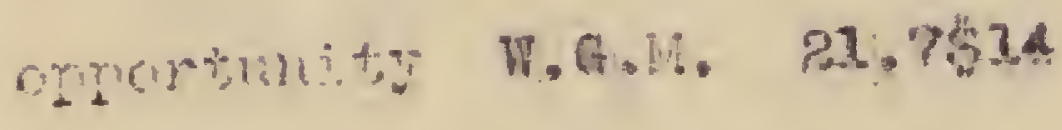

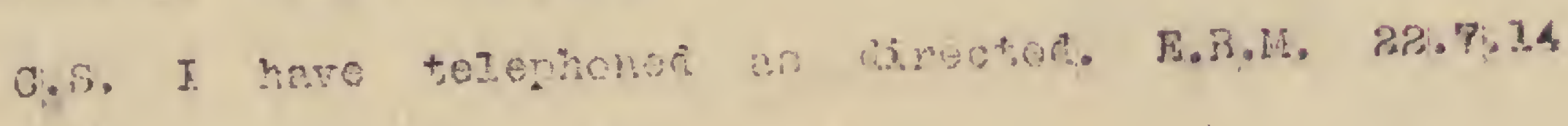

$D_{i=6}$

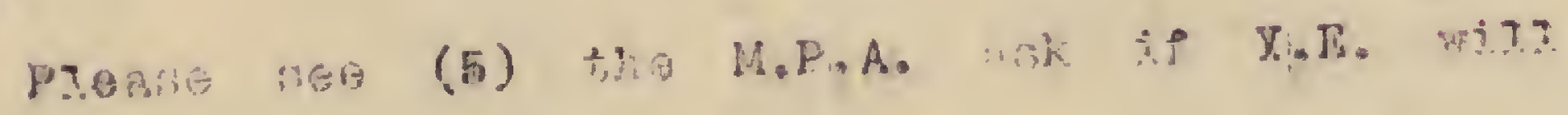

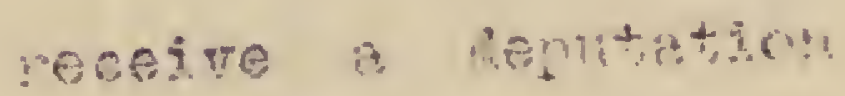

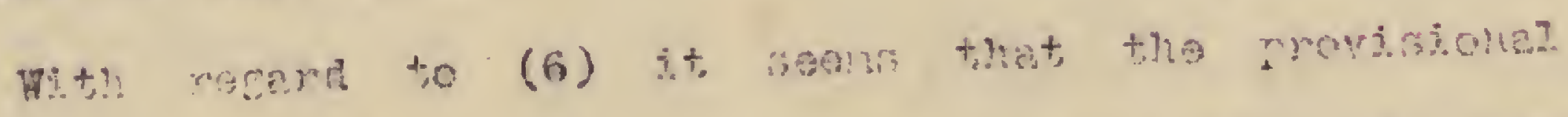

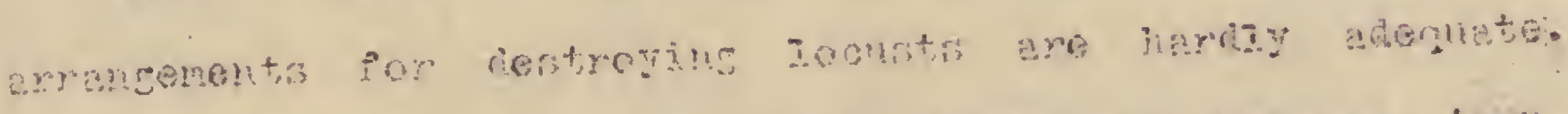

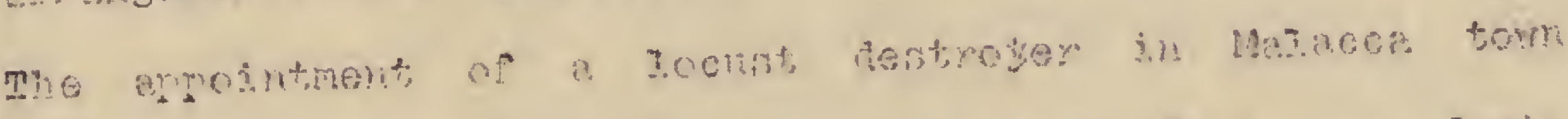

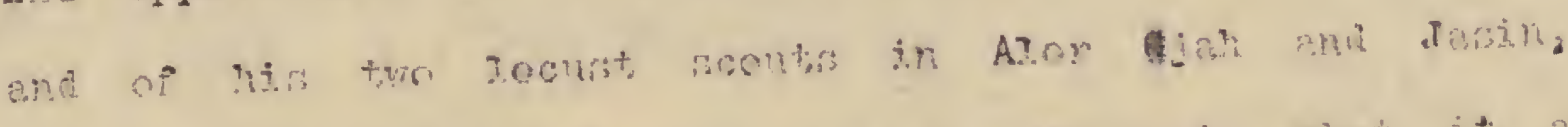

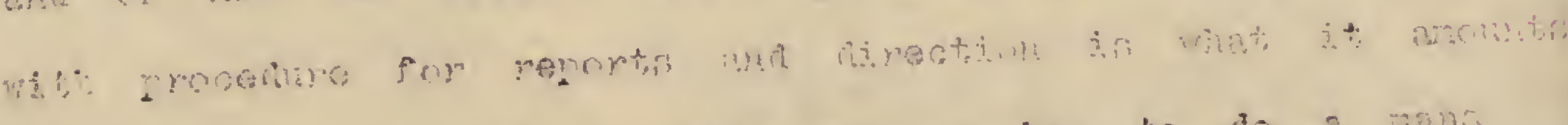

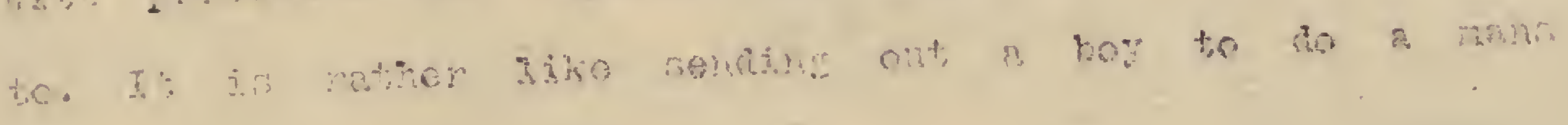
1ions:

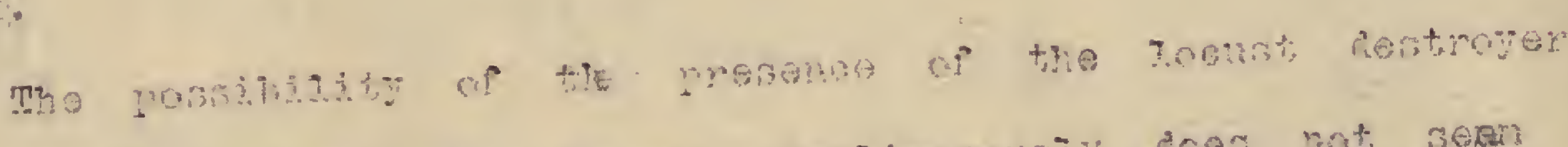

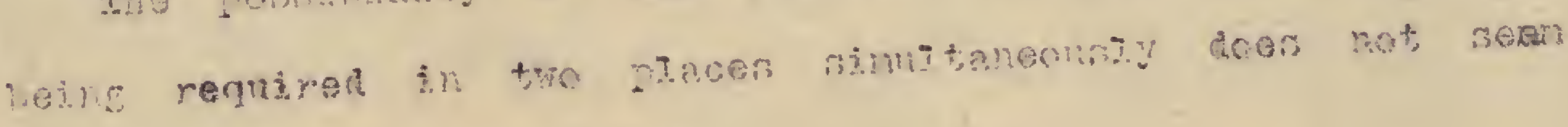
to have hoen aciseningted.

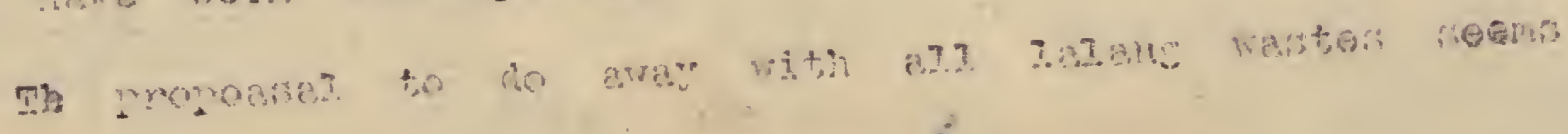




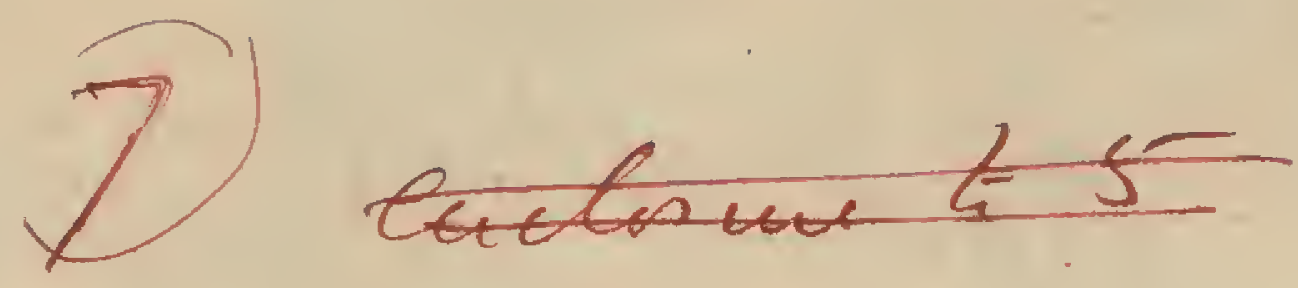

To nesidant MaI20ca.

I an director by the o.A.g. to rentert, you

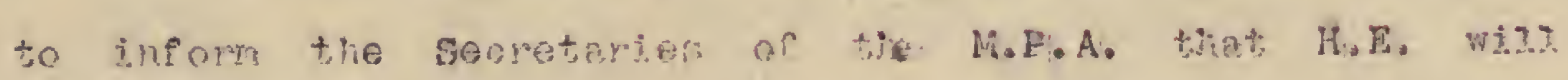
be elar to recoivo a demptetion from tham at any time either in sincerane on the 8othe Just Int. Angust; or

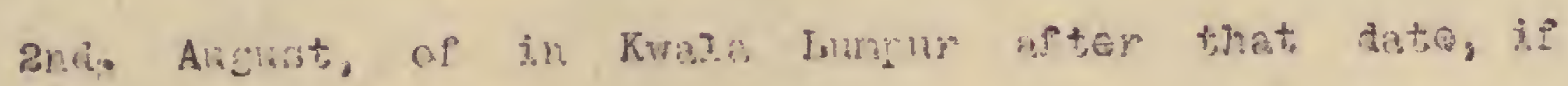
tie Derutition wine inform hin in adrance of the dato of the in cominge

2. In the montine they wist he intereater to know that the D. of $A$. hars heen aproncher hoth direathy

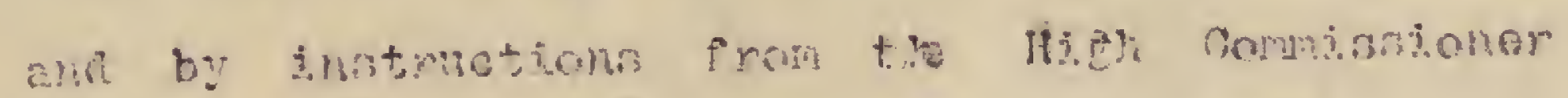

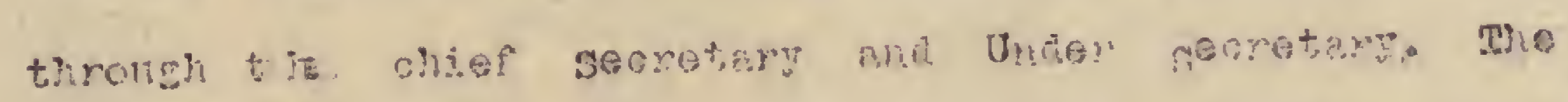

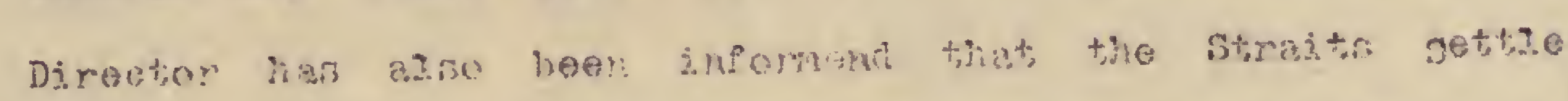

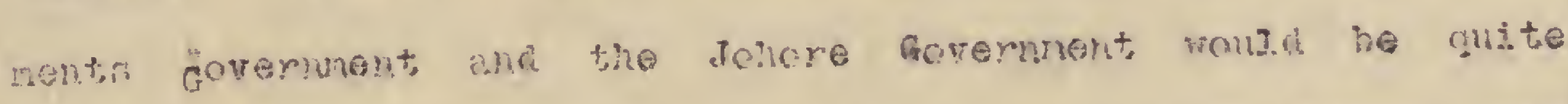

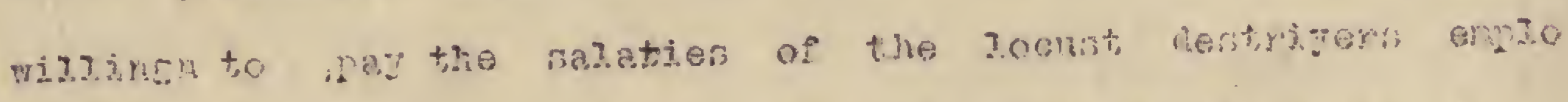

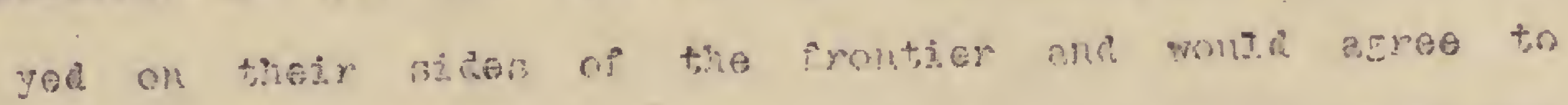

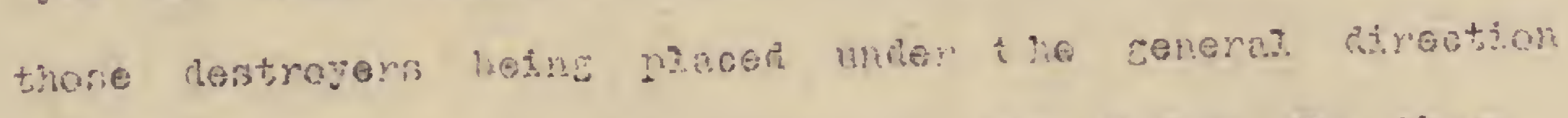

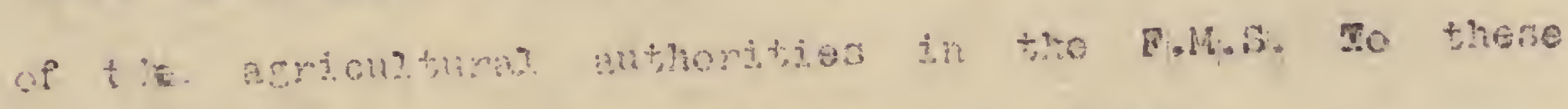
pronosens he renty has zet heen recestred,

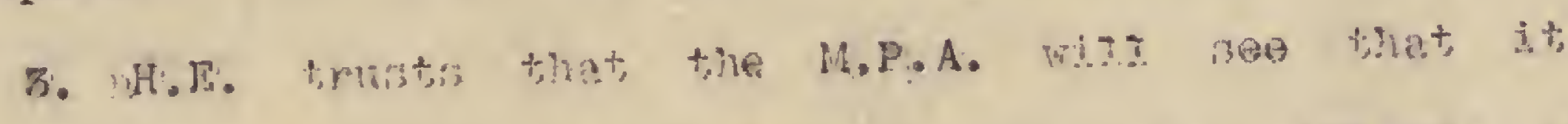

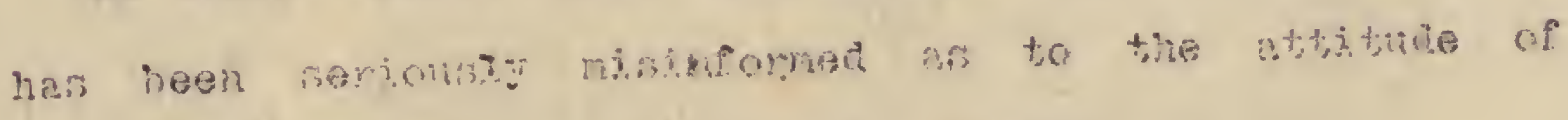

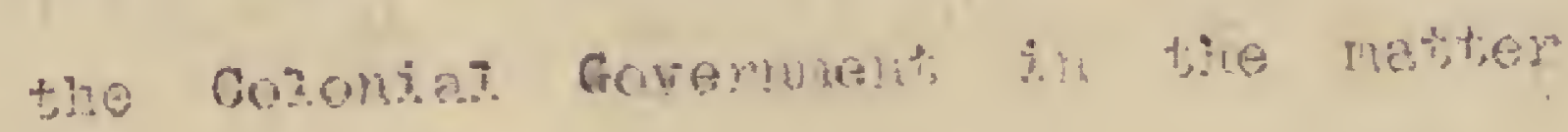




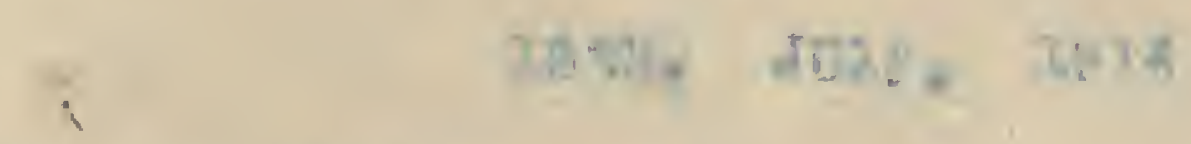

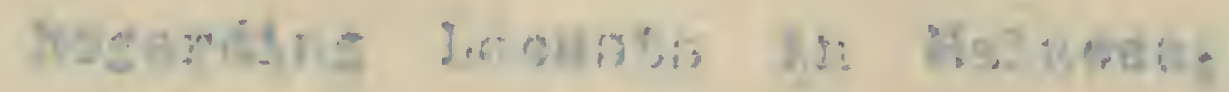

aII.

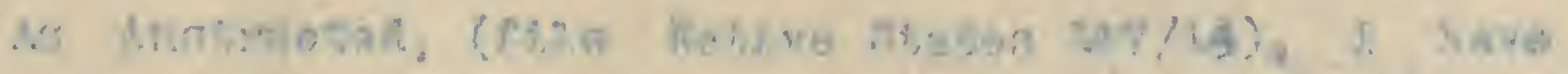

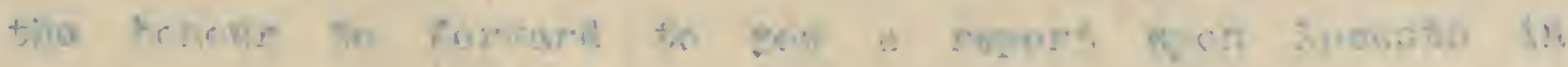
Xhas anpas,

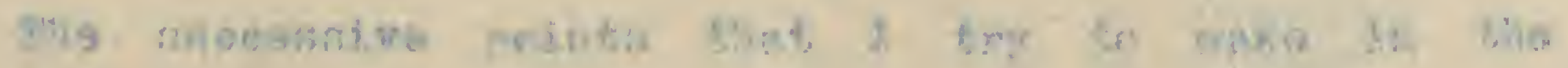
Engert, Fran

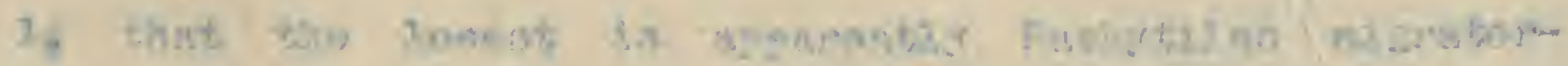

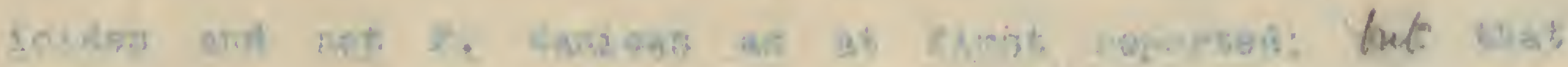

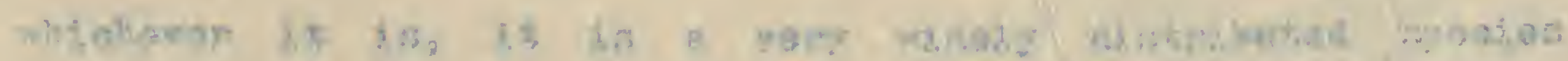

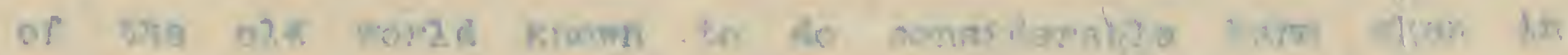

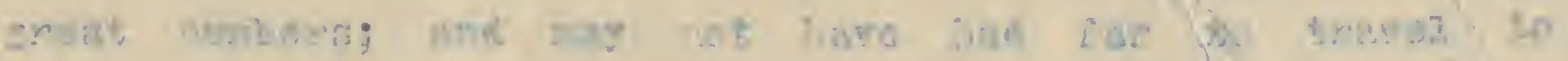

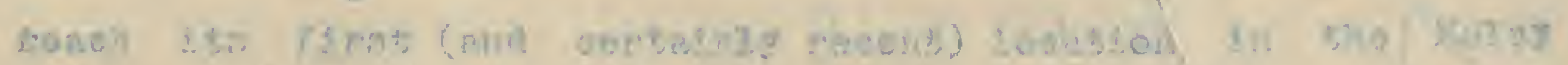

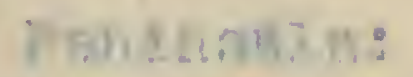

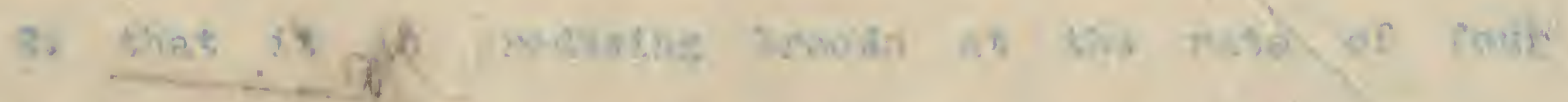

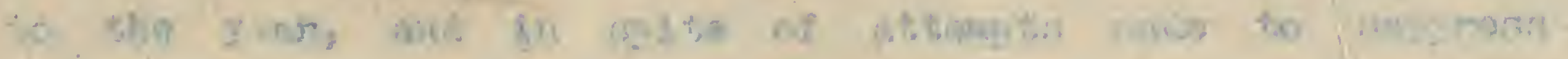

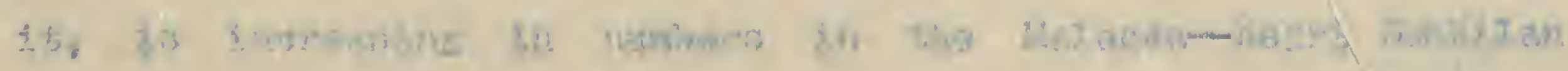
region:

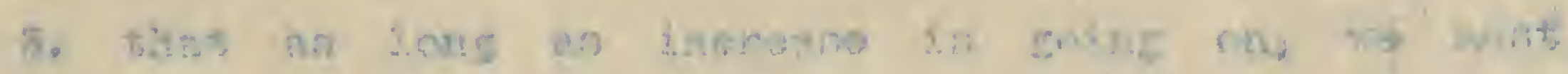

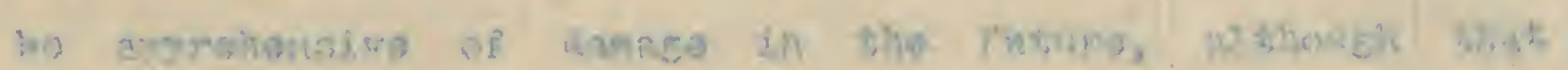

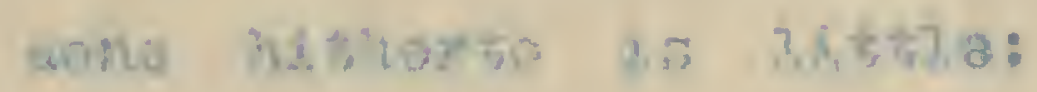




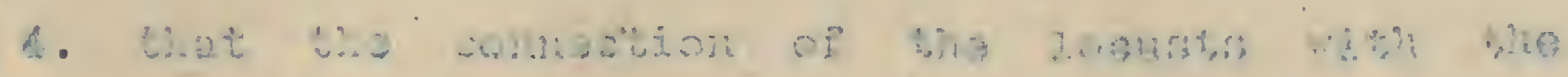

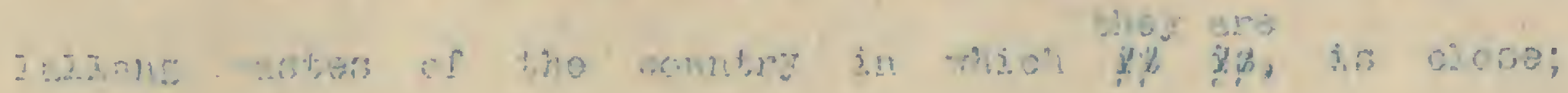

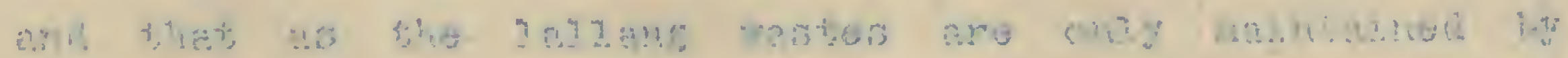

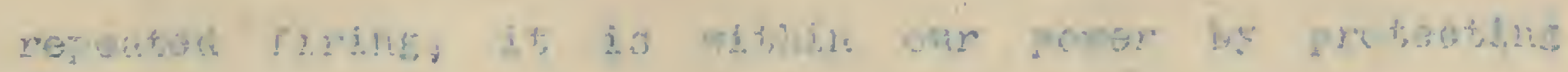

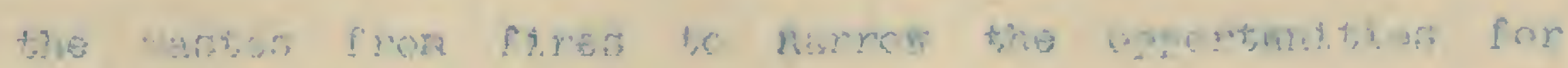

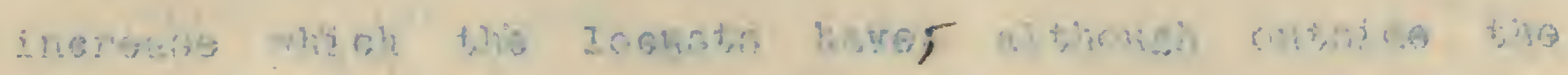

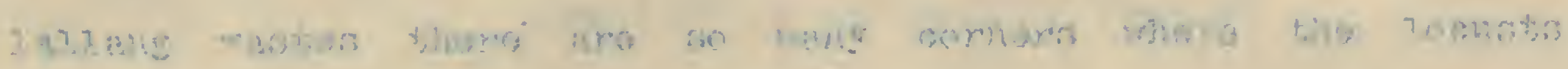

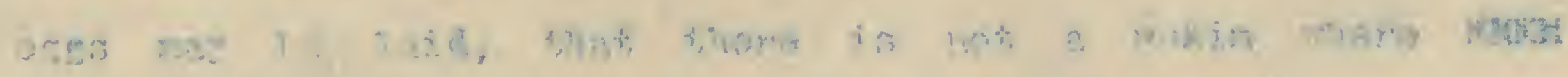

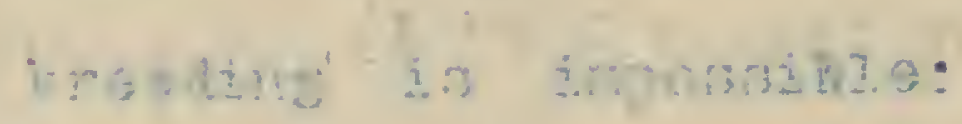

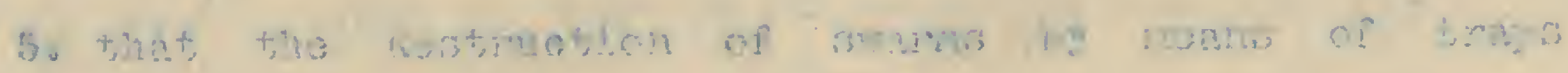

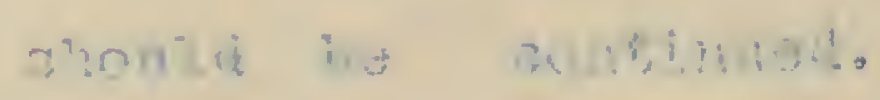

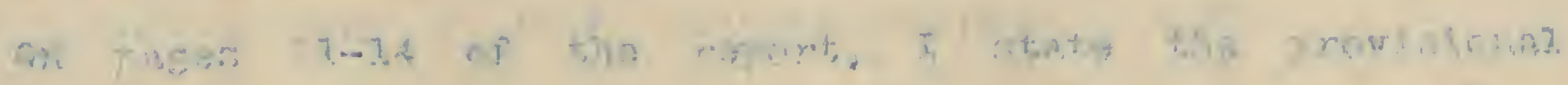

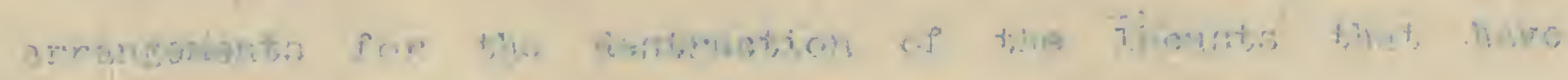

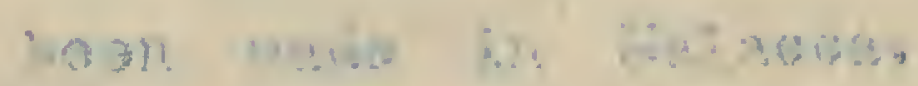

+4 .

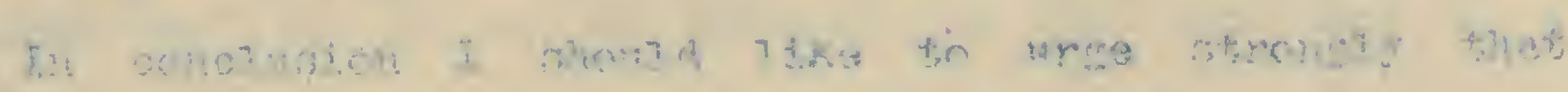

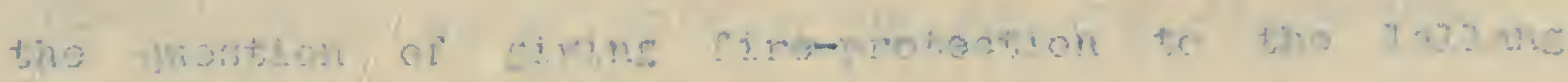

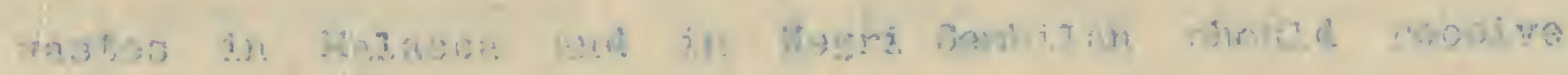
coringusysuther.
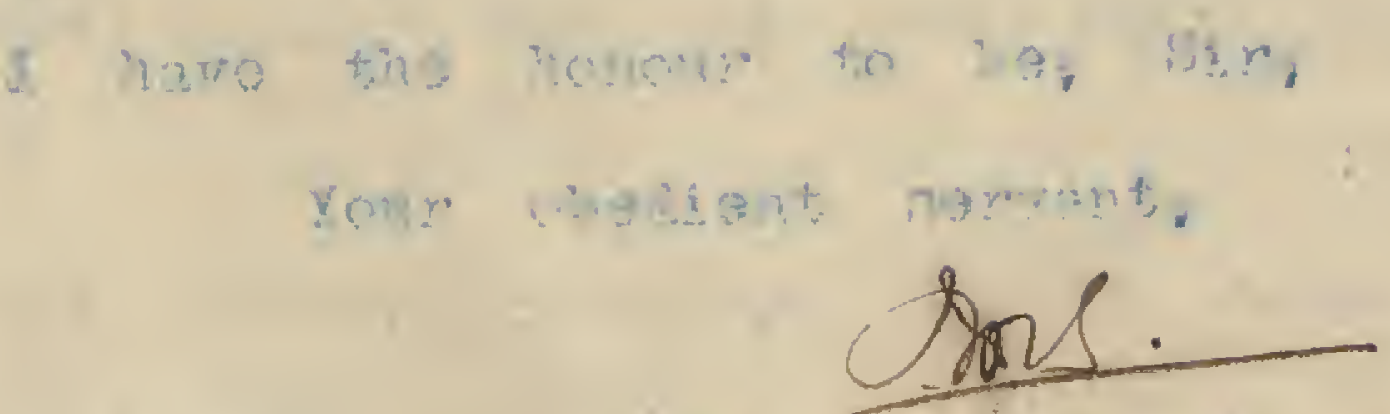

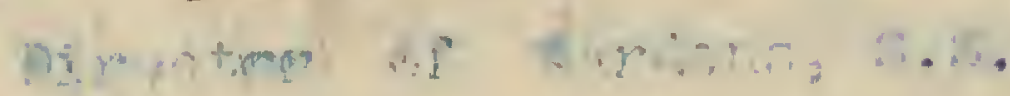




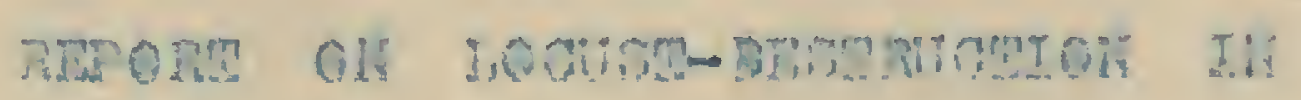

MAIACAA TPRBT CORY.

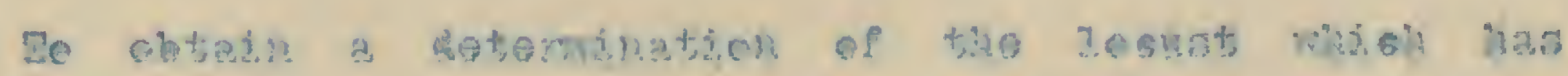

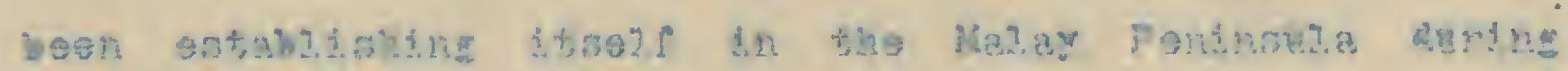

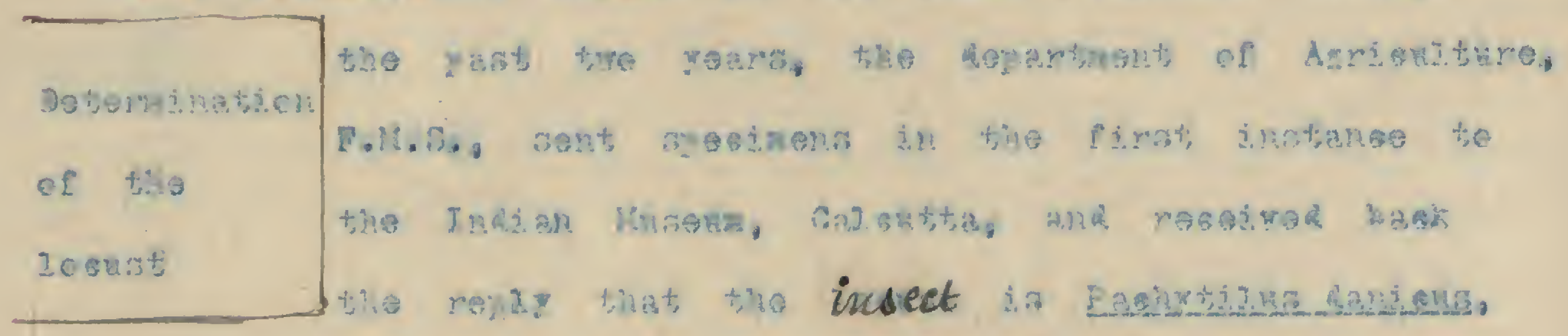

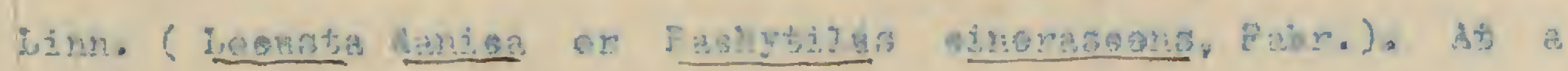

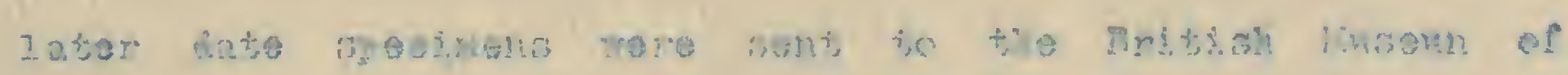

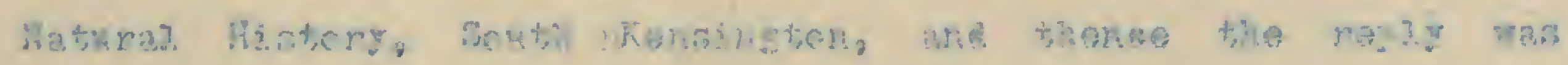

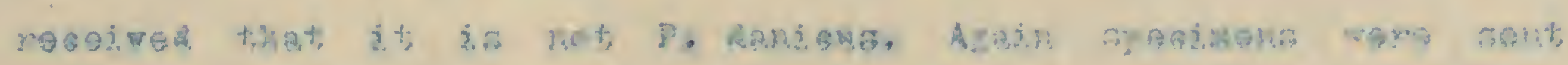

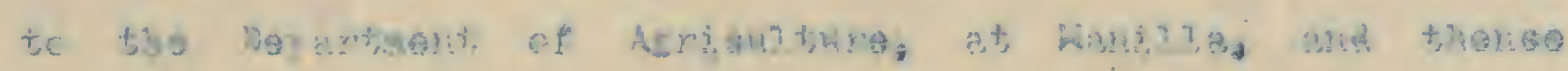

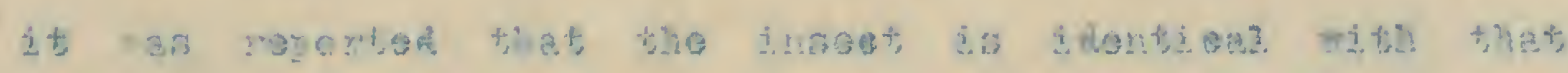

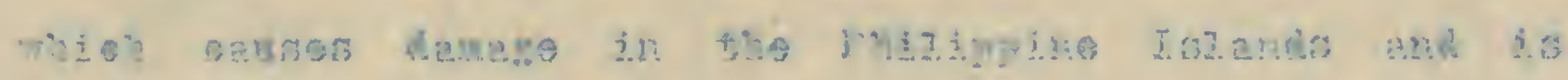

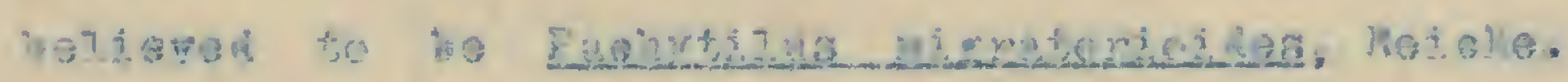

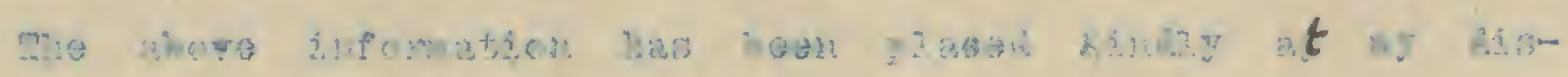

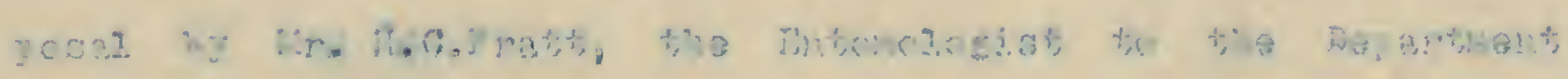

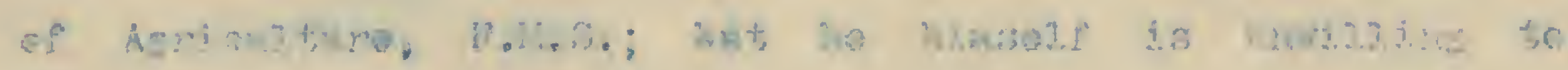
give a now to the ingegt,

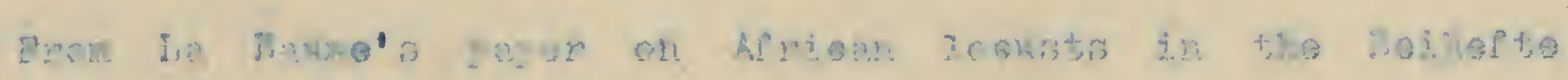

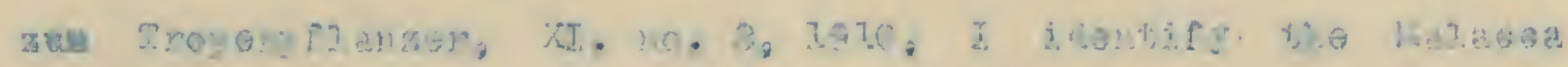

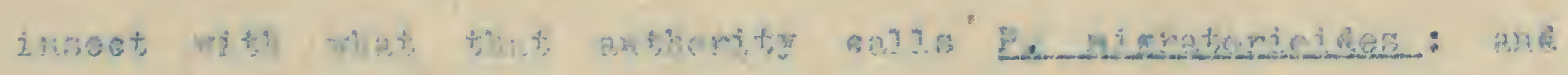

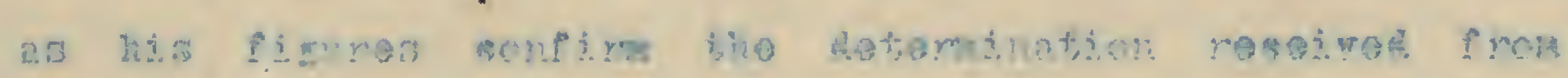

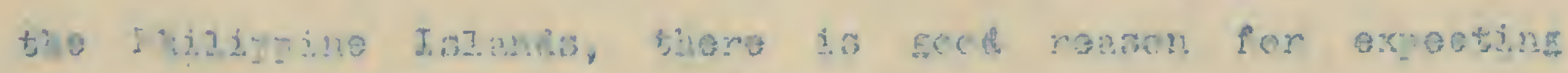

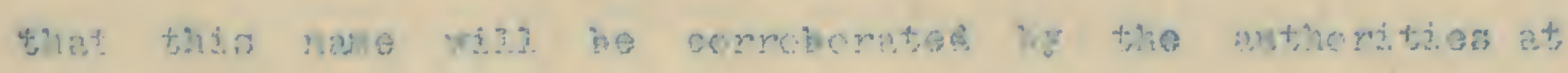

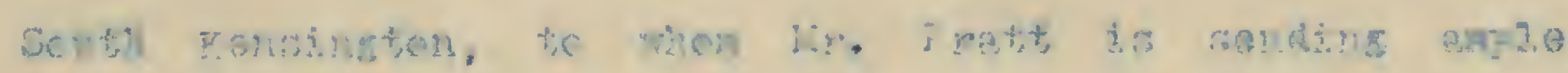

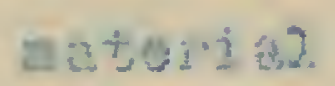




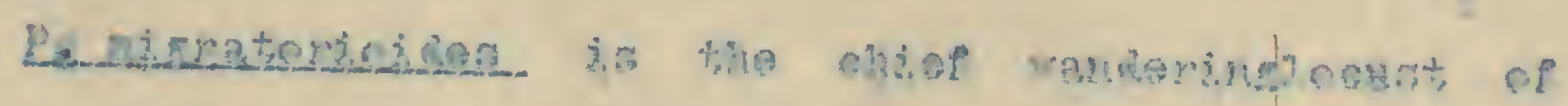

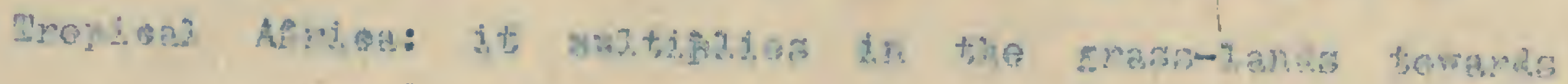

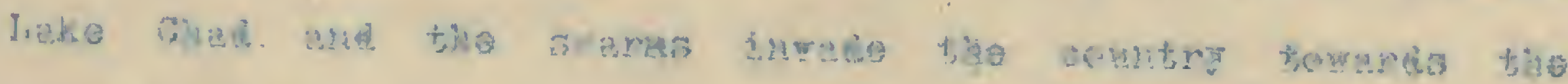

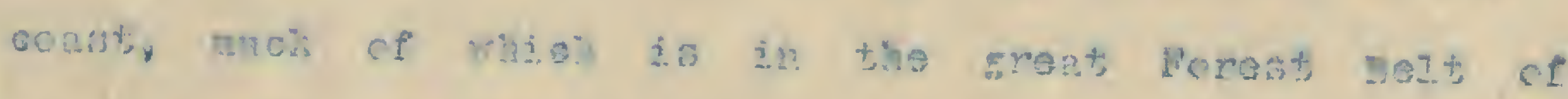

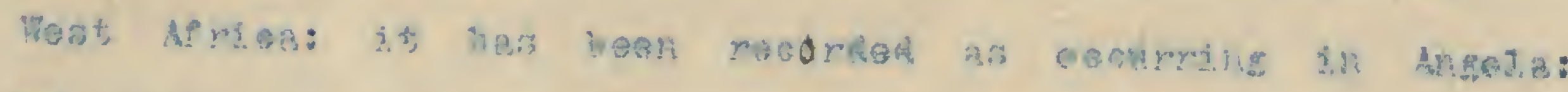

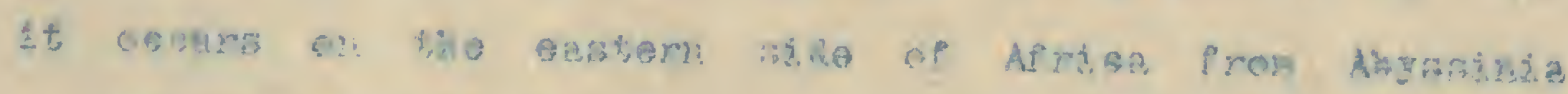

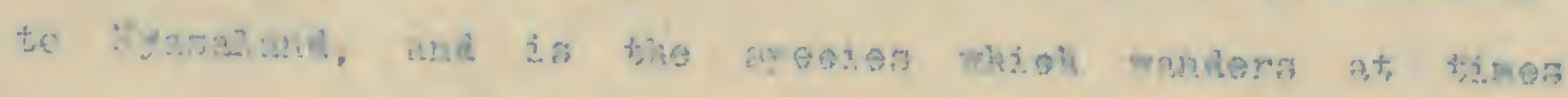

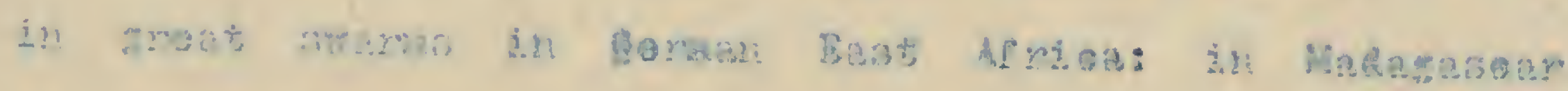

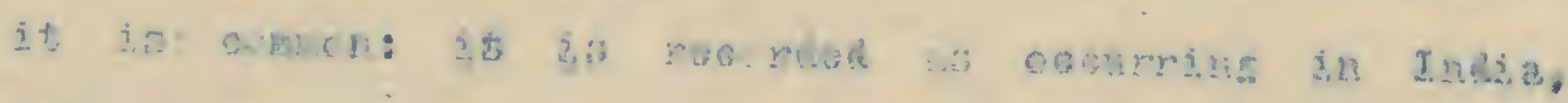

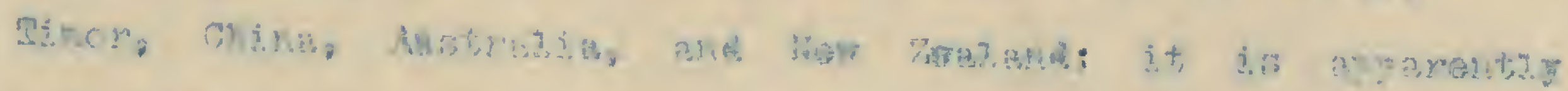

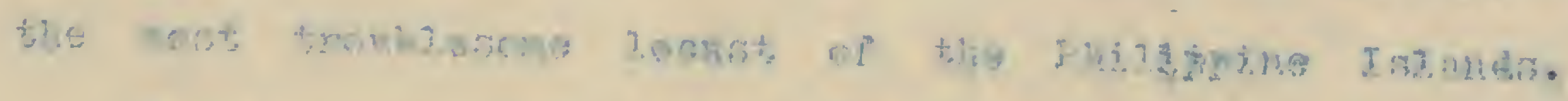

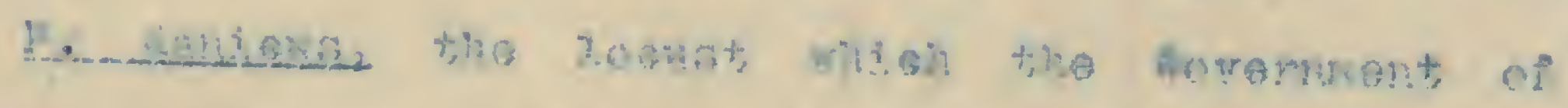

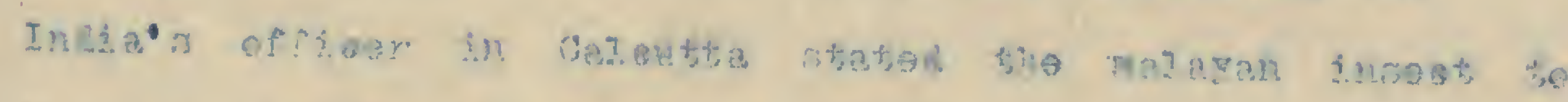

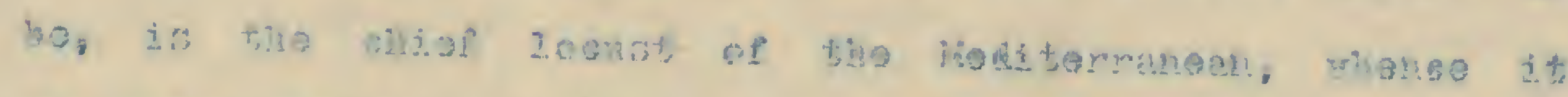

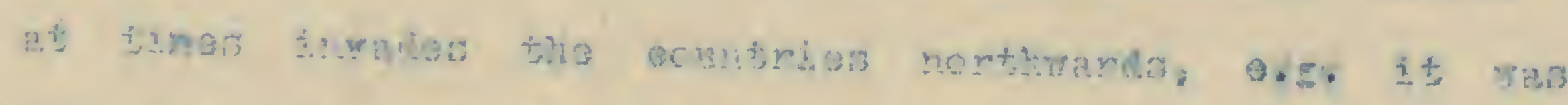

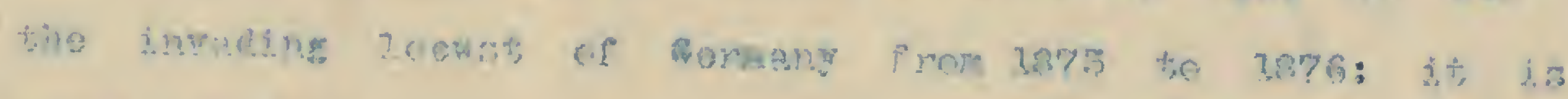

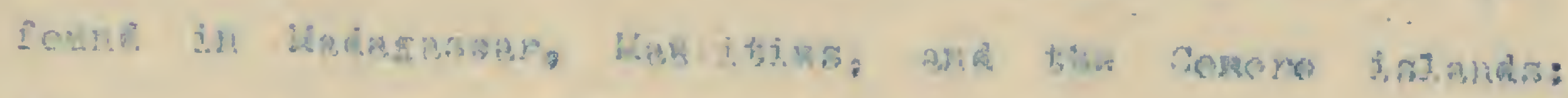

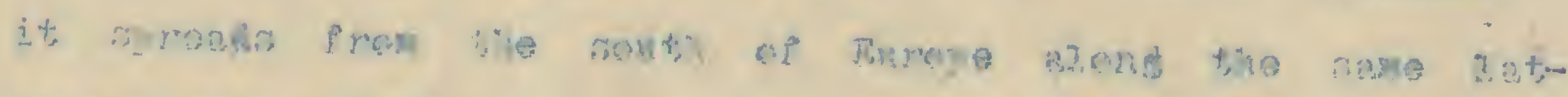

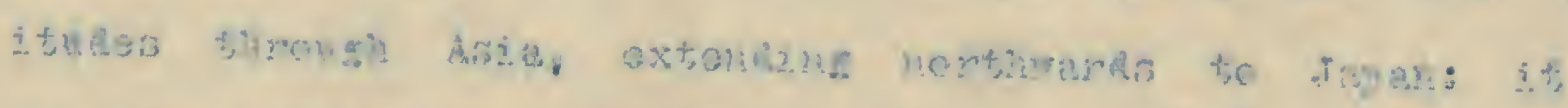

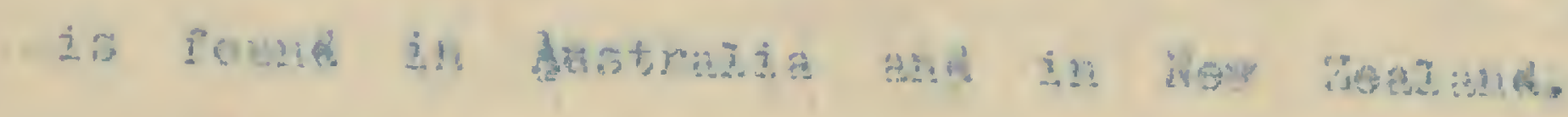

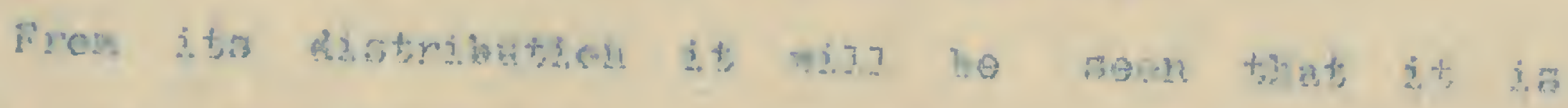

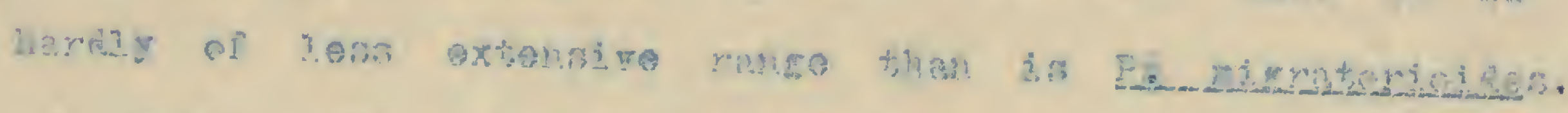

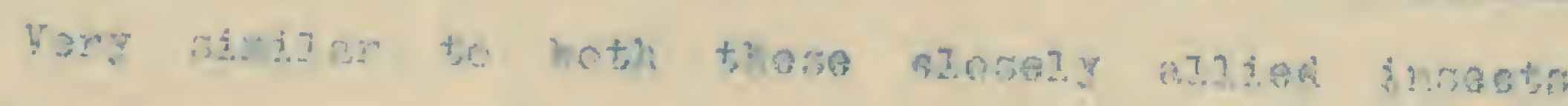

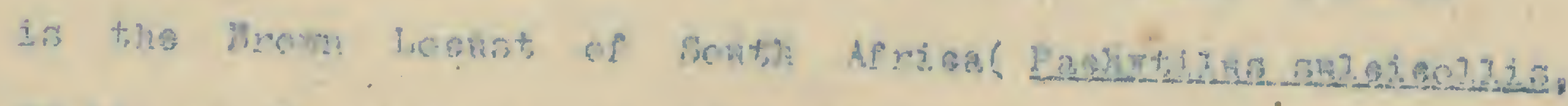

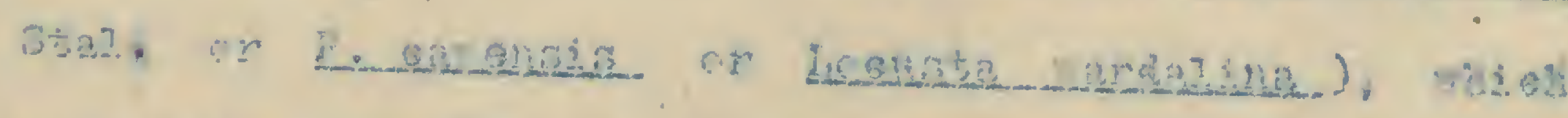

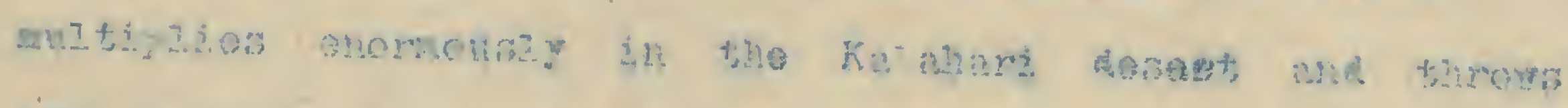

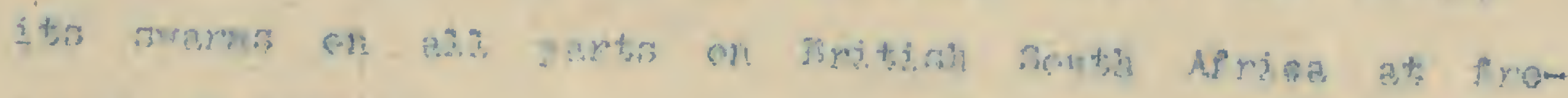
ment; intarsoles. 


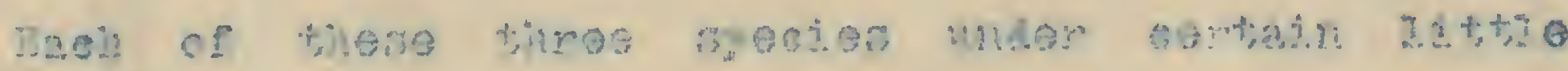

uncustaro

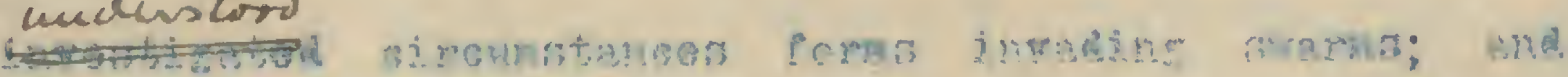

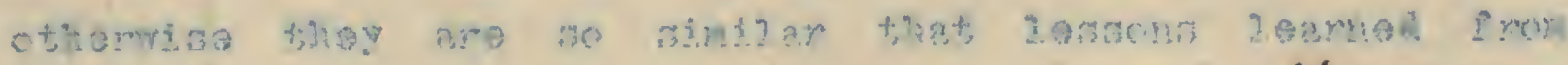

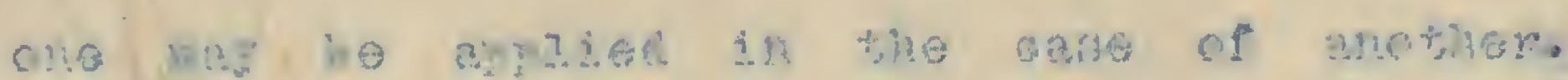

Hovever.

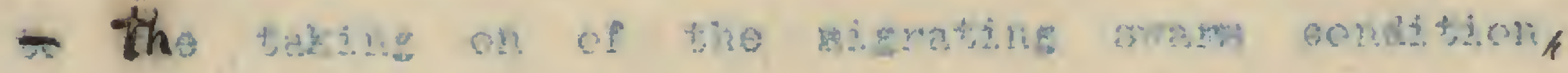

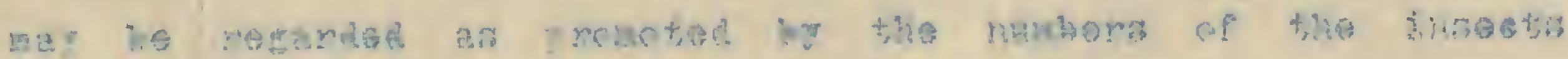

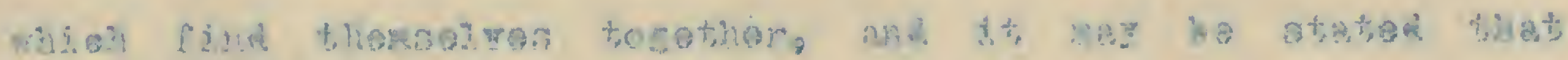

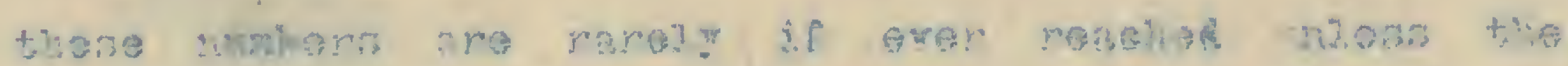

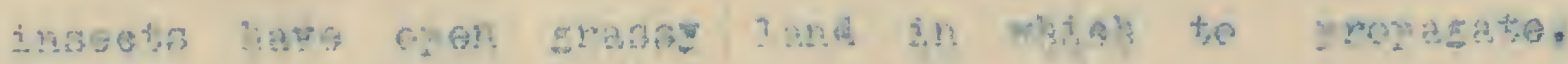

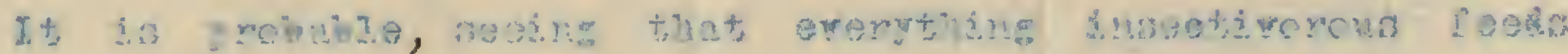
on Iocusta mien the chanee scwes, fiat their ereat,

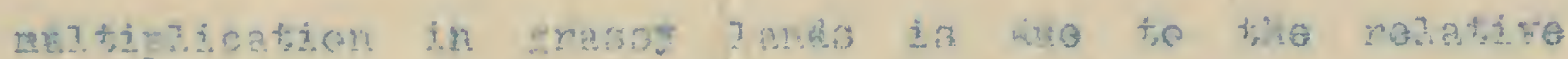

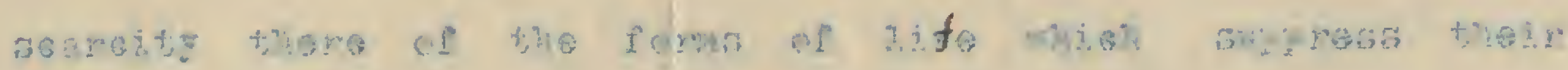

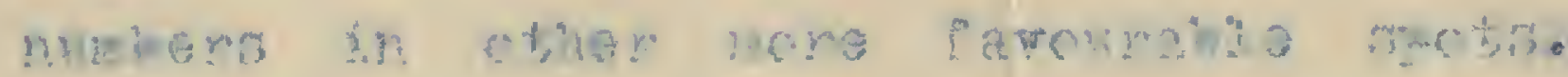

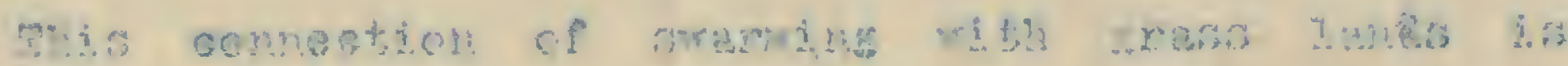

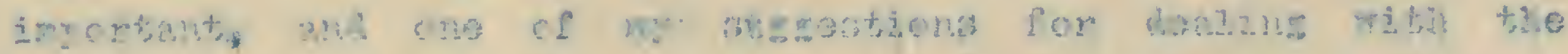

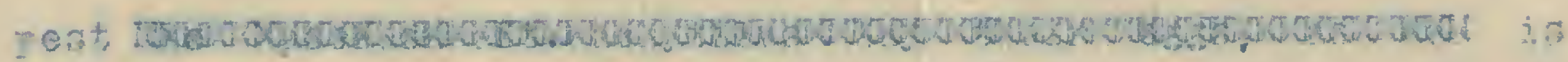
ivasen al: its.

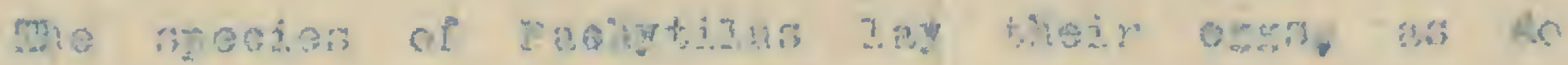

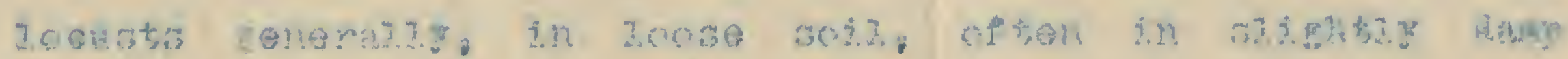

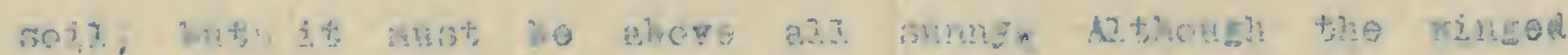

miore
hosensing
cosurs.

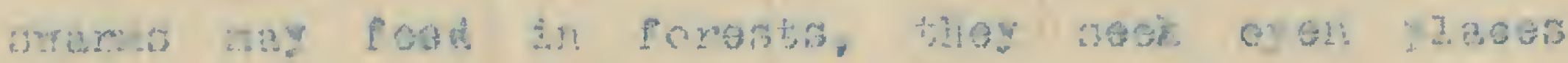

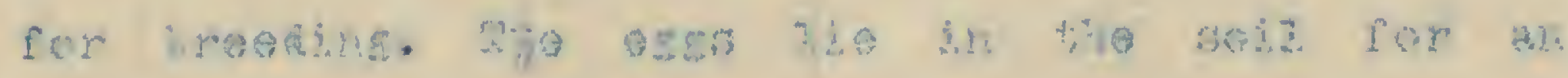

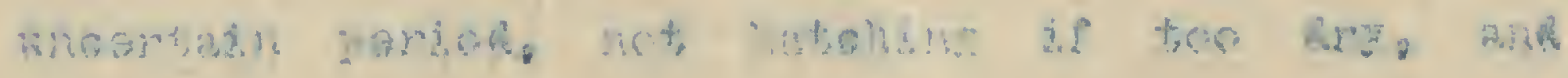

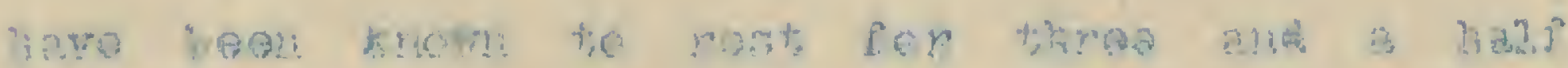

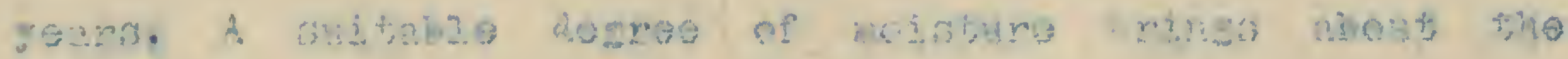

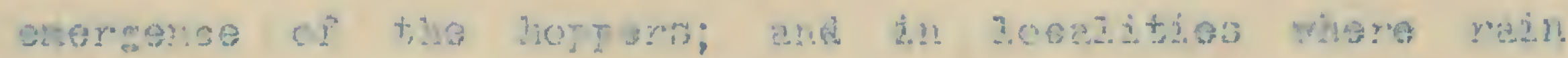

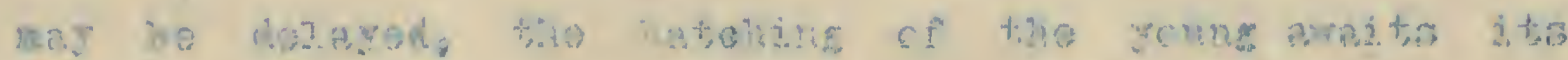
echine.

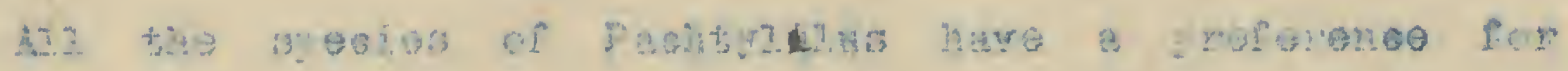

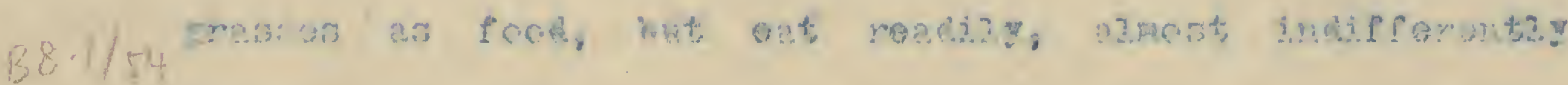




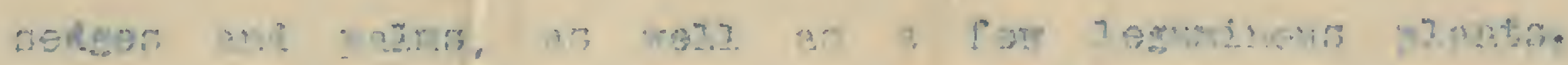

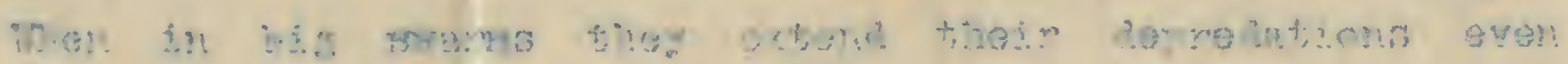

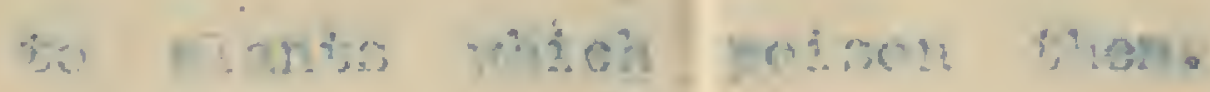

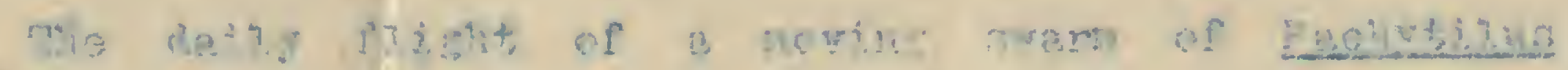

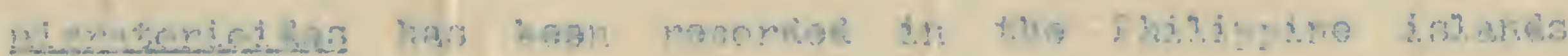

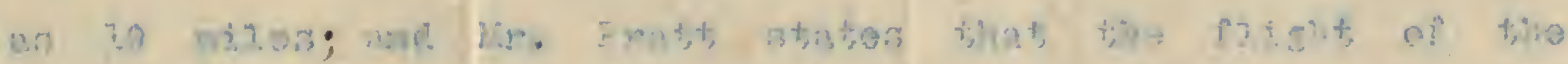

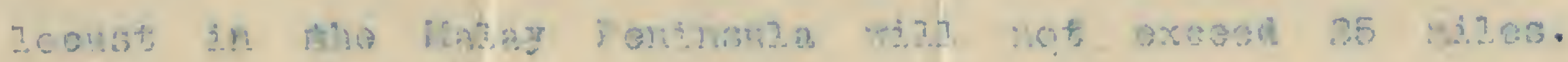

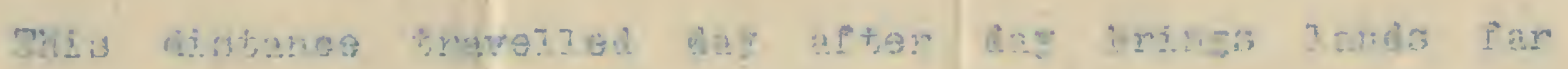

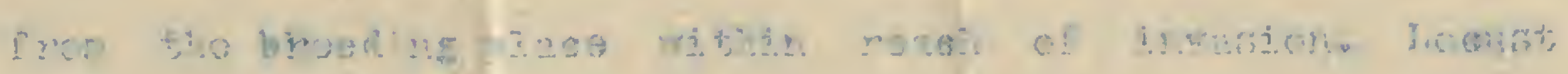

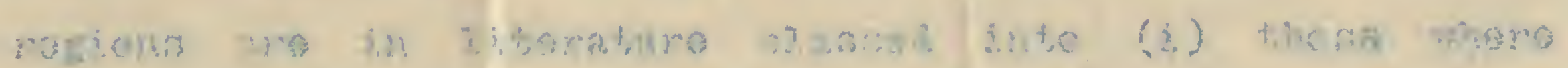

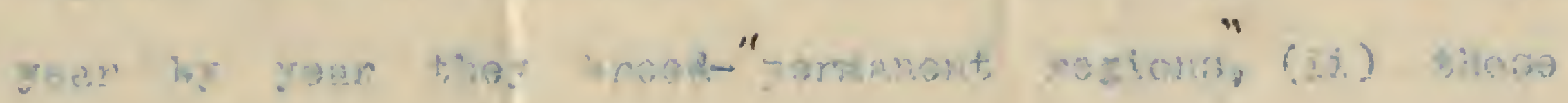

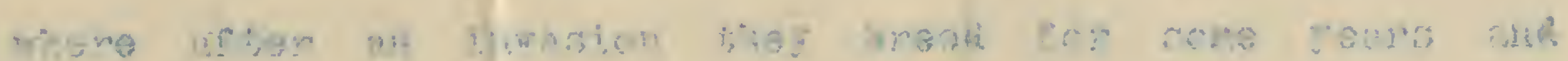

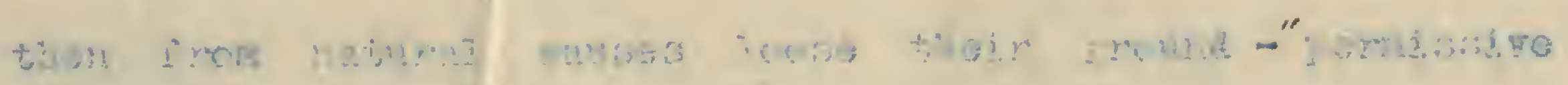

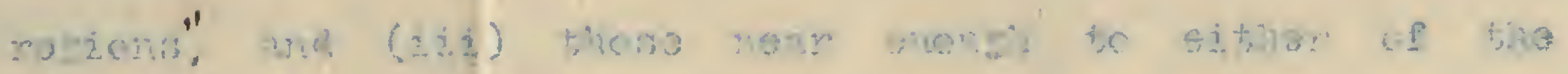

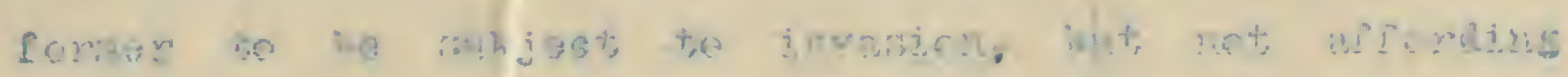

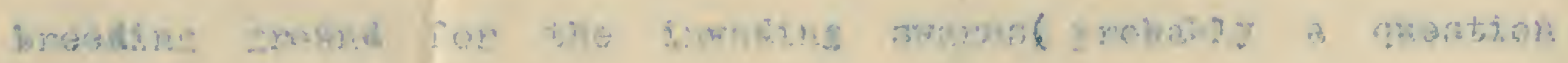

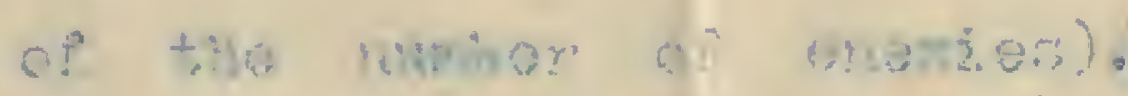

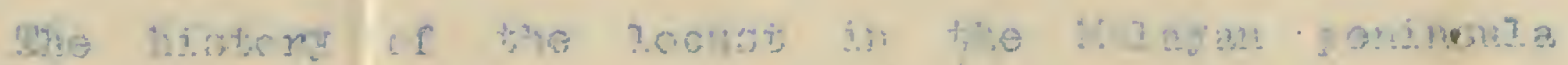

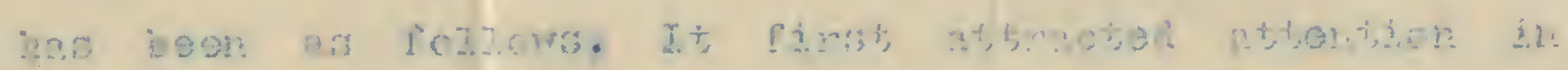

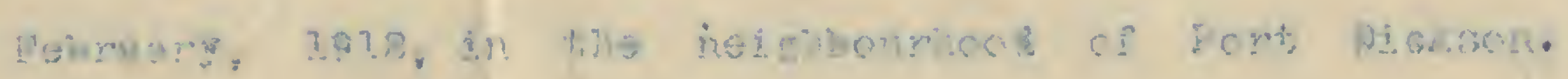

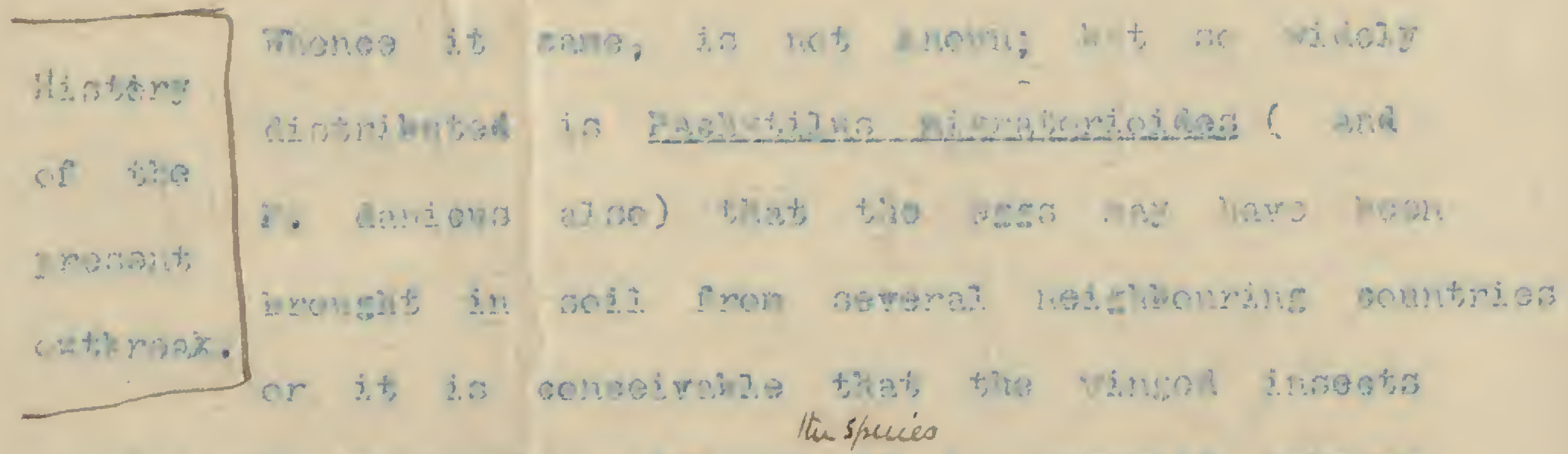

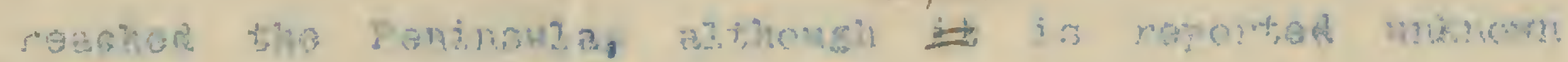

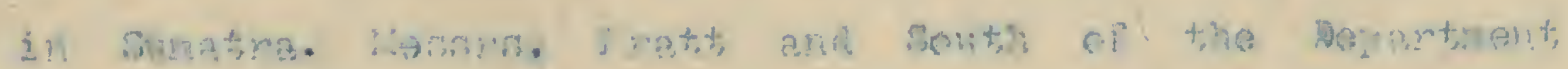

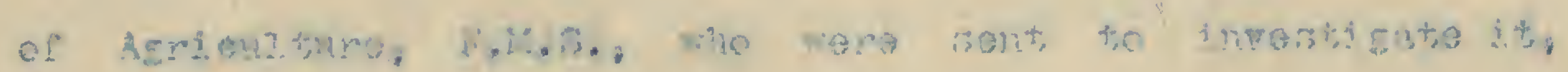

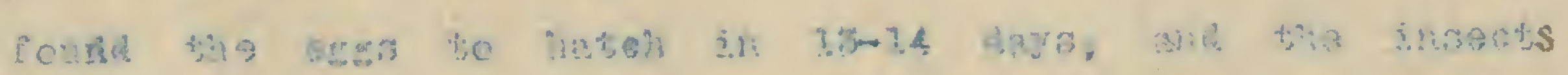

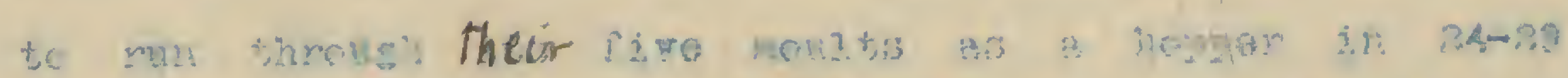

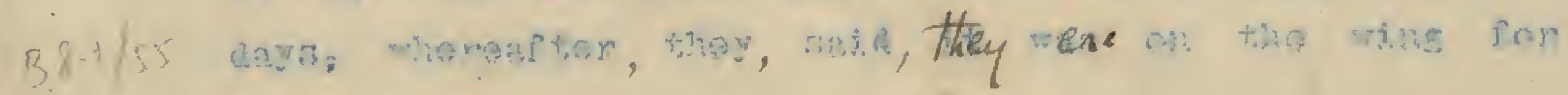


timso nontis, derien which they become

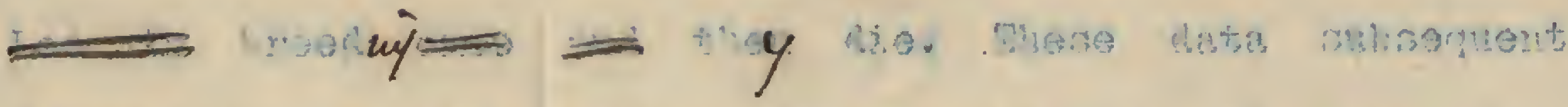

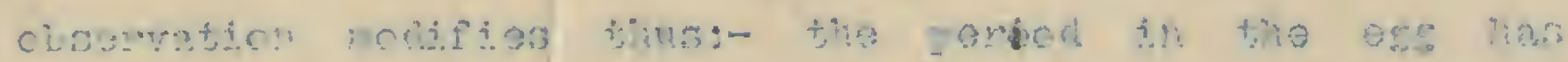

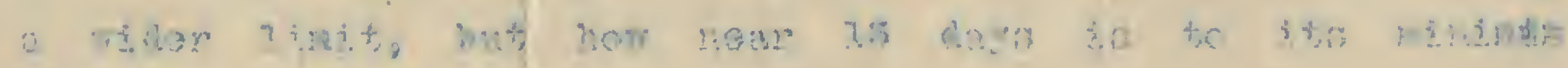

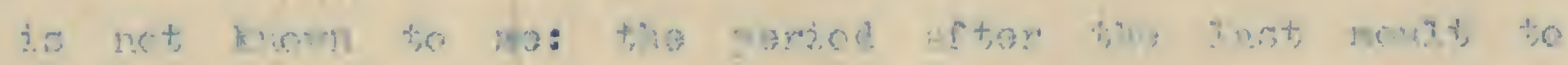

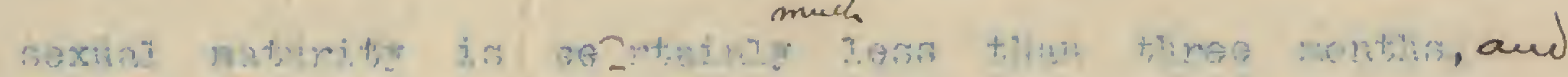

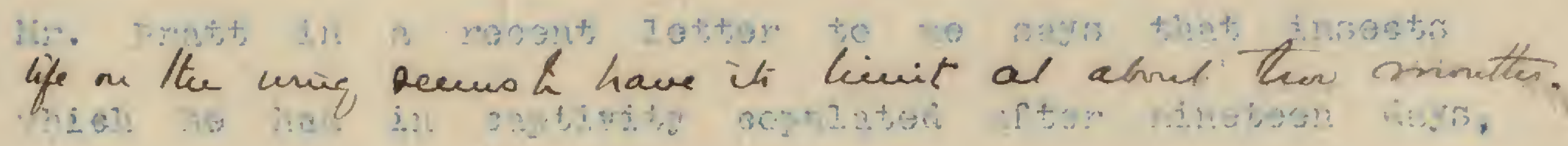

9 3

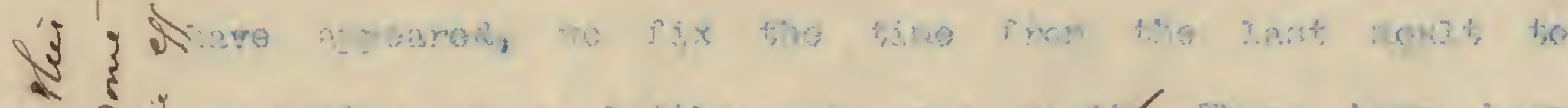

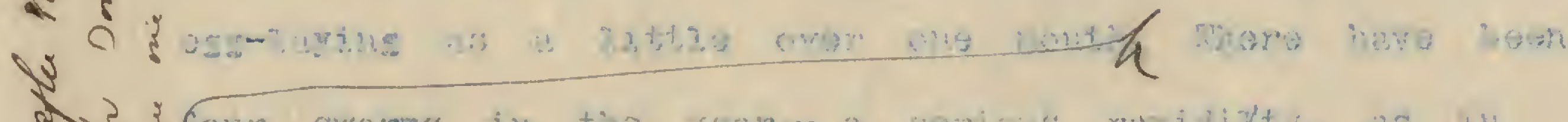

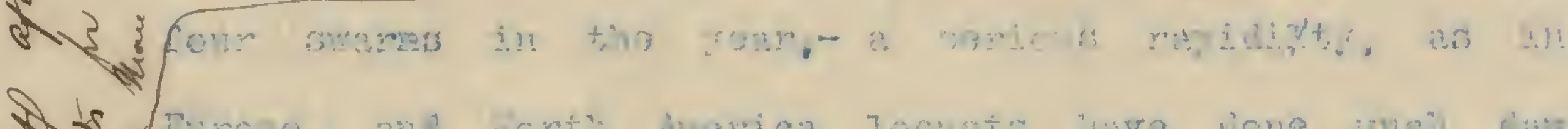

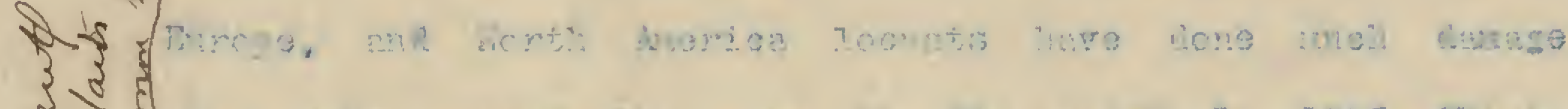

\{ $\begin{aligned} & \text { a } \\ & \text { e }\end{aligned}$

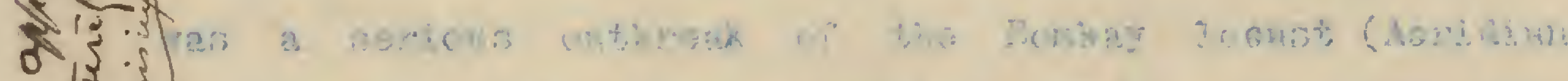

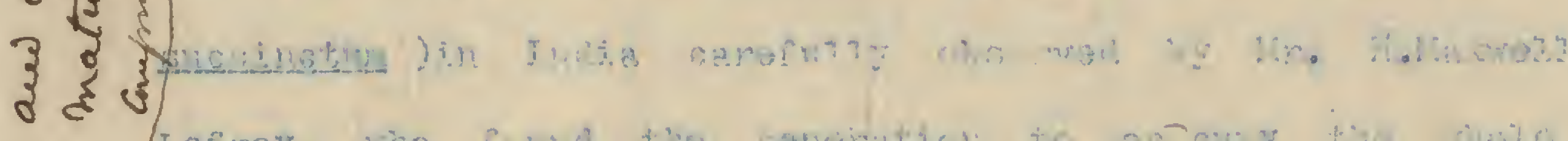

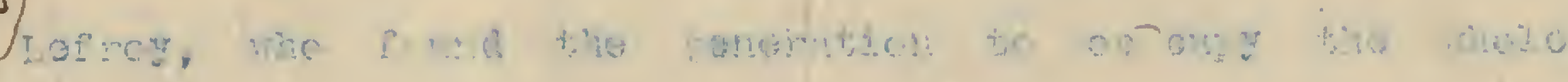

Joar.

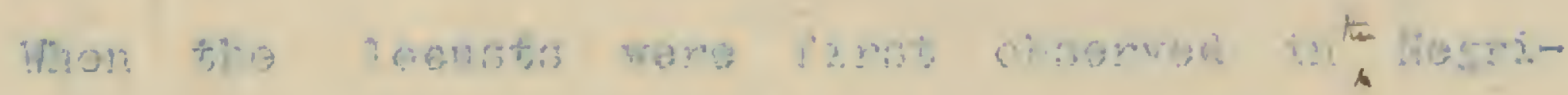

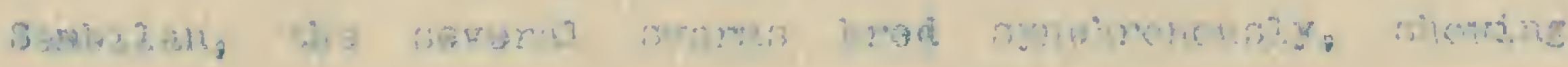

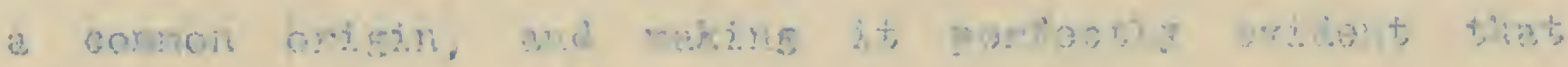

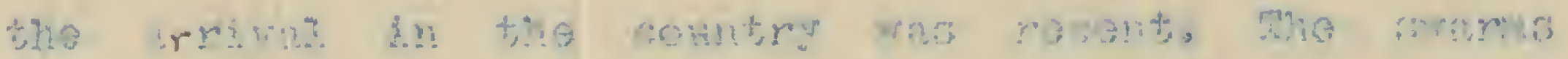

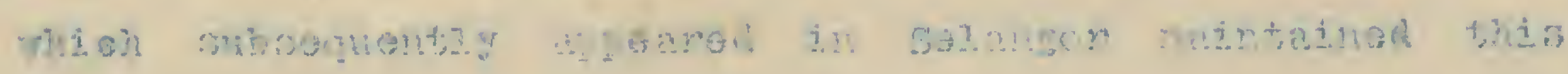

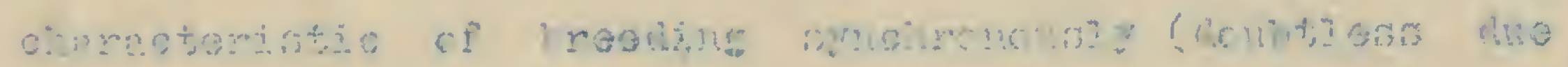

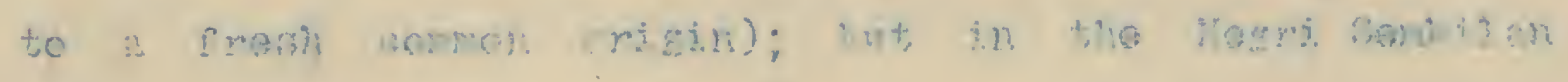

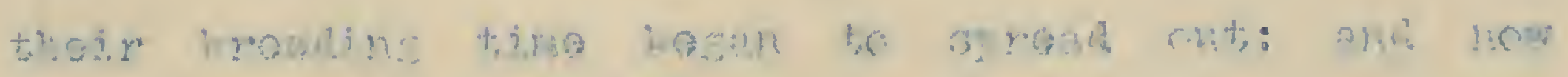

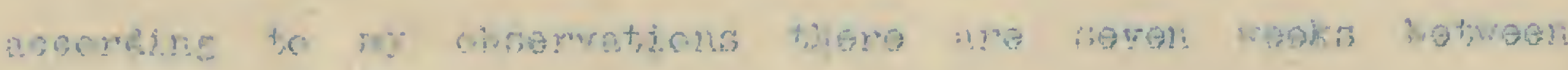

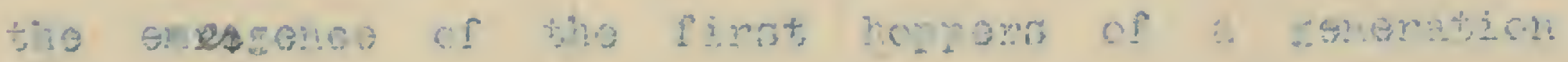

$B 8 \cdot 1 / 4 b$ and the 1406 . 


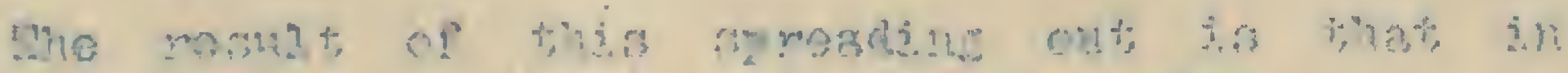
arounming

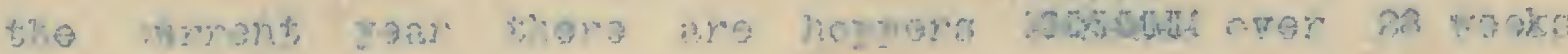

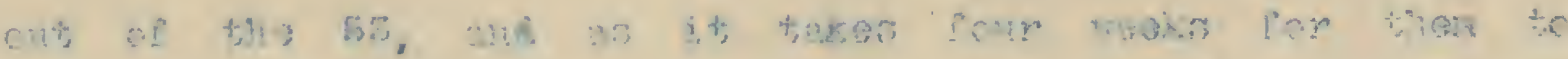

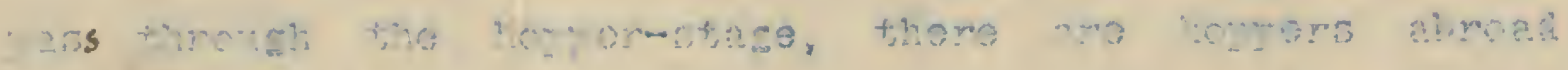

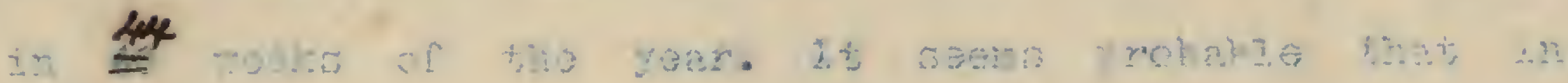

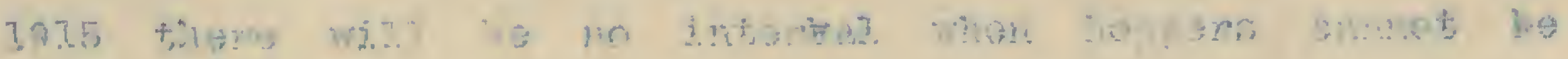
I: $1:: 1$,

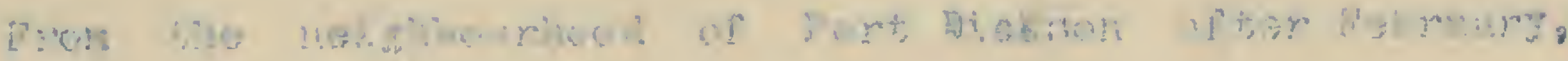

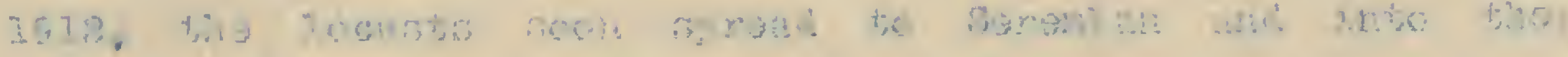

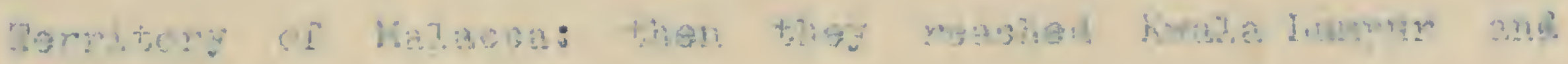

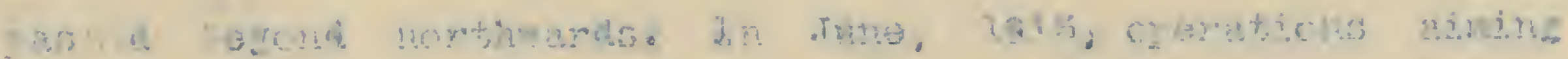

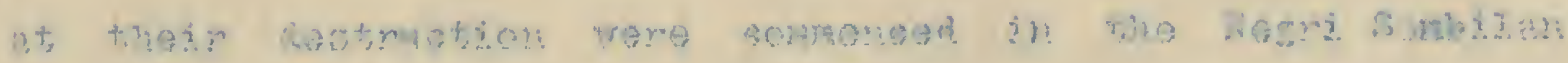

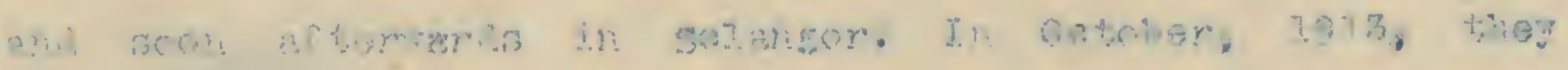

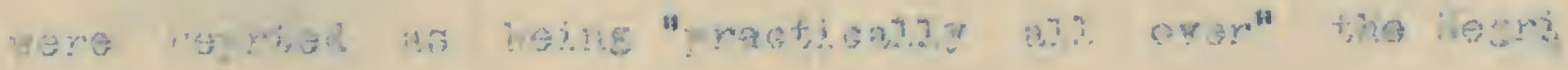

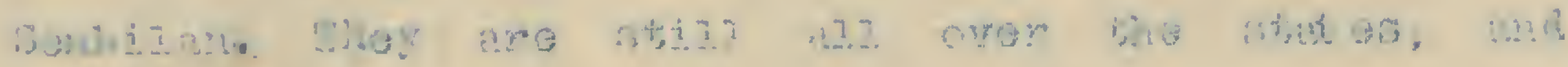

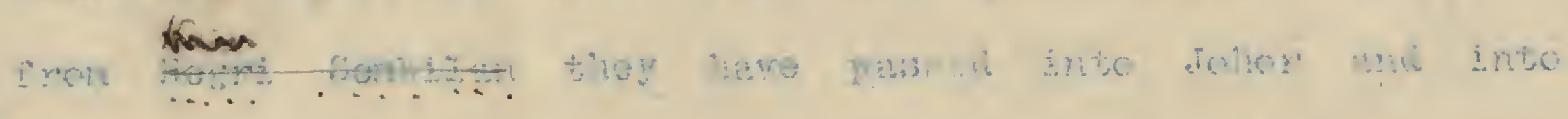
Ita is as.

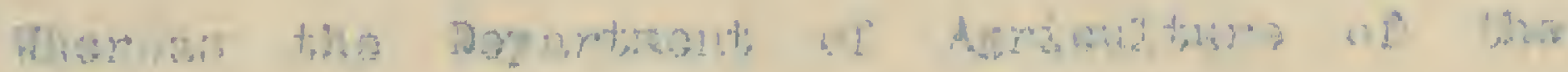

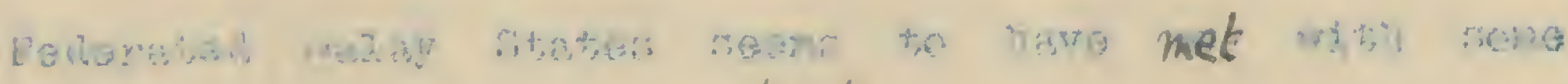

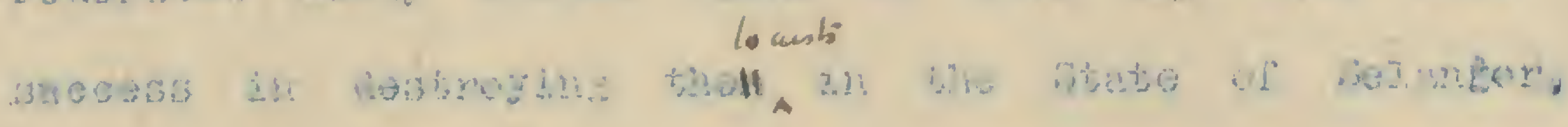

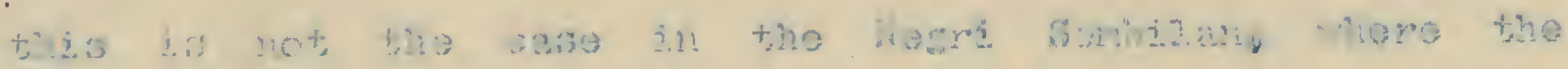

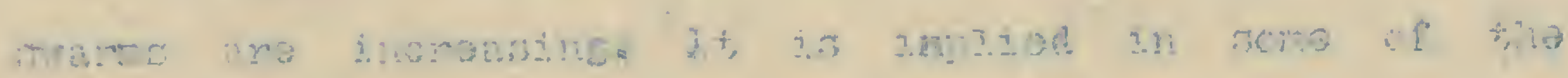

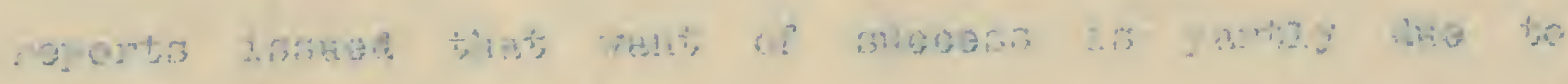

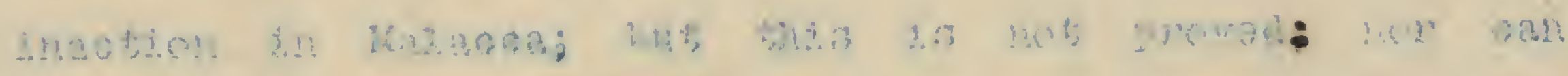

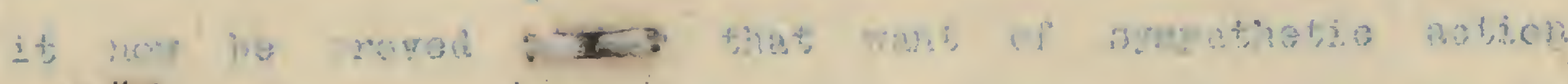
ratter

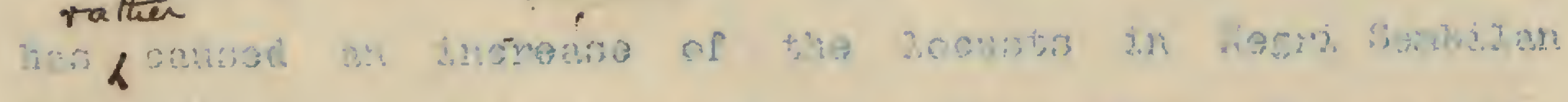

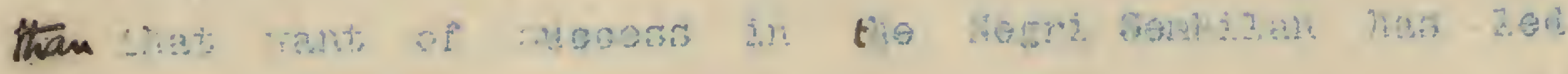

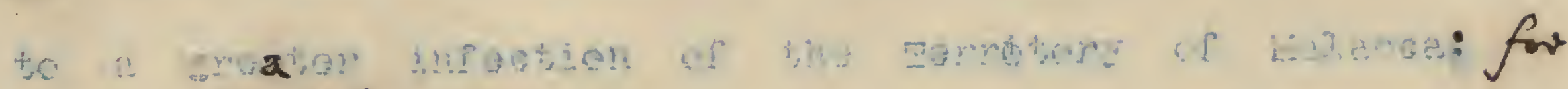
Wi:t, chicty happenim now

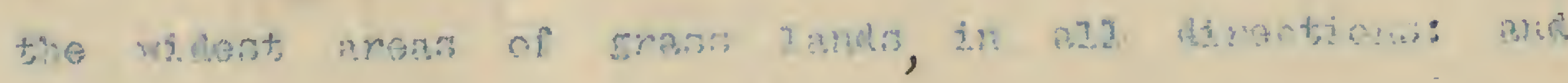


- the seare of the longen penations.

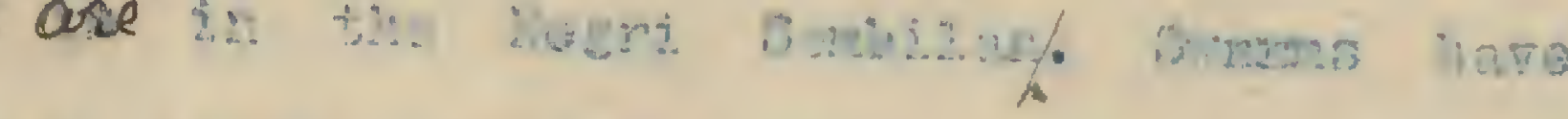

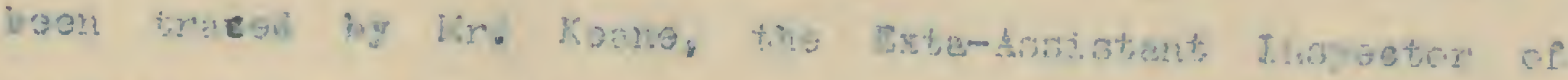

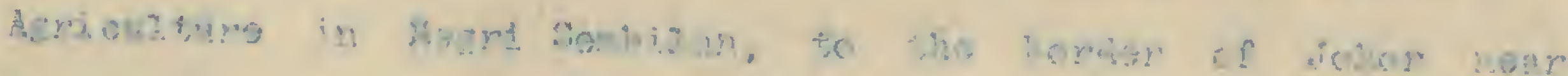

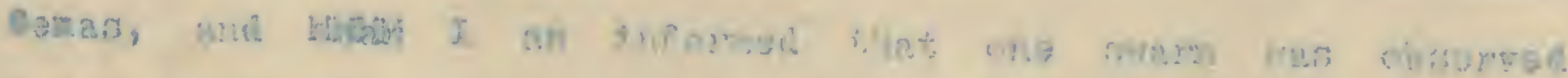

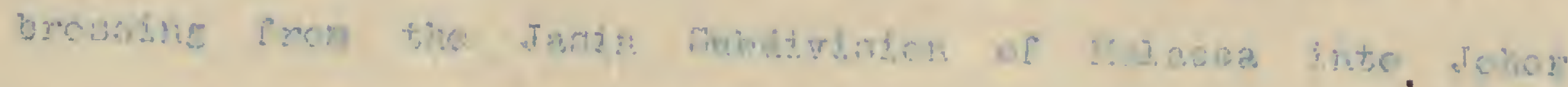

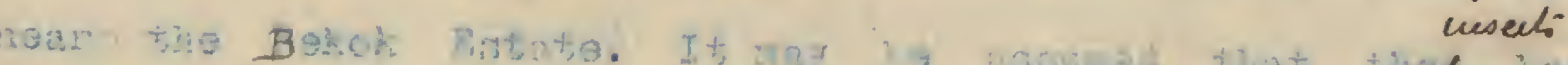
be

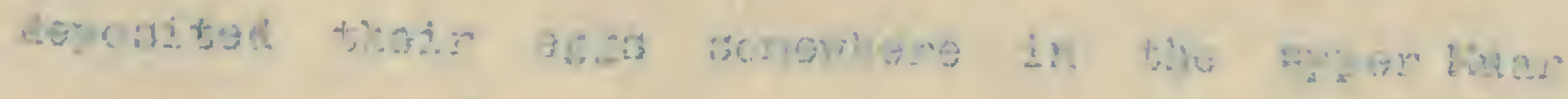

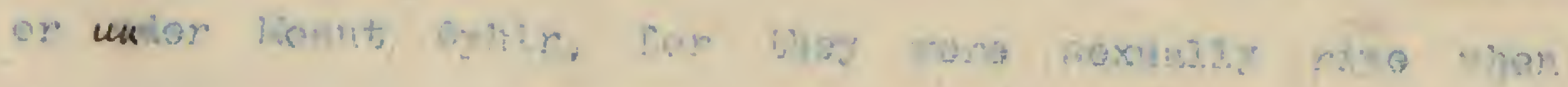

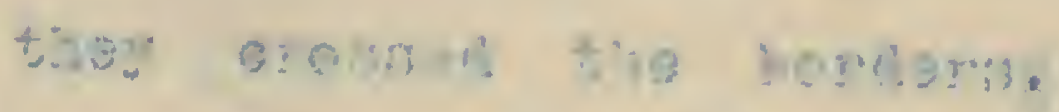

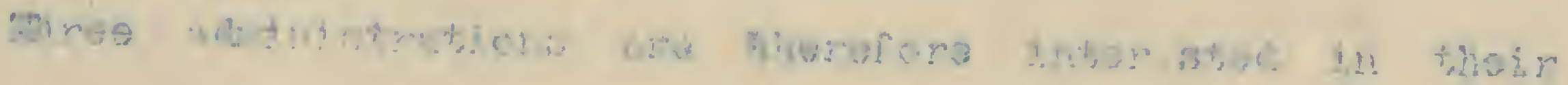

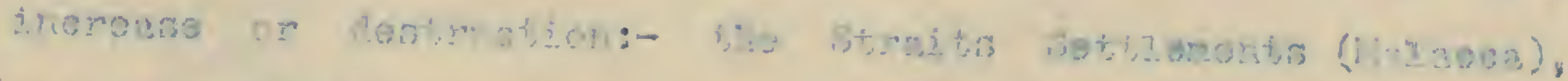

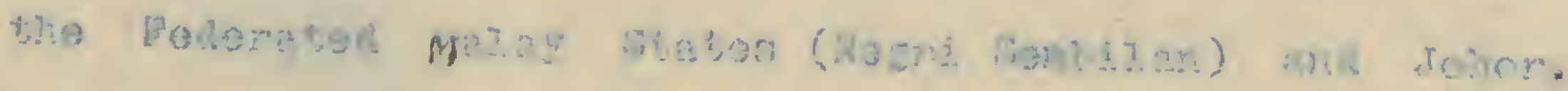

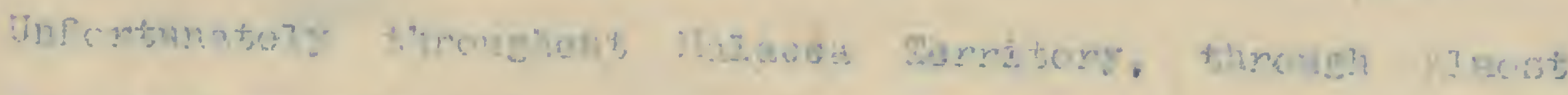

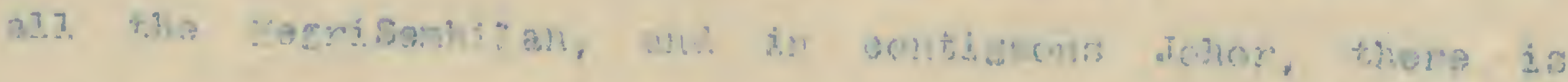

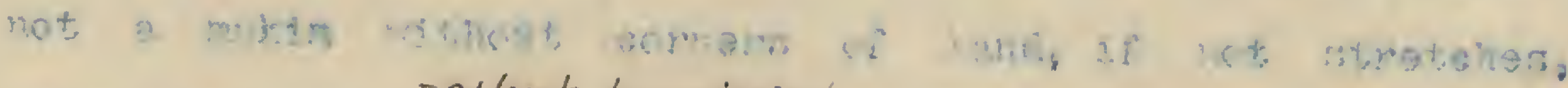

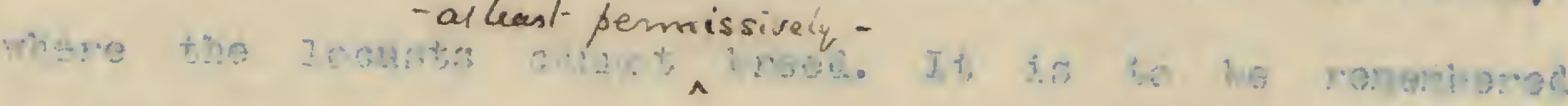

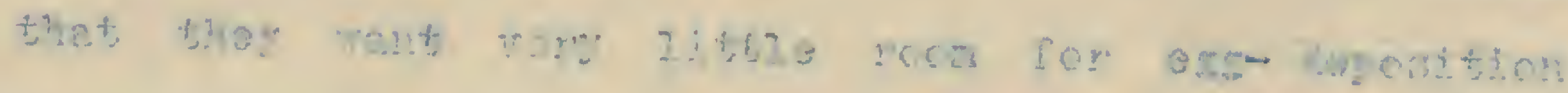

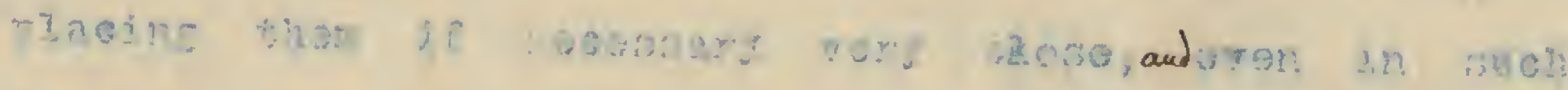

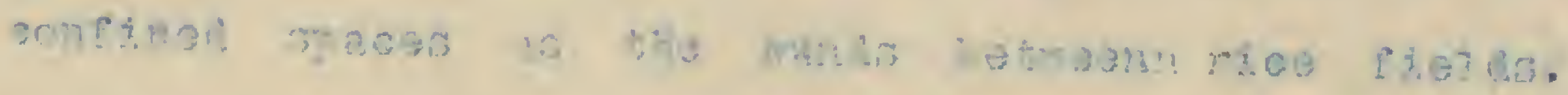

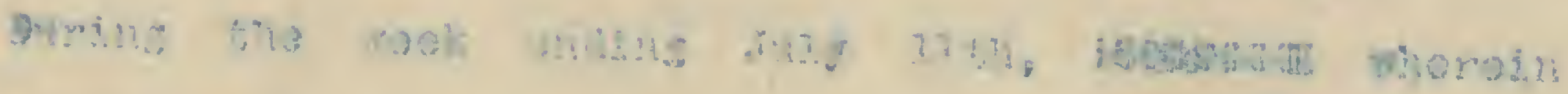

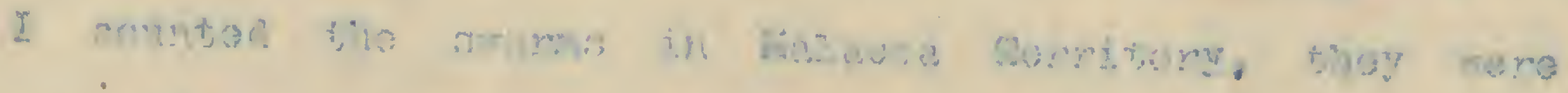

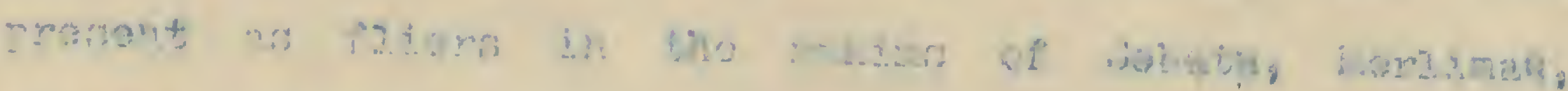

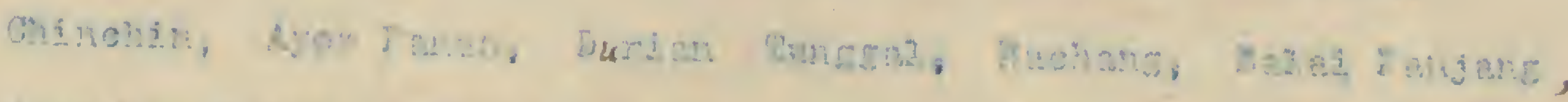

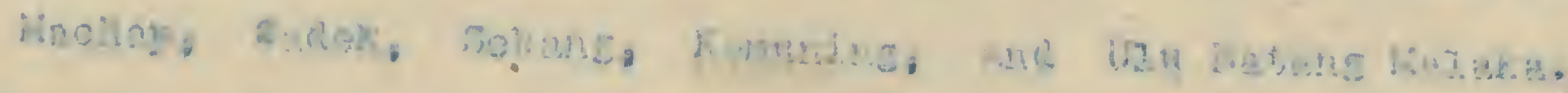

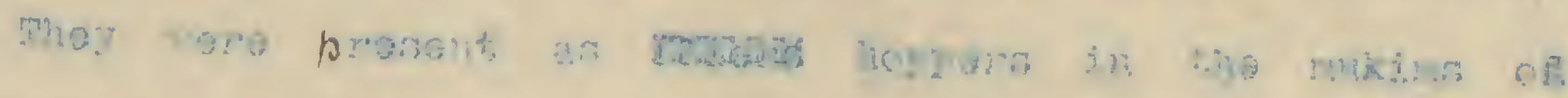

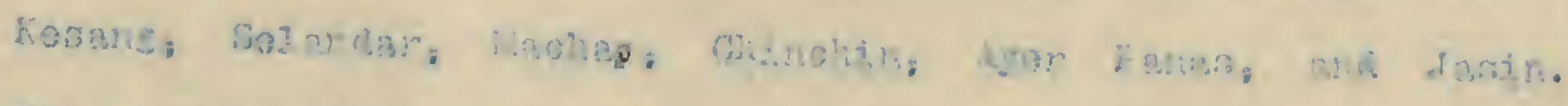

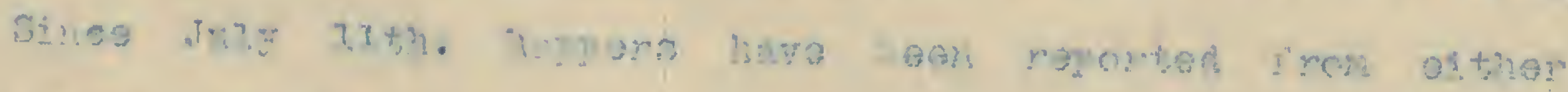

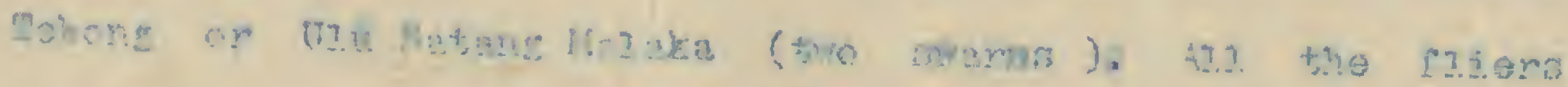

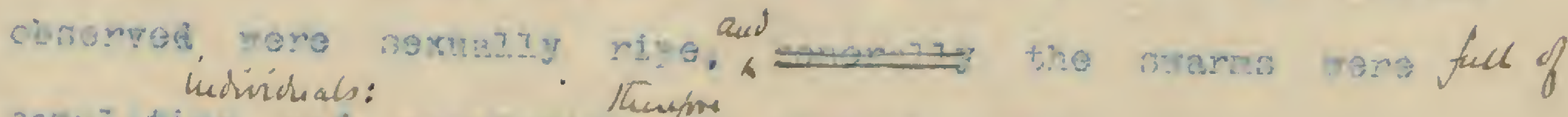
octounding 


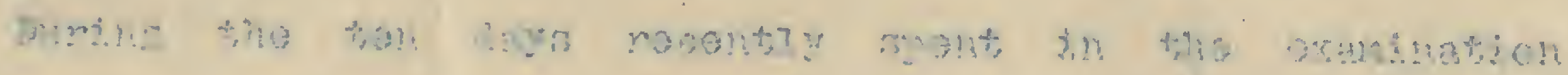

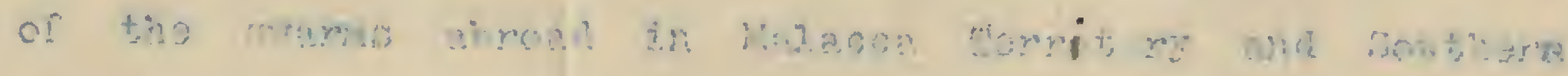

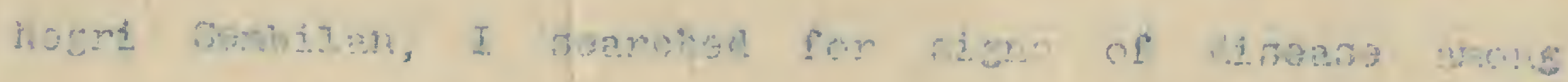

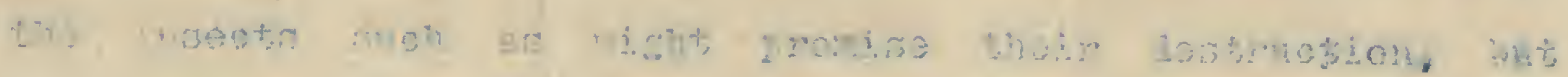

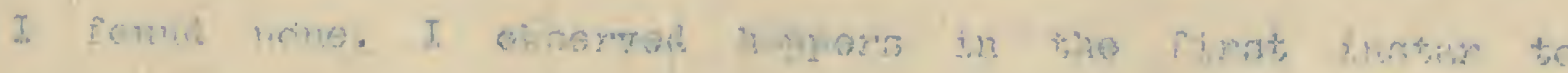

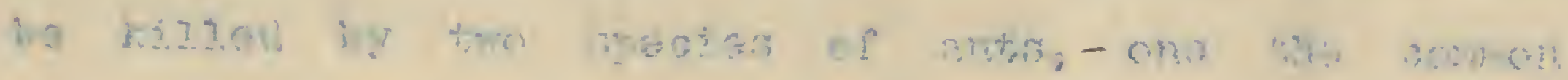

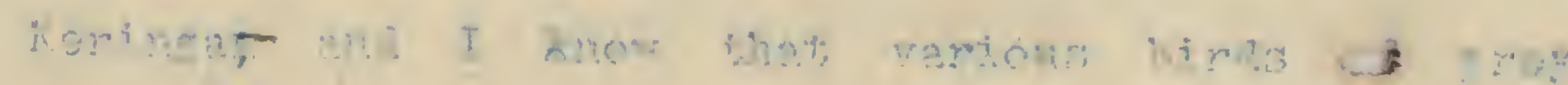

st

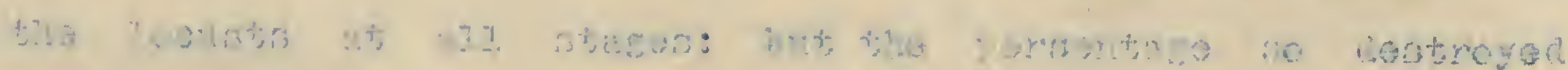

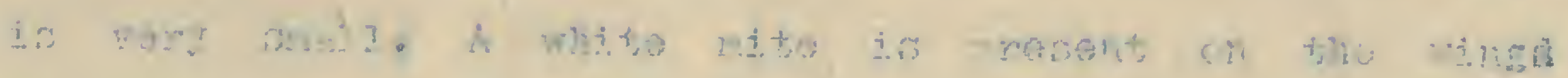

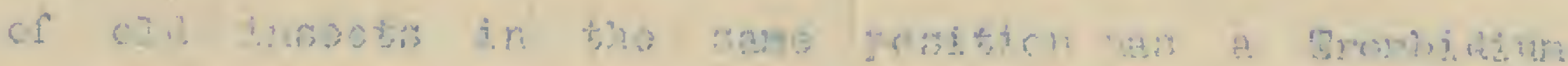

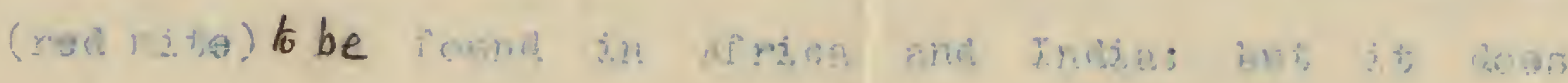

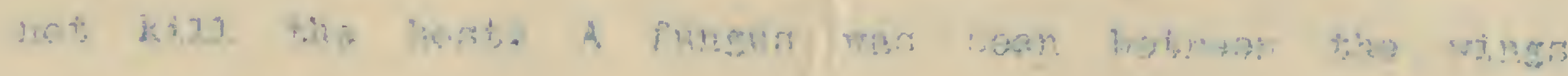

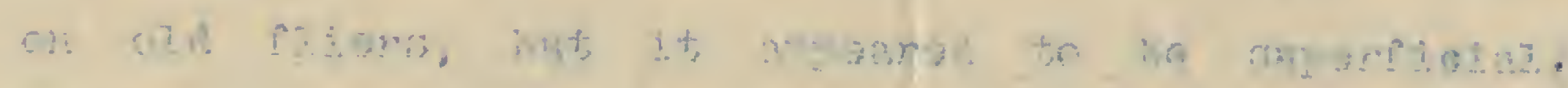

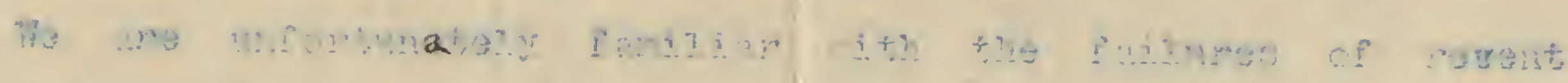

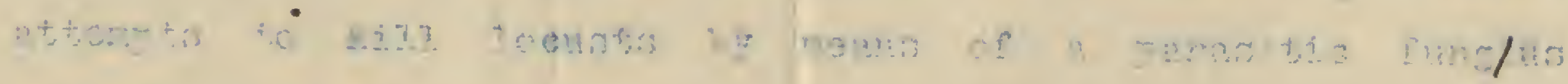
and of n tabtamins.

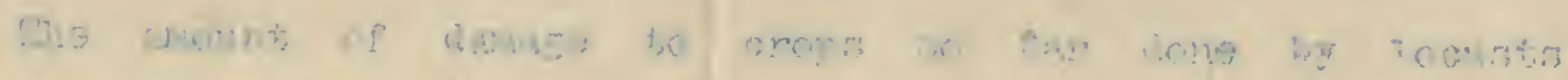

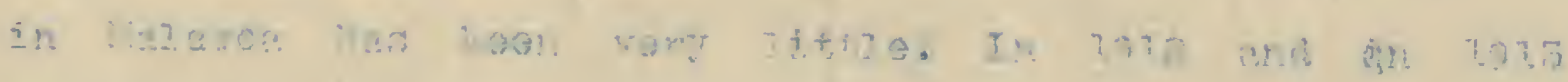

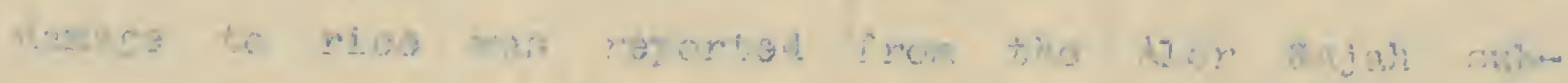

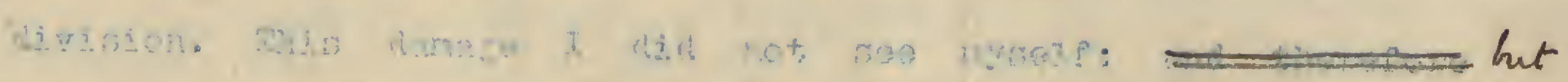

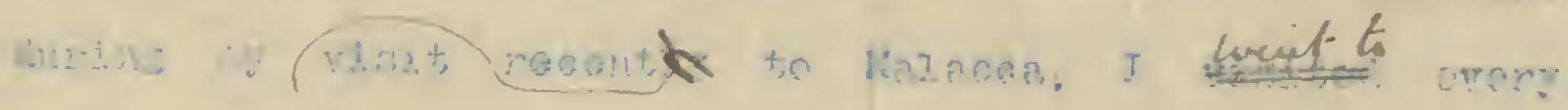

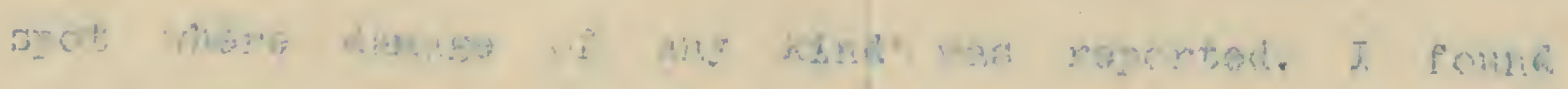

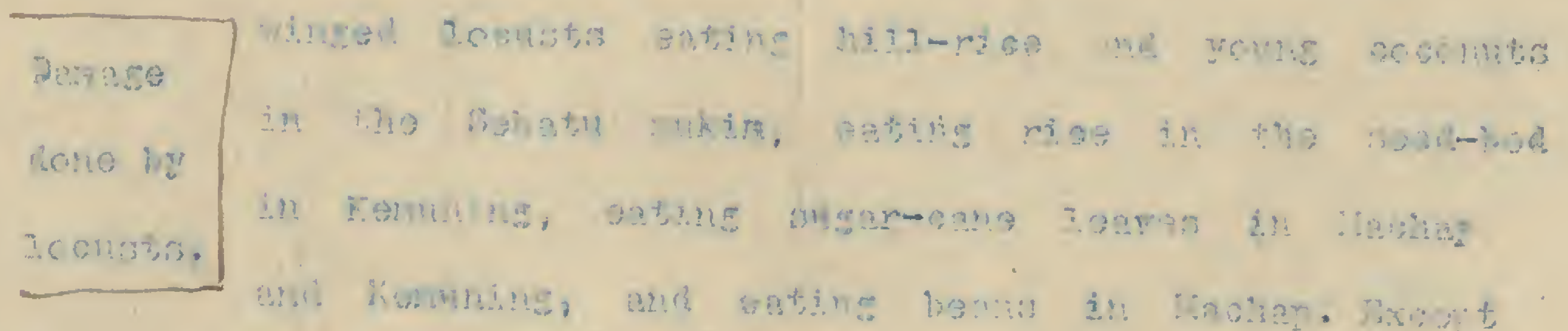

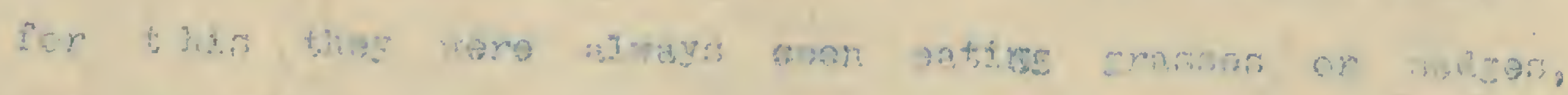

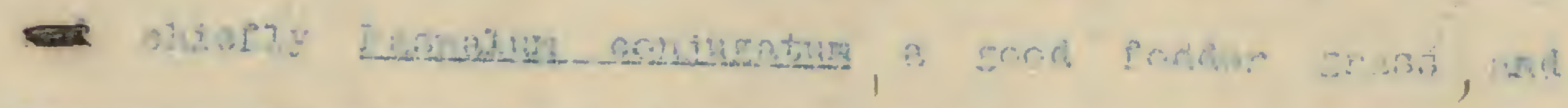

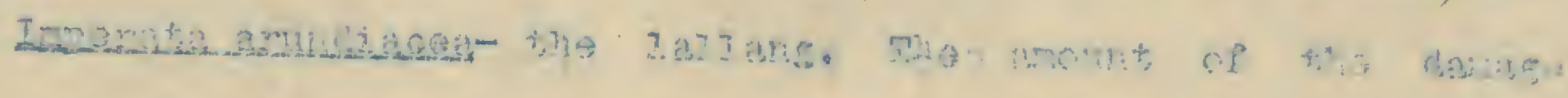

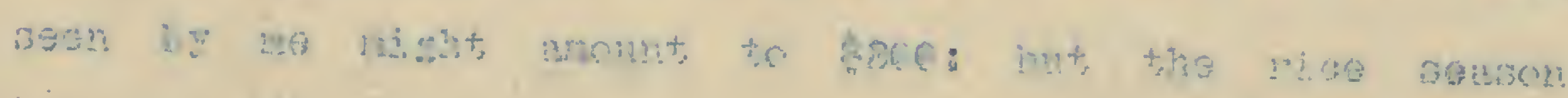
$B 8 \cdot 1 / 59$ 


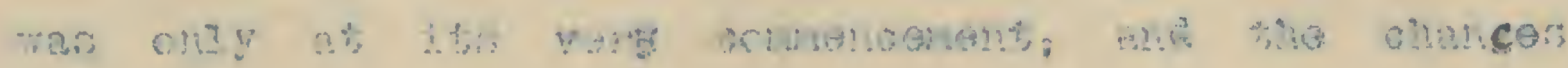

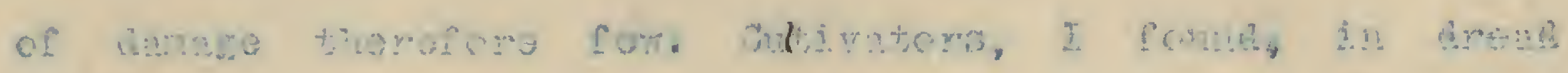

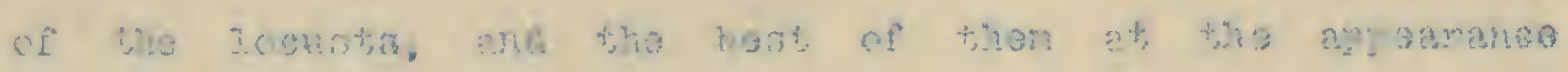

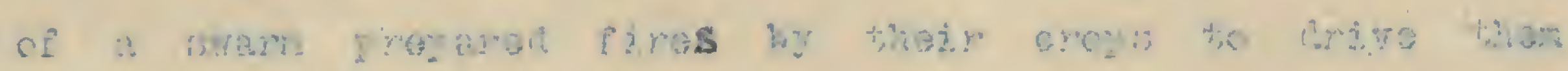

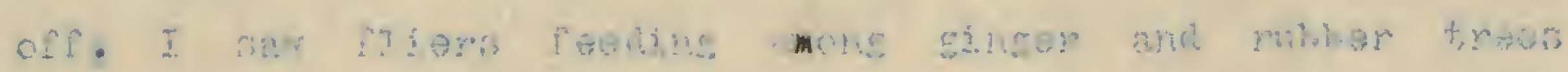

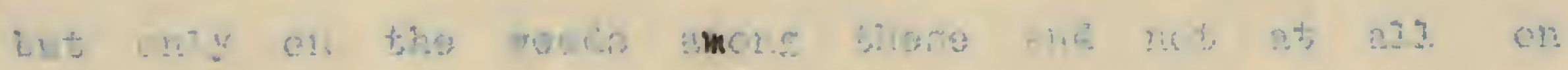

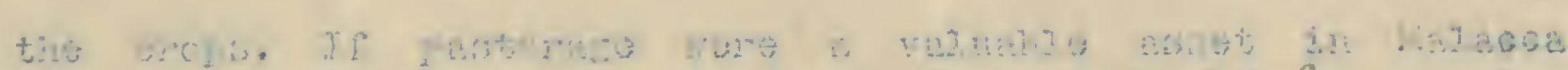

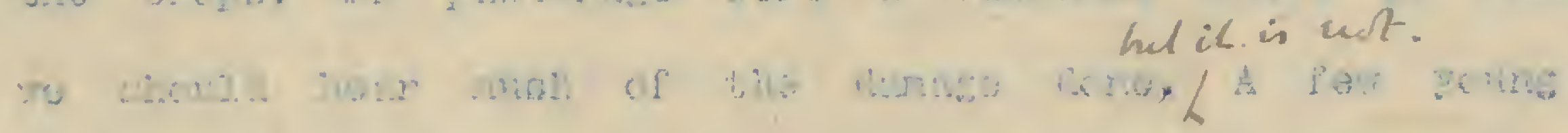

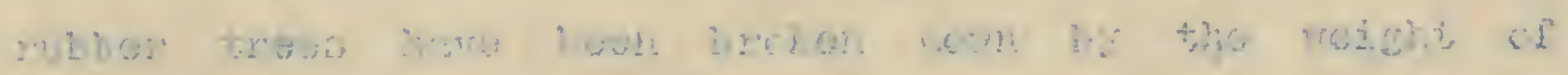

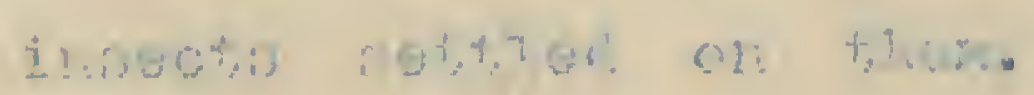

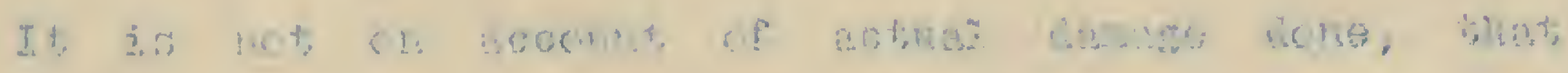

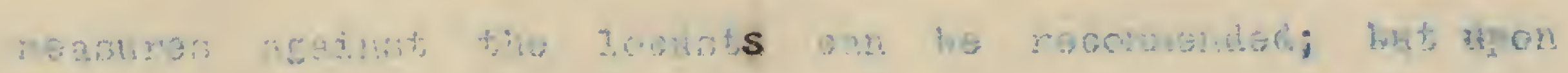

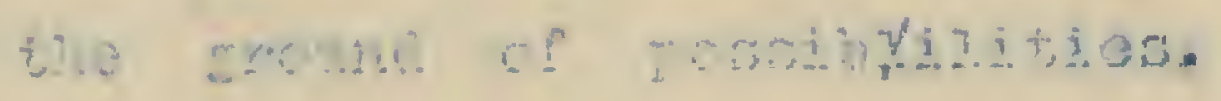

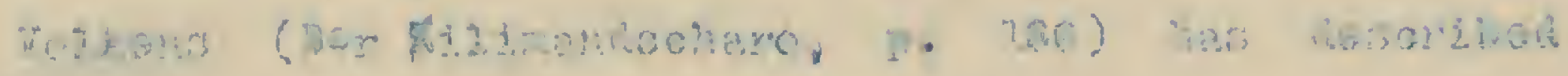

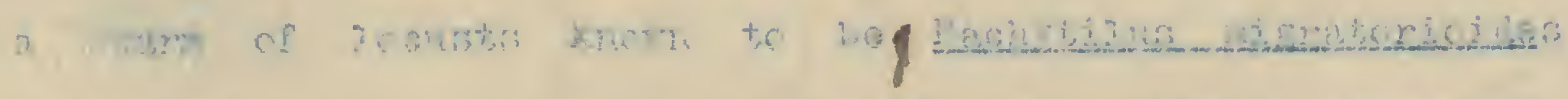

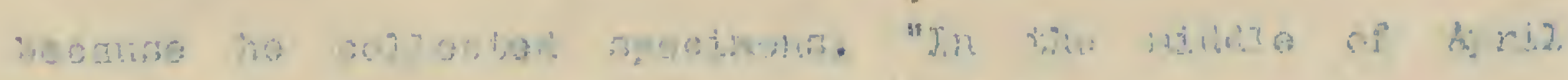

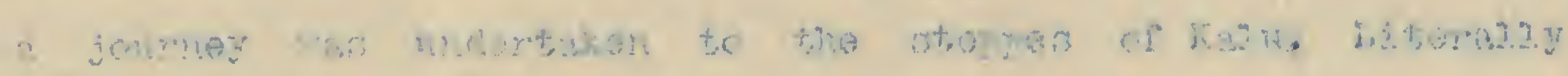

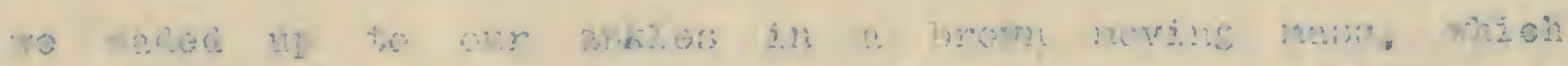

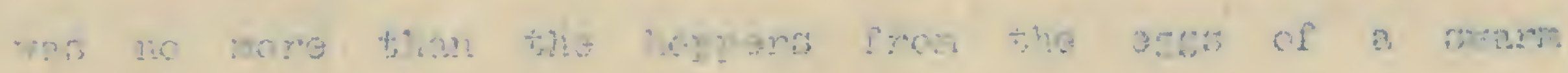

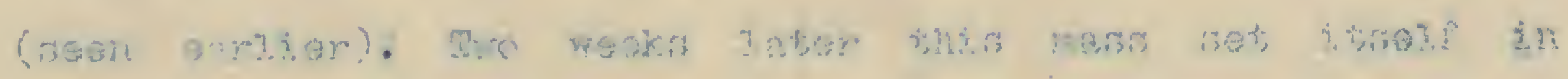

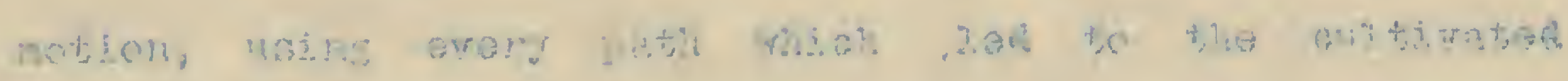

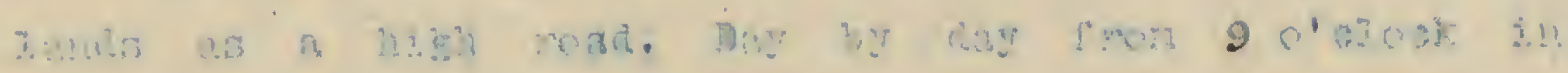

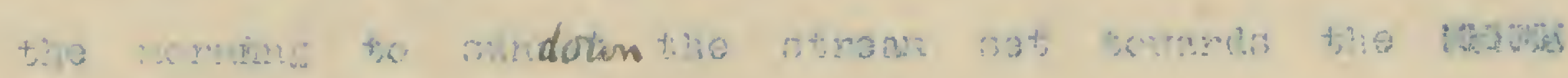

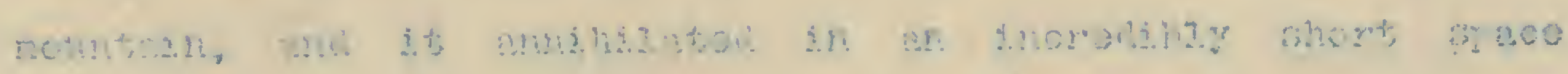

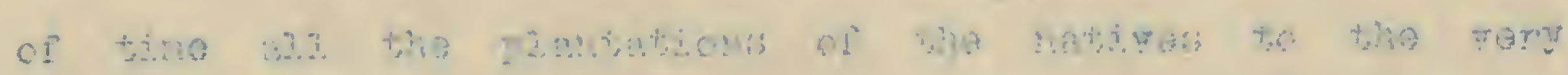

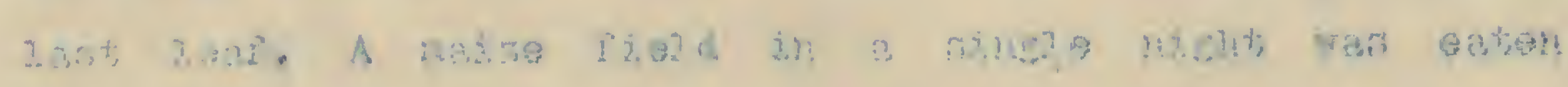

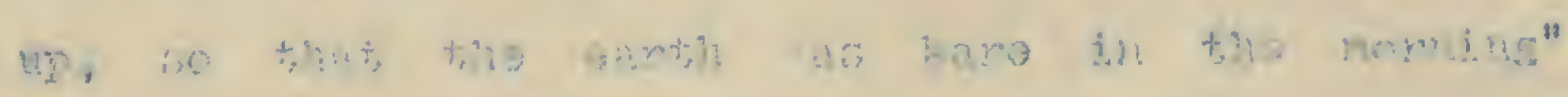

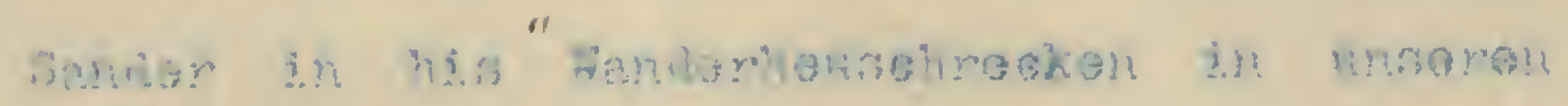

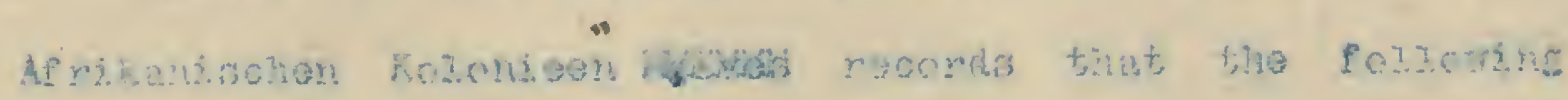

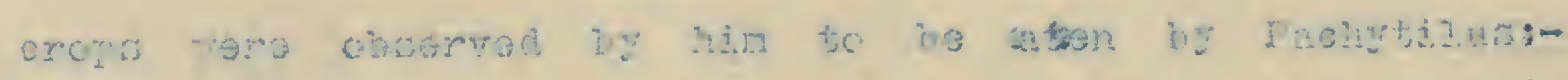

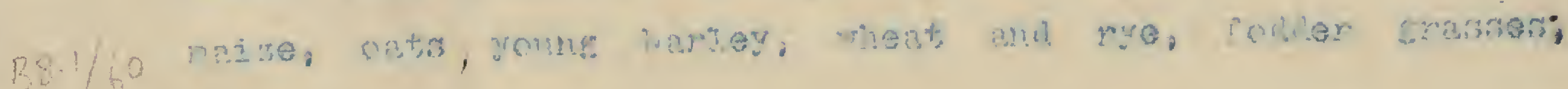




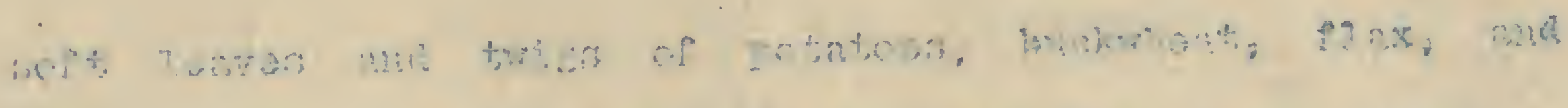

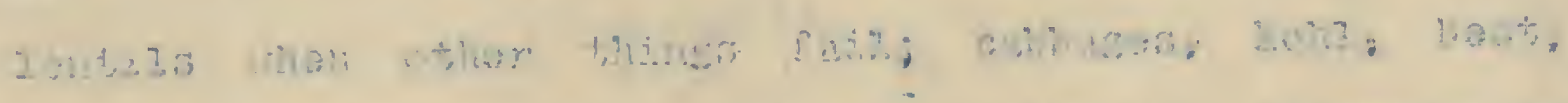

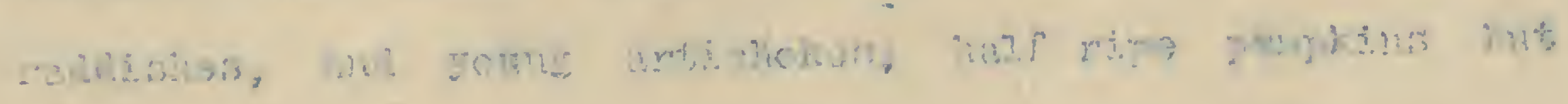

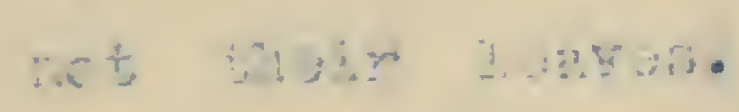

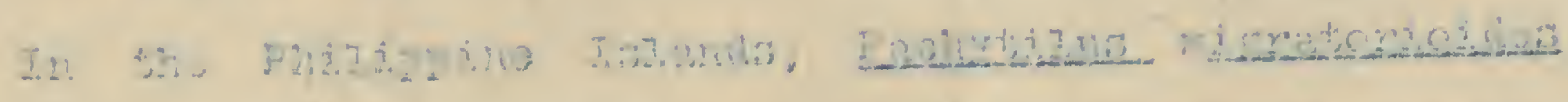

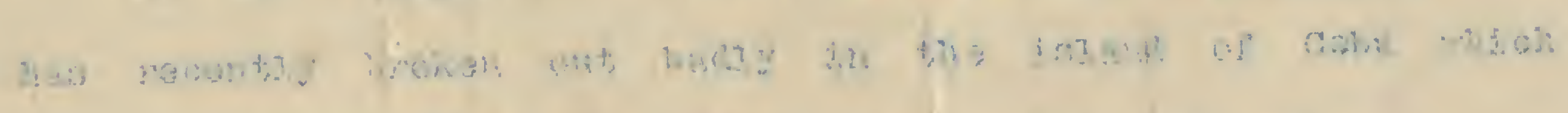

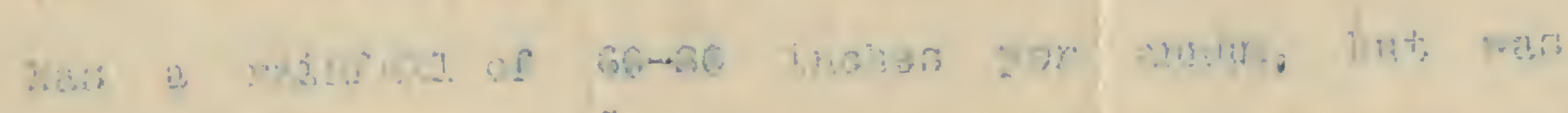

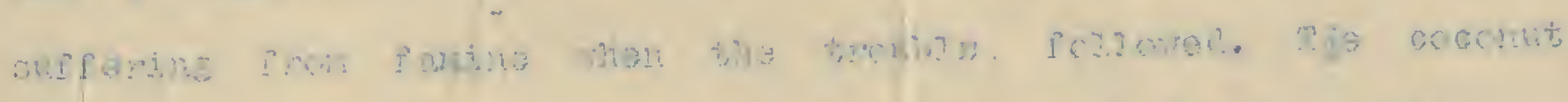

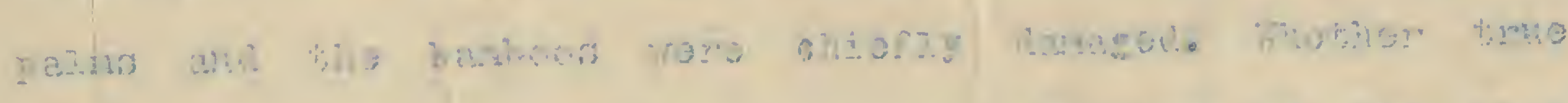

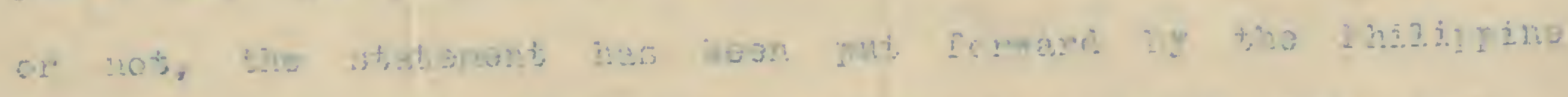

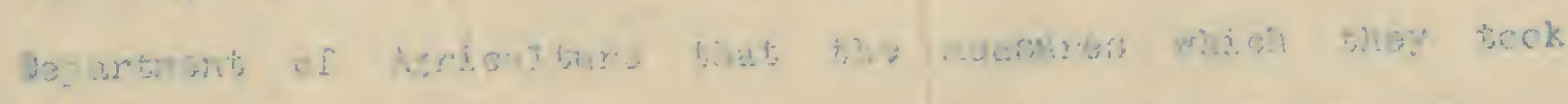

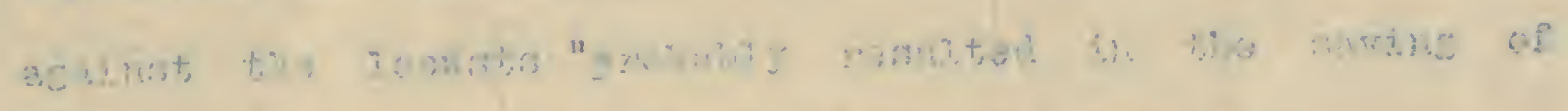

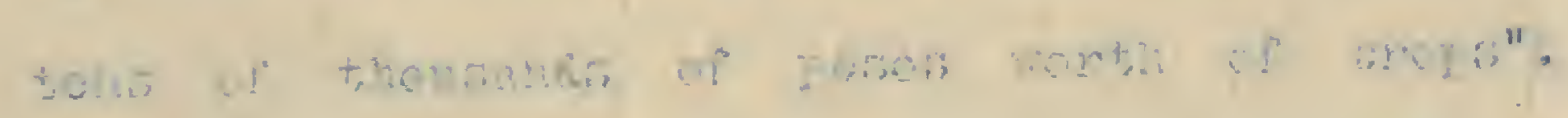

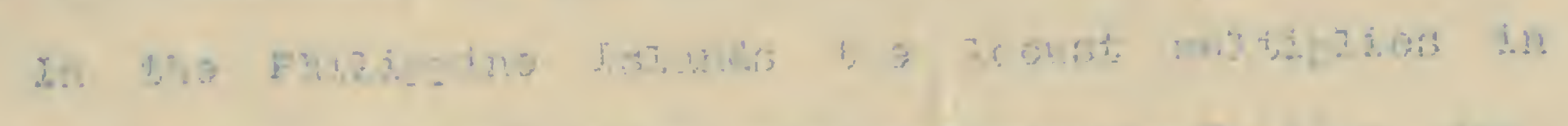

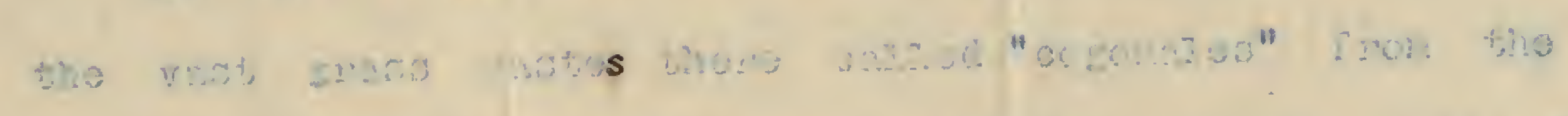

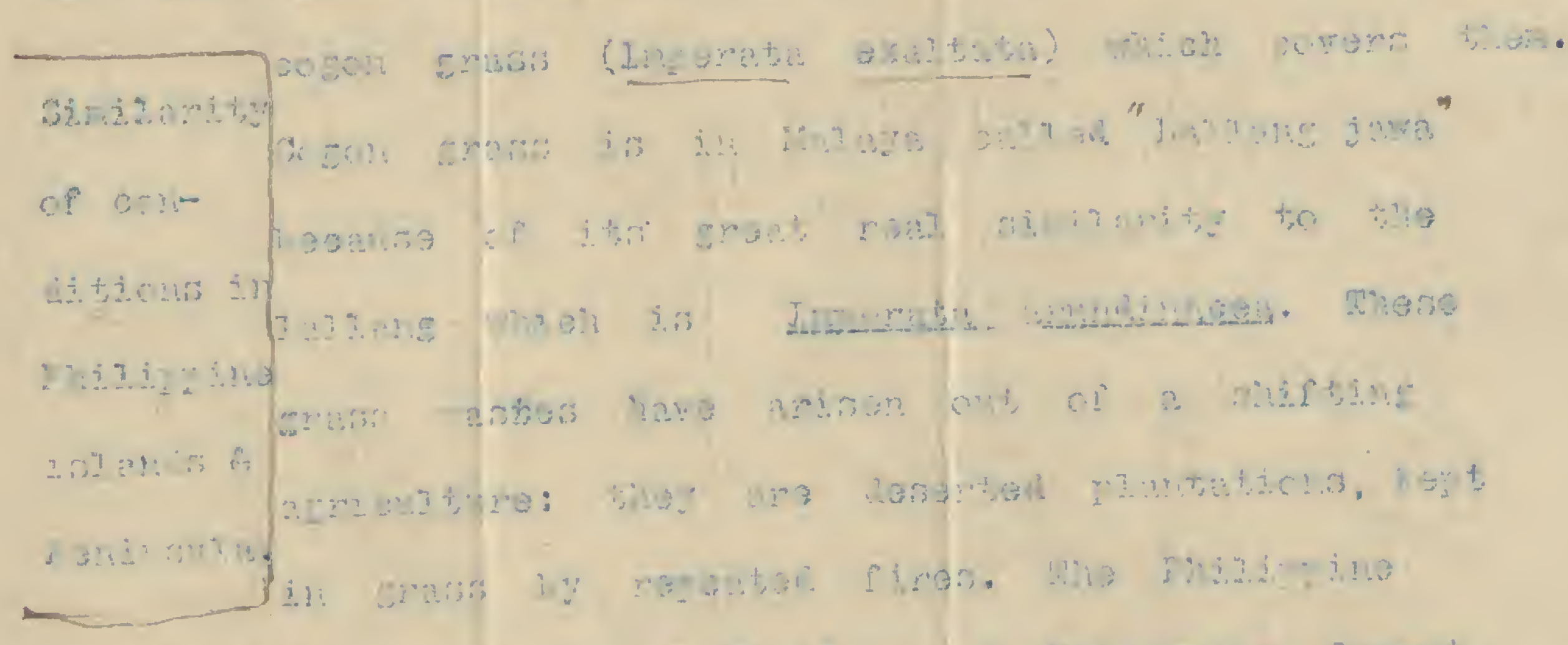

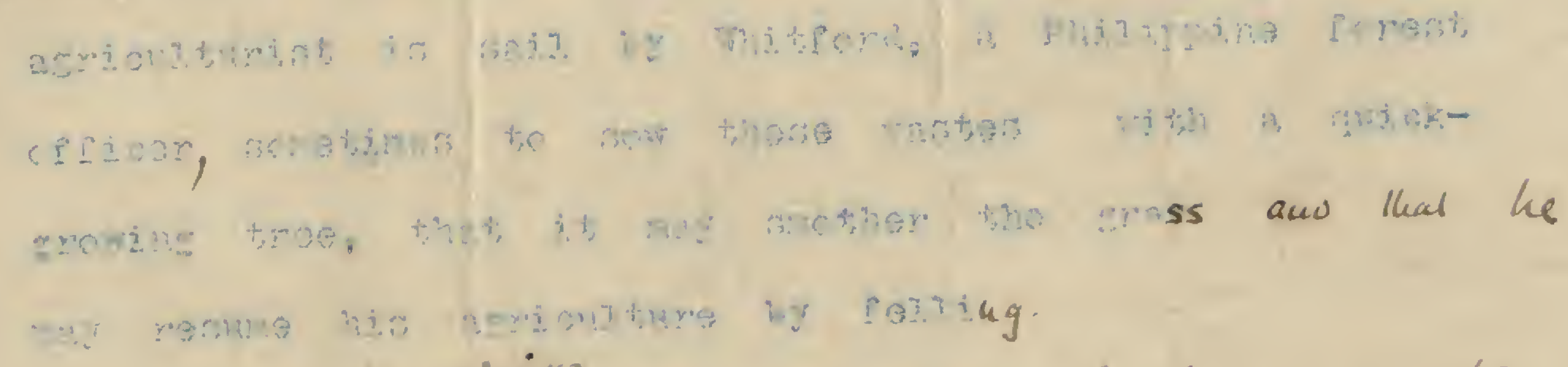

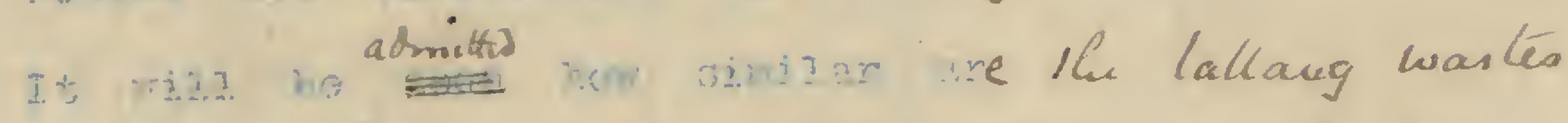

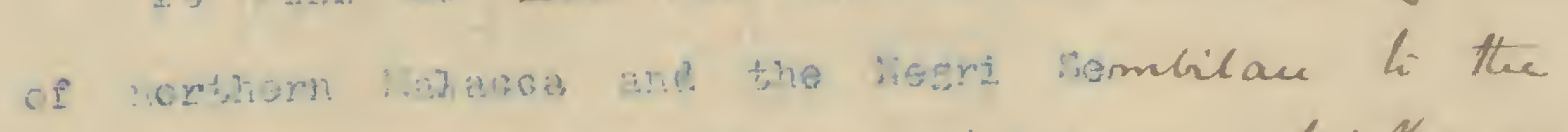

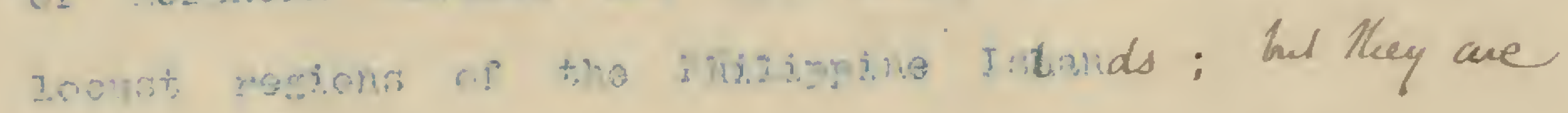

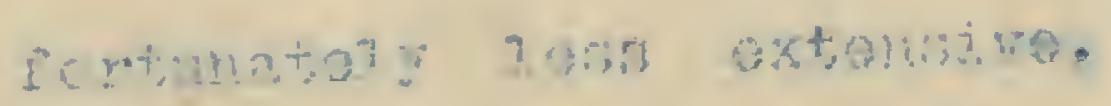




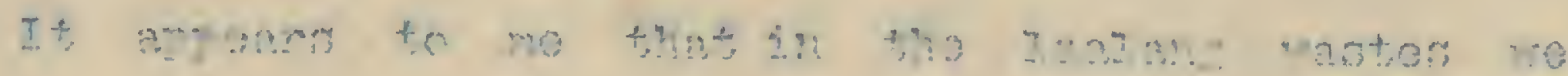

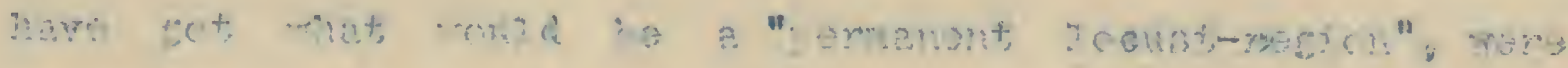

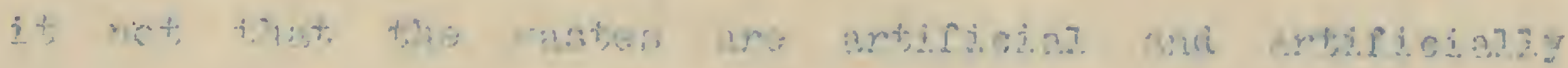

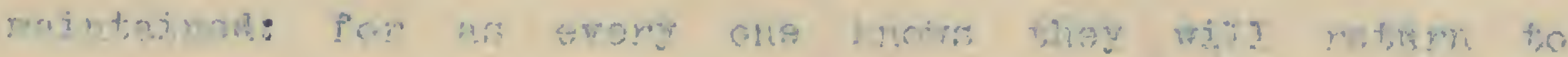

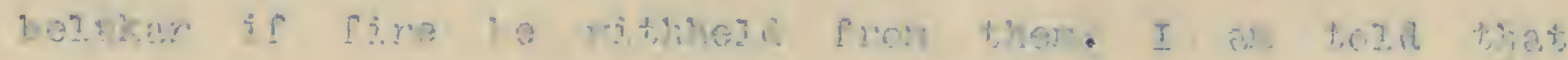

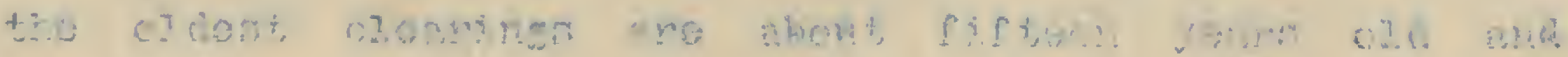

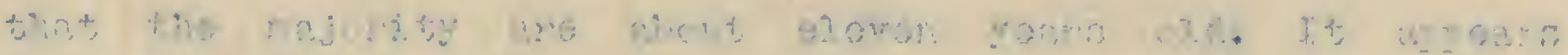

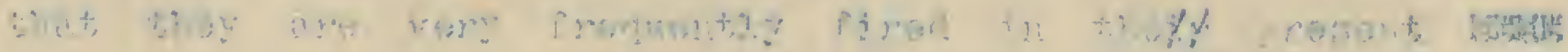

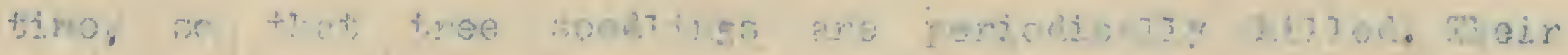

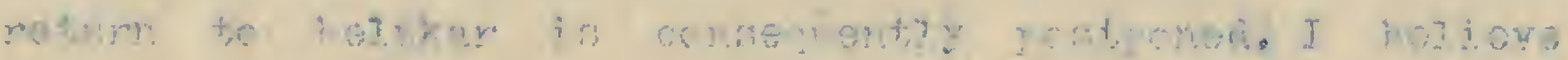

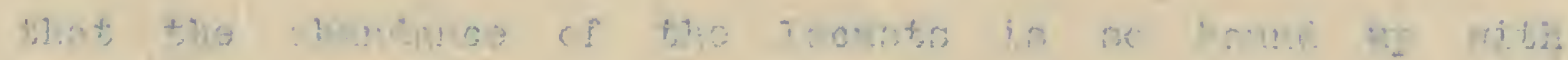

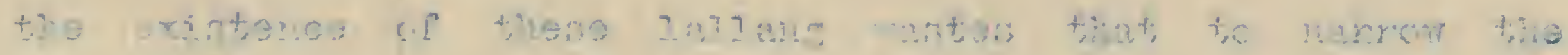

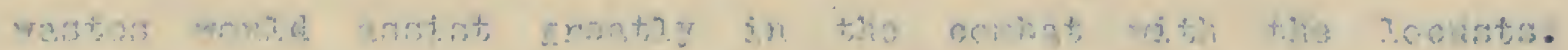

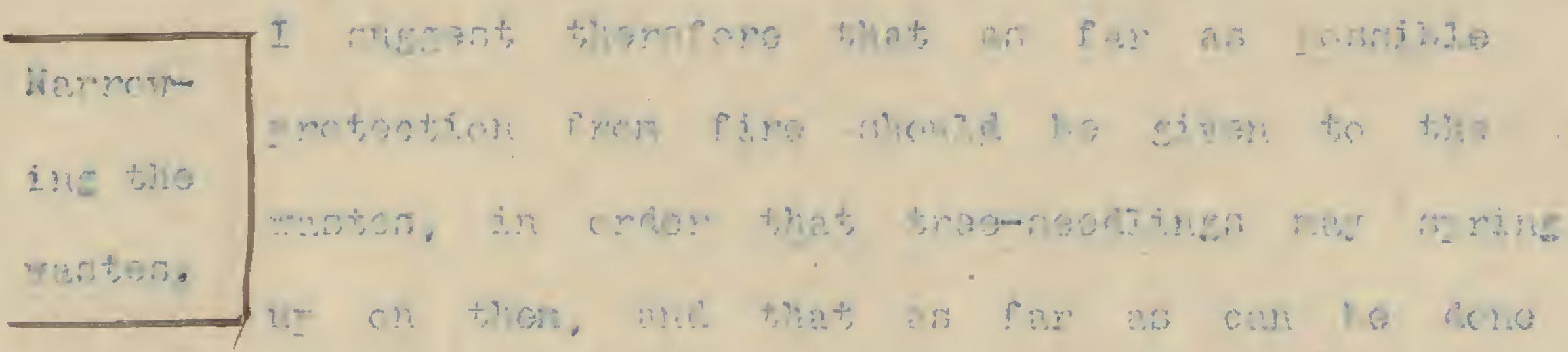

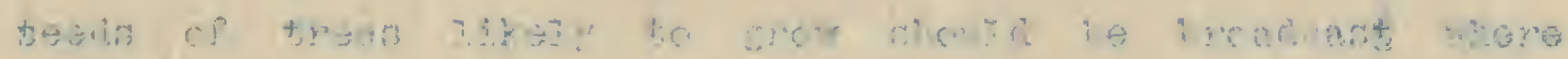

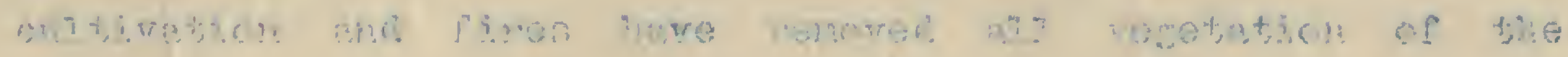

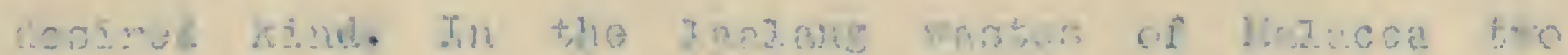

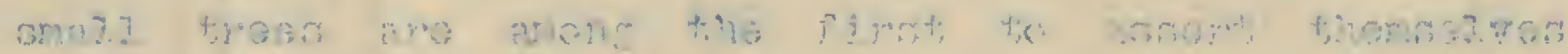

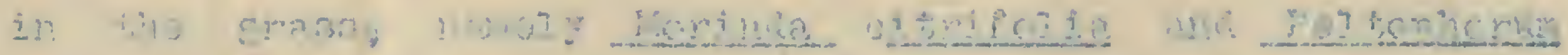

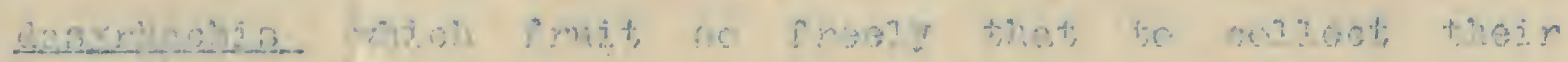

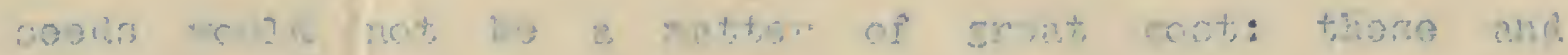

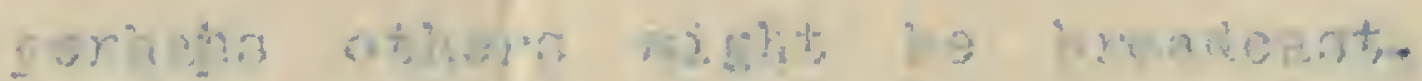

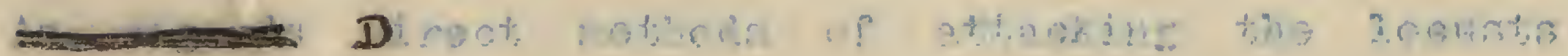

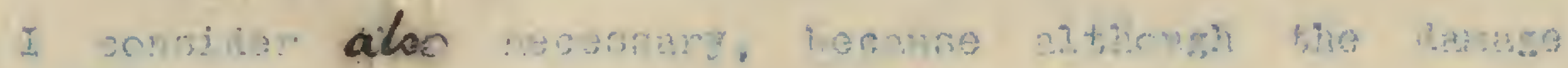

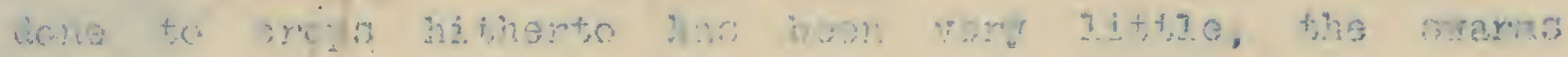

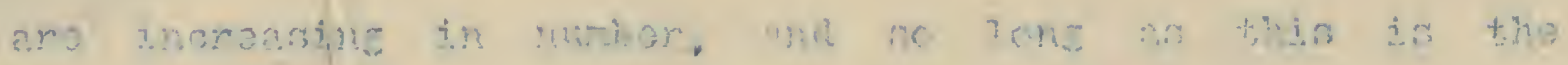

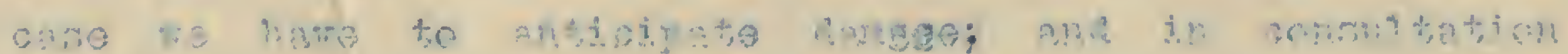
62

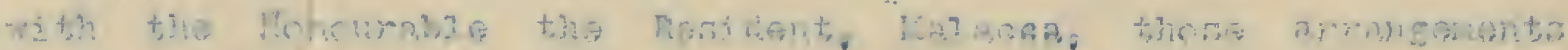




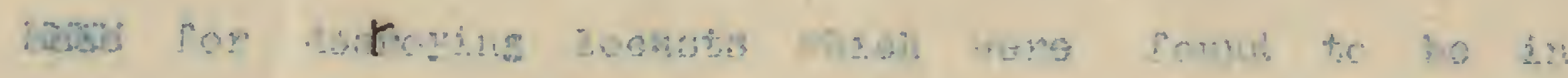

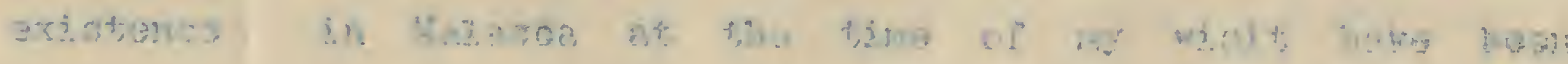

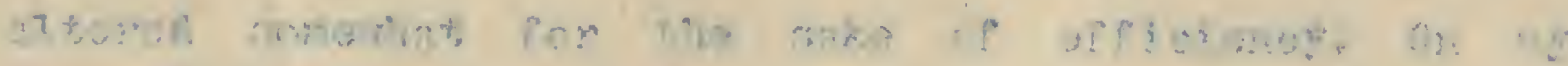

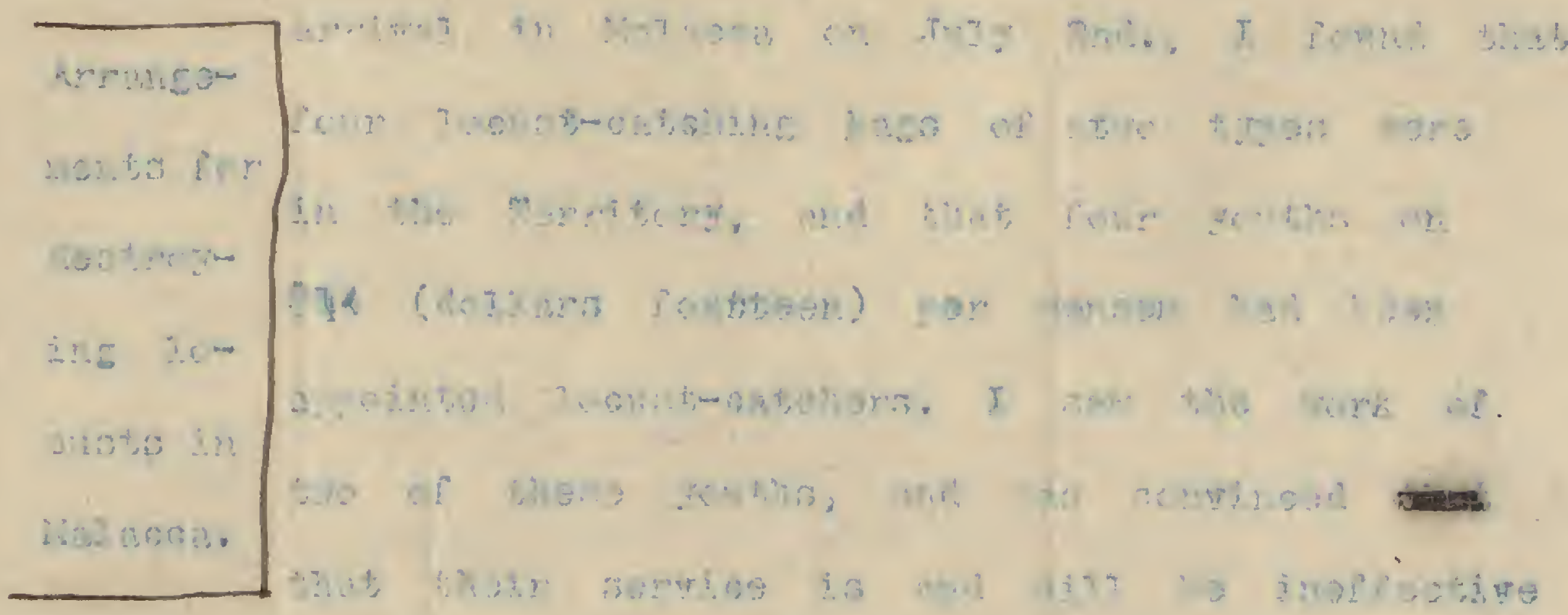

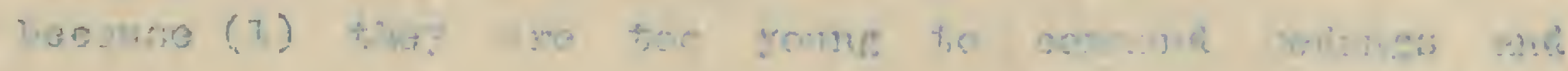

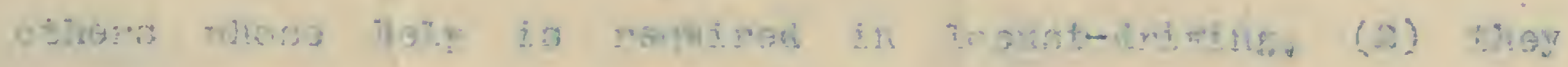
bow.

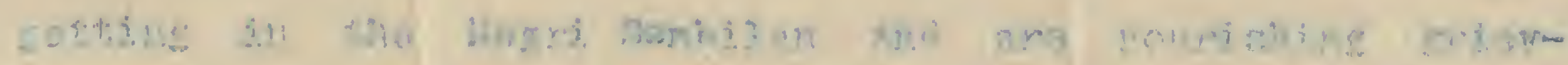

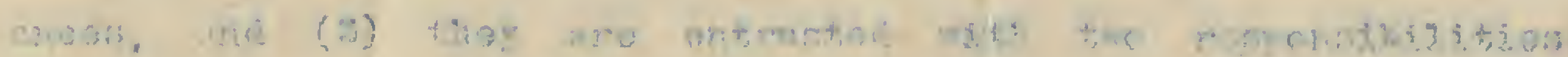

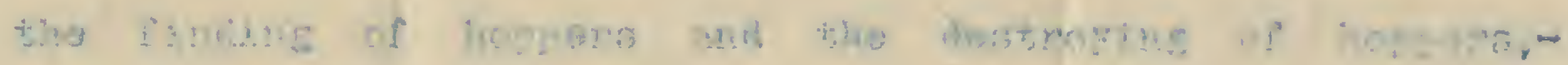

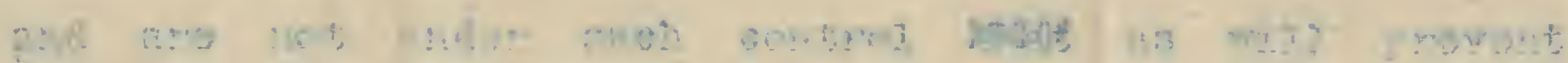

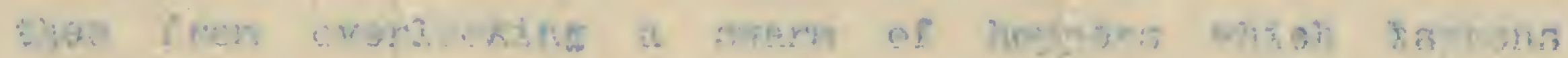

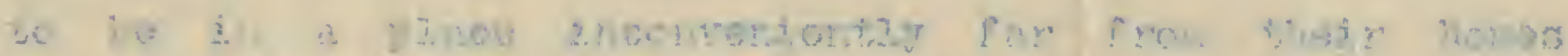

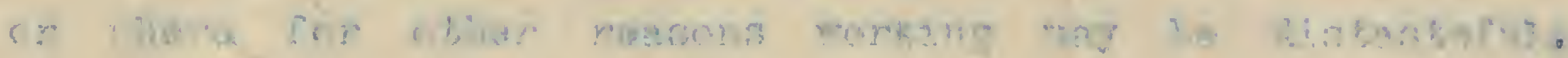

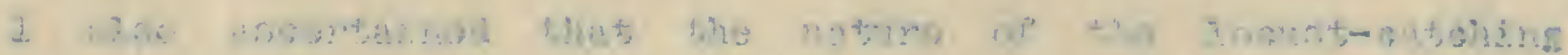

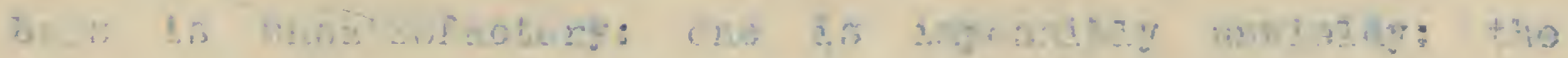

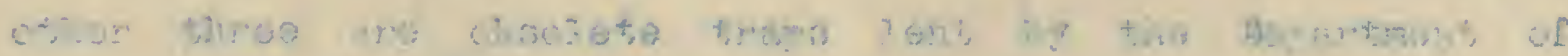

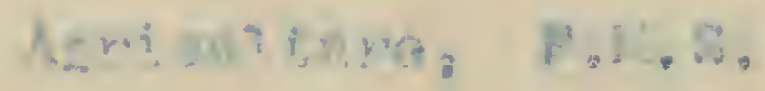

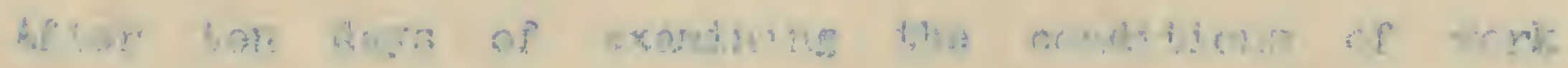

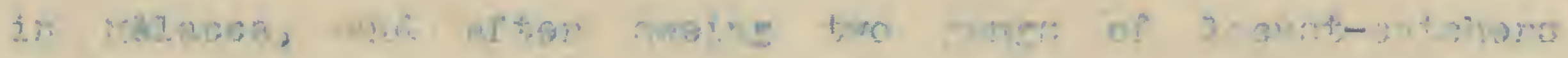

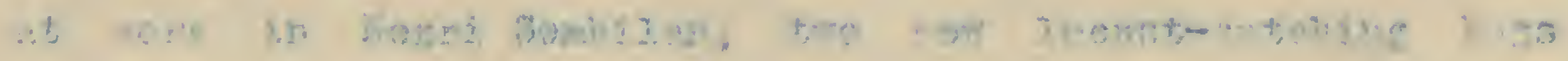

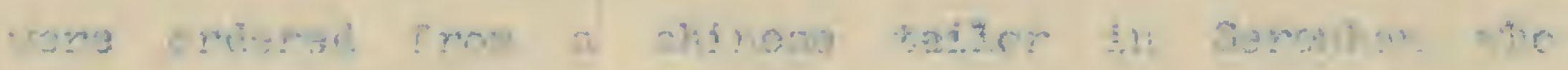

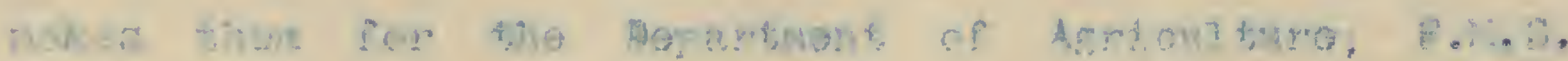

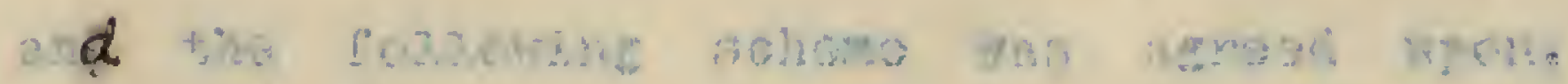




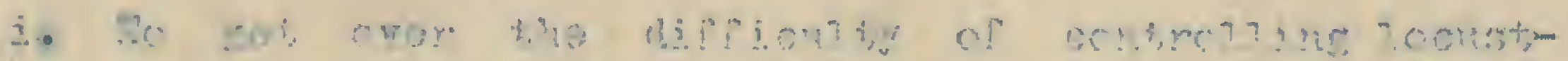

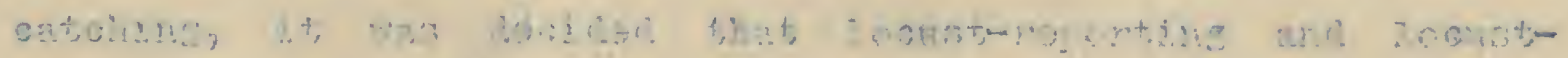

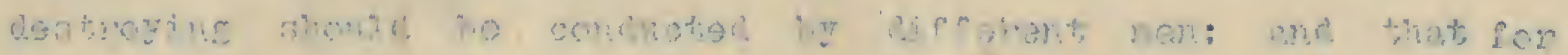

\section{five rogyen the samp}

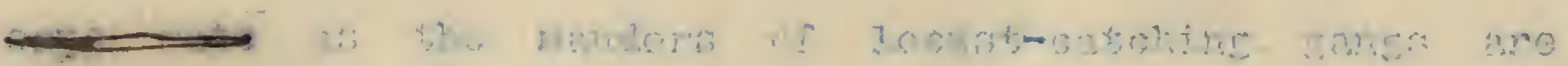

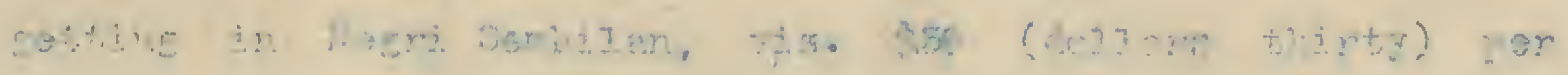

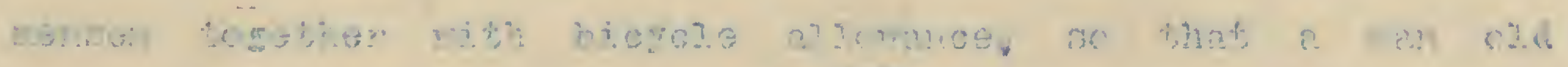

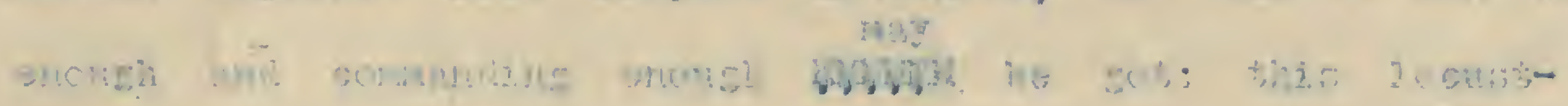

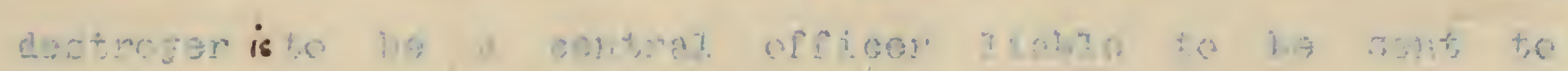

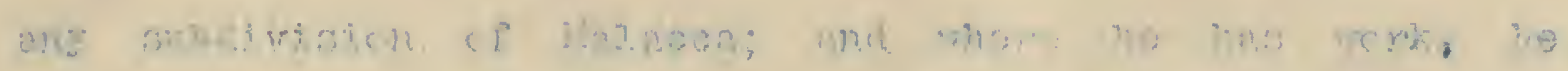

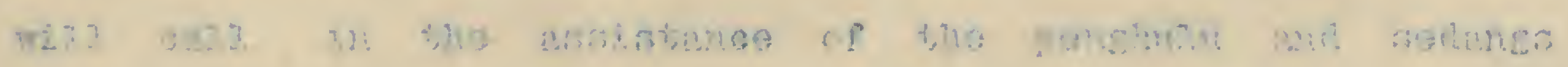

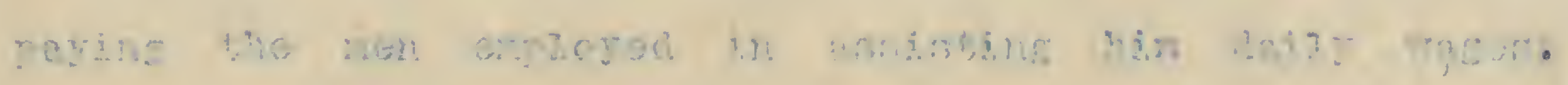

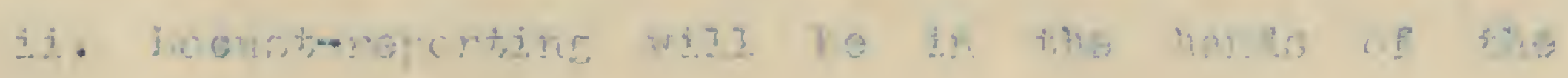

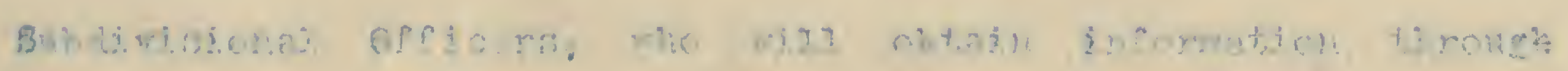

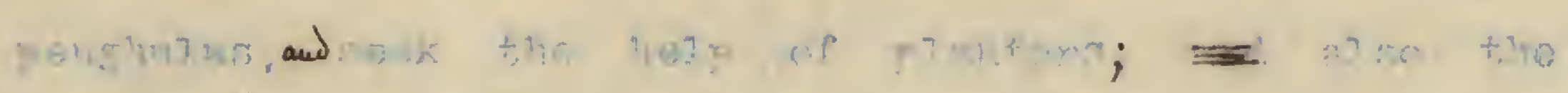

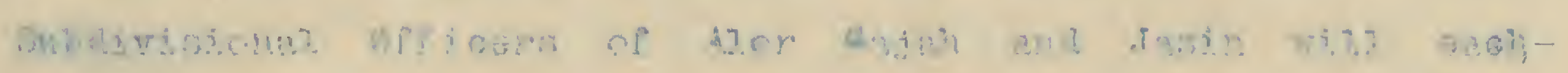

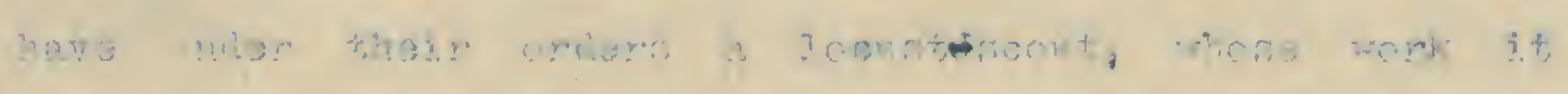

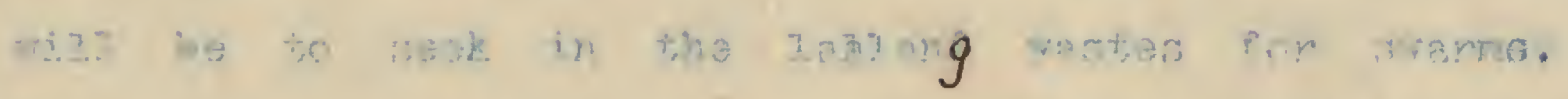

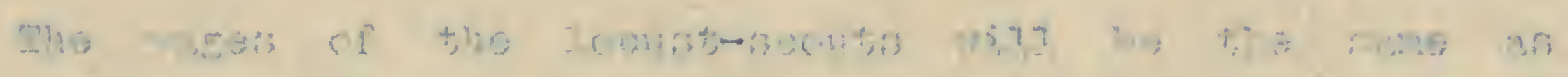

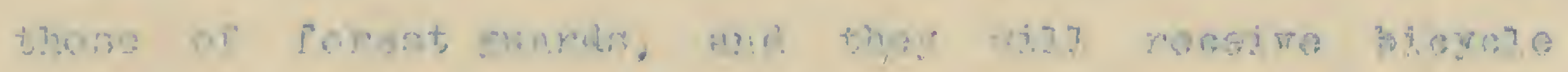

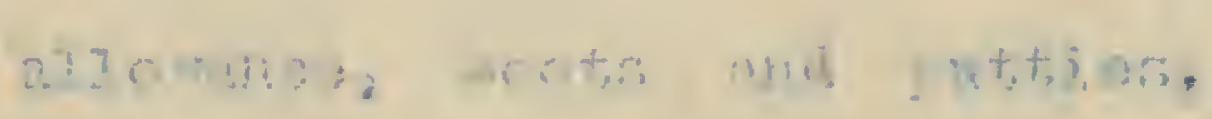

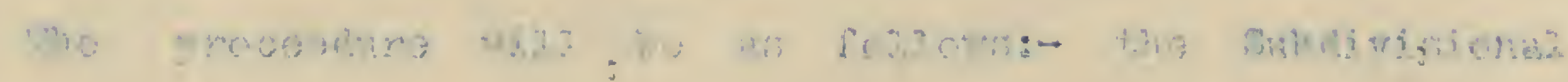

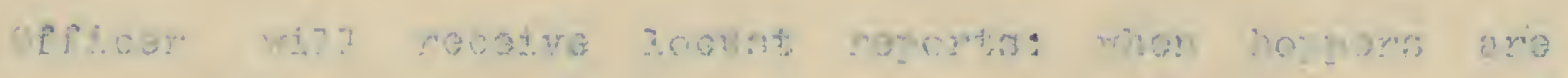

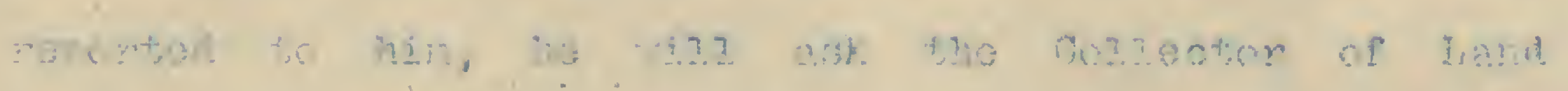

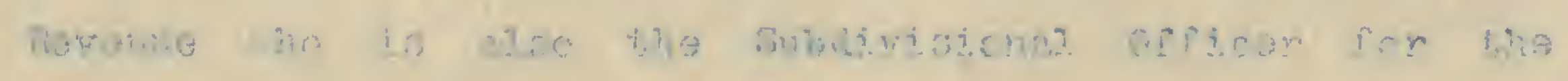

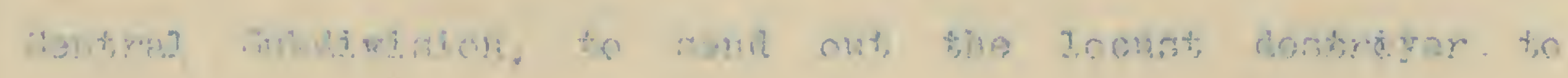

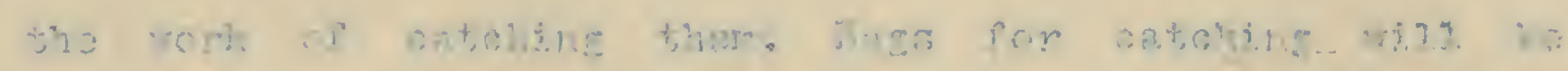

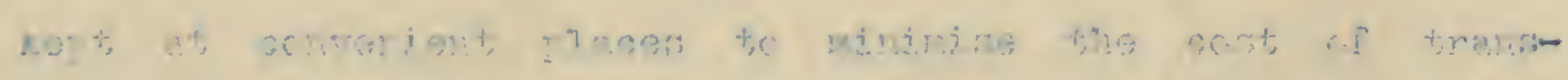

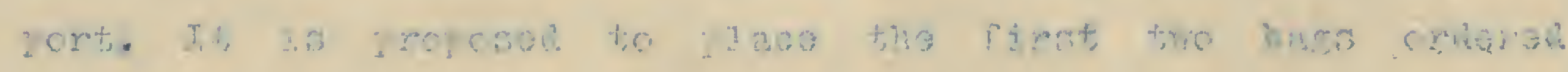

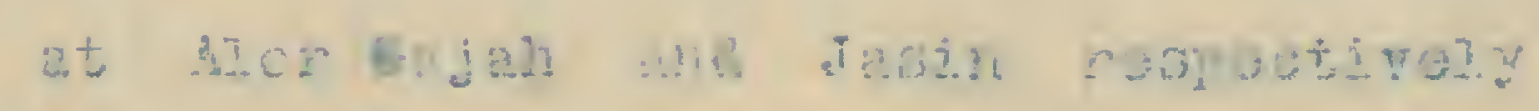




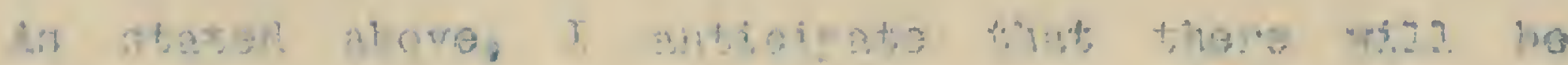

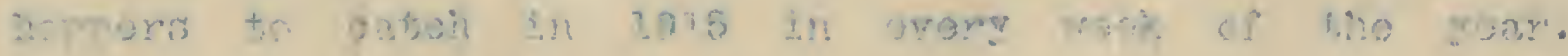

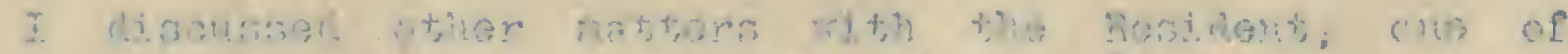

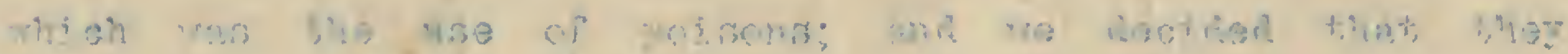

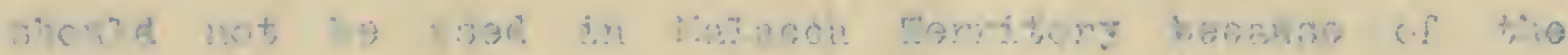

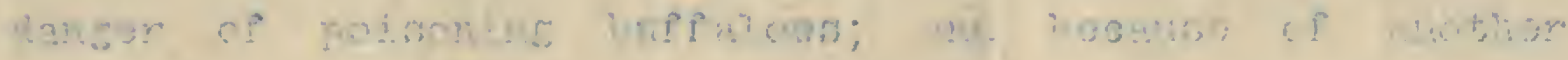

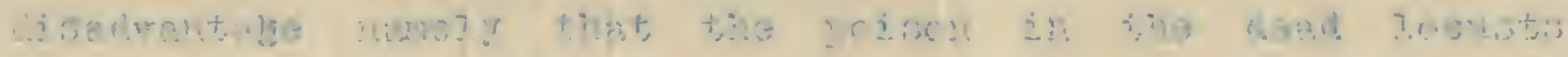

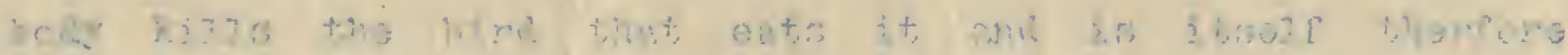

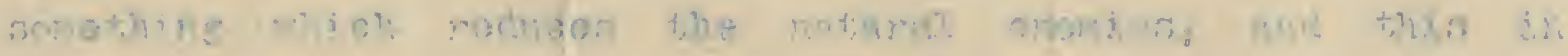

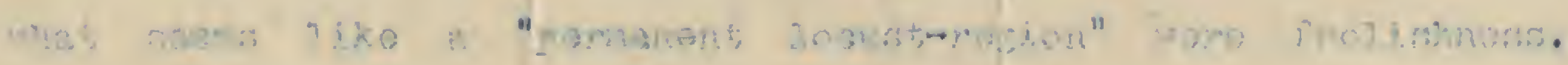

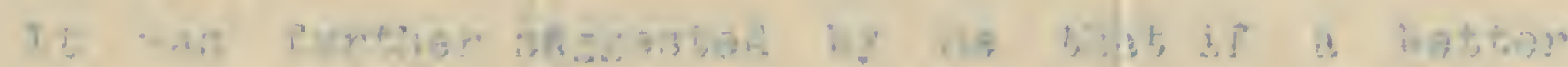

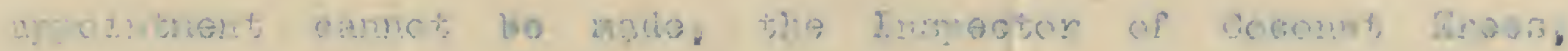

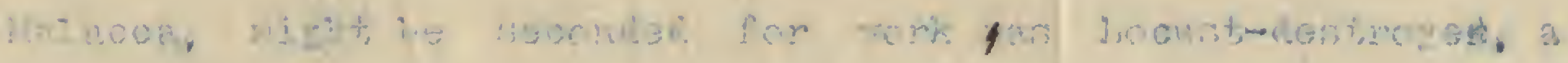

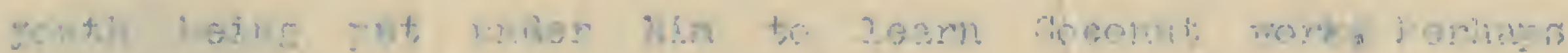

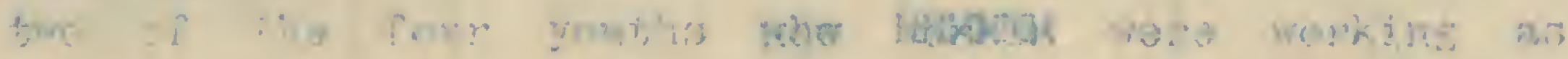

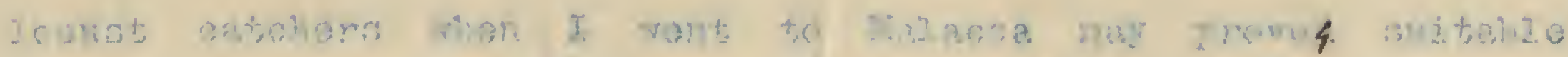

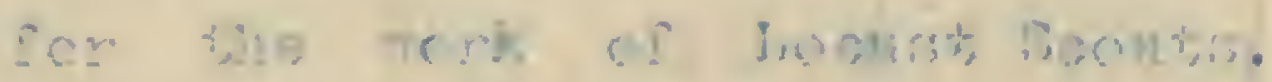

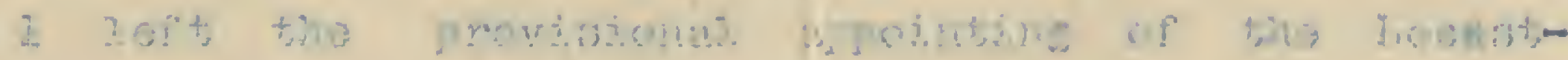

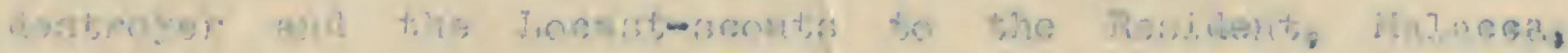

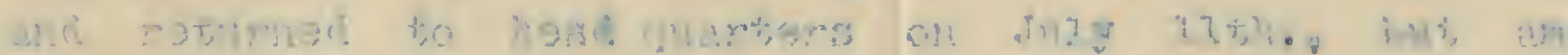

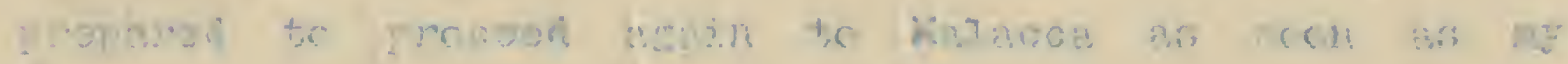

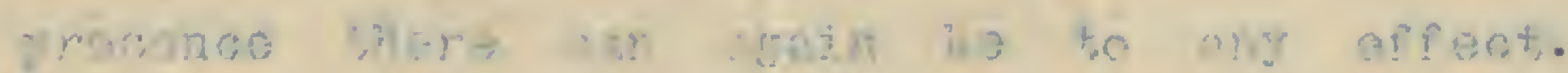

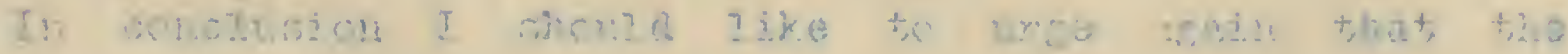

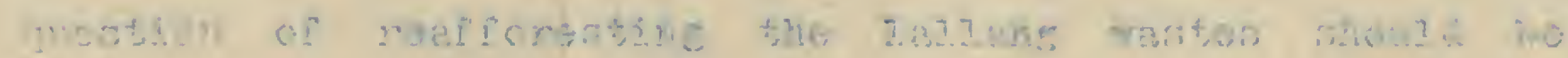

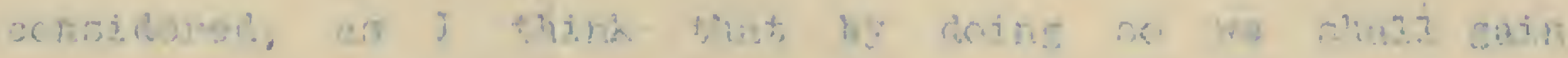

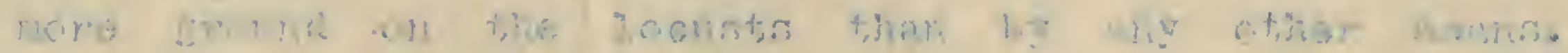

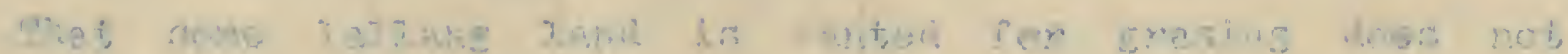

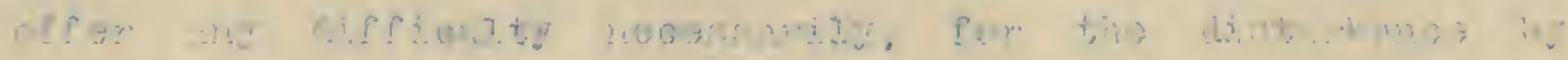

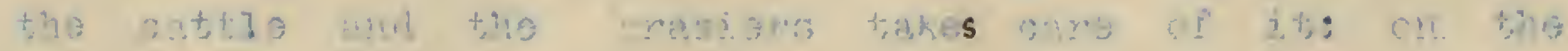

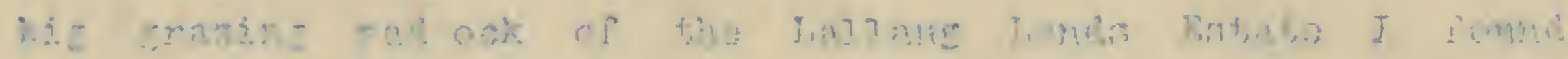




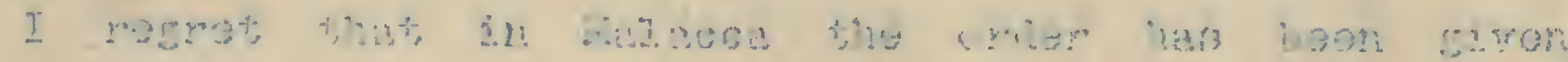

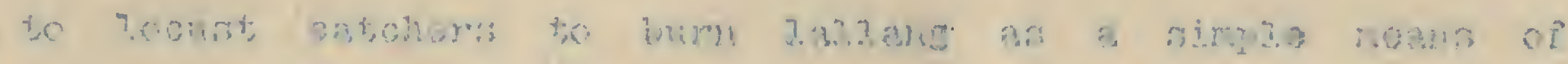

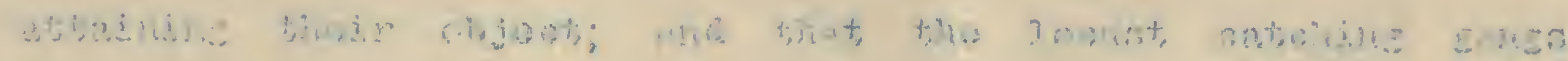

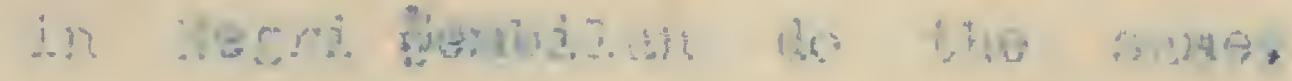


F. I. L.
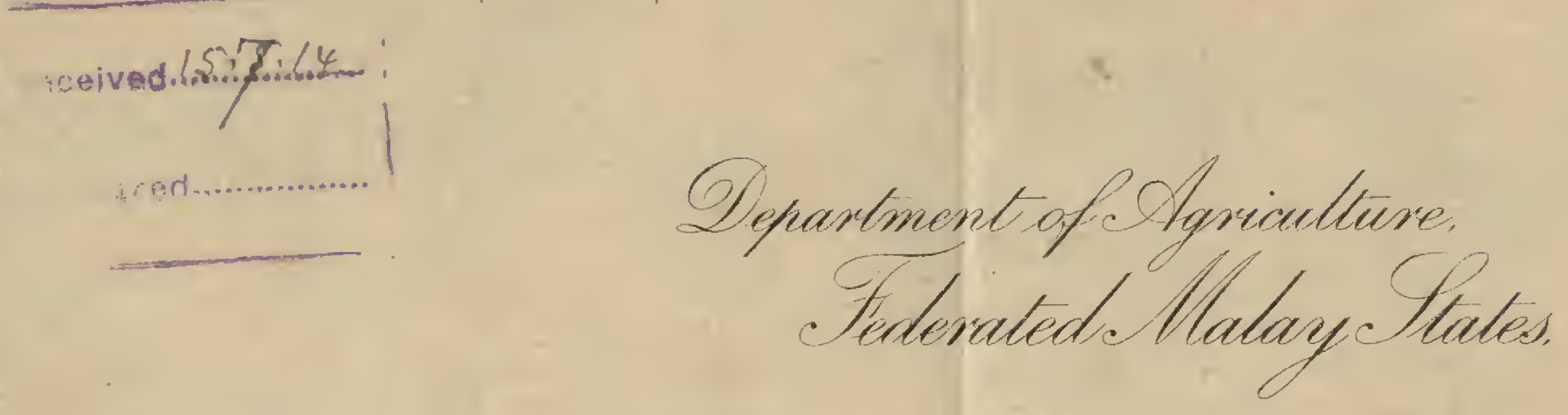

Kuolo Lmpor, 14 th, July, /OR4.

Sir:

Thank you very much for your nots of this nornine. The more I look into this species of rocust the less inclined am I to state definitery what species it belongs to. The following quotation is from one of the letters from the Phininines but I Frould not ploce too much trust in this:-

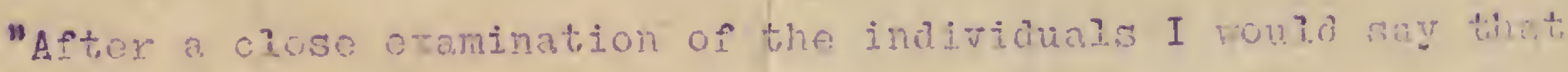
the specimen of your P. donica secms tio be identicas with P. migratoroides of the Phill: winch is one of our most destruct grecies".

My bulletin is oniy paiting for the arrital of the colomred putes from Englane wich were sent home over sir months agso:!

With stocineinskon in cantivity combation took poce

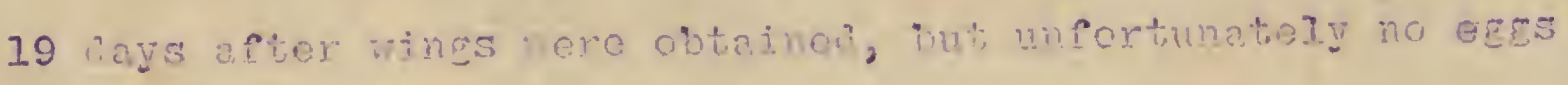
were 7ato. I shomid say that chont one month elapses or a

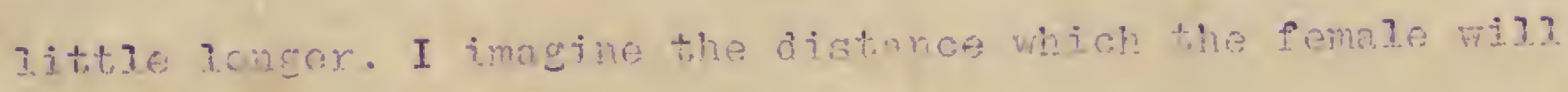
wondex will depend largory on weather and food conditions but it courd certaingy traves a very consiofanie oistance.

XH. Burkin Esar:

Yours sincores $\ddot{*}$ Helnut.

Direotor of Botianio Gardents. Gov: Entomociat, F. M.S. singarure. 
MEMORANDUM.

from

Sow his Arches.

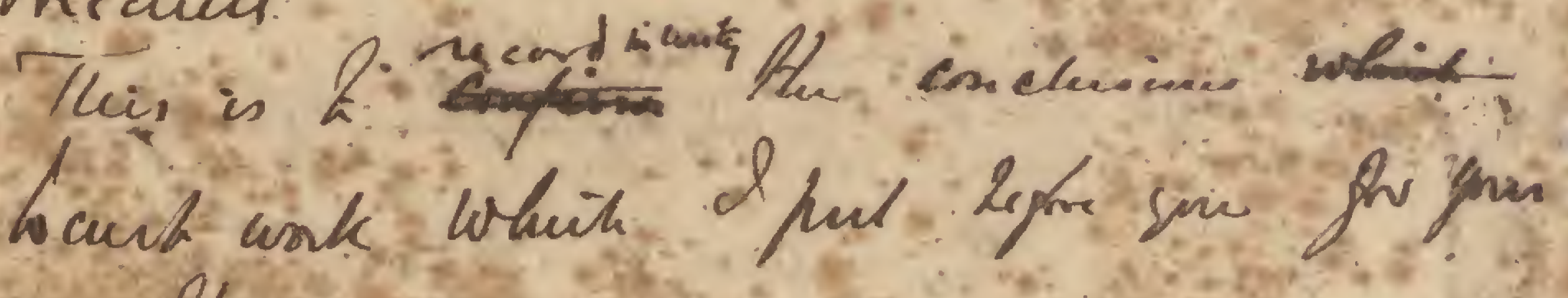

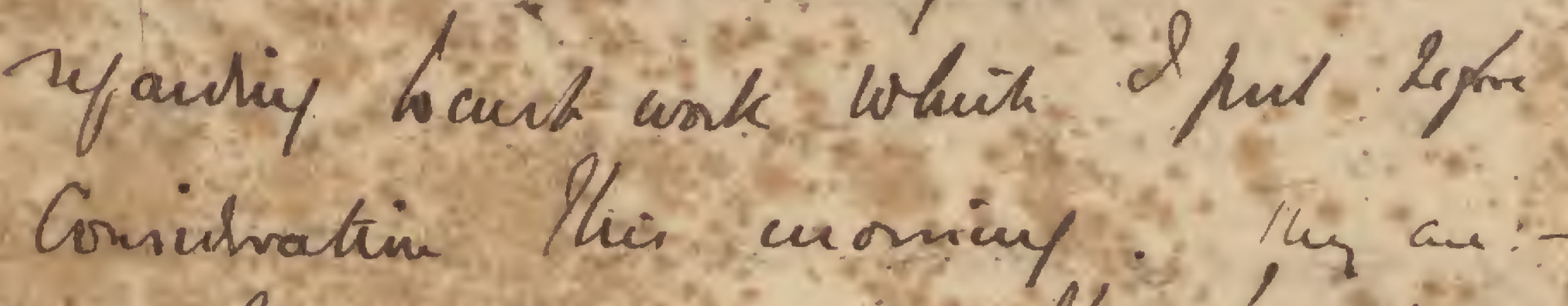

1. Hat supprenimi of the baits is owl 9 the

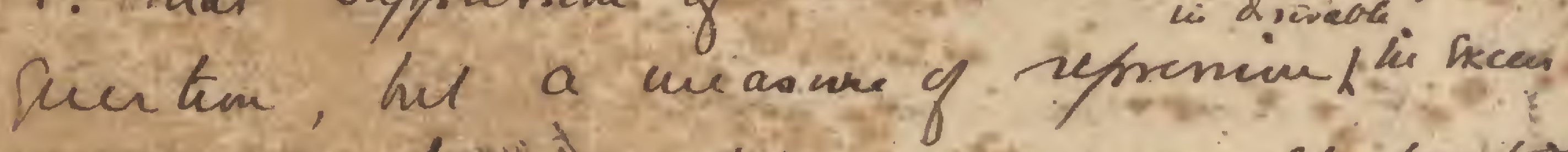

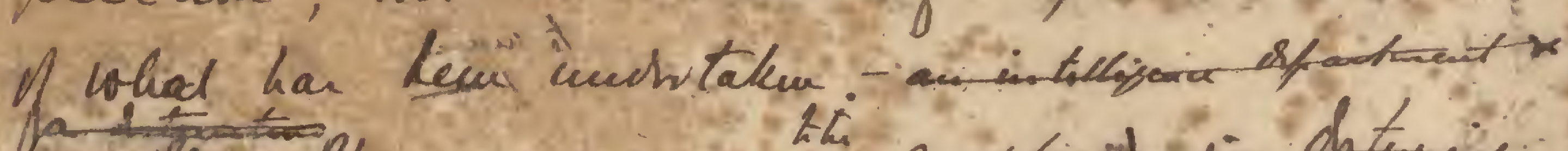

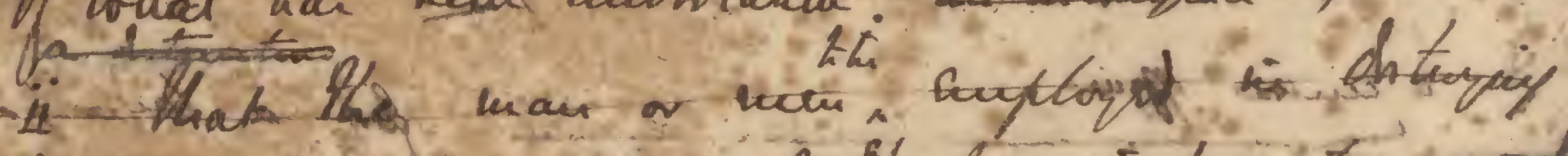
tu bait o

can is ait the link the is neernar that

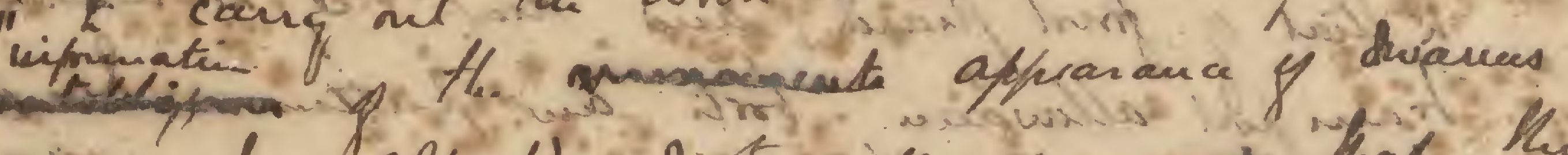
sting bo couch sisturiatical an that the

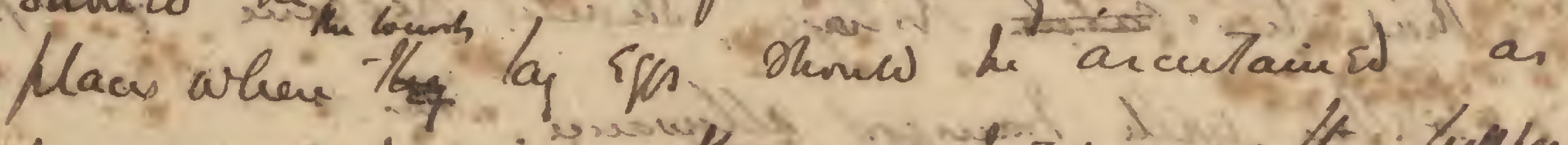

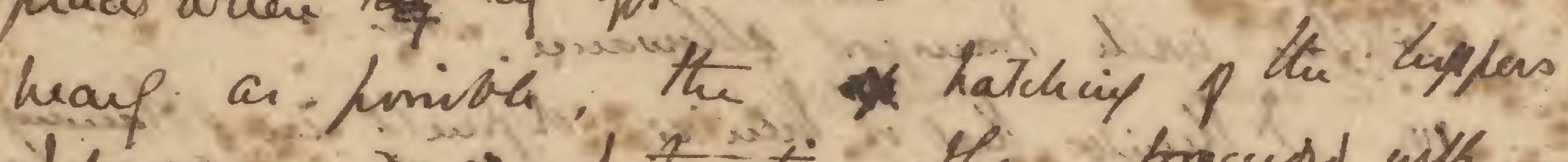

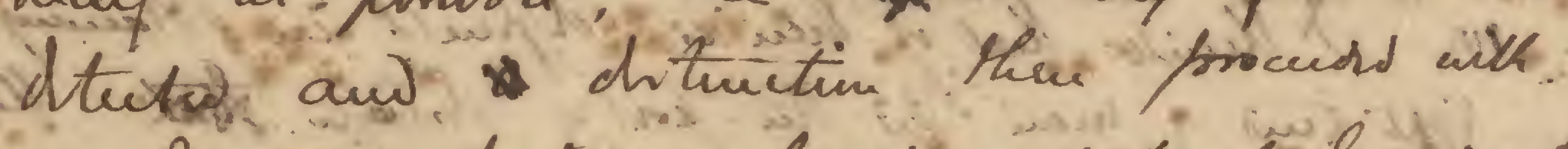

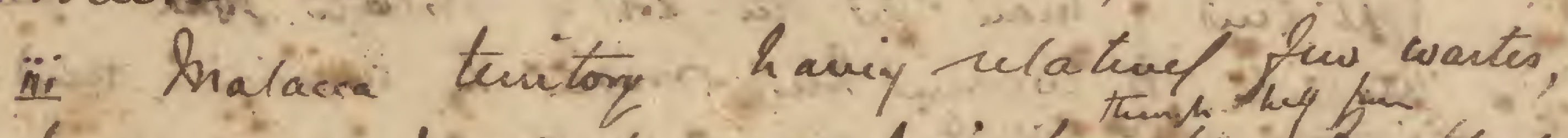

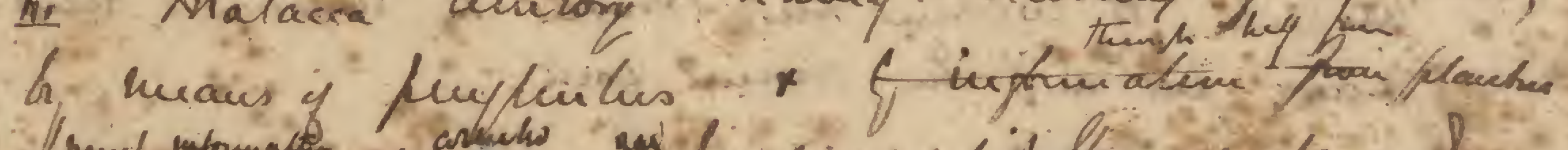

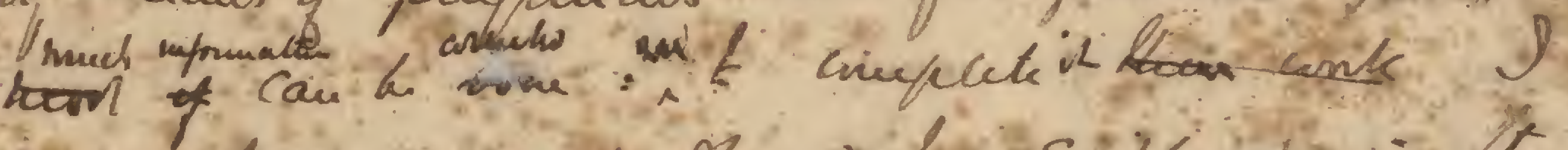

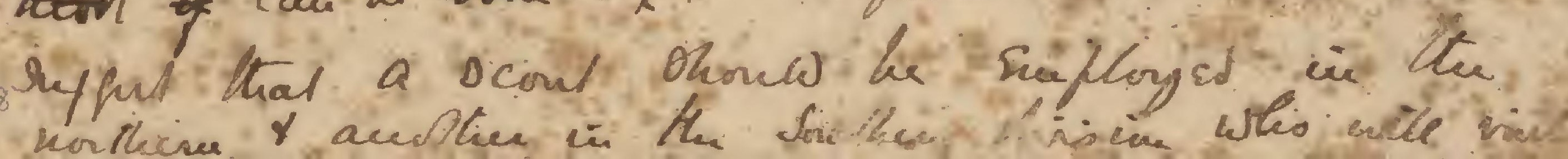




\section{He Álace wastes in iotatur}

aced racts

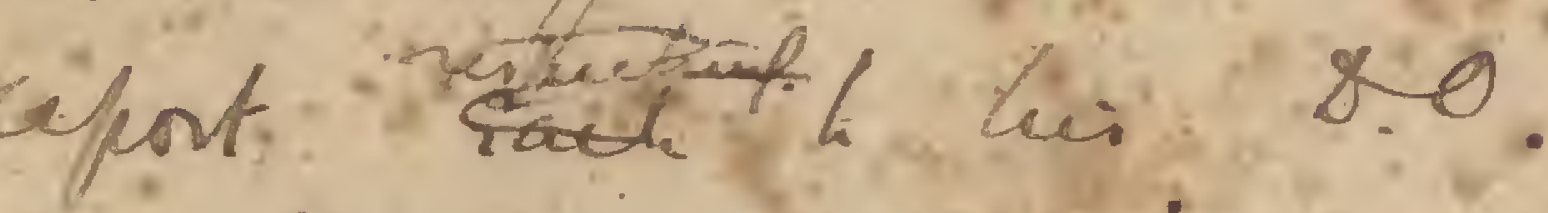
as the ivaitabl enprisative

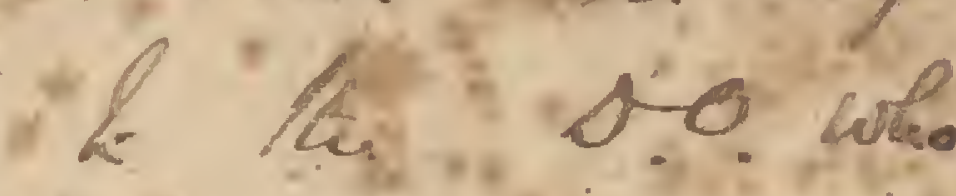
Ohive

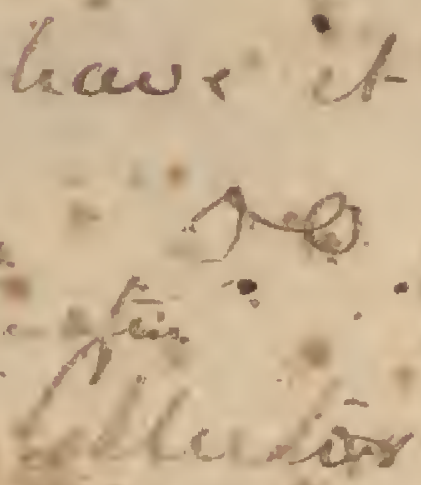

\section{if it ile}

Whor dofil a

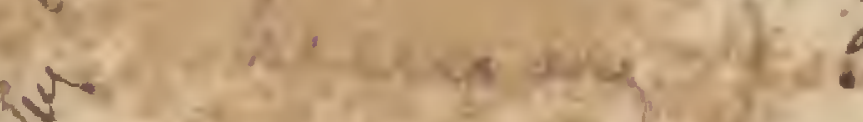

\section{x las this the \\ igce}

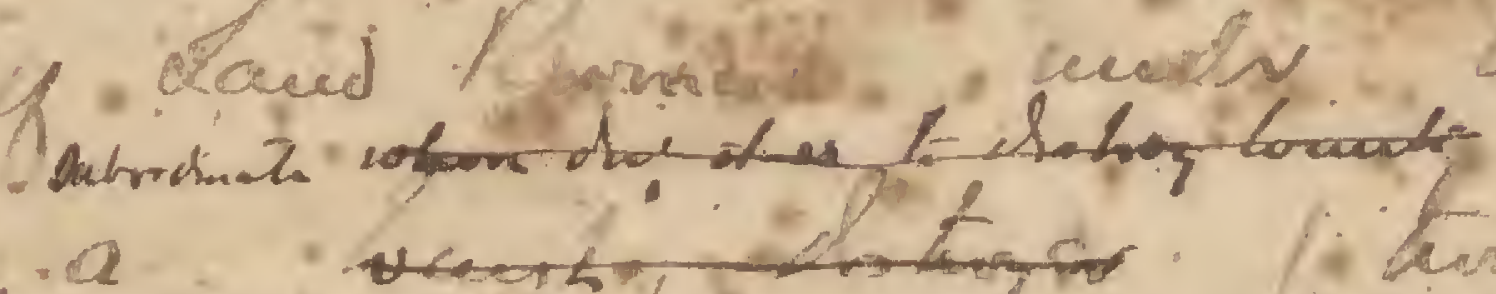

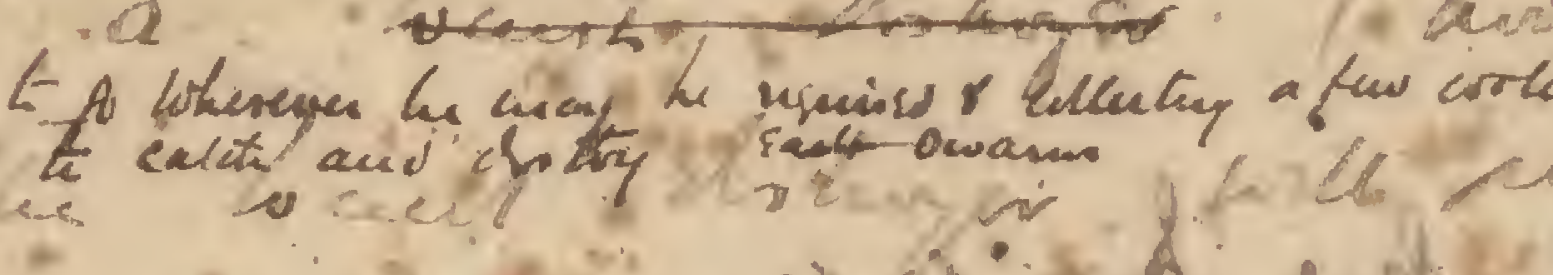

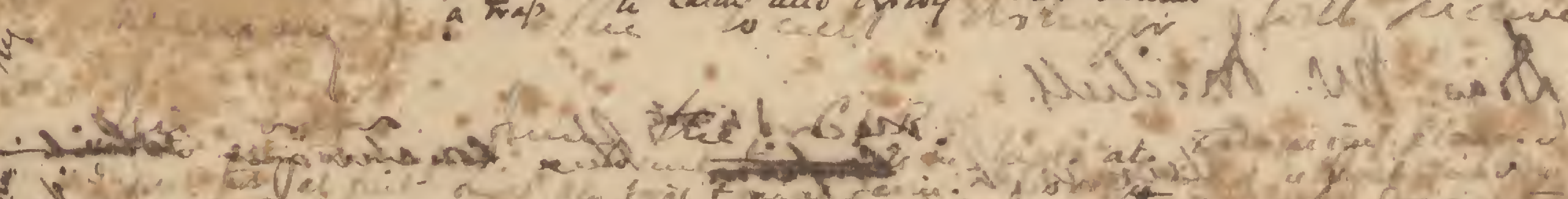

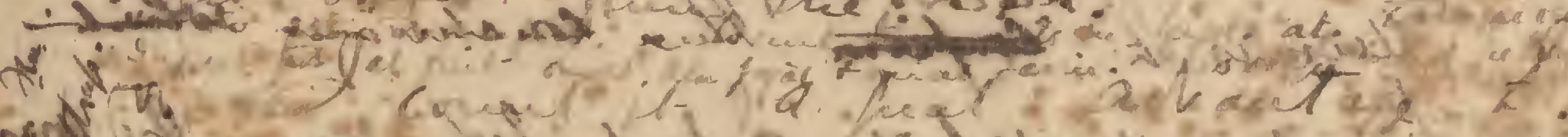

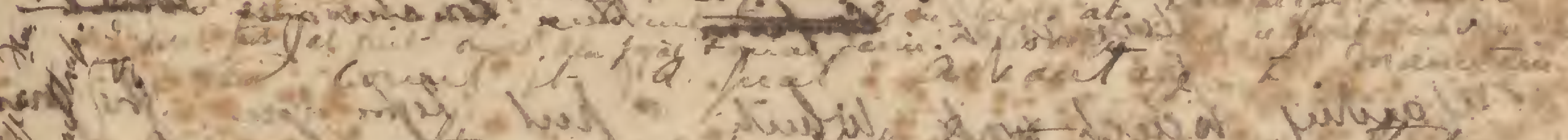

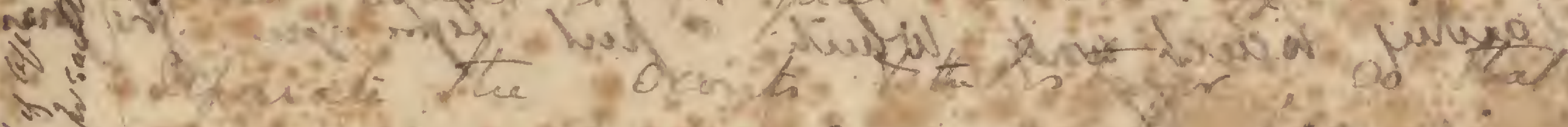

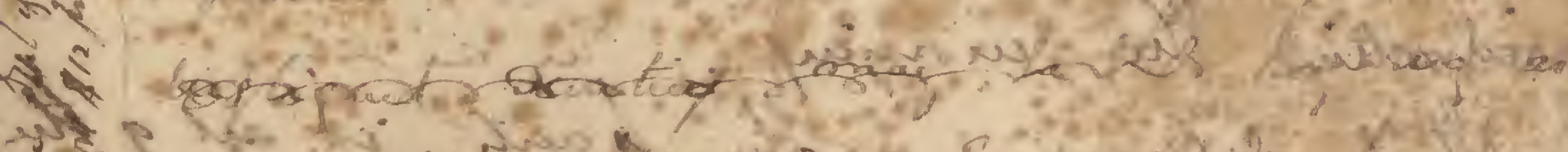
in $P$ as $x$.

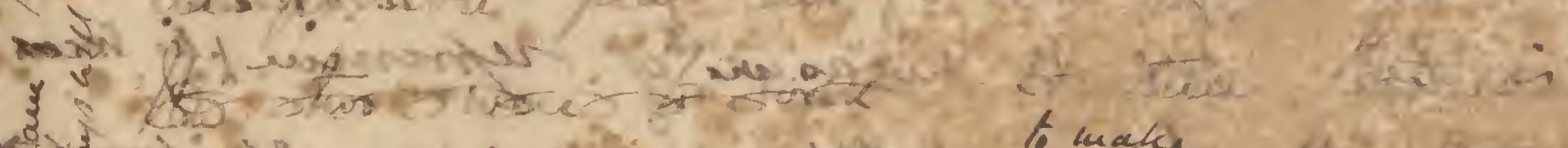

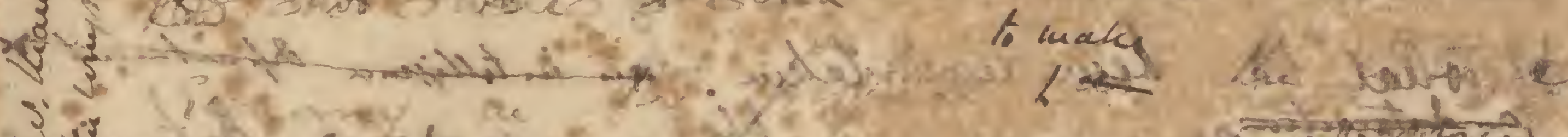

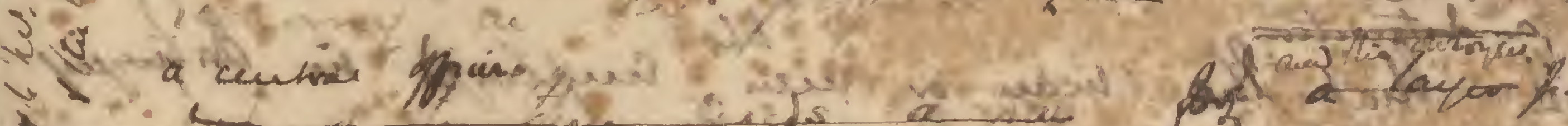

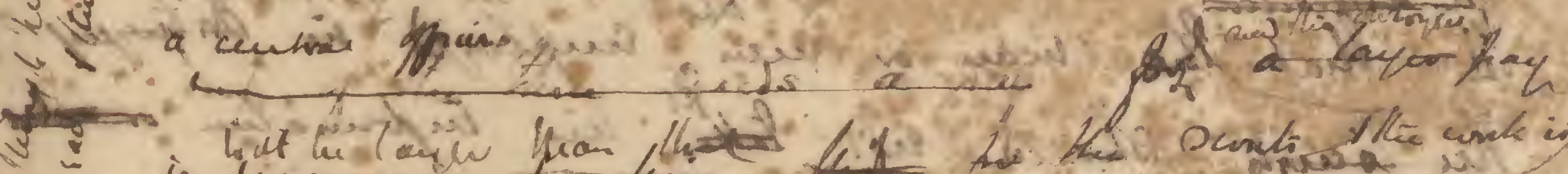

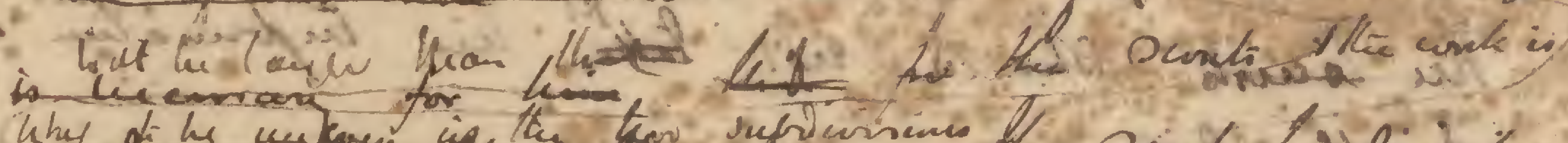

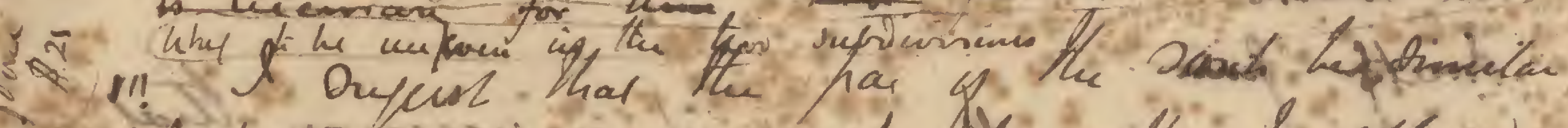

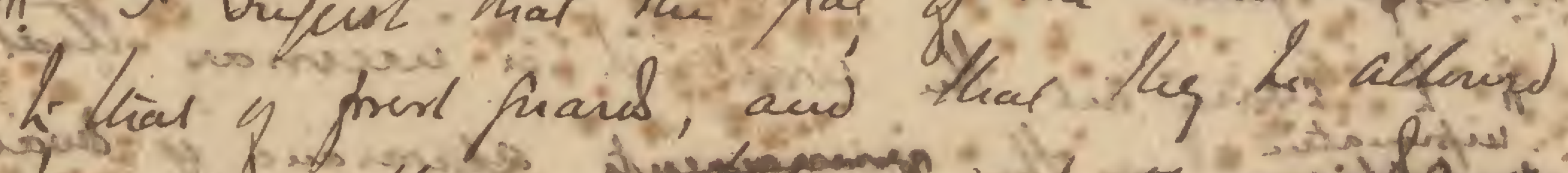

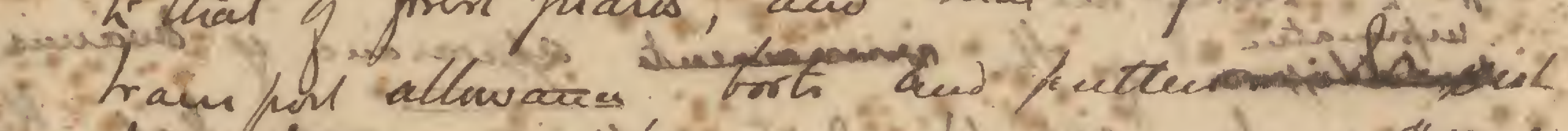

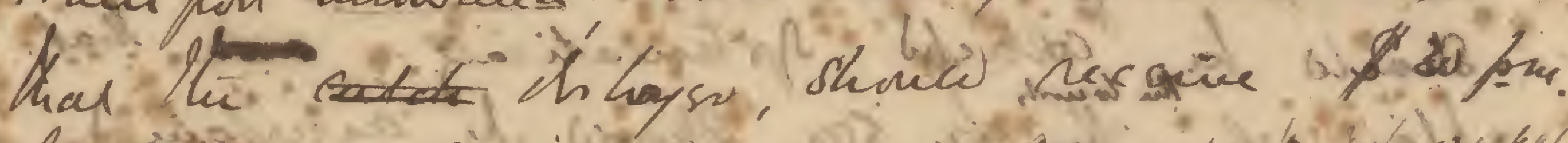

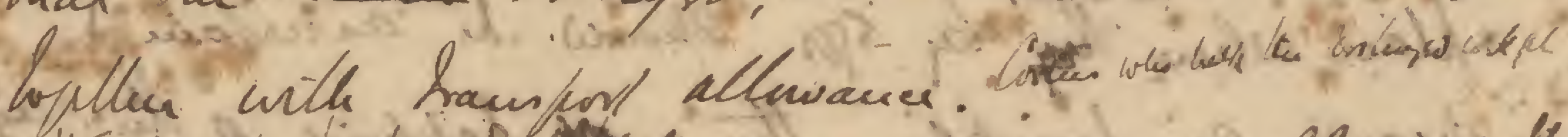

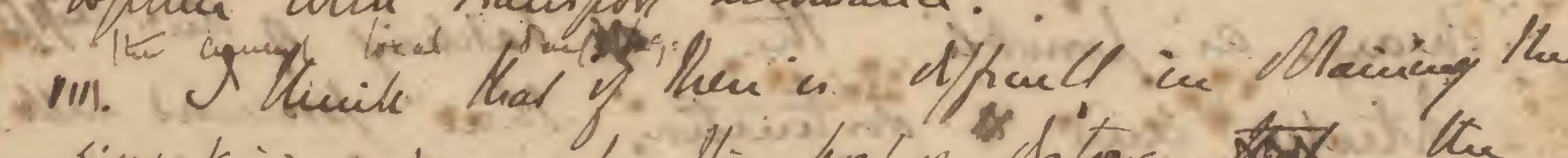

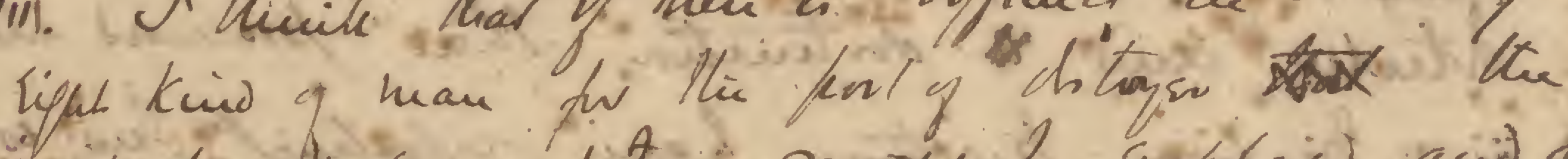

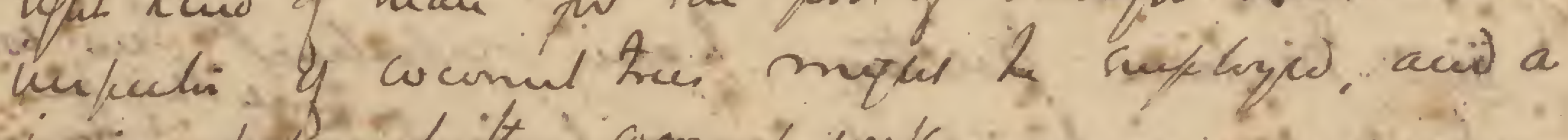

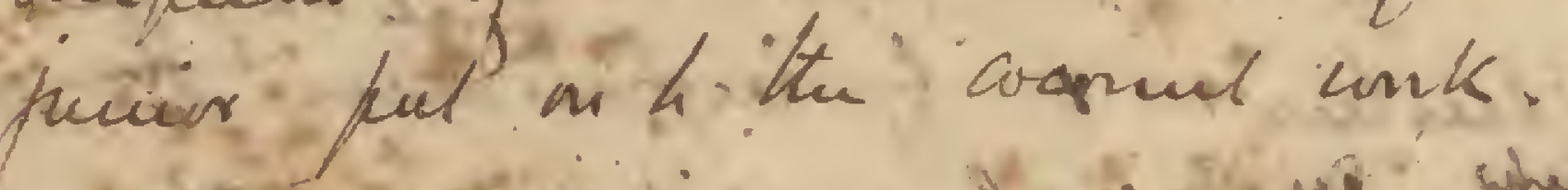

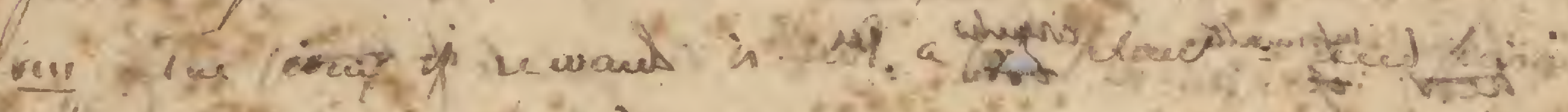




\section{aepartials of Acriculature \\ Rederaçed Malay gotades \\ KHa1a, Mroter QYsis May 19.4}

NC. $154 / 14$

Sin,

I hava the nonour to infore you diat durirs mg rocents visity of

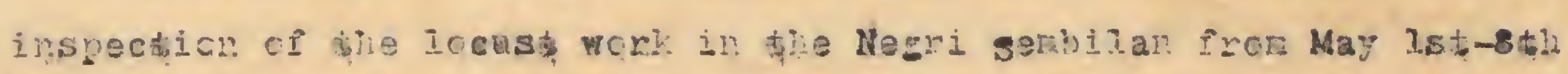

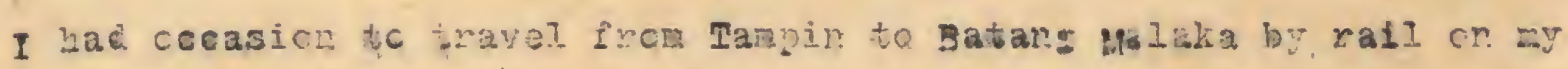
to "Iu Gerenchen ard that fort riles alcng the line in ualacca fror Keru to Tebong and beycud there was amcst a coutinucus swam. cf Iccus in the 4th and 5th instar and just flyine. hlis swarn will he a very large cne and is guite likely to enter the segri Serbilan.ucrecver there is no reascn to believe that it is the cnly swarm in that district.

2. cre of the Matay Mandcrs worring in the coast Distriet, near Penkalan Kempas a 3teady and reliable ran-infoured re that he had been told by Malays that lcenst, cecured in large quantities in 3everal rarts of Malacca besides 


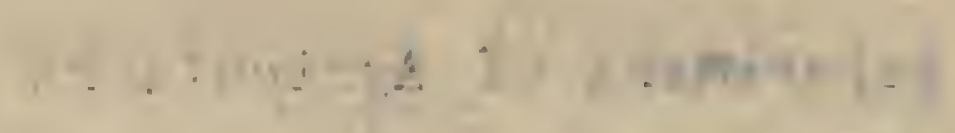

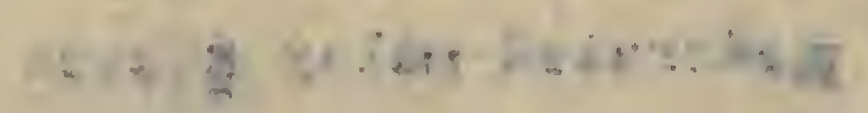

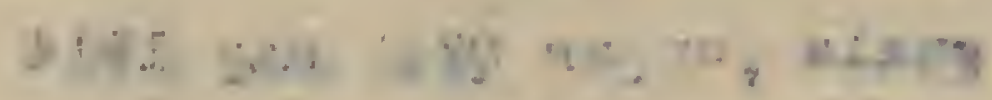

gepartaent of Aericul tmre

- eàrated via tos

an+a!

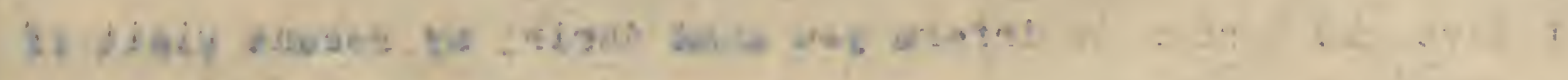

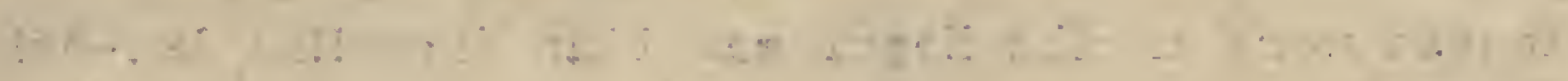

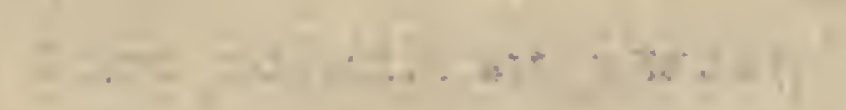

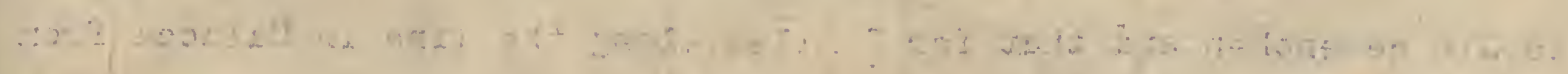

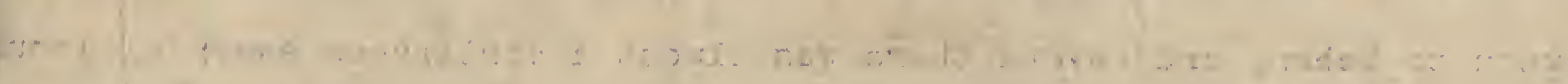

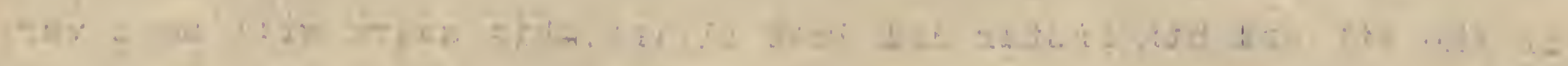

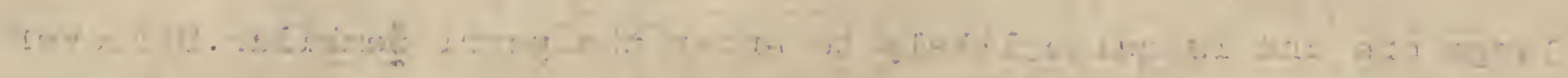

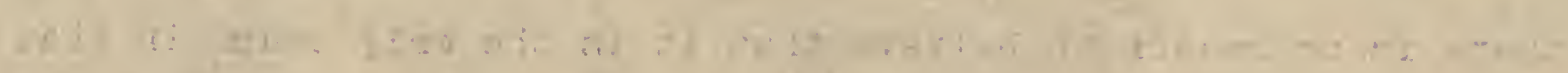

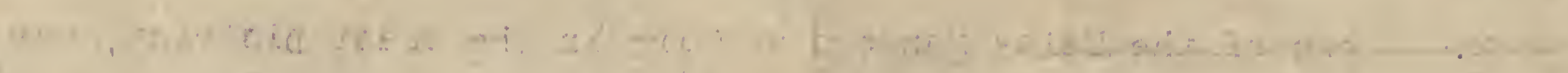

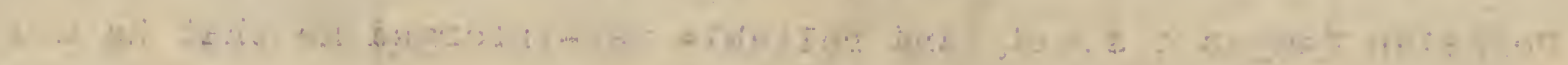

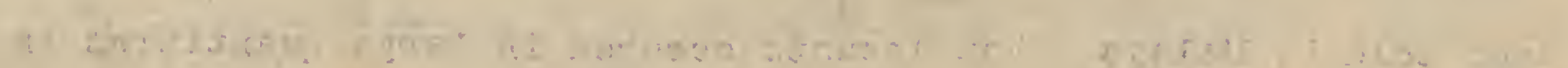

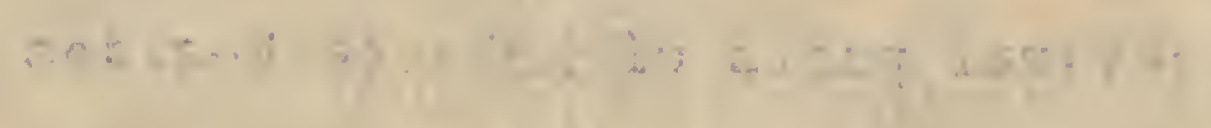




\section{5}

Mino: $2024 / 132 \%$

Fron the Reringt, Maracen 25.7 .14

Sis.

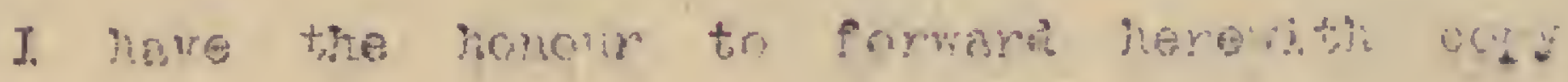

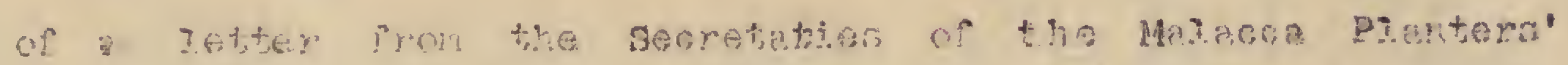

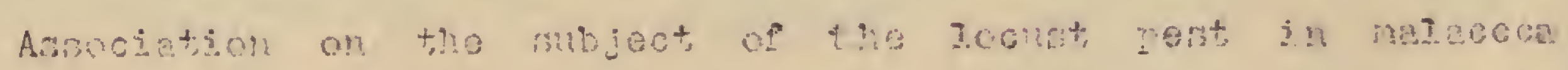
and I. do wo heoance in the rast pareacrandi of the

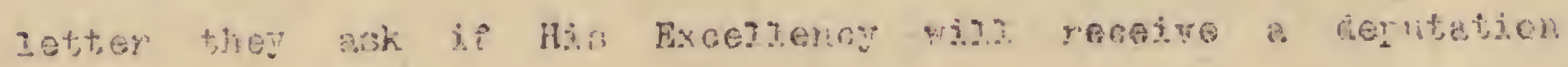

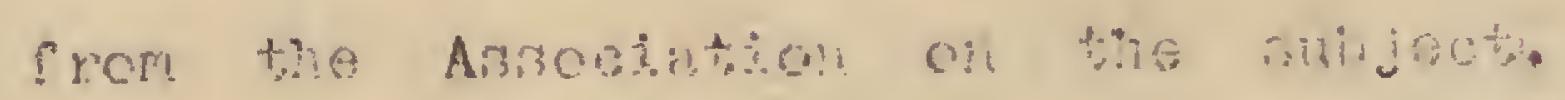

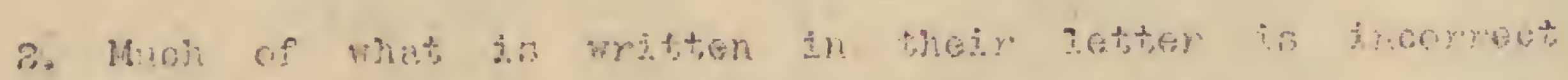

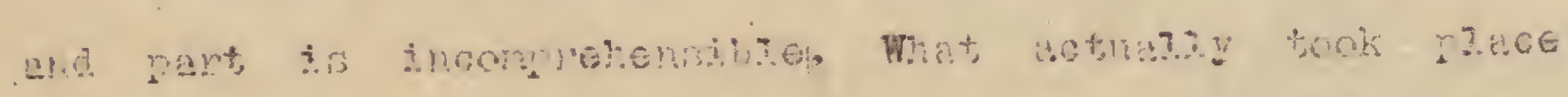

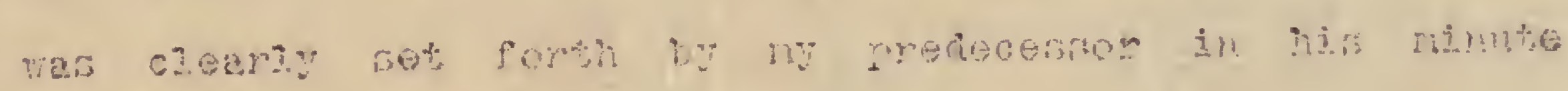

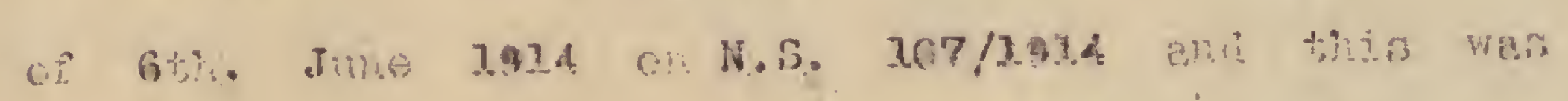

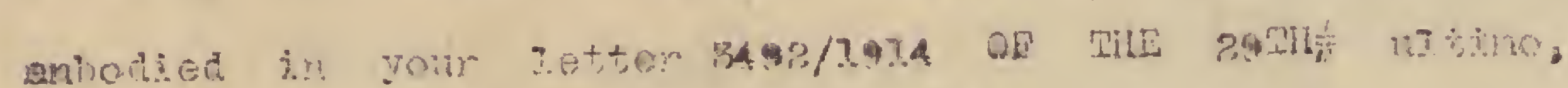

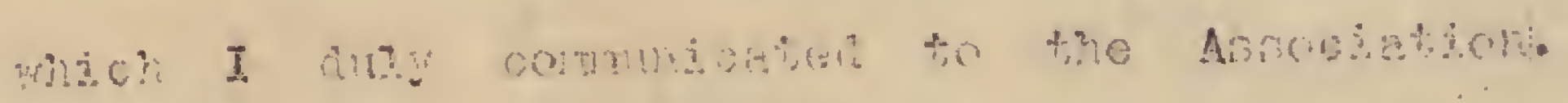

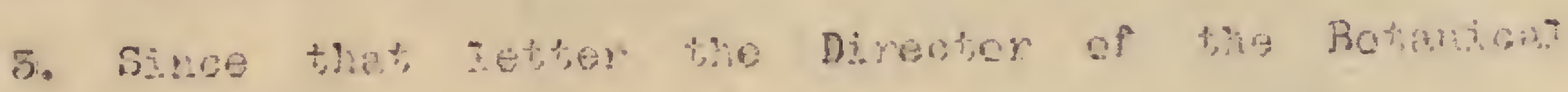

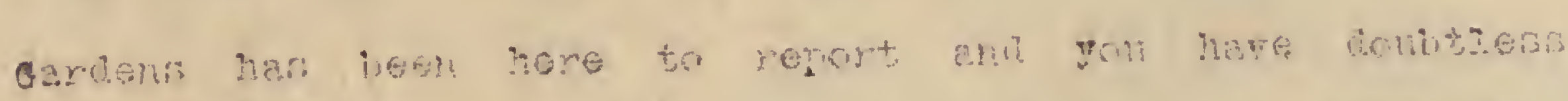

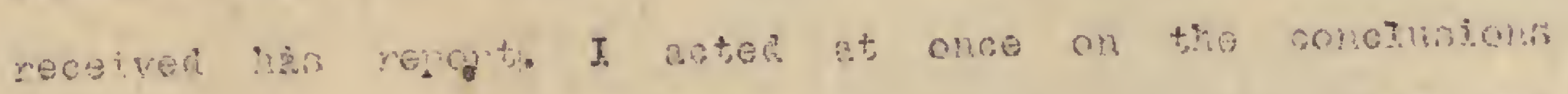

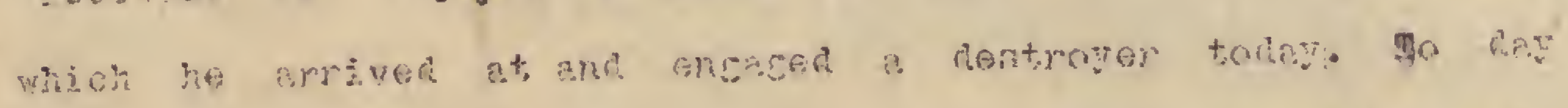

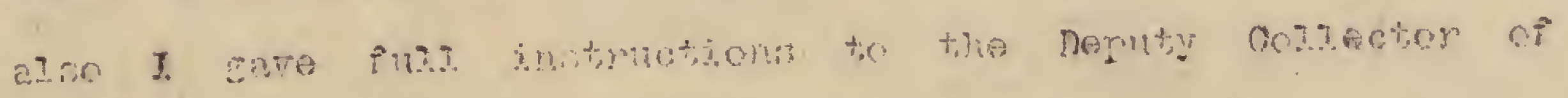

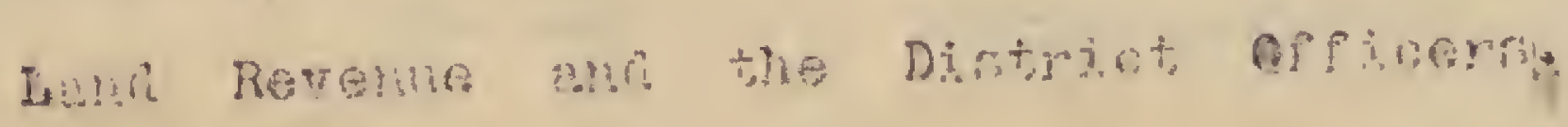

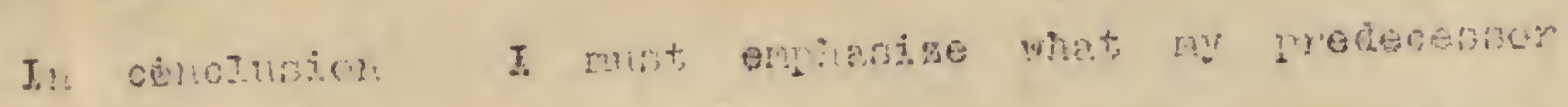

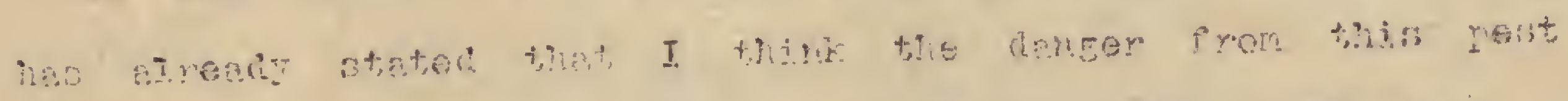

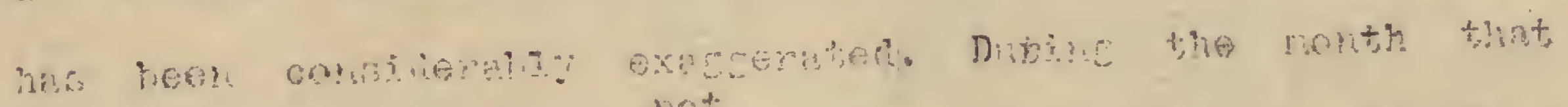

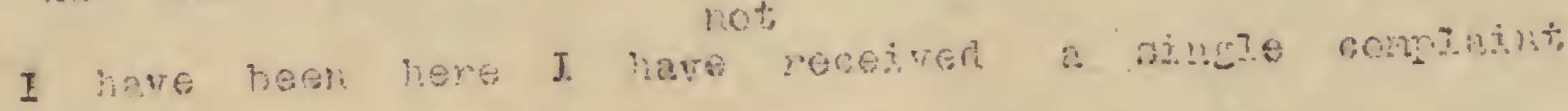

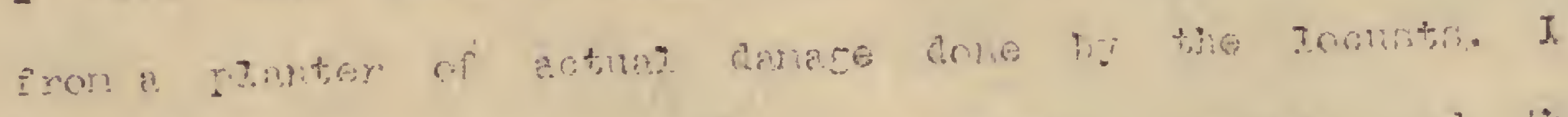

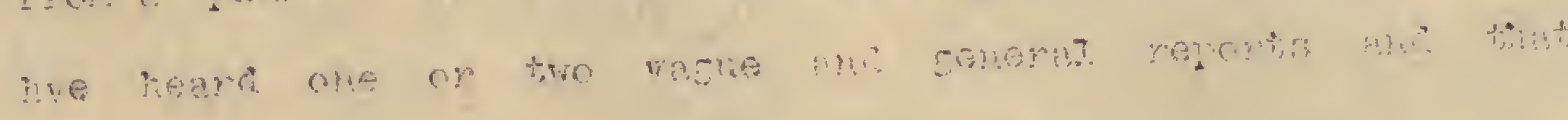
is 8

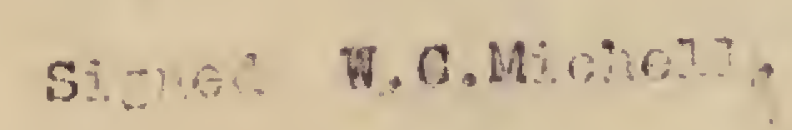




\section{Suclosue \& $5^{-}$}

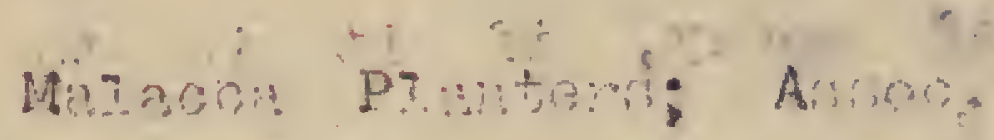 \\ I0. Ji: 12.4 \\ $\sin$

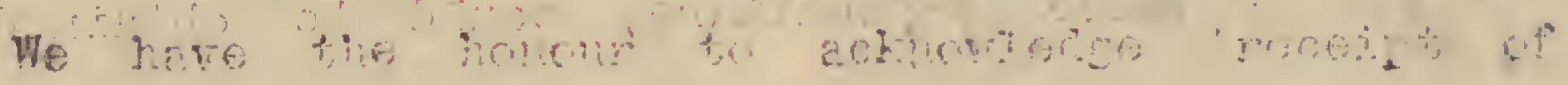

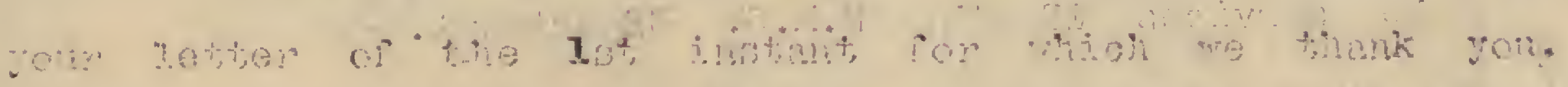

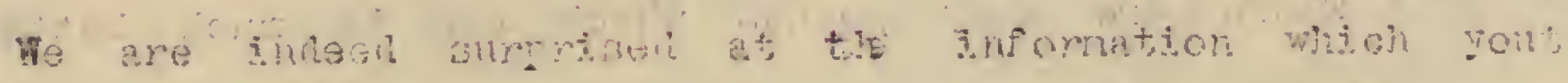

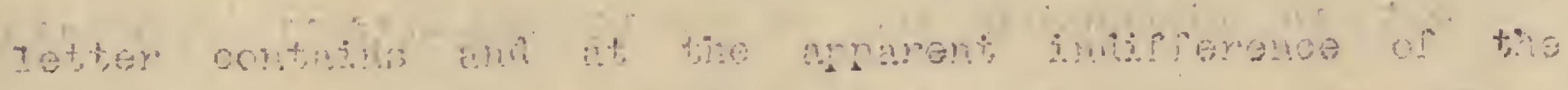

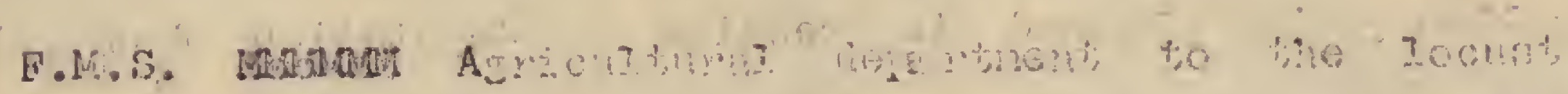

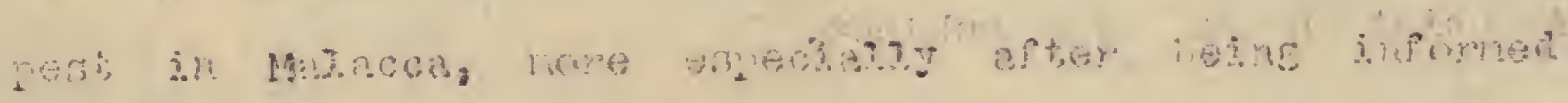

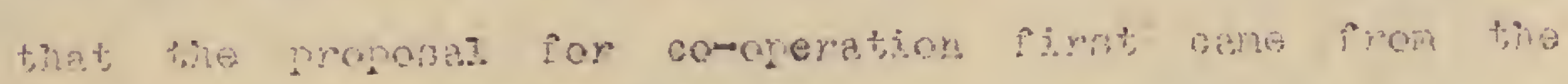
[.M.6. Government.

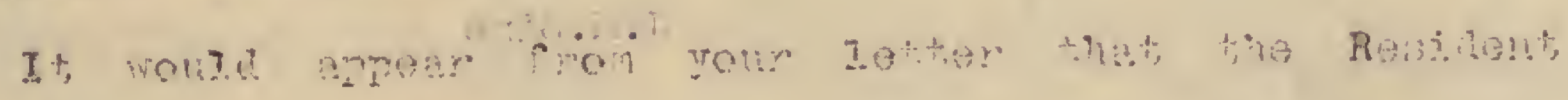

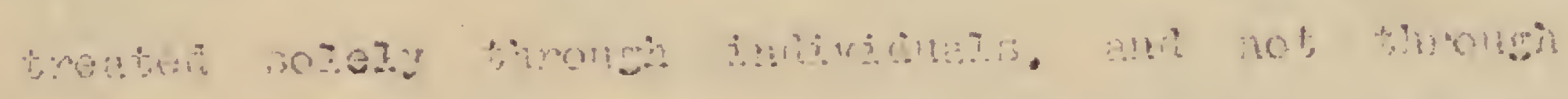

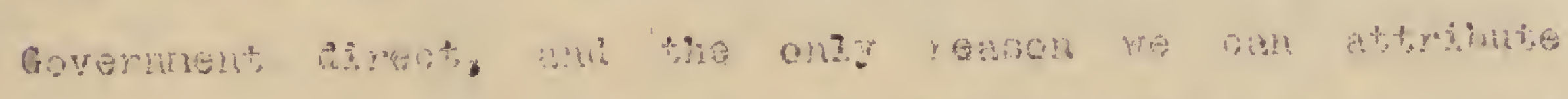

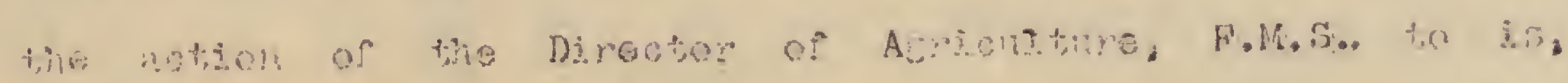

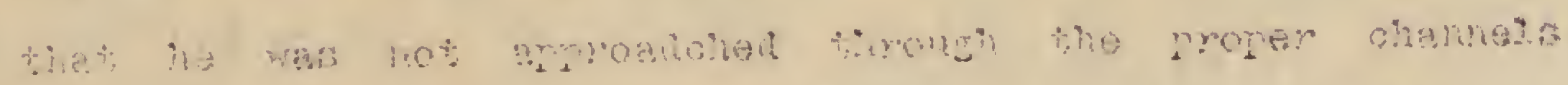

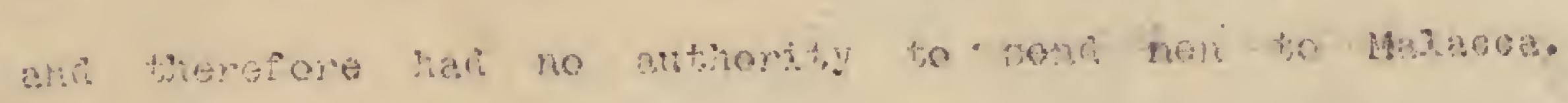

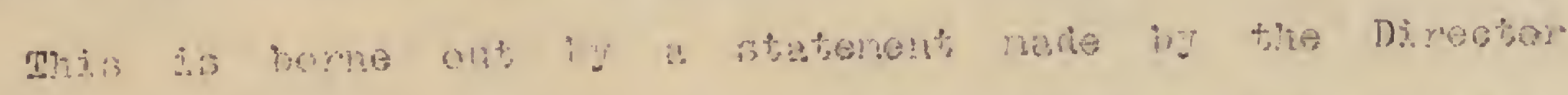

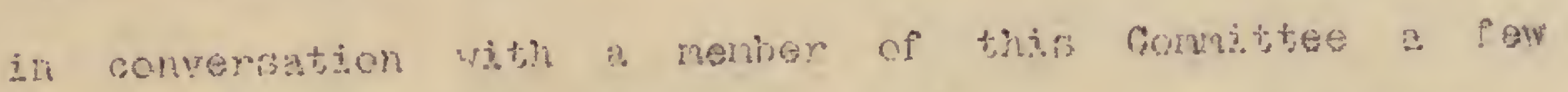

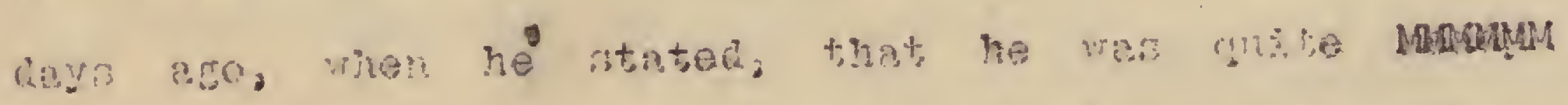

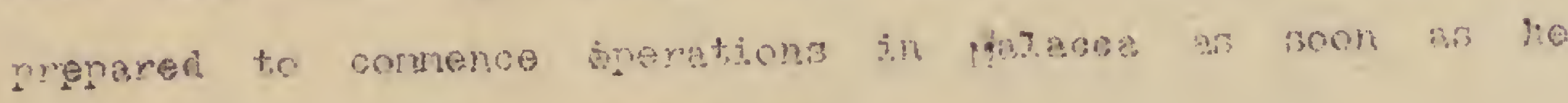

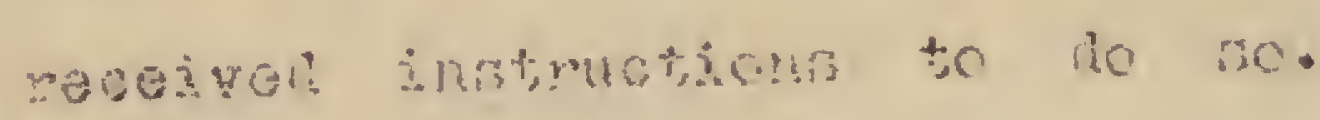

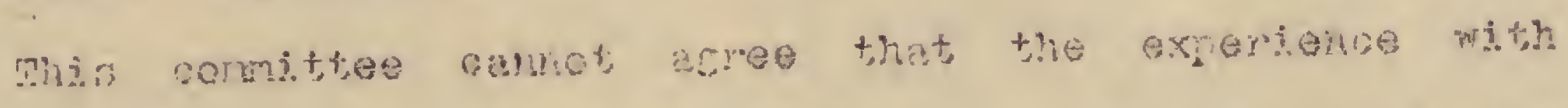

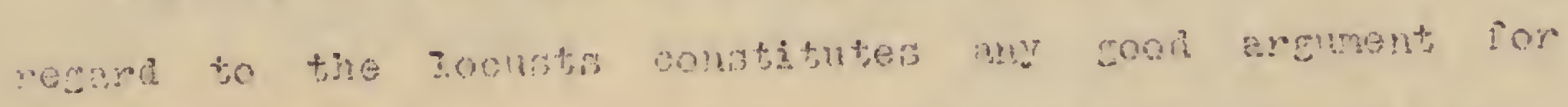

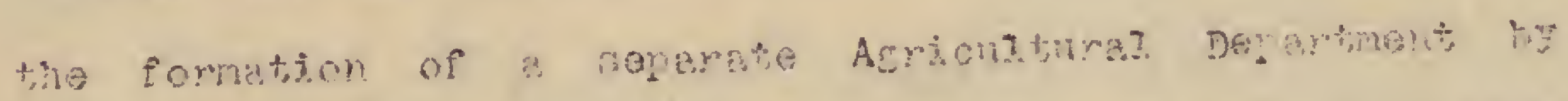

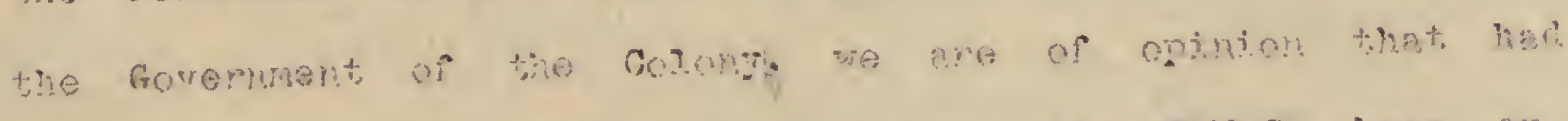

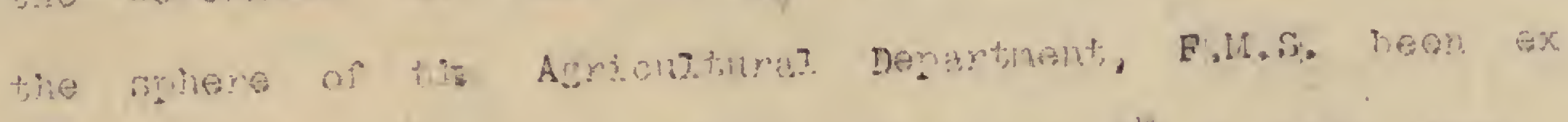

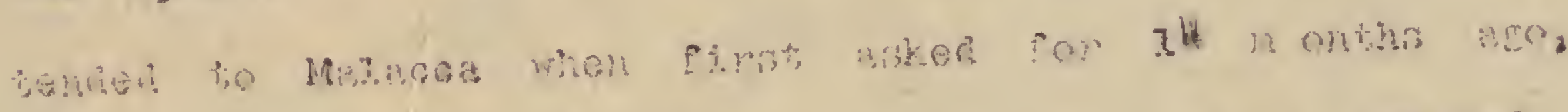

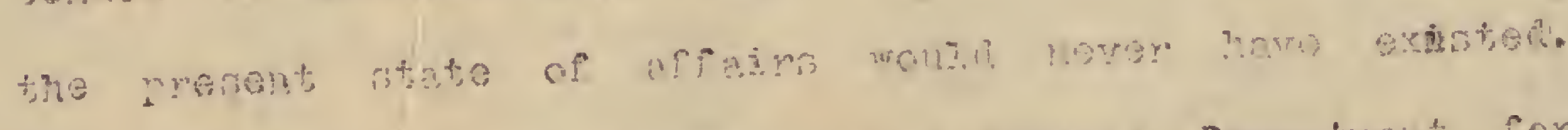

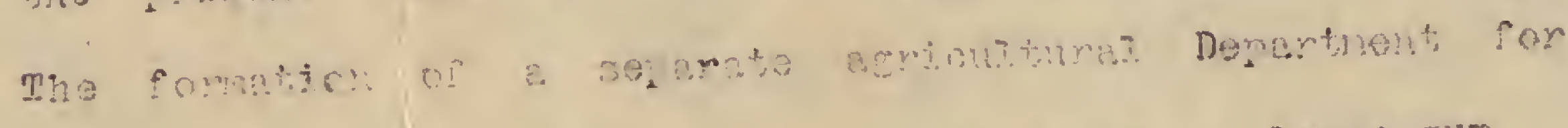

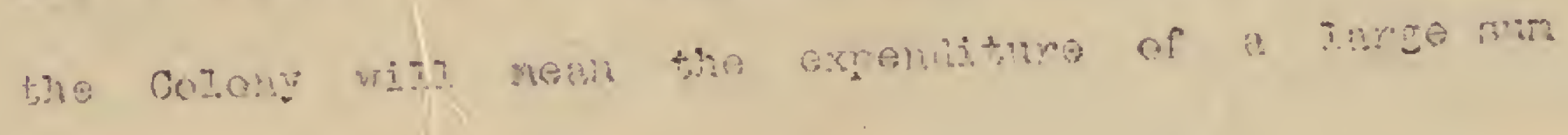




\section{$15.6,34$}

Sir.

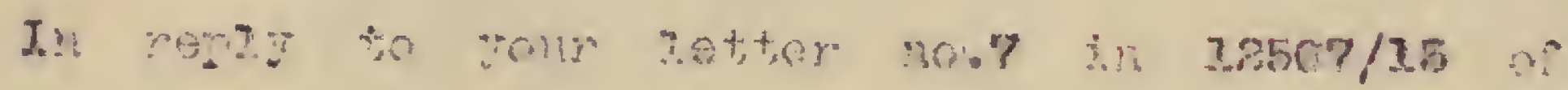

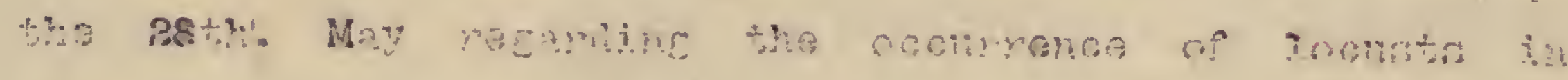

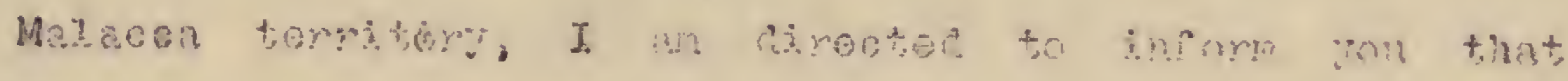

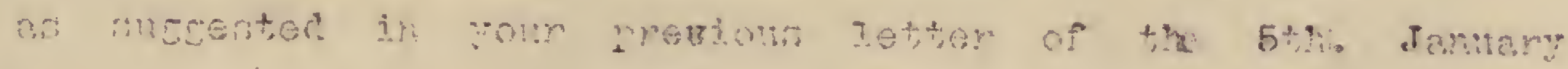

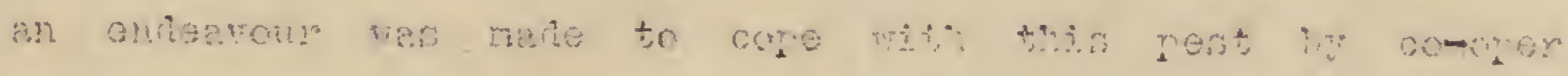

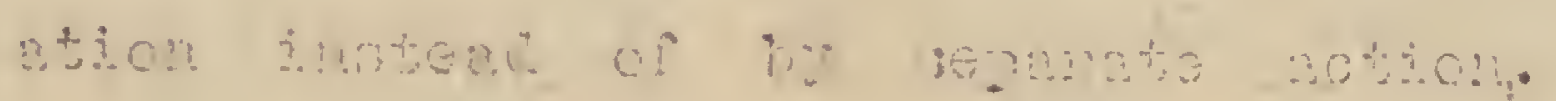

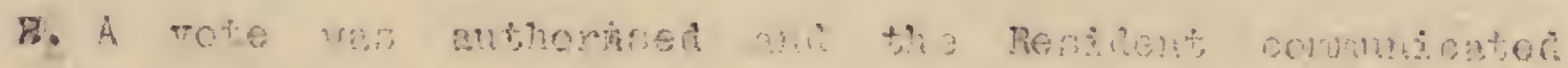

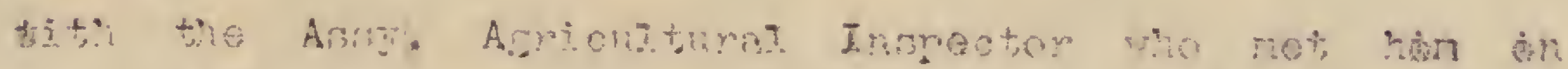

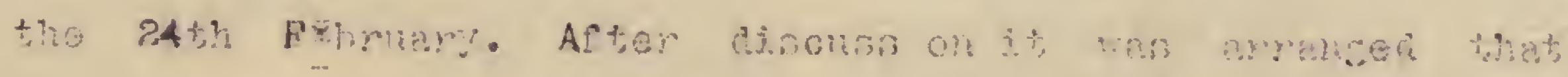

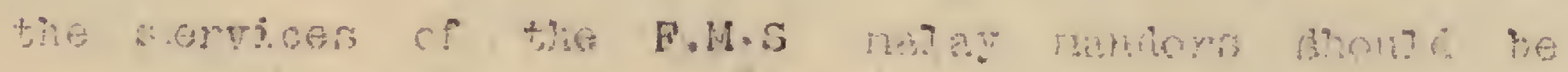

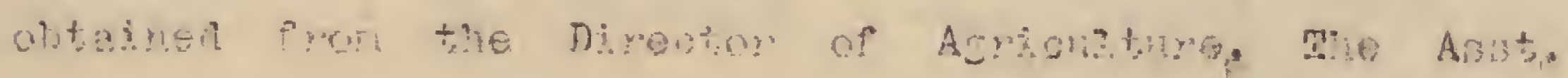
Insertor was to aysy for them.

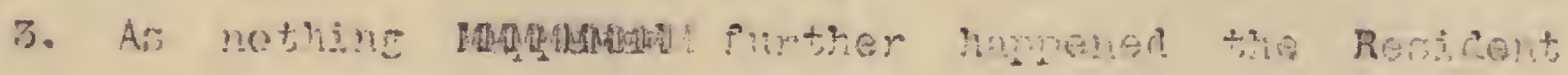

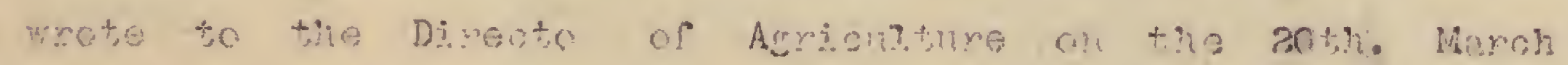

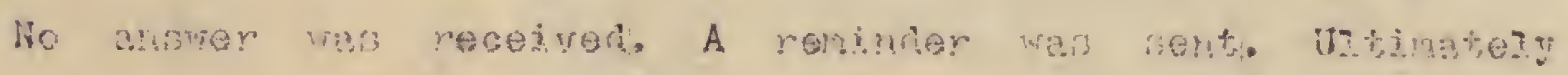

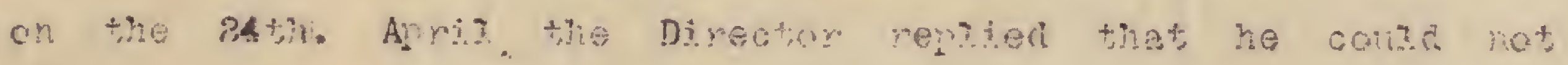
nare the mon asken for.

4. Since that time the Rerinent har heon marume

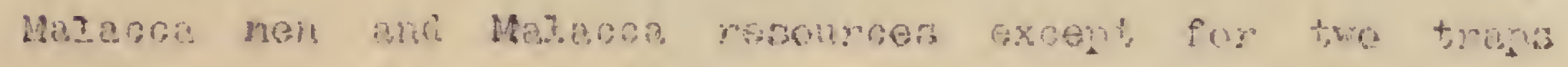

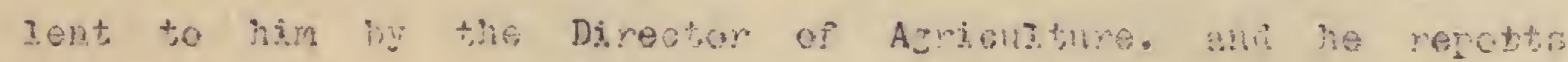
that though Mainoce is not pree fron the pat wing in

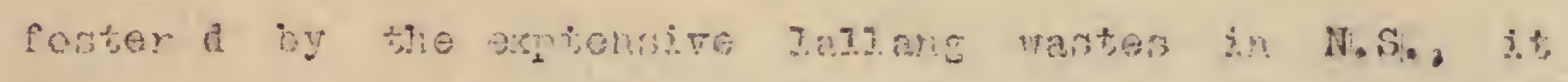

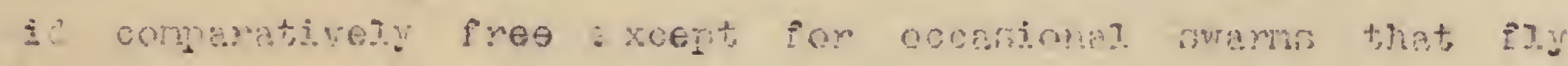
over the horler from thene wastari,

\section{R. T, T;}

ro Inder secretary, F.M.s. 
The Tebong IRubber ano Capioca Estate, Timited.

TELEGRAMS: STRATTON, TEBONG.

TELEPHONE: 38, MALACCA

P.O.: TAMPIN, F.M.S.
$\underline{R L Y \text { STATIONS: TEBONG: AND PRIVATE }}$ SIDING.
17. 7

TEBONG

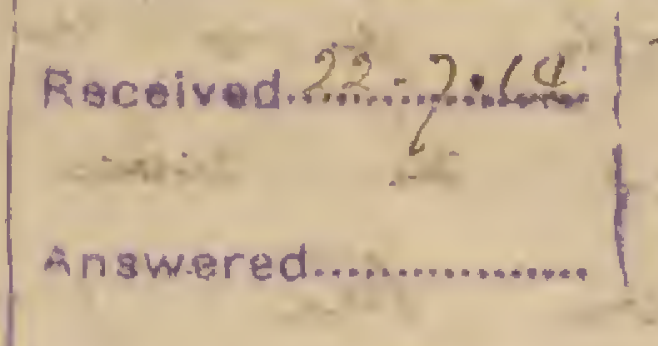

IgJ

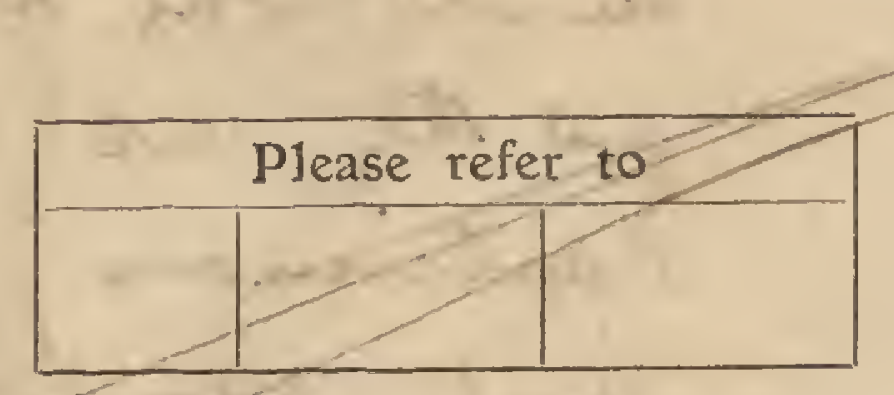

Acarkir Burkile.

Thank on ving mitch fori cors 1) Yrume Bucletin. L was never the improsion that then was a biger tar than this (ko boute deat sone thine ago) Chich

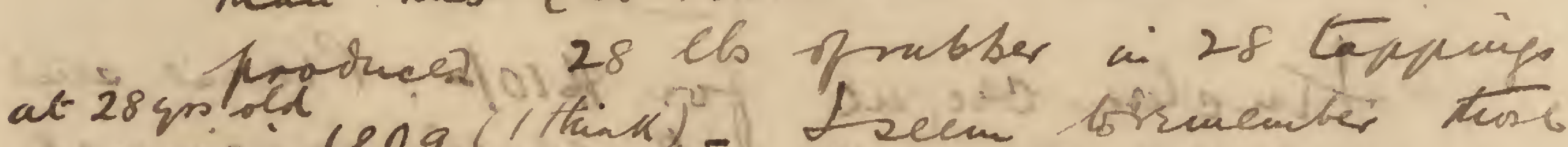

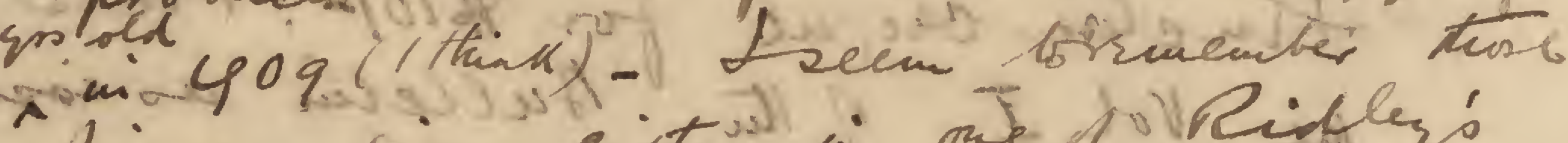

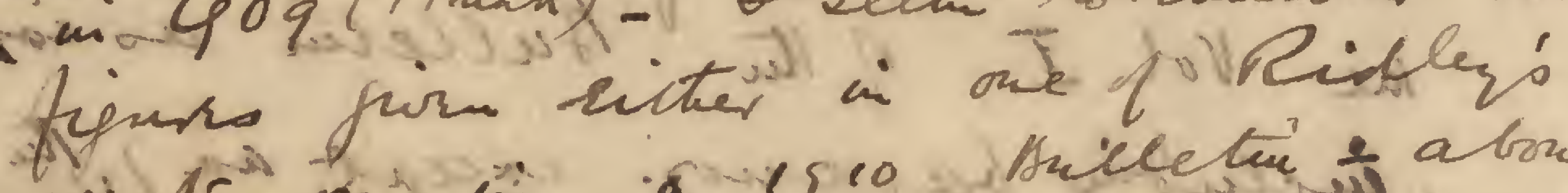

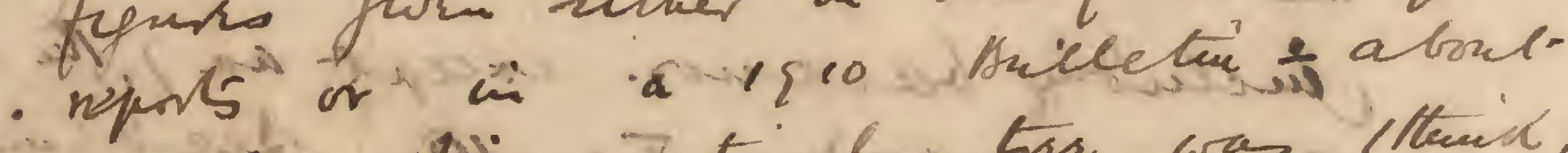

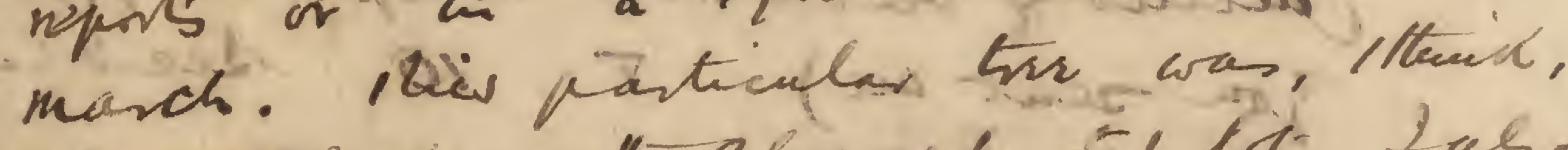

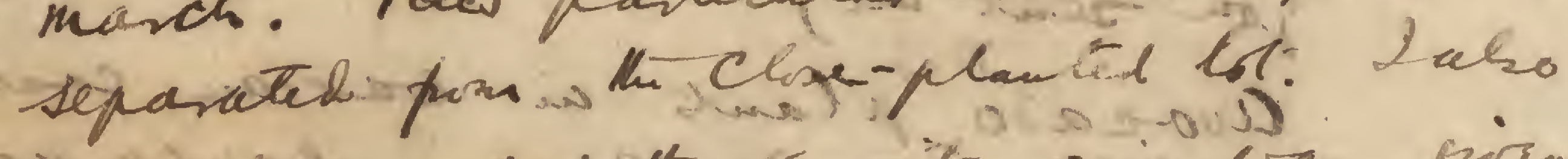
feem. Trumember that its zye ar give

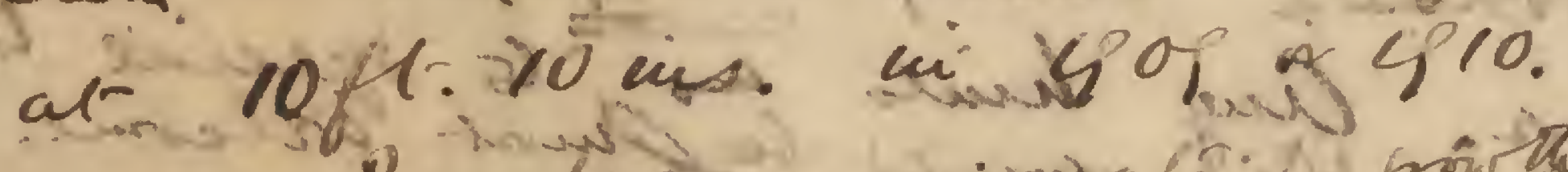

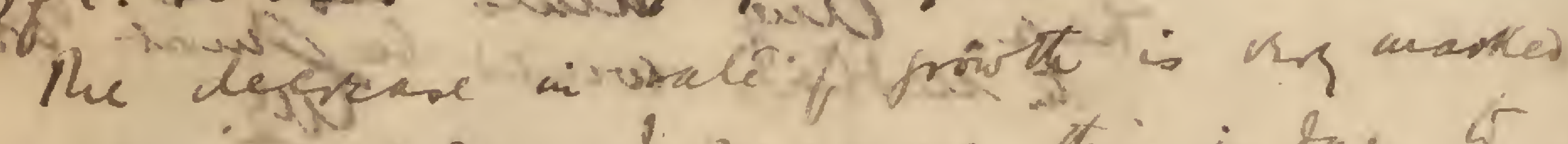
in the cape IN No2. I-zuppose this is hee to

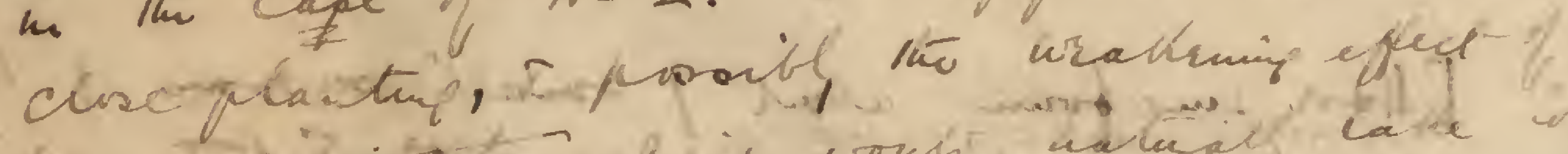

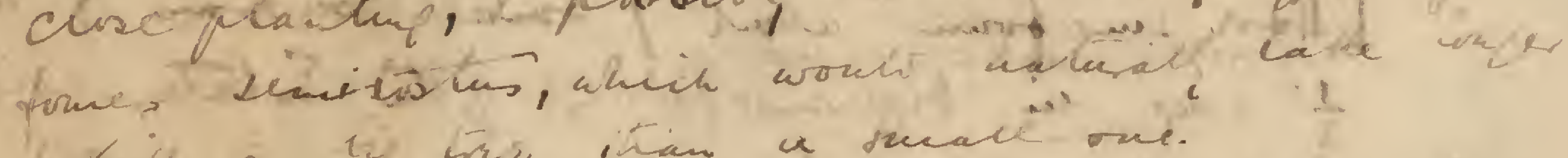

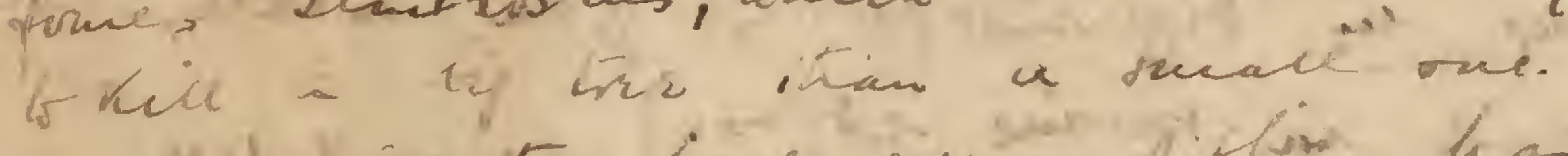

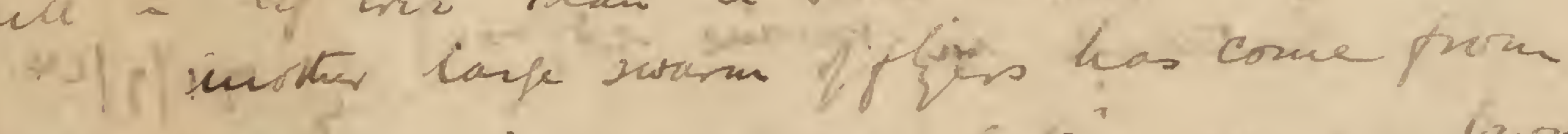

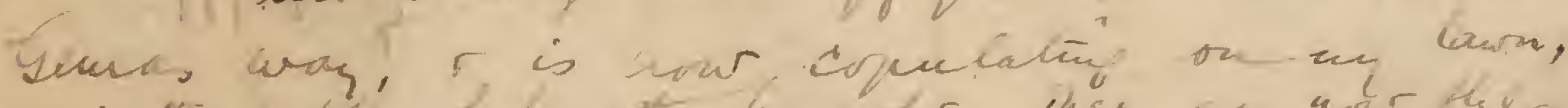

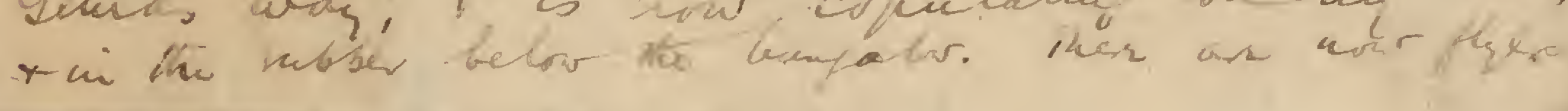


and hoppro simeltaneonal at Sukit Patus. The fligers are apparmet the suniors of thewarm which provice the hopquers, as thy are fow in monber o har keen contionous va the frownd saice thy fint wint then 10 or 11 arens alo. Then

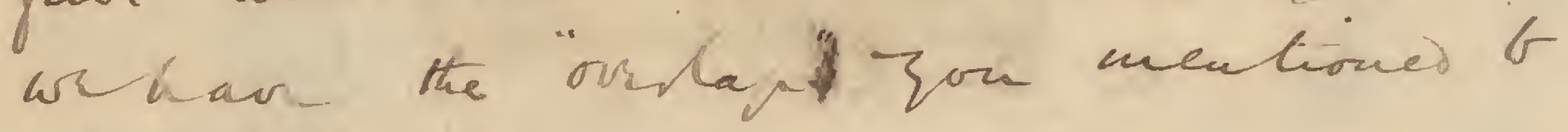
me hes also.

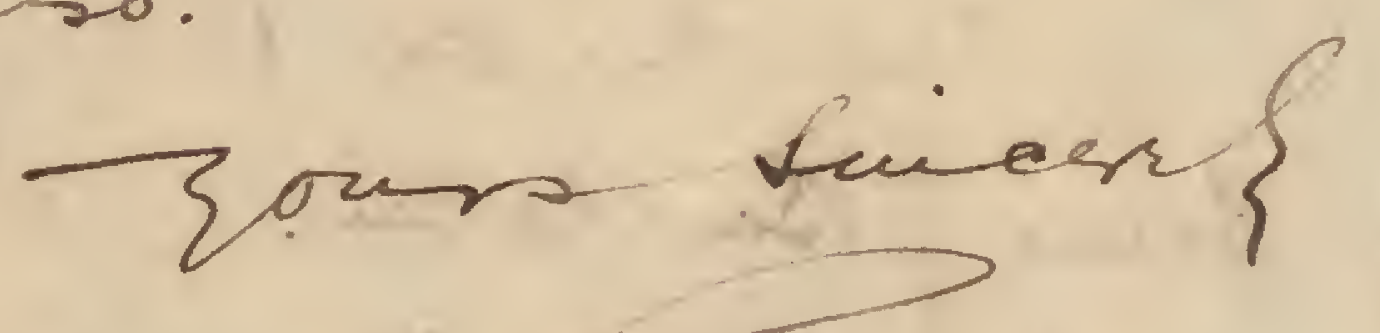

Costiaturas.

Tinclose cheque for \$10/. Please zent

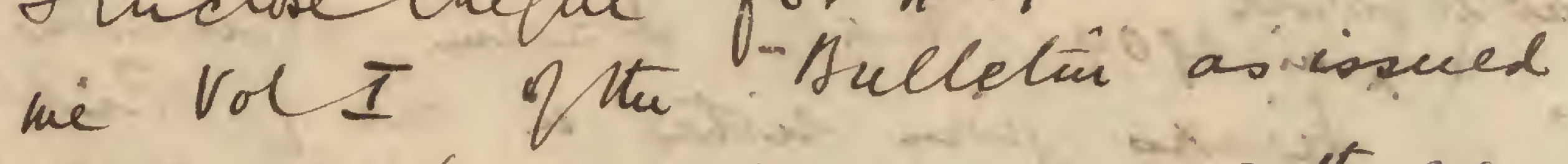
incluting backurs. ixcept as.) the one Zon sentac) $\Gamma$ 10 Seedlin Cracado,filans ai brarican case absissed Teboup Siding, fright pagable

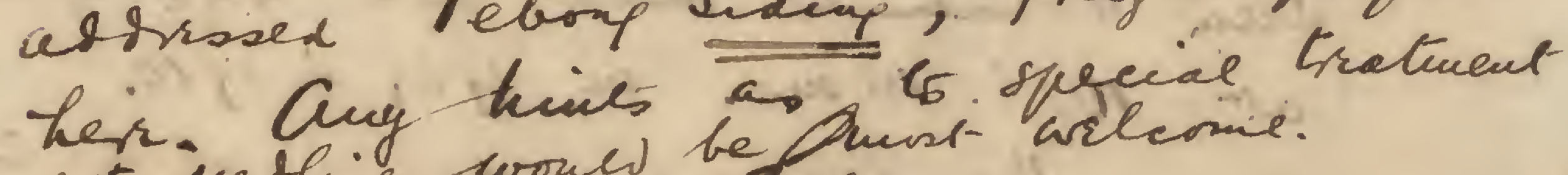

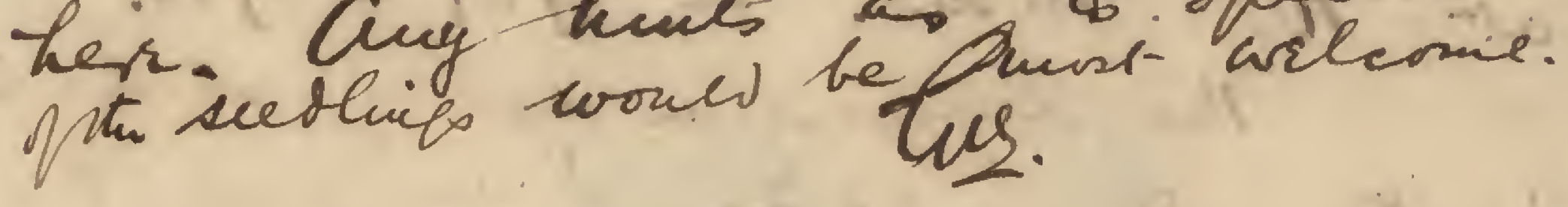

[How smafoum abut 7 smake swarms of hopqes

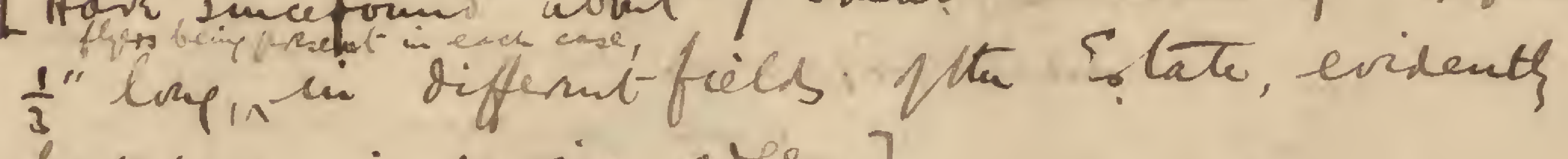
hatekes in ravine etges.] 
L. $0.790 / 14$.

$$
\text { Malacea, } 17 \text { s u } x \text {, } 191 \text {. }
$$

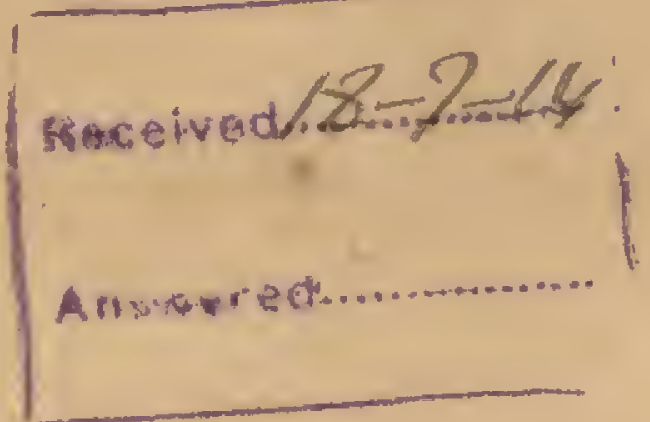

sir,

I have the honour to omelose as requested

a Ilst showixe wiereabouts of locuets in Contral Distrieti, Malacea, during tho wook 5 til to 12 th July.

The facto as shewn in tia list wore subuitited

by the ponginlus of the various ilstriets.Nine Ponghulus

hare not furnished over nil roturns, and tins I take to neas

that so locusts wore observed in their whims euring this

week. Should they report that locusts bave boen seen, I will

sene a further 11st roinforeing this one.

2. I ayself obeorved a sma11 Rigit of locusts at Bed wile, Balok panjang at about $2.30 \mathrm{p}$. m. on 7 tie juily by road side.

3. I do not think any of the swarms observed were laree ones, The word "gleaty" in the 1ist, eoming fron pengiulus, is not a satisfactory indieation of quintity, I an apraid.

I iave the honutur to be,

sir,

your obodient servant,

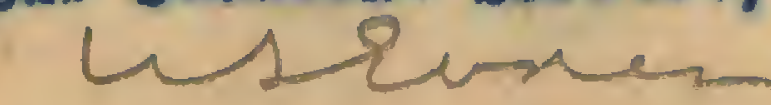

Dy, Collector of Lagd Revoliue.

J. H. Burki111 Esq.,

Dirostor, Botanical flardsms 
Retirn of all swarms of locusts in Central Nietrict fiom $5^{\text {th }}$ to $12^{\text {2l }}$ of luly 1914

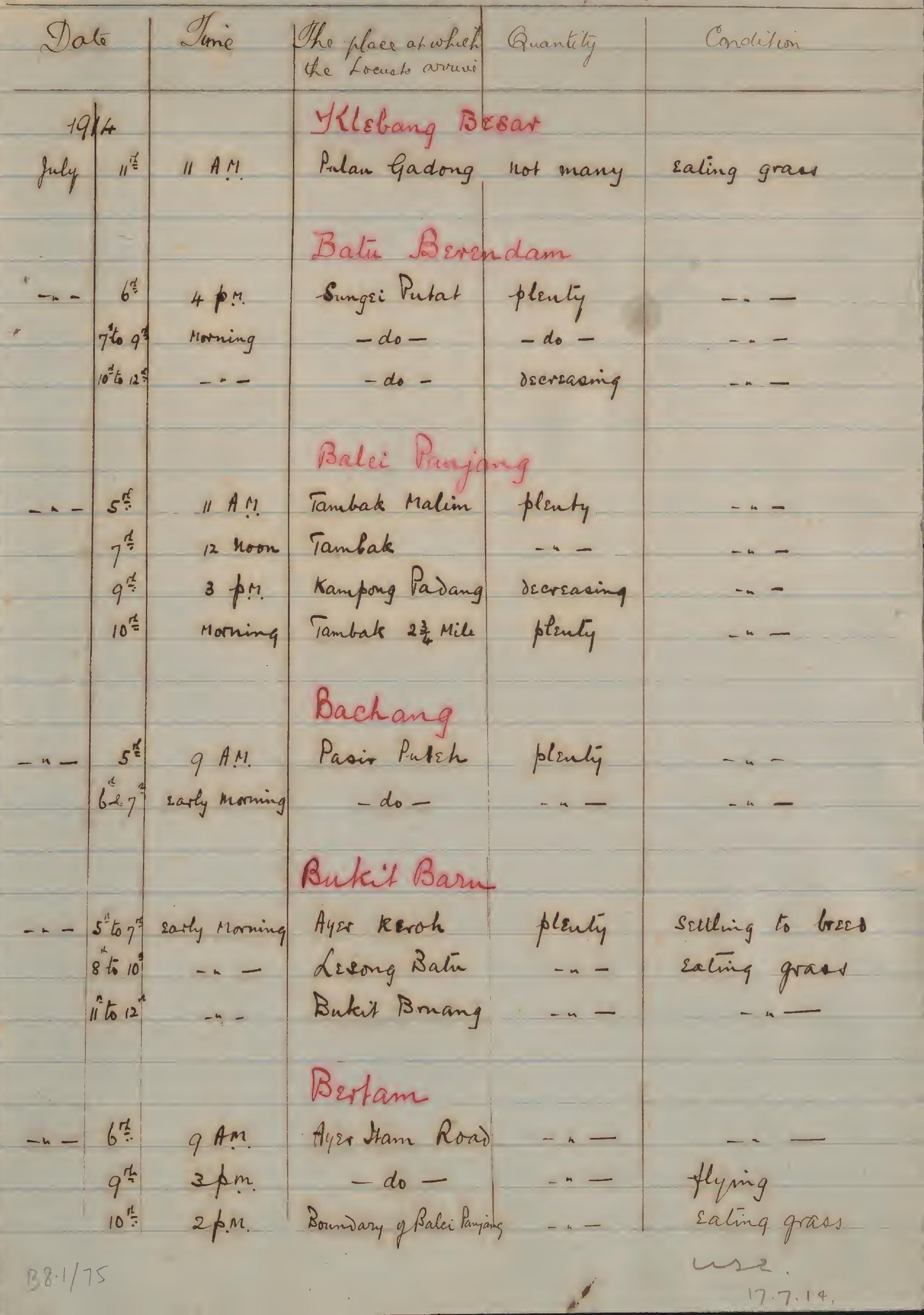


Memorandum.

From

To

$$
\text { From } \frac{\operatorname{Ag} D \sigma_{7}}{-\frac{\operatorname{lig} 17^{5}}{2} 1914}
$$

Director of Eudans Simapie

Daar $\Gamma$ r Bunkill

Answered

Jsend benenite a refort on the

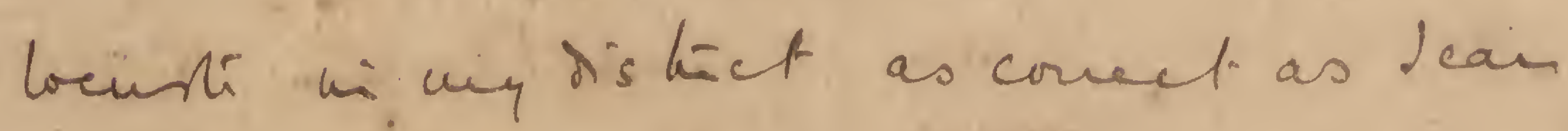
mair it at the momeint.

of comse the masementr of the fliars is so suboan that wo hat can be correctitor love. Rint of the surarus thas seen 
thobt misef - all mitact sxceft. Batany Nalacea Chohme Tombe:

1 han not been ableyt to flaice the Swarn zon mentiones at 15 mile Mulaced Jasia Roat.

pus sivenely

O. 1 Rab 


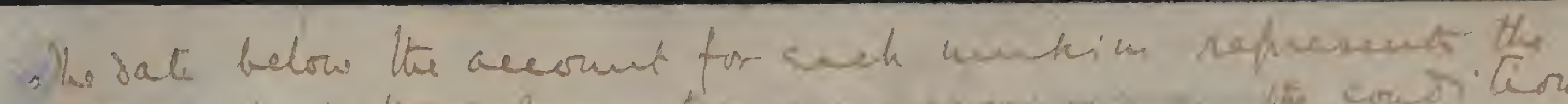

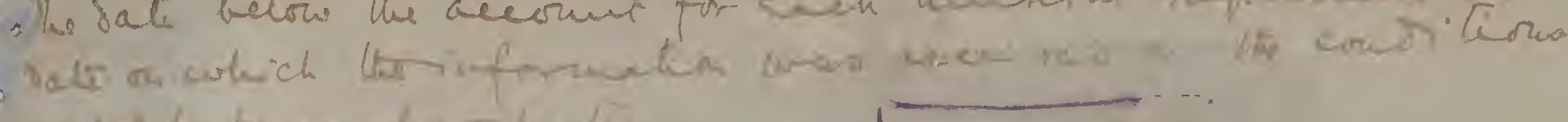

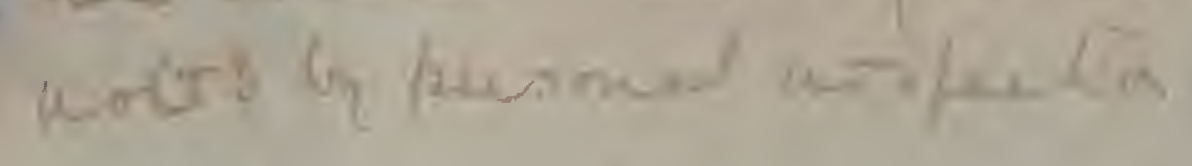

Marliken.

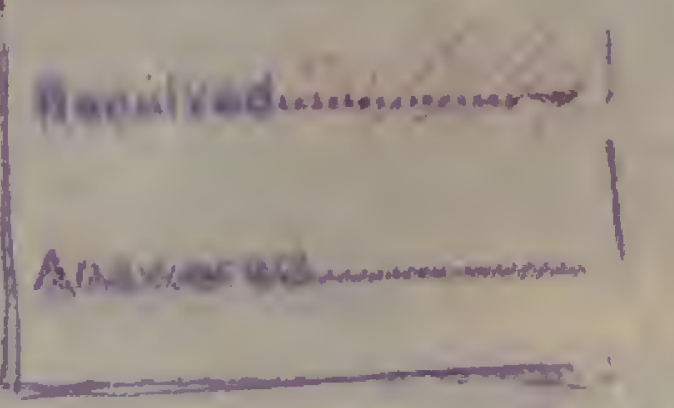

$\left.\begin{array}{l}\text { 1. Round Sungi Reugek Dishict } \\ \text { 3. Near is M Rermatang Feluk }\end{array}\right\}$ all

$q^{1.11 .14}$.

Sabaln

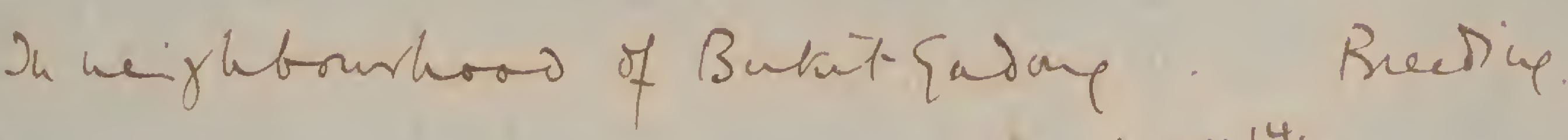
6. v11. 14 .

Sunger Rauble:

Near Parit Rerawas

Befinme to heed.

q. vil' 14 .

Kesang

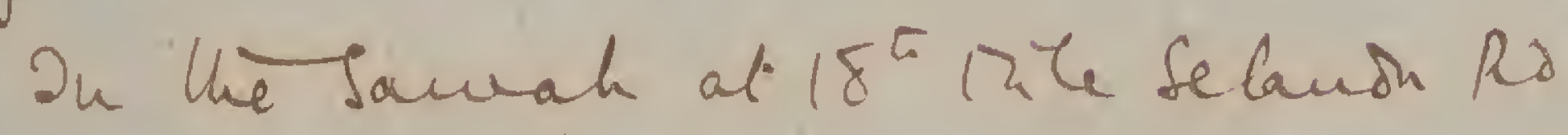

14.211 .14

choling.

Hoppers at $25 \frac{1}{2}$ unte.

dasin

None

17. vil $^{14}$

Rin.

$58 \cdot 1 / 77$

Nowe 
Ayar Panas.

tone

$$
13 \cdot 11.14 .
$$

ryalas

rery lage numbers of to th thies hofpers.

Esperially at $30 \frac{1}{2} M$ lage

gnowtic of betpers

Jus.

Mone

13.

Chin Chin.

Lage numbers of boffew 7317 .
Sarkam.

Swarm of flians just antivo Not hesd yn in the savah at the $11 \frac{1}{4} \Pi$.

$$
13 \cdot \sqrt{11} \cdot 14 \text {. }
$$

Chabac.

Lage numbers of bof fer at $2314+29 \frac{1}{2} M$. 15 it $14=14$.

Secuftang

kery lage suarm of ftians in Sawak $13 \frac{1}{4} 7$ iton othor sige of rad.

ju sowath thaces onth

Some recting 16.011 .14 .

Texong.

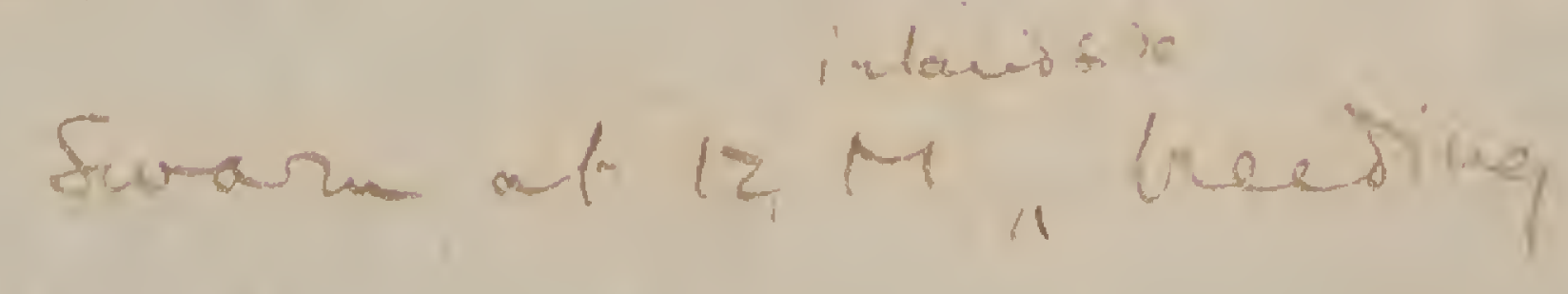

Unbes

Two swarues of theis

(Norefart prom iame as to heopy or ust) 16.wh-14 
Batang Malaka.

Surarm of bofpers $29 \frac{1}{2}$ he.

$$
17^{.211 .14 .}
$$

Bubit Lingsch

None

$17.011 \%$.

Selountor

Prome

$17 \times 11.4$ 


\section{Official Memorandum.}
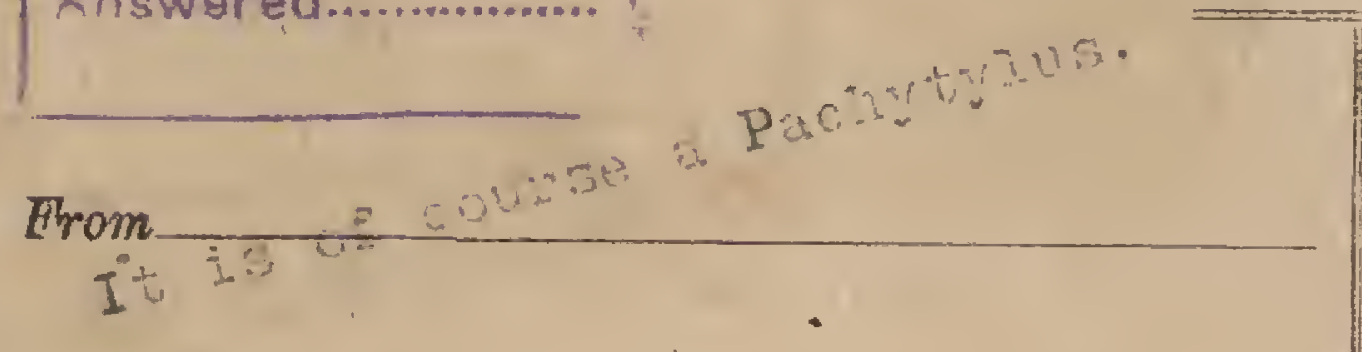

To_. Dear Burleis.

11tin Ju: 1924.

Tie Autucities in Sunatra huve beth consutec severai tires and

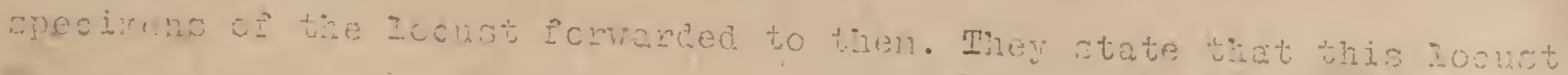

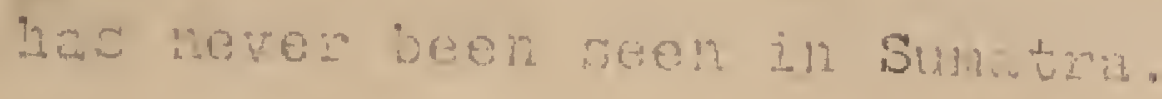

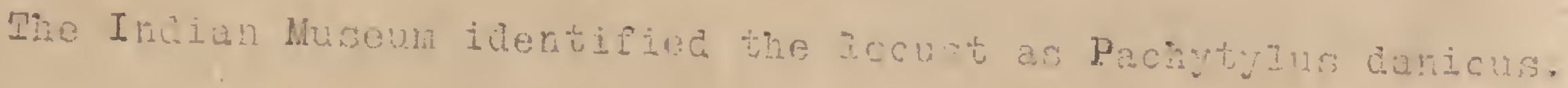

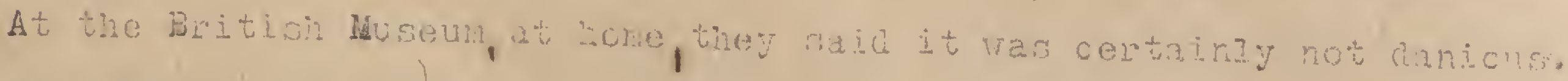

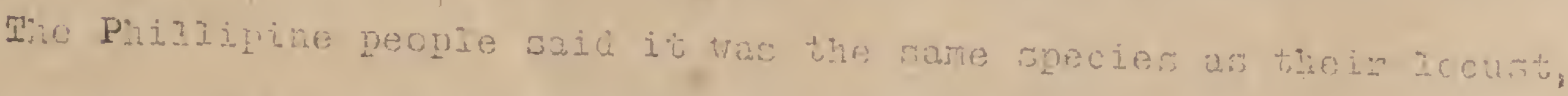

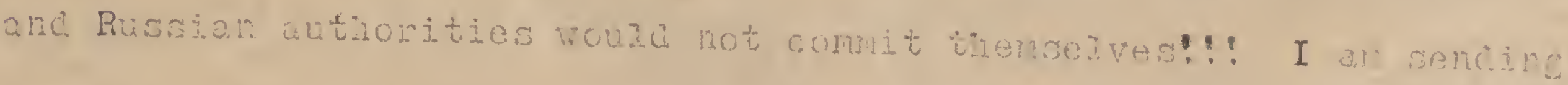

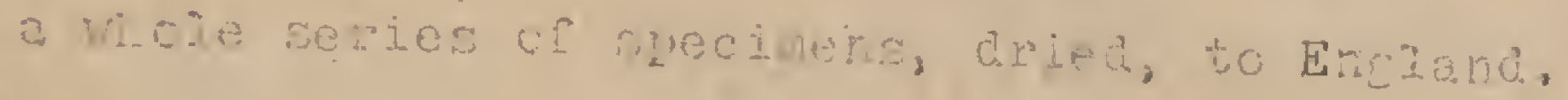


Teboug.

2 suraras hoppero (very young - less Nown $\frac{1}{2}$ "Cong) ins

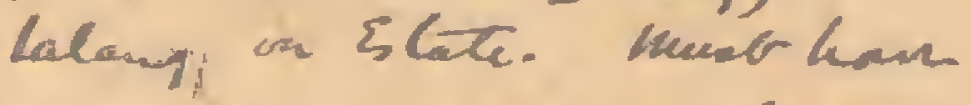
been born close at havid. The fint flyers here tor tegan tefits ro arres apo. Tuive of cicabationi mont har bee. les than qareks. Regelen been a cartini unuter of thers colizendy for tita cawrik, rotture th mincinsun of micubatin

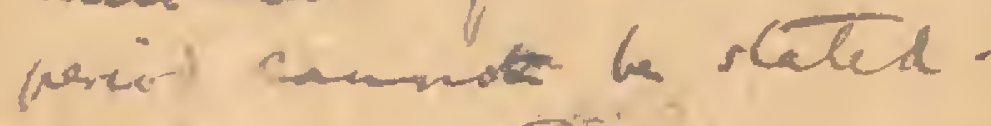

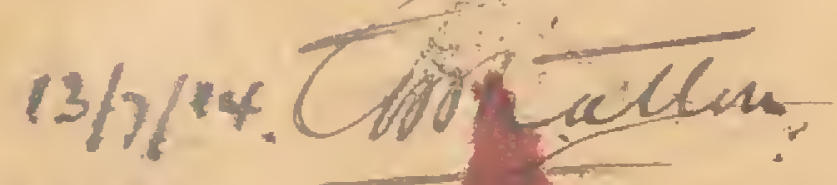




\section{POST CARD}

FEDERATED MALAY STATES

THE ADDRESS ONLY TO BE WRITTEN ON THIS SIDE
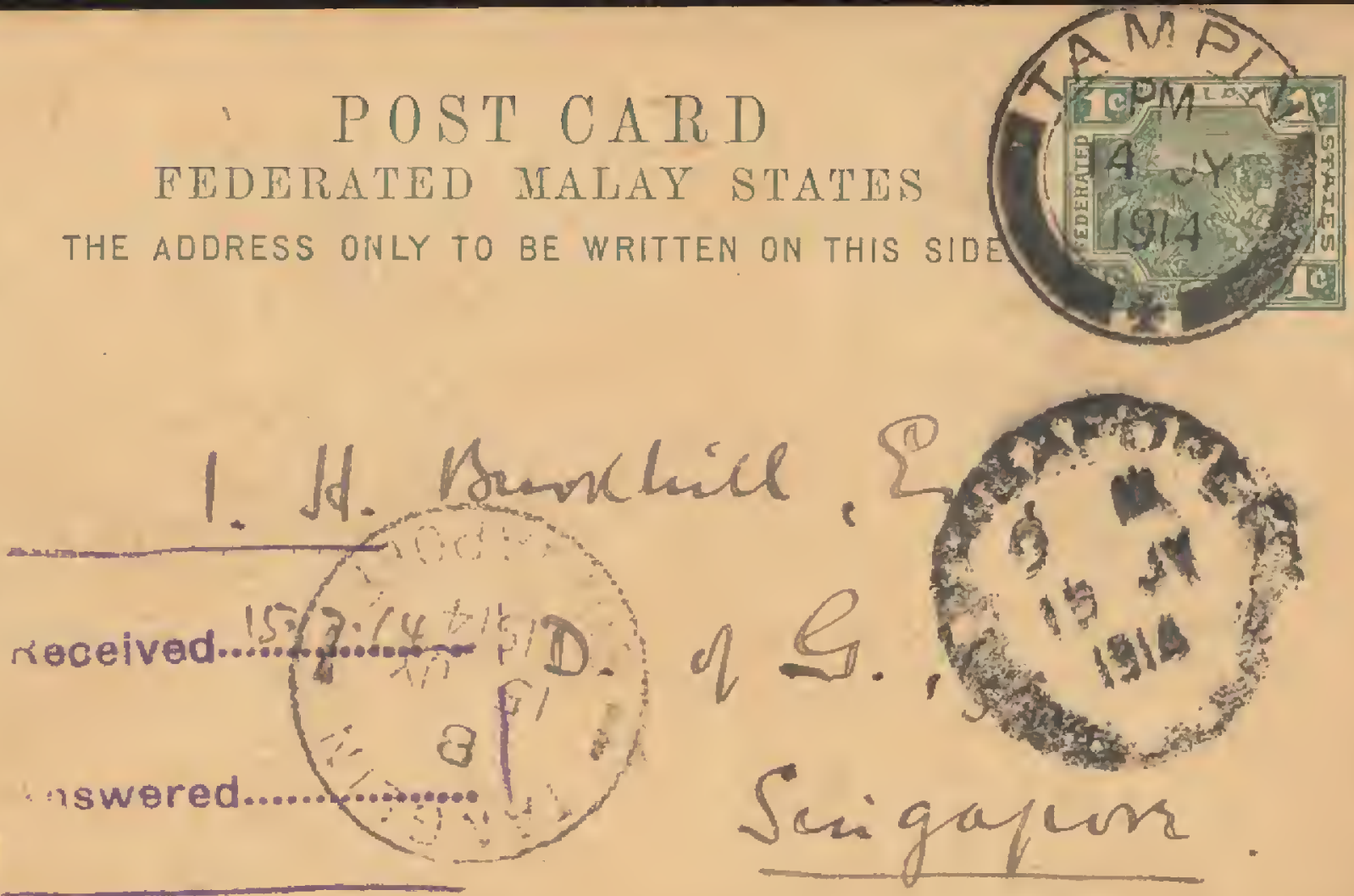


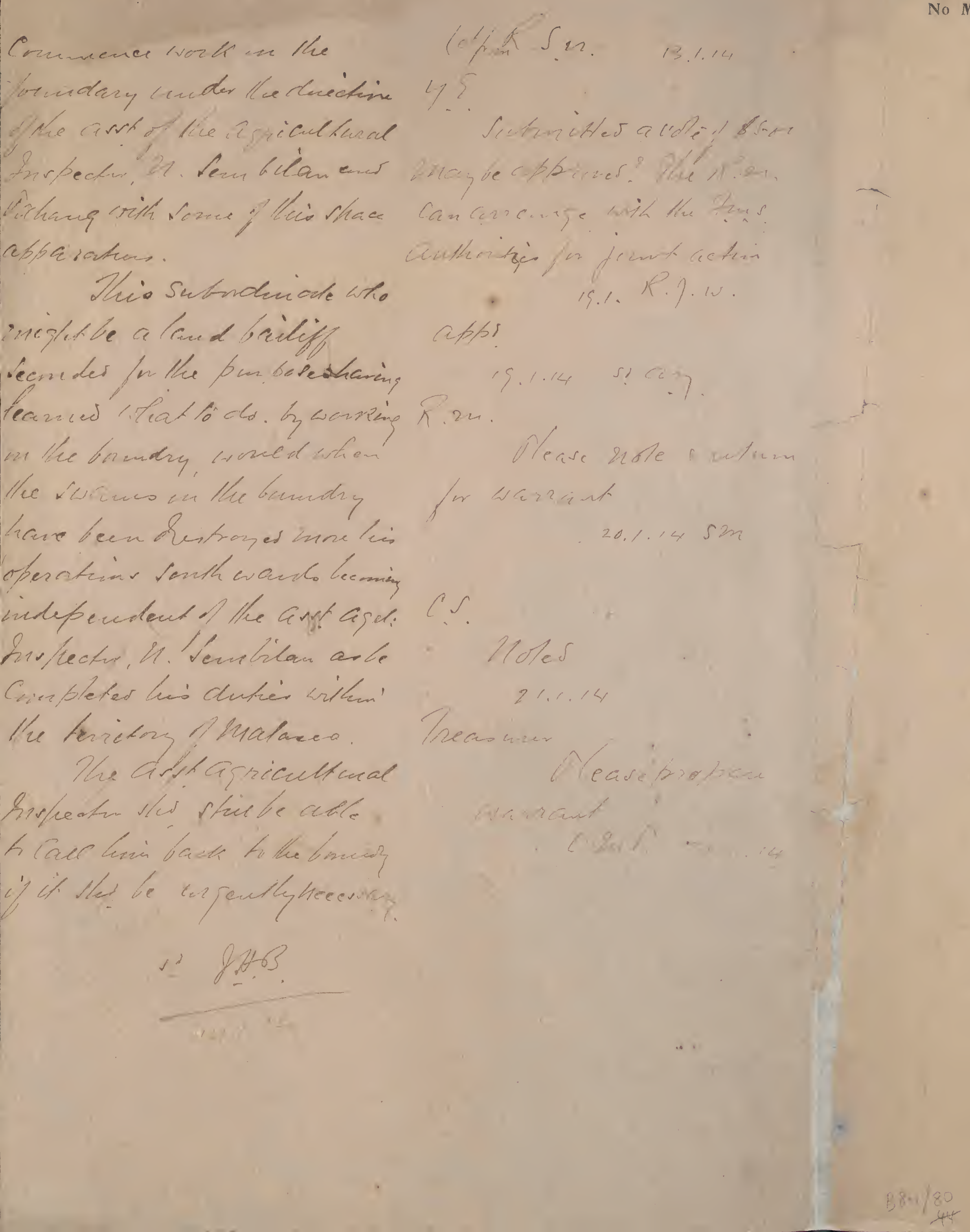
Minutes should be written on this page.
to be used if required.

A separate half $=$ sheet 


\section{West Disinfecting Company}

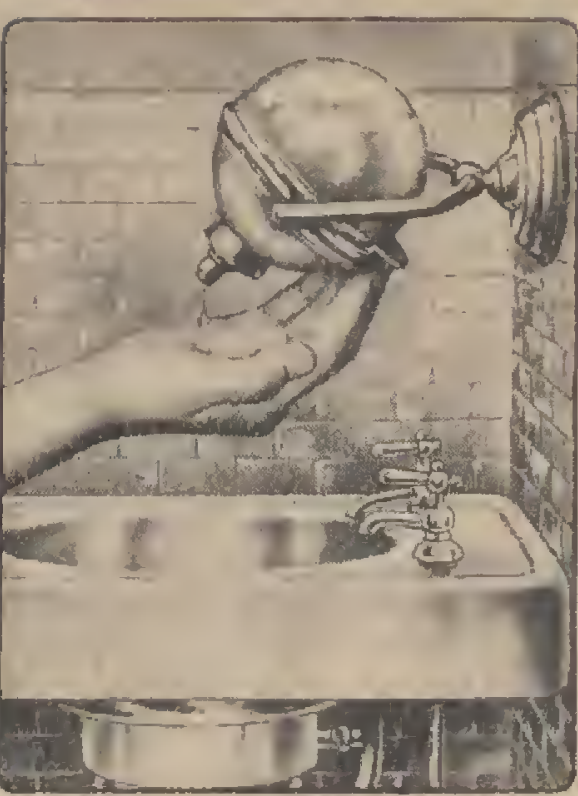

LIQUID SOAP and DISPENSERS

MANUFACTURING CHEMISTS

Disinfectants and Sanitary Appliances

EXECUTIVE OFFICES. 2 EAST 42 D ST.

New Yorks, February 10, 1915.

Bureau of Agriculture,

Govornment of the Straits settlemonts,

Singapore, Straits Settlements.

Gentlemen: :

V.e take the liberty to address you and direct your attention to the enclosed copy of a letter which we have just received from the Covernment of the Philippine Islands.

This letter deals with the question of the locust pests in that country and hem ffictenty our product, CORO-NOLEUM, rids the fields of both the locust and the hopper, when used in a $1 \%$ solution. A galion of CORONOLEUM costs abnut 1.00 gold, frea deliver, to jcur country, provided no duty has to be paid. As this product is lised one gallnn of CORO-NOInUB to 100 gallons if water, fir the above mentirned purpoee, the solution costs you just If per galion or $\frac{1}{2} 2$ per liter.

CORO-NOLFUM is uued not only as an insecticide but it is primarily important as a high class dininfectant and heads the Iist of cur special pro. ducts. "This product ha" been tested by the Uniterl States Government ard we are supplying cur Governmert ard many rthers. In Bulletin No. 82 of tha United Status Public Health Service, crpy oi wich we are sending you undir separat enver, on Pags 43, you will find that Chloro-Naptholeum; nuw called CORO-NOLEUA, is 5 to 6 times morg efficient bacteriologibally than pure Carbolic Acid when tested againct a vigorcus culture of Bacillus Typhnsus.

Fe therefore, feol that it would be to the advantage of ycur Government to inmouce his prcduct in hospitels, barracks and similar institutions where sanitary conditins are of uppermost importance.

Te are al:o sending gou a copg of our catajogue which will. give you an idea of the general line of products which we manufecture, and should you desire any further infurmation in regard to any of these products, we shall be glad to have you advise us.

Plicing cur services at your command, we are,

$R, 8 \cdot 1 / 81$

Enc. 1 letter

Under Cover 1 bulletin

1 catalogue
Yours very respectfully, WEST DISINETCTNG COMPANY

Vice $\rightarrow$ Prosident 
THE GOVERNMENT OF THE PHILIPPINE ISLANDS

DEPARTMENT OF PUBLIC INSTRUCTION

BUREAU OF AGRICULTURE

Str:

Wanila, December 10, 1914.

I have the honcr to acknowledge receipt of samples of jour insecti-

cides and germicides.

As previously stated, cur office is desirous of obtaining a compound

that may be utilized as a contact insecticide against locust in the nymph

(hopper) stage. To this end, I have tried out in a small ray the samples of

Coro-Noleum. While the magnitude of this experiment makes it impossible to state definitely its value under actual field conditions, such as obtain in the uninhabited lands, yet I believe that, from what I have seen, we can uti-

lize it successfuIly in destroying this pest. As you are eware, the tost made was conducted upon the fifth instar hoppers almost, ready to take wing, which are, of course, more resistant than the younger, ones to an insecticide. In view of the results obtainod in this trial. I have placed a requisition for one hundred gallons of Coro-Noleum, which amount should furnish enough material to determine the exact value of the same as locusticide. Should opportunity offer. I will also test it out on such other pests as are brought to the attention of this office. Upon completion of our experiments, should the same be desired by ycu, I will be pleased to furnish you with a copy of the resuIts obtained.

Verg respectfully,

(SD.) D. B. Mackio

Mr. Julius Norden, Entomologist.

The West Disinfecting Co.,

New York, N. Y.. U. S. A. 


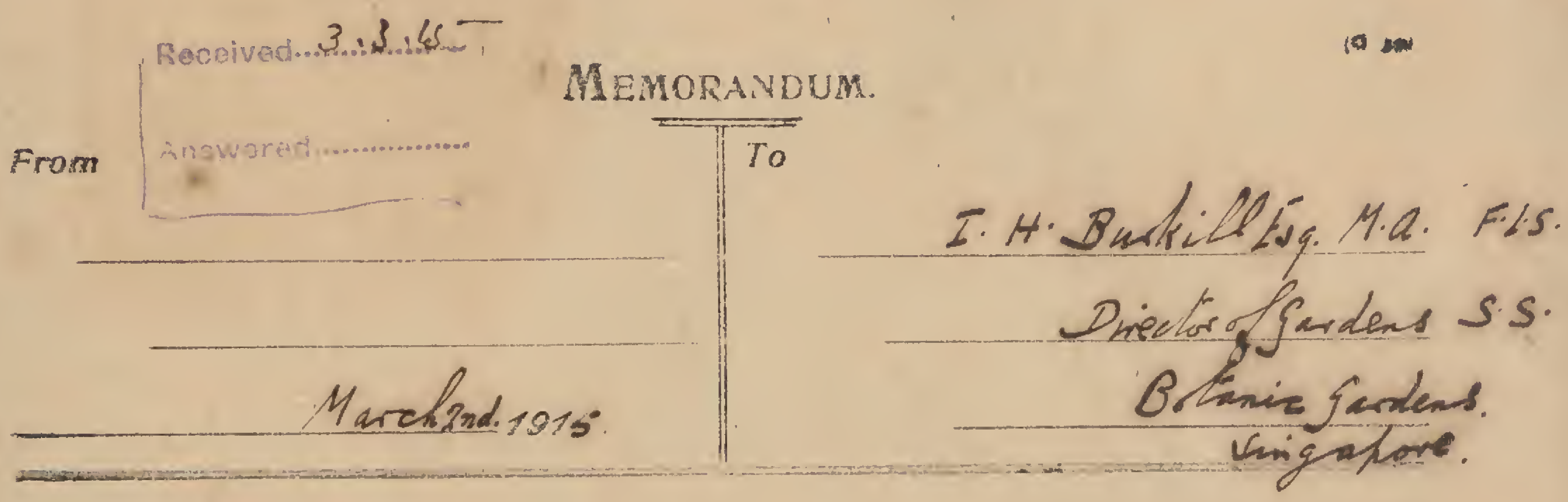

Wear M. Burtill,

- Last worde you on Fébunary 19:.

H thers, small blacto objects, have atheared is day at thee Lhaces, all of whil thaces an is tha bulity Thisin.

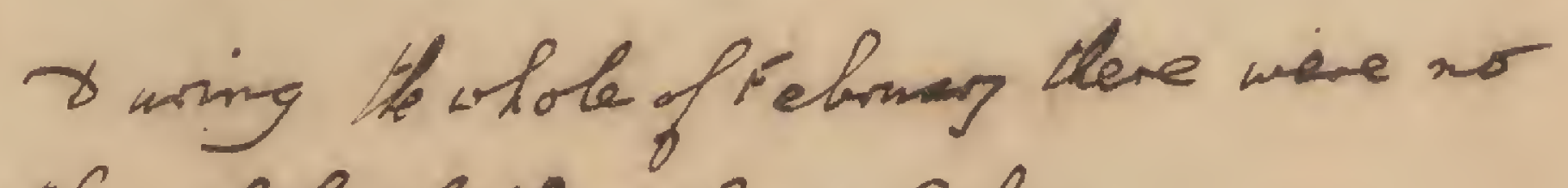
Hothers in the whok of to Maleacabolomy.

- shall wite again when th have ghuthes

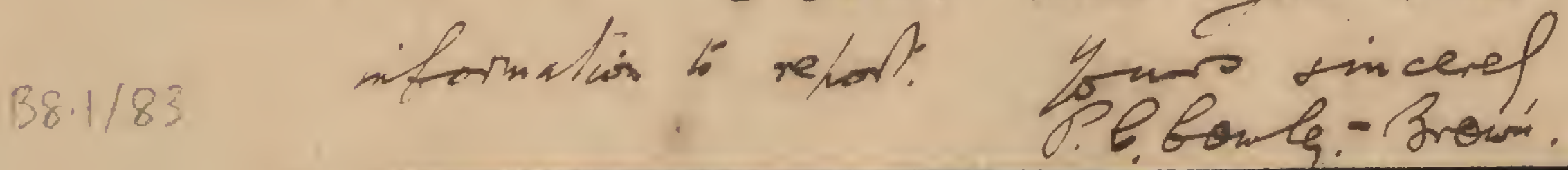


Dotanta Gardan,

Singarorea

7orth, Jamary, 7075

Barr Mr. Miehen?,

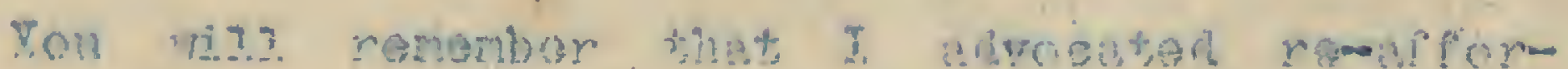

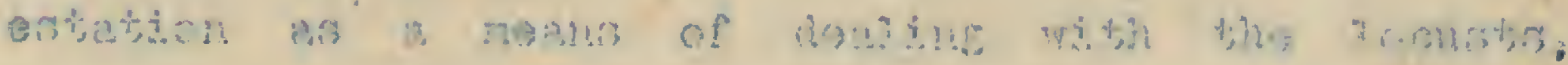

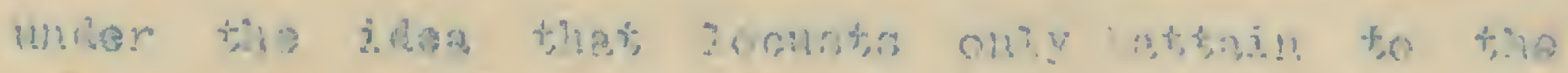

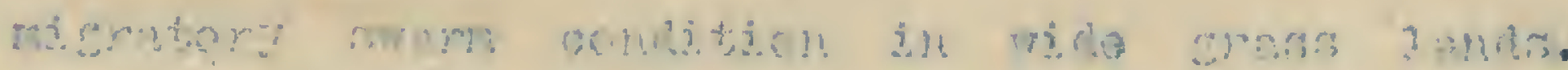

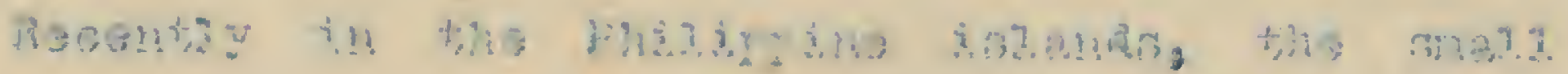

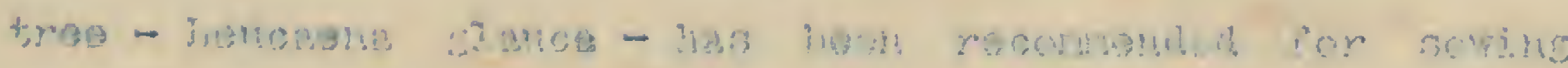

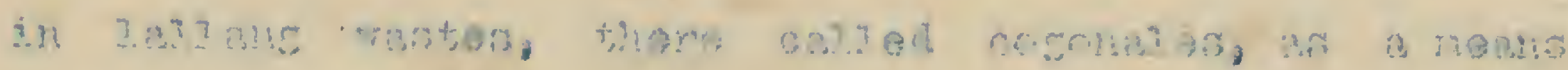

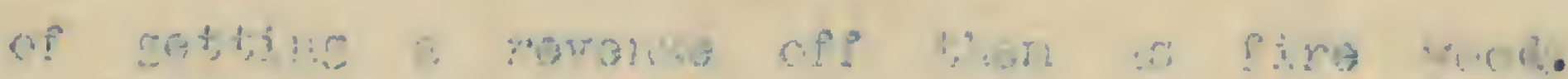

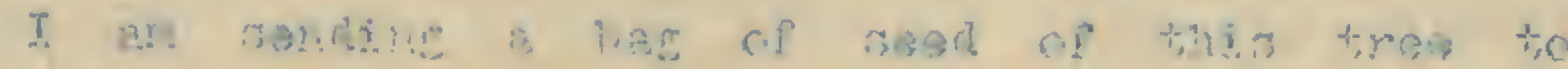

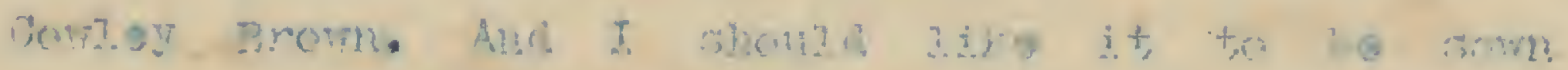

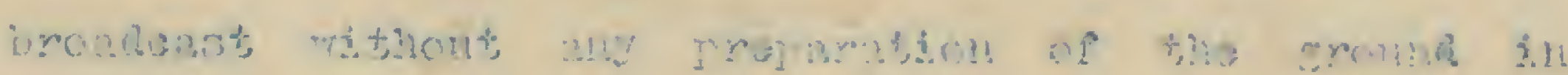

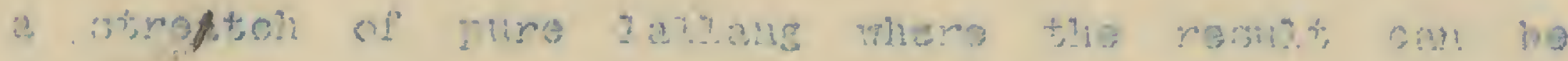

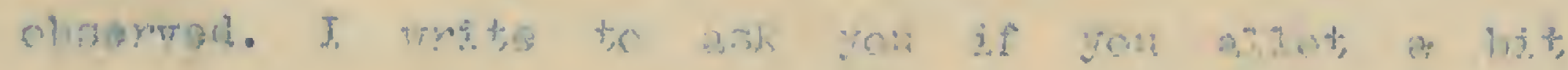

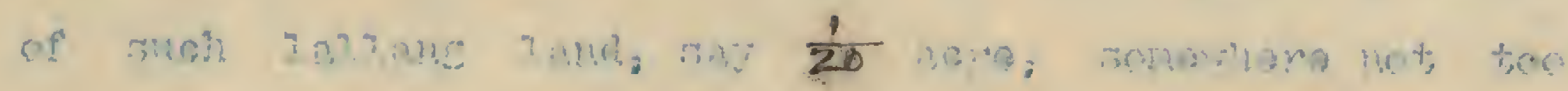

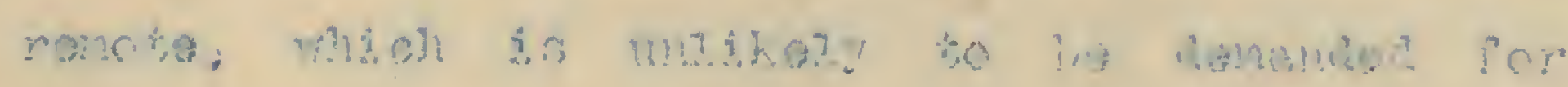

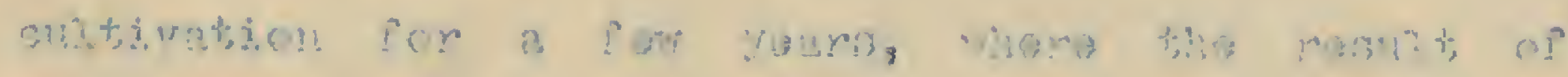

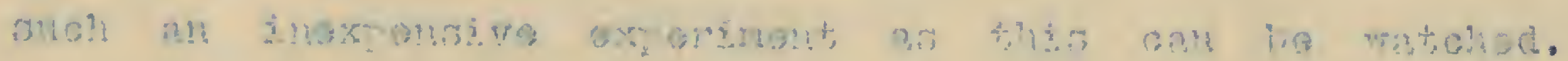

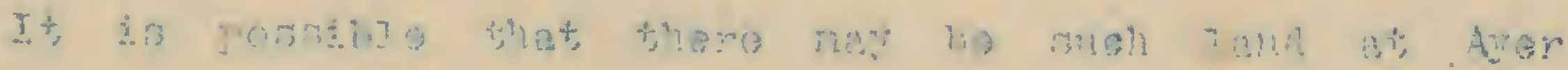

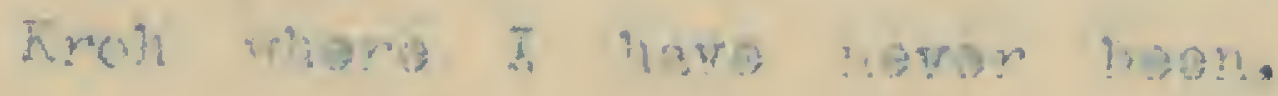

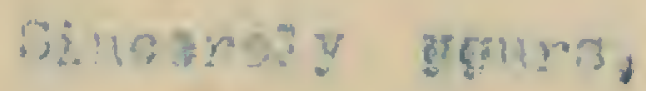

Sichad (J.Henry Burkir?)

Desi Gom?ay Jrewn,

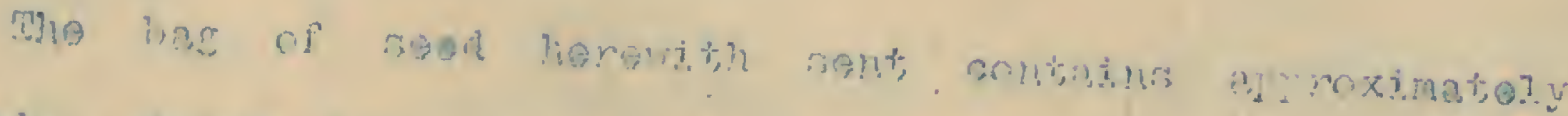

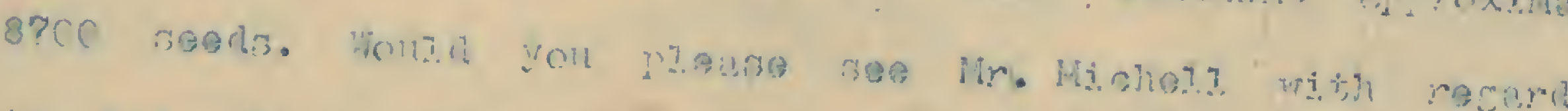
$88 \cdot 1 / 84$

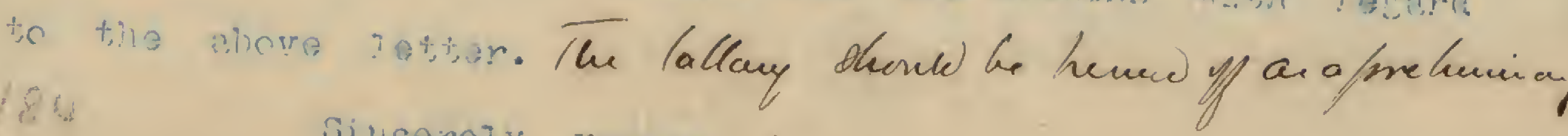
nincorary Ponras 
Receiveci25.\%./1s.

Memorandum

From

To
- H:Bustillsig. 4. a: Fi.s.

Directo f fardent. S.S.

Botanic Gardexs.

Feborary 18 titis

aigafore.

Deas M. Bublith,

So for this mants mo thefhes lave atheared.

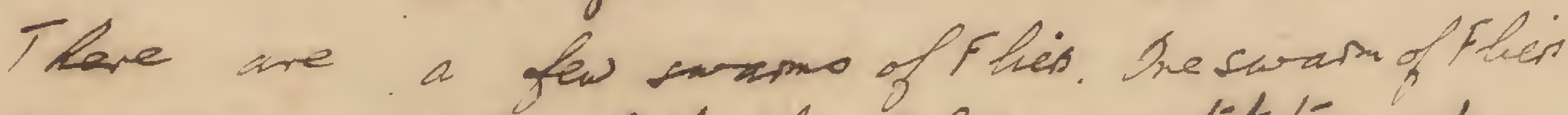
is young and It thits the fheis canstituting it must have been bred in some flen stace surrom ded by jingte

I hope the "Imente" - as the Lapers callit -

$B 8.1 / 85$

Po. Goulf - Inow. 